\title{
Conceptual Ecological Models to Support Detection of Ecological Change on Alaska National Wildlife Refuges
}

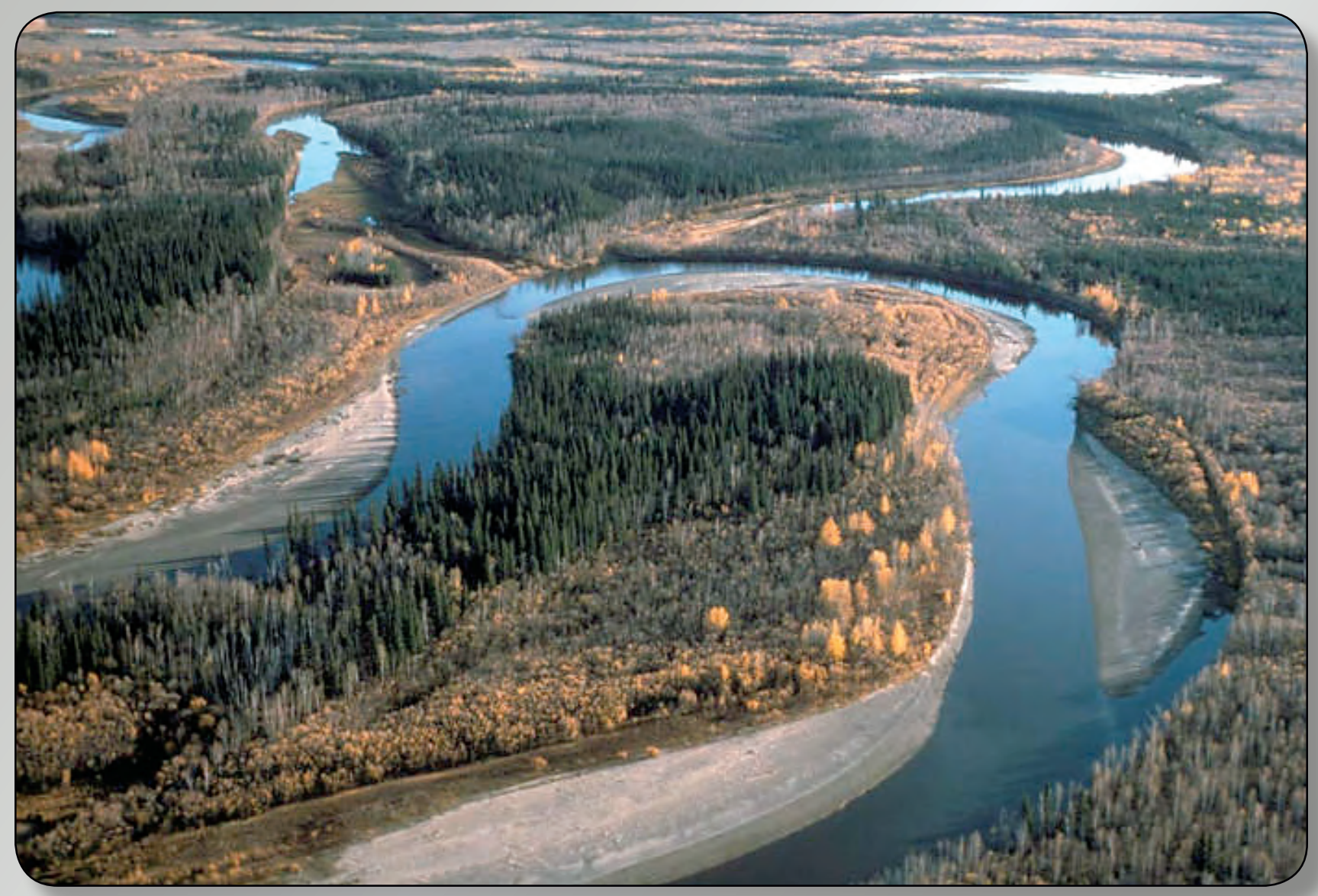

Open-File Report 2011-1085 
Cover: Photograph showing Yukon Flats River and Oxbows, Yukon Flats National Wildlife Refuge, Alaska (from U.S. Fish and Wildlife Service). 


\section{Conceptual Ecological Models to Support Detection of Ecological Change on Alaska National Wildlife Refuges}

By Andrea Woodward and Erik A. Beever

Open-File Report 2011-1085 


\title{
U.S. Department of the Interior \\ KEN SALAZAR, Secretary \\ U.S. Geological Survey \\ Marcia K. McNutt, Director
}

\author{
U.S. Geological Survey, Reston, Virginia: 2011
}

For more information on the USGS - the Federal source for science about the Earth, its natural and living resources, natural hazards, and the environment, visit http://www.usgs.gov or call 1-888-ASK-USGS.

For an overview of USGS information products, including maps, imagery, and publications, visit http://www.usgs.gov/pubprod

To order this and other USGS information products, visit http://store.usgs.gov

Any use of trade, product, or firm names is for descriptive purposes only and does not imply endorsement by the U.S. Government.

Although this report is in the public domain, permission must be secured from the individual copyright owners to reproduce any copyrighted materials contained within this report.

Suggested citation:

Woodward, Andrea, and Beever, E.A., 2011, Conceptual ecological models to support detection of ecological change on Alaska National Wildlife Refuges: U.S. Geological Survey Open-File Report 2011-1085, 136 p. 


\section{Contents}

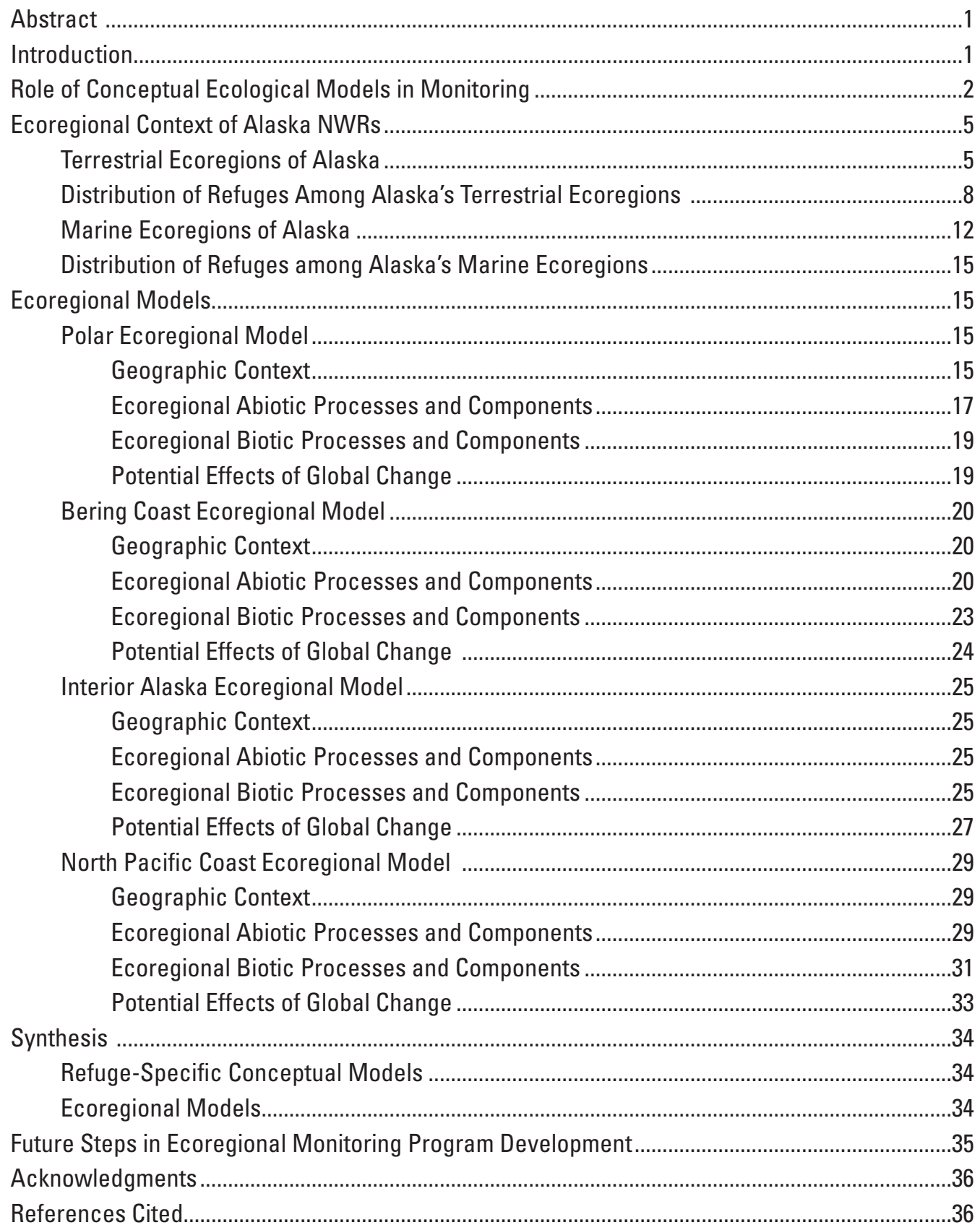




\section{Contents-Continued}

Appendix 1. Comparisons Between Ecoregional Classifications and Landscape Conservation Cooperatives

Appendix 2. Polar Ecoregion-Arctic National Wildlife Refuge ...................................................51

Appendix 3. Bering Coast Ecoregion-Togiak, Yukon Delta, and Selawik National

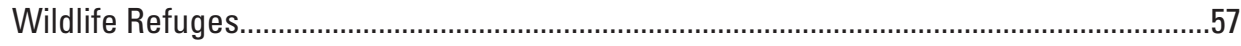

Appendix 4. Interior Alaska Ecoregion_-Innoko National Wildlife Refuge ....................................61

Appendix 5. Interior Alaska Ecoregion-Kanuti National Wildlife Refuge ...................................67

Appendix 6. Interior Alaska Ecoregion-Kenai National Wildlife Refuge ...................................73

Appendix 7. Interior Alaska Ecoregion-Koyukuk, Nowitna and Northern Innoko

National Wildlife Refuges .79

Appendix 8. Interior Alaska Ecoregion—Selawik National Wildlife Refuge ..................................83

Appendix 9. Interior Alaska Ecoregion-Tetlin National Wildlife Refuge........................................87

Appendix 10. Interior Alaska Ecoregion_Yukon Flats National Wildlife Refuge ...........................93

Appendix 11. North Pacific Coast Ecoregion-Alaska Maritime National Wildlife Refuge ..........99

Appendix 12. North Pacific Coast Ecoregion-Alaska Peninsula and Becharof National Wildlife Refuges. .103

Appendix 13. North Pacific Coast Ecoregion_-lzembek National Wildlife Refuge .......................109

Appendix 14. North Pacific Coast Ecoregion-Kodiak National Wildlife Refuge........................119

Appendix 15. Beaufort_Chukchi Seas Marine Model ..............................................................125

Appendix 16. Bering Sea Marine Model ............................................................................................129

Appendix 17. North Pacific Sea Marine Model ..........................................................................133 


\section{Figures}

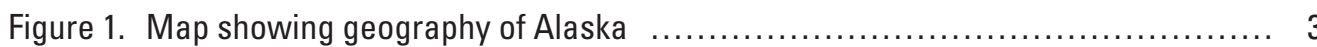

Figure 2. Map showing boundaries of National Wildlife Refuges within Alaska, in relation to the 32 unified ecoregions of Alaska ............................. 6

Figure 3. Diagram showing eight Level-1 groups of the 32 unified ecoregions defined by Nowacki and others (2002)

Figure 4. Diagram showing relationship between the eight Level-1 groups and the ecoregions used in this report

Figure 5. Map showing boundaries of Alaska National Wildlife Refuges relative to the four ecoregions used in this report

Figure 6. Map showing relationship among four federal jurisdictions and mountainous areas across Alaska illustrating that USFWS lands lend to be at low elevations, NPS and U.S. Forest Service lands tend to be in mountainous areas, and BLM lands are mixed

Figure 7. Map showing Marine ecoregions of Alaska ............................... 13

Figure 8. Map showing Pelagic Bird Conservation Regions surrounding Alaska............ 14

Figure 9. Map showing conceptual model of Polar Ecoregion illustrating resources and processes that operate at spatial scales larger than individual refuges

Figure 10. Map showing conceptual model of the Bering Coast Ecoregion, illustrating resources and processes that operate at spatial scales larger than individual refuges

Figure 11. Map showing conceptual model of the Interior Alaska Ecoregion, illustrating resources and processes that operate at spatial scales larger than individual refuges

Figure12. Map showing conceptual model of the North Pacific Coast Ecoregion illustrating ecological processes and components that operate at scales larger than individual refuges 


\section{Tables}

Table 1. Percentages of each Alaska National Wildlife Refuges in Polar, Bering Coast, Interior Alaska, and North Pacific Coast terrestrial ecoregions ................ 12

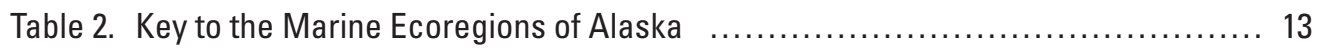

Table 3. Wildlife refuges, land-management units of other agencies, and marine region included in the Polar Ecoregion

Table 4. Summary of elements included in refuge-specific terrestrial models from the Polar Ecoregion and Beaufort-Chukchi Seas marine model, and description of representation of elements in the ecoregional model $\ldots \ldots \ldots \ldots \ldots \ldots \ldots \ldots \ldots 18$

Table 5. Summary of weather statistics for the Polar Ecoregion $\quad \ldots \ldots \ldots \ldots \ldots \ldots \ldots \ldots \ldots$

Table 6. Wildlife refuges, land-management units of other agencies, and marine region in the Bering Coast Ecoregion

Table 7. Summary of elements included in refuge-specific terrestrial models from the Bering Coast Ecoregion and eastern Bering Sea marine model, and description of representation of elements in ecoregional model

Table 8. Summary of weather statistics for the Bering Coast Ecoregion $\quad . . \ldots \ldots \ldots \ldots \ldots . \ldots 23$

Table 9. Wildlife refuges and land-management units of other agencies included in the Interior Alaska Ecoregion

Table 10. Summary of elements included in refuge-specific terrestrial models from the Interior Alaska Ecoregion, and description of representation of elements in ecoregional model.....

Table 11. Summary of weather statistics for the Interior Alaska Ecoregion

Table 12. Wildlife refuges, land-management units of other agencies, and marine region included in the North Pacific Coast Ecoregion

Table 13. Summary of elements included in refuge-specific terrestrial models from the North Pacific Coast Ecoregion and the North Pacific Ocean marine model, and description of representation of elements in ecoregional model 32

Table 14. Summary of weather statistics for the North Pacific Coast Ecoregion 


\title{
List of Acronyms and Symbols
}

\author{
List of Acronyms
}

$\begin{array}{ll}\text { ACC } & \text { Alaska Coastal Current } \\ \text { ANILCA } & \text { Alaska National Interest Lands Conservation Act } \\ \text { ATV } & \text { All-Terrain Vehicle } \\ \text { BCR } & \text { Bird Conservation Region } \\ \text { CCP } & \text { Comprehensive Conservation Plan } \\ \text { DOI } & \text { Department of Interior } \\ \text { I\&M } & \text { Inventory \& Monitoring } \\ \text { IPCC } & \text { Intergovernmental Panel on Climate Change } \\ \text { LCC } & \text { Landscape Conservation Cooperative } \\ \text { LPP } & \text { Land Protection Plan } \\ \text { NDVI } & \text { Normalized Difference Vegetation Index } \\ \text { NEPA } & \text { National Environmental Policy Act } \\ \text { NWR } & \text { National Wildlife Refuge } \\ \text { PDO } & \text { Pacific Decadal Oscillation } \\ \text { SDM } & \text { Structured Decision Making } \\ \text { SSP } & \text { Science Support Partnership } \\ \text { US NABCl } & \text { United States North American Bird Conservation Initiative } \\ \text { USFWS } & \text { U.S. Fish \& Wildlife Service } \\ \text { USGS } & \text { U.S. Geological Survey } \\ \text { WIP } & \text { Wildlife Inventory Plan }\end{array}$

Symbols

\begin{tabular}{ll}
$\lambda$ & Lambda \\
$\varnothing$ & Female \\
\hdashline & Male
\end{tabular}




\title{
Conceptual Ecological Models to Support Detection of Ecological Change on Alaska National Wildlife Refuges
}

\author{
By Andrea Woodward and Erik A. Beever
}

\section{Abstract}

More than 31 million hectares of land are protected and managed in 16 refuges by the U.S. Fish and Wildlife Service (USFWS) in Alaska. The vastness and isolation of Alaskan refuges give rise to relatively intact and complete ecosystems. The potential for these lands to provide habitat for trust species is likely to be altered, however, due to global climate change, which is having dramatic effects at high latitudes. The ability of USFWS to effectively manage these lands in the future will be enhanced by a regional inventory and monitoring program that integrates and supplements monitoring currently being implemented by individual refuges. Conceptual models inform monitoring programs in a number of ways, including summarizing important ecosystem components and processes as well as facilitating communication, discussion and debate about the nature of the system and important management issues. This process can lead to hypotheses regarding future changes, likely results of alternative management actions, identification of monitoring indicators, and ultimately, interpretation of monitoring results. As a first step towards developing a monitoring program, the 16 refuges in Alaska each created a conceptual model of their refuge and the landscape context. Models include prominent ecosystem components, drivers, and processes by which components are linked or altered. The Alaska refuge system also recognizes that designing and implementing monitoring at regional and ecoregional extents has numerous scientific, fiscal, logistical, and political advantages over monitoring conducted exclusively at refuge-specific scales. Broad-scale monitoring is particularly advantageous for examining phenomena such as climate change because effects are best interpreted at broader spatial extents. To enable an ecoregional perspective, a rationale was developed for deriving ecoregional boundaries for four ecoregions (Polar, Interior Alaska, Bering Coast, and North Pacific Coast) from the Unified Ecoregions of Alaska. Ecoregional models were then developed to illustrate resources and processes that operate at spatial scales larger than individual refuges within each ecoregion. Conceptual models also were developed for adjacent marine areas, designated as the North Pacific, Bering Sea, and Beaufort-Chukchi Sea Marine Ecoregions. Although many more conceptual models will be required to support development of a regional monitoring program, these definitions of ecoregions and associated conceptual models are an important foundation.

\section{Introduction}

More than 31 million hectares of land are protected and managed in 16 refuges by the U.S. Fish and Wildlife Service (USFWS) in Alaska, representing nearly 81 percent of the entire U.S. refuge system; more than 24 percent of this land base is designated Wilderness. The vastness and isolation of Alaskan refuges make them relatively intact and complete ecosystems. The potential for these lands to provide habitat for trust species is likely to be altered, however, due to global climate change, which is having the most dramatic effects at higher latitudes (Intergovernmental Panel on Climate Change, 2007) and at spatial scales larger than individual refuges. The ability of the USFWS to effectively manage these lands in the future will be enhanced by a regional inventory and monitoring program that integrates and supplements monitoring currently being implemented by individual refuges. Furthermore, to promote effective management of the many species and habitats that cross jurisdictional boundaries, inventory and monitoring questions need to be framed at appropriate temporal and spatial scales.

The U.S. Fish and Wildlife Service in Alaska has conducted inventory, monitoring, and research investigations on the national wildlife refuges it manages for decades. Typically, these efforts are conducted independently by individual refuges. Although questions and issues may be similar among refuges, sampling design and field protocols are often developed for each refuge, potentially limiting the ability to share data among refuges and extrapolate results more broadly. Recognizing the need for its monitoring efforts to address questions at broader spatial scales, the National Wildlife Refuge System (NWRS) program in 
Alaska has begun development of an ecoregional monitoring program, including requesting analytical support from the U.S. Geological Survey via the Science Support Partnership program. Specifically, the U.S. Geological Survey (USGS) is supporting USFWS through analysis of past studies, conceptual modeling of ecoregions, and development of an ecoregional monitoring framework primarily to address response of species and ecosystems to climate change. This assistance will support USFWS as they design and implement refuge-specific inventory and monitoring (I\&M) plans and a regional inventory and monitoring program for Alaska refuges. The potential outcomes of this effort are:

1. Identification of refuge-specific gaps in existing inventory and monitoring based on ecoregional modeling and a better understanding of potential climate change effects;

2. Development of a stronger conceptual foundation for selection of monitoring indicators;

3. Development of consistent study designs across similar surveys;

4. Development of an integrated and cohesive approach to address regionally scaled ecological questions; and,

5. Identification of gaps in natural resource monitoring at the landscape scale to ensure that inventory and monitoring efforts by the USFWS refuges complement other agencies' programs.

In this report, we present initial results of the conceptual modeling phase of ecoregional monitoring program development for the Alaska NWRs. In 2008, refuge staff developed conceptual ecological models for each refuge, and these models were presented for further discussion at the Refuge Biologists' Meeting held in October 2008 in Anchorage. Following completion of the refuge models, USGS was asked to develop terrestrial and marine conceptual ecological models at the ecoregional scale. The purpose of these ecoregional models was to provide a framework for ecoregional monitoring by refuges, and potentially their neighbors. Emphasis is on an ecoregional perspective and the effects of climate change. This report presents background on the role of conceptual models in developing monitoring programs. We then discuss the terrestrial and marine ecoregions of Alaska and how the Alaska NWRs are distributed relative to these ecoregions. Next, terrestrial ecoregional models are presented, and refuge-specific models and marine models are presented in the appendixes. We then provide a brief synthesis of the models and an assessment of next steps for ecoregional monitoring program development. The major geographic features of Alaska are presented in figure 1.

\section{Role of Conceptual Ecological Models in Monitoring}

Conceptual ecological models describe relationships among ecosystem components and processes, and reveal the assumptions and perspectives held by those constructing the model. Conceptual models can take many forms, including written descriptions and tables (Noss, 1990), or visual representations such as structural diagrams (box-andarrow; EMAP, 1990), and 3-D illustrations (Thornton and others, 1994). Constructing conceptual models can facilitate communication among a diverse group of people to enable problem solving. For land-management agencies in the process of developing inventory and monitoring programs, the relevant group may include representatives of different biological disciplines, other natural science disciplines, social scientists, and land managers (Heemskerk and others, 2003).

Developing a conceptual model of the ecosystem is a critical first step in monitoring because such models aid in framing the management questions and the indicators most relevant to those questions (Barber, 1994; National Research Council, 1995; Noon and others, 1999; Boutin and others, 2001; Noon, 2003). Conceptual ecological models represent working hypotheses about ecosystem organization, function, and inter-relationships (Huggett, 1993; Manley and others, 2000). By distilling numerous ecosystem components and processes, the models can shed light on how ecological monitoring may be structured at various spatial and temporal scales, and what indicators would be most critical to include. Maddox and others (1999) summarized how conceptual models inform monitoring programs:

1. Models summarize the most important ecosystem descriptors, spatial and temporal scales of major biological processes and current and potential threats to the system.

2. The process of developing models facilitates discussion and debate about the nature of the system and important management issues and questions. These discussions can help managers clarify goals, objectives, indicators, management strategies, and the most important results needed.

3. The process of developing conceptual ecosystem models can help managers determine the most appropriate indicators for monitoring. The model is a statement of important biological and physical processes, and therefore identifies aspects of the ecosystem that, if measured, can provide information about ecosystem status and trends. 


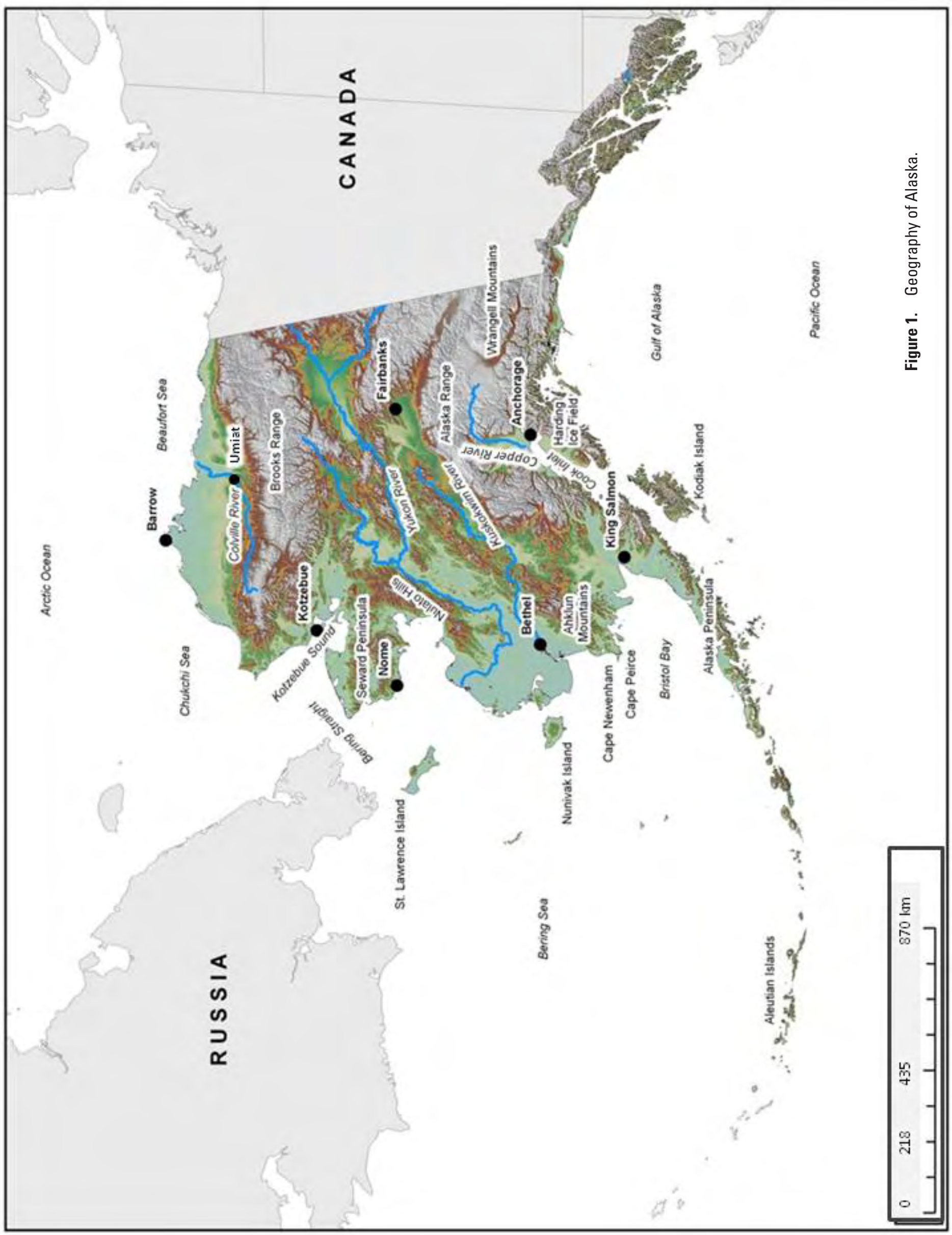


4. Conceptual models can provide a framework for interpretation of monitoring results. Monitoring results should be used to update the ecological model, which is the summary statement of current understanding of the system. Monitoring results may support or conflict with current understanding, thereby contributing to evolution of knowledge and understanding. Models are expected to evolve over time as they are developed, tested, and informed by new data and knowledge.

5. Models offer templates for assessing possible alternative management strategies. Models may be useful for understanding the impacts of various management actions, natural ecological variability, and humaninfluenced change.

Planning for monitoring in the USFWS nationally will likely be guided by the adaptive management process (Melinda Knutson, U.S. Fish and Wildlife Services, oral commun., 2009), which is a particular case of Structured Decision Making (SDM; Williams and others, 2007). The process involves identifying management objectives and potential management actions, then using models representing alternative hypotheses of ecosystem function to predict outcomes of management actions. Monitoring data are used to assess the state of priority resources as well as to weight the models according to outcomes so that future predictions can reflect the results of the most accurate models (Lyons and others, 2008). The goal is to use monitoring to address critical uncertainties and to inform future management decisions by learning from past experience (Nichols and Williams, 2006; Lyons and others, 2008).

In Structured Decision Making, conceptual models together with legal mandates and other management considerations can form the basis for setting 'fundamental' management objectives (e.g., healthy populations of a particular species), that reflect both statutory and ecological importance. Additionally, conceptual models describing ecosystem function can help identify the means by which the fundamental objective will be achieved (e.g., provide habitat for the particular species). Finally, conceptual models can suggest potential management actions, and form the basis of quantitative models that can be used to predict their outcomes. Ecosystem elements described in these models can identify the pool of potential monitoring indicators.

Just as there is no single format for a conceptual model, there is no single model that adequately describes an entire ecosystem or ecoregion because models must balance the ideals of generality and realism. Model generality is needed to characterize broad-scale influences and relationships among resources. In contrast, achieving model realism requires enough detail to identify specific potential expressions of change that could be effective indicators to monitor. Consequently, both integrative general models and moredetailed specific models are needed to represent systems having the spatial scale and ecologic complexity of wildlife refuges, and to support development of a monitoring program. Models with the generality to describe an entire refuge will include few details about individual ecosystem components and will instead provide a broad overview of how those components interact. Achieving model realism necessary for indicator selection can be likened to moving a magnifying glass around individual ecological systems or management issues. With each change in position, some elements are brought into sharp focus, while others are fuzzy. Monitoring programs frequently choose to develop a hierarchy of models at different spatial and temporal scales to deal with the inability of one model to contain all of the important information (MacCluskie and Oakley, 2005; Miller, 2005; Miller and others, 2010).

In this document, we focus on ecoregional and refugescale conceptual models for the 16 national wildlife refuges in Alaska. At the refuge scale, conceptual models illustrate how refuge ecosystems and resources are driven and stressed, particularly by climate change, by presenting in a visual format working hypotheses that explain current linkages between biotic and abiotic components. The purpose is to provide an integrated view of refuge components and processes, which will contribute to determining management objectives that ultimately lead to selection of indicators useful for long-term monitoring. Ecoregional-scale models are used to identify the ecosystem processes and components that link groups of refuges with each other and with units of other agencies, thereby identifying potential areas for collaboration. Potential effects of climate change are described, but not illustrated.

The process of developing the conceptual models presented in this report is only the first step toward developing a monitoring framework. The models themselves will be revised as refuge staff continue to incorporate newly obtained information. Moreover, the ecological perspective presented in these models must ultimately be combined with considerations of legislative and statutory mandates and agency regulations to inform the priorities and design of ecoregional monitoring among Alaska national wildlife refuges, and identify topics for collaboration with other agencies. 


\section{Ecoregional Context of Alaska NWRs}

To meet the USFWS goal of addressing regionally scaled ecological questions and to lay a foundation for potential integration of monitoring among land-management agencies, it is useful to first understand the ecoregional context of the refuges. Ecoregions are areas having similar patterns of mosaics of abiotic and biotic ecosystem components, including both aquatic and terrestrial environments (McMahon and others, 2001; Omernick, 2004). They are delineated primarily to facilitate cross-agency research, assessment, and management of entire ecosystems (Omernik, 2004). However, the challenge of deriving discrete categories from multiple, overlapping gradients of resource distribution means that many delineations are possible depending on which resources are emphasized. Using extant ecoregional terrestrial and marine ecoregional delineations for Alaska, we will present a rationale for an ecoregional classification system appropriate for use by Alaska NWRs to advance further development of their inventory and monitoring program.

\section{Terrestrial Ecoregions of Alaska}

To build an ecoregional classification for the refuges of Alaska, we began with the 32 'unified ecoregions' developed for terrestrial Alaska by Nowacki and others (2002). The classes primarily are defined by climate and topography, and secondarily by vegetation patterns, lithology, and surficial soil deposits (fig. 2; Nowacki and others, 2002). These ecoregions span tens of thousands of square kilometers, and correspond to the Province level of Bailey $(1980,1995)$. The ecoregions describe latitudinal bands and reflect a separation of coastal versus continental climates (fig. 2).

Nowacki and others (2002) classify the 32 unified ecoregions into eight 'Level-1' groups, reflecting gradients in climate (temperature and precipitation), vegetation-related factors (forested to non-forested), and disturbance regime (fig. 3). Each of the Level-1 groups exhibits similar ecological patterns and processes. The Level-1 groups can be further aggregated into three groups representing, at the broadest scale, polar, boreal, and maritime climate-vegetation regimes.

For the purposes of grouping refuge conceptual models, we started with the three broadest scale climate-vegetation regimes of boreal, polar, and maritime. We recognized that refuges occupying coastal areas of western Alaska (i.e., Bering Taiga and Bering Tundra groups) experience different sets of ecosystem dynamics relative to ecosystem composition, structure, and function compared with inland areas. We therefore decided to split the Bering Sea coast from the Polar and Boreal realms of Nowacki and others (2002).

Consequently, the framework we suggest for terrestrial ecoregional models consists of four ecoregions, which we call Polar, Bering Coast, Interior Alaska, and North Pacific Coast (fig. 4).

The organizing framework presented here represents one of numerous options that could be selected to guide conceptual modeling of refuges and adjacent lands. We suggest this framework as the foundation for creating ecoregional conceptual models for several reasons. By using a multidisciplinary approach, this classification system provides context for a diversity of ecosystem components that may be monitored within NWRs and other DOI lands. Pragmatically speaking, the four ecoregions in this framework represent a compromise between using the finest distinctions represented by the 32 unified ecoregions versus using the three most general climate-vegetation classes (ig. 3 ). In the first case, we would minimize the linkages among refuges and other lands; in the second case, we would neglect the important distinction between interior and coastal ecoregions. We also note that these ecoregions are largely defined by latitude and the location of mountain ranges and oceans. Although the growing conditions and biota that occupy these areas may change in the future, we expect there to be some continuity within these ecoregions due to the relatively static features that determine their classification.

There is subjectivity involved in defining ecoregions, and other boundaries may be more appropriate for other purposes or may be adopted for this purpose by others in the future. For example, an alternative system under consideration nationally by USFWS for inventory and monitoring program organization is the system of Landscape Conservation Cooperatives (LCCs; appendix 1). It is likely that the need to further subdivide the four proposed ecoregions will develop as the USFWS begins to engage with other federal agencies regarding monitoring. Specifically, the eastern and western parts of the North Pacific Coast ecoregion may need to be distinguished given the different environments created by the Gulf of Alaska versus the Bering Sea. Additionally,the southern part of the Interior Alaska ecoregion may be subdivided to form a transition zone between the rest of interior Alaska and areas bordering the Gulf of Alaska, as a function of differences in current fire regime and extent of permafrost. 


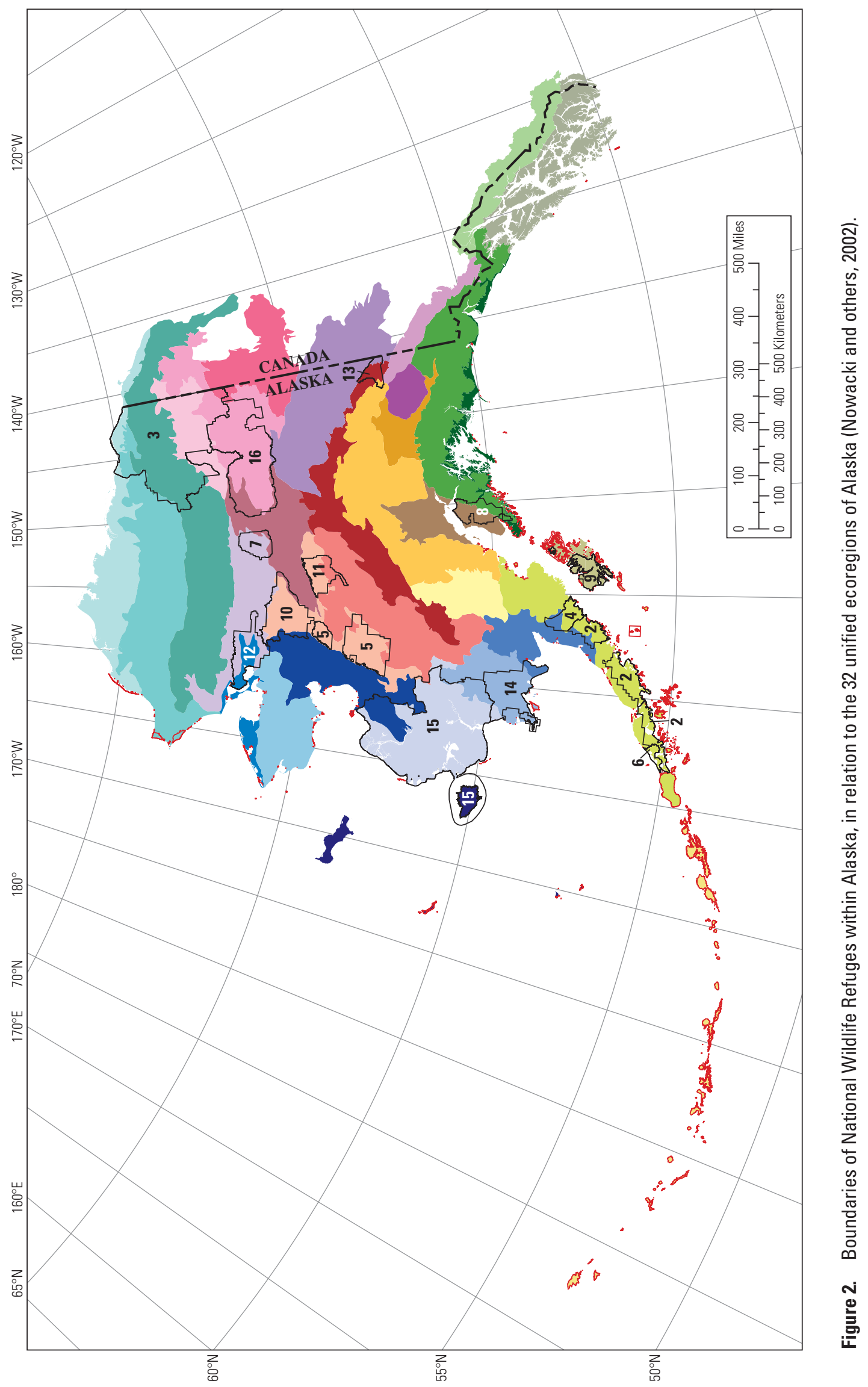




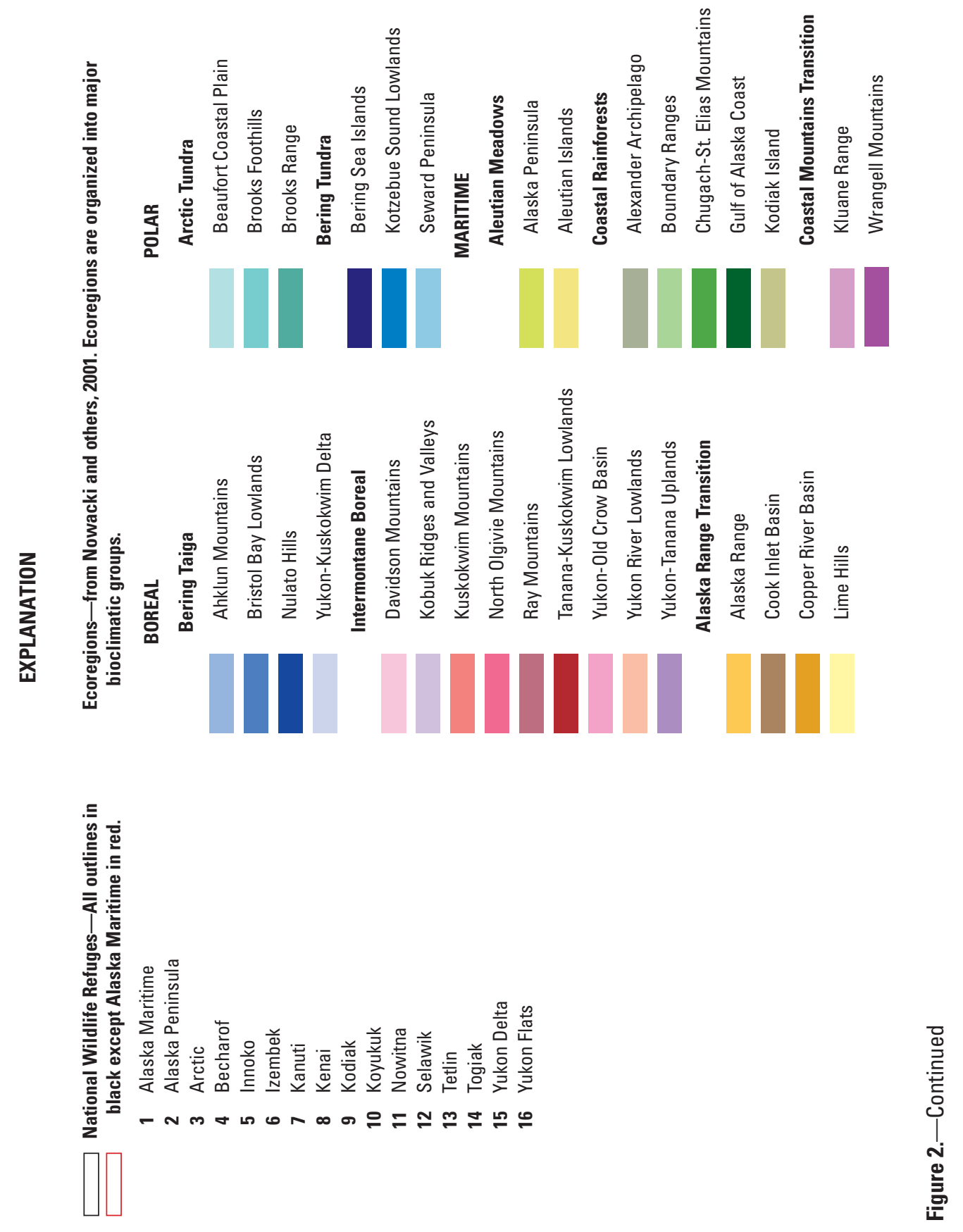




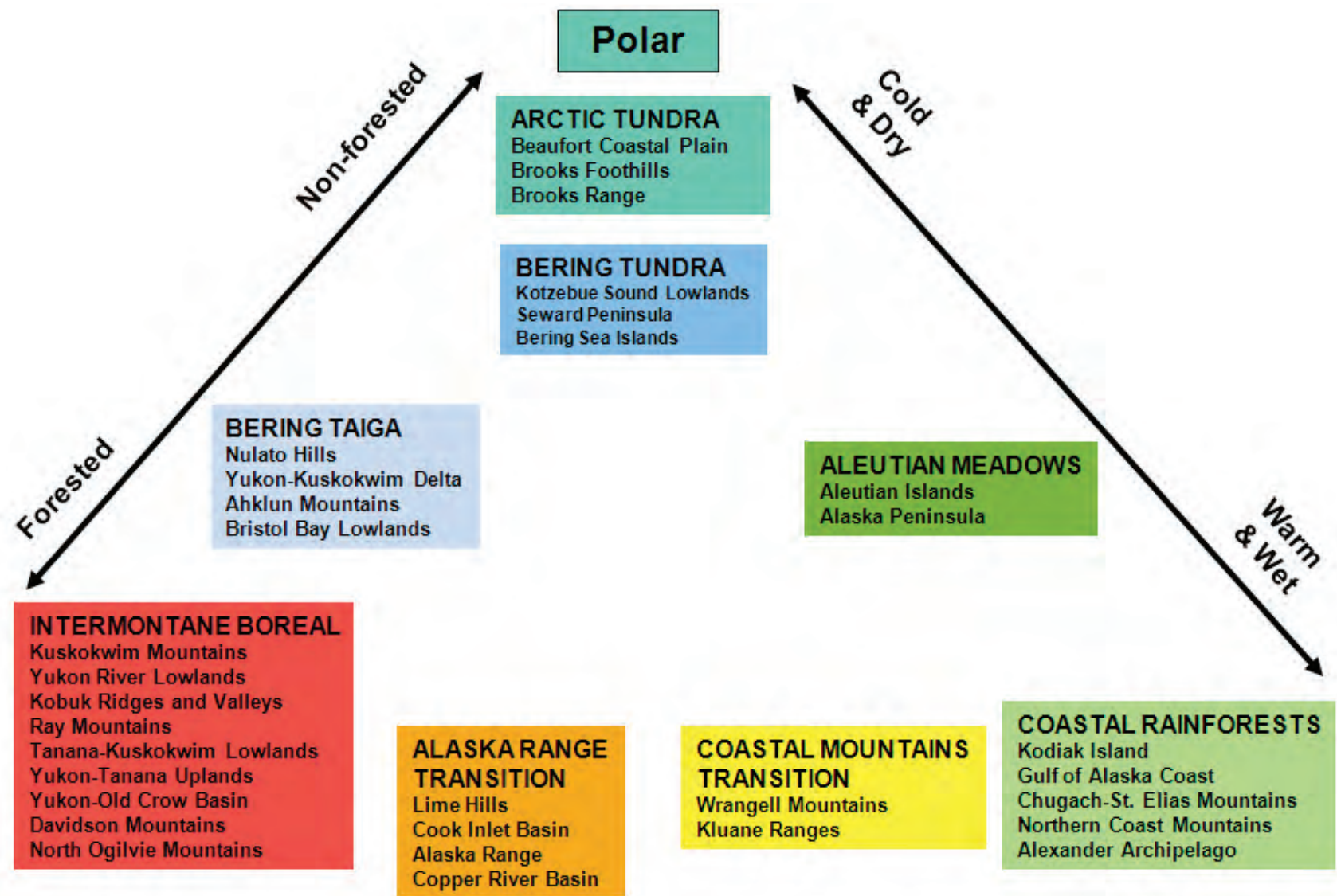

\section{Boreal}

Figure 3. Eight Level-1 groups of the 32 unified ecoregions defined by Nowacki and others (2002).

\section{Distribution of Refuges Among Alaska's Terrestrial Ecoregions}

The majority of refuges within Alaska are within two bands across the state. One extends diagonally from northeast to southwest between the Brooks Range and the Alaska Range; the second extends east to west along the Alaskan and Seward Peninsulas and the Aleutian island chain (fig. 5). In addition, Arctic NWR extends north of the Brooks Range to the arctic coastal plain. Topographically, many refuges were established in part for the conservation of migratory birds, and thus typically exist at lower elevations in Alaska than lands of some other jurisdictions (e.g., the U.S. National Park Service and the U.S. Forest Service; fig. 6).

Refuges include a diversity of ecological components, with each containing an average of 4 of the 32 unified ecoregions (Nowacki and others, 2002). However, individual refuges fall within anywhere from one unified ecoregion (e.g., Izembek and Kodiak NWRs) to 16 unified ecoregions (i.e., Alaska Maritime NWR). Moreover, units of the National Wildlife Refuge system within Alaska collectively intersect 28 (87.5 percent) of the state's 32 unified ecoregions, and contain 


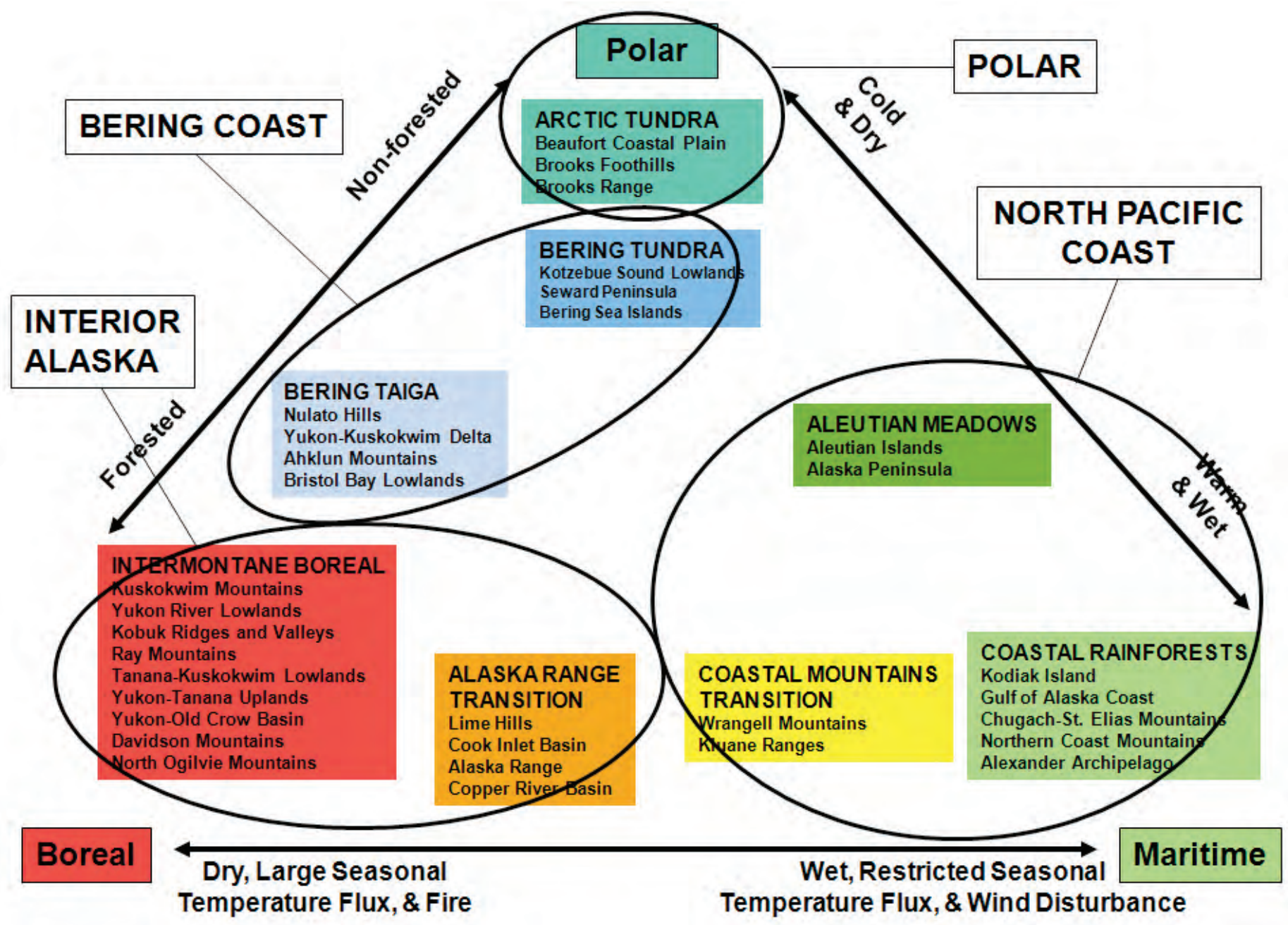

Figure 4. Relationship between the eight Level-1 groups (Nowacki and others, 2001) and the ecoregions used in this report (i.e., Polar, Bering Coast, North Pacific Coast, and Interior Alaska).

lands from all eight Level-1 groups. Among refuge lands, the Intermontane Boreal Level-1 group occupies the greatest area (37.4 percent), followed by Bering Taiga (28.6 percent), and then Arctic Tundra (14.7 percent) and Aleutian Meadows (11.2 percent). As is the case with unified ecoregions, Alaska Maritime again contains the most Level-1 groups (6 of 8).

In terms of the four ecoregions, we propose as an organizing framework (i.e., Polar, Bering Coast, Interior Alaska, and North Pacific Coast; fig. 3 ), 12 refuges have at least 90 percent of their area in one ecoregion (fig. 5, table 1). A notable exception is Alaska Maritime NWR, which spans much of the state's coastline and occurs in all four ecoregions. Four other refuges (Arctic, Selawik, Becharof, and Kenai NWRs) have at least 10 percent of their area in two ecoregions. Of the 16 refuges, 8 predominantly (i.e., $>50$ percent of refuge area) are in the Interior Alaska ecoregion, 5 in the North Pacific Coast ecoregion, 2 in the Bering Coast ecoregion, and 1 in the Polar ecoregion. 


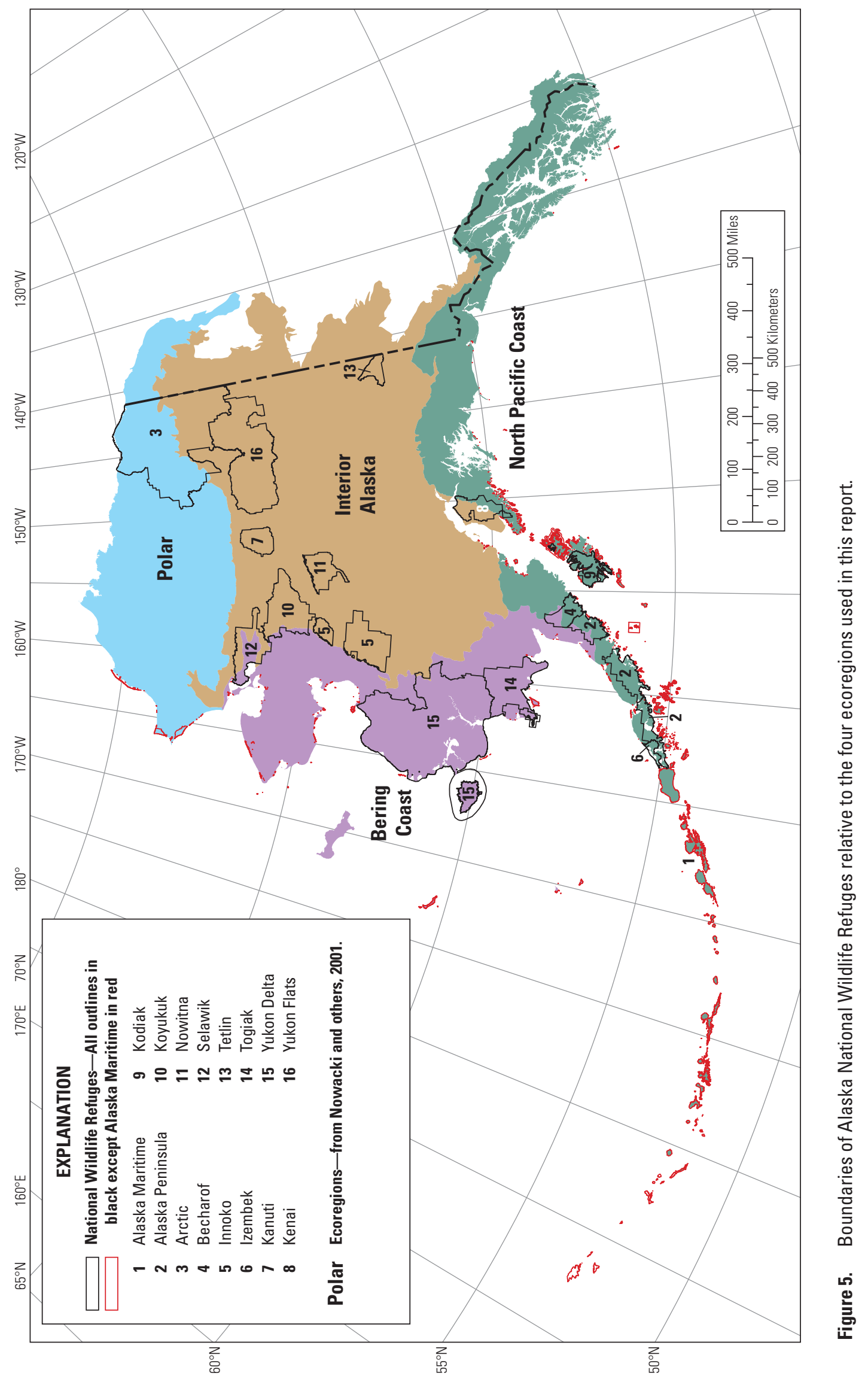




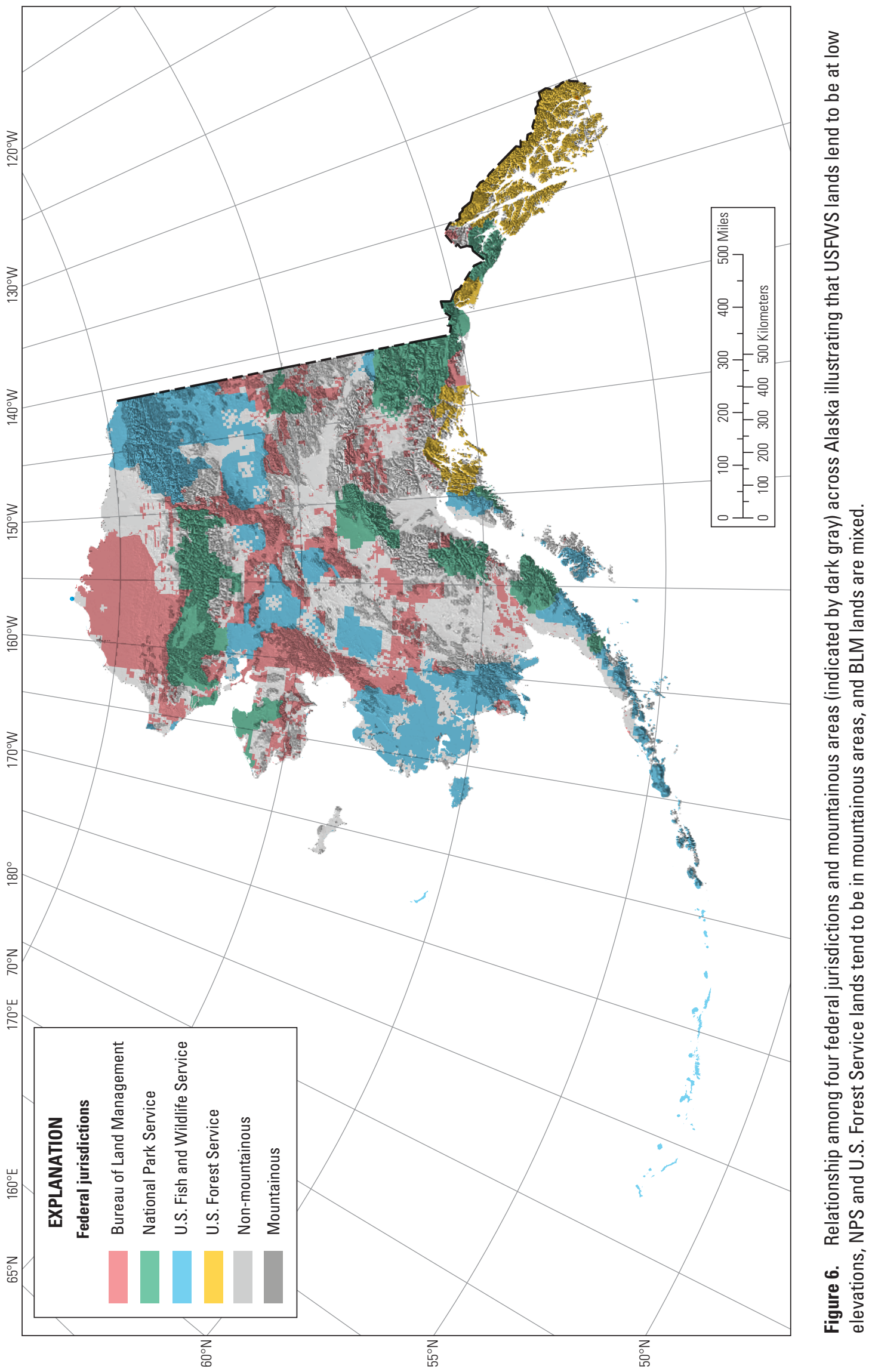


Table 1. Percentages of each Alaska National Wildlife Refuges in Polar, Bering Coast, Interior Alaska, and North Pacific Coast terrestrial ecoregions.

[Locations of refuges are shown in figure 5 . Refuges are listed by percentage of their area occurring in their predominant ecoregion, from highest to lowest percentage in each of the corresponding dominant ecoregions. The refuge-specific models in the appendixes appear in the same order as this list. <, less than; >, greater than]

\begin{tabular}{|c|c|c|c|c|}
\hline \multirow{2}{*}{$\begin{array}{l}\text { National } \\
\text { Wildlife } \\
\text { Refuge }\end{array}$} & \multicolumn{4}{|c|}{ Ecoregion } \\
\hline & Polar & $\begin{array}{c}\text { Bering } \\
\text { Coast }\end{array}$ & $\begin{array}{l}\text { Interior } \\
\text { Alaska }\end{array}$ & $\begin{array}{r}\text { North } \\
\text { Pacific } \\
\text { Coast }\end{array}$ \\
\hline Arctic & 65 & 0 & 35 & 0 \\
\hline Togiak & 0 & 100 & 0 & 0 \\
\hline Yukon Delta & 0 & $>99$ & $<1$ & 0 \\
\hline Kanuti & 0 & 0 & 100 & 0 \\
\hline Nowitna & 0 & 0 & 100 & 0 \\
\hline Yukon Flats & 0 & 0 & 100 & 0 \\
\hline Innoko & 0 & $<1$ & $>99$ & 0 \\
\hline Tetlin & 0 & 0 & $>99$ & $<1$ \\
\hline Koyukuk & 0 & 8 & 92 & 0 \\
\hline Kenai & 0 & 0 & 60 & 40 \\
\hline Selawik & 0 & 46 & 54 & 0 \\
\hline Izembek & 0 & 0 & 0 & 100 \\
\hline Kodiak & 0 & 0 & 0 & 100 \\
\hline Alaska Peninsula & 0 & 6 & 0 & 94 \\
\hline Alaska Maritime & 4 & 3 & 2 & 91 \\
\hline Becharof & 0 & 31 & 0 & 69 \\
\hline
\end{tabular}

\section{Marine Ecoregions of Alaska}

Alaska contains about 53,100 km of coastline, which is more than the total of the entire contiguous U.S. (Shulski and Wendler, 2007). Ten of the 16 NWRs within Alaska, and many lands administered by other Interior agencies, have at least some marine border. Marine-associated factors can influence not only coastal, but also inland, parts of these land units. Such marine factors include the maritime effects on climate (e.g., wind, temperature, precipitation), coastal dynamics (salinity, coastal erosion, shorefast ice), and the exchange of energy, nutrients, water, and pollutants. Jurisdictions of refuges extend varying distances out into marine waters, and many species of high management importance to the USFWS (including anadromous fishes, waterbirds, and marine mammals) spend at least parts of their life cycle in marine waters. Thus, creation of conceptual models for an individual management unit requires consideration not only of the unit's terrestrial context, but also its marine context. This section provides a brief background on the factors used by Piatt and Springer (2007) to delineate marine ecoregions of Alaska (ig. 7).
As with the terrestrial landscape, the heterogeneity in biotic and abiotic factors driving the marine ecosystems surrounding Alaska can be used to classify ecoregions (fig. 7). The boundaries of these marine ecoregions primarily reflect differences in bottom topography and current flow, but also reflect meso-scale patterns in sea-surface temperature, salinity, primary production, and other factors that ultimately lead to concordant geographic distributions of species and communities (Piatt and Springer, 2007). Piatt and Springer (2007; fig. 7) use the term 'ecoregion' to refer to areas distinguished by major physiographic (e.g., slope, shelf, or coastal area) and minor oceanographic variation (following Demarchi, 1996). Within a shelf area, ecoregions might be further subdivided by: (1) currents that dramatically alter production regimes (e.g., the Anadyr Current in the northern Bering Sea; Springer and McRoy, 1993); (2) topographic irregularities that create persistent differences in oceanographic pattern on opposing sides of the feature (e.g., islands such as Kodiak Island); or (3) persistent oceanic fronts associated with 50-m and $100-\mathrm{m}$ isobaths on the Eastern Bering Sea shelf (Coachman, 1986).

The effects of these bathymetric and oceanographic factors on the heterogeneity of ecosystem dynamics are pronounced. Distributions of various marine organisms reflect these physical drivers, and in some cases were used to define placement of ecoregional boundaries (Piatt and Springer, 2007). For example, heterogeneity in bathymetry and oceanography across the continental shelf of the Eastern Bering Sea creates discrete assemblages of plankton, fish, and bird communities within coastal, inner-shelf, outer-shelf, slope, and oceanic domains (e.g., Doyle and others, 2002; Piatt and Springer, 2003). Within open-ocean areas, broad-scale oceanographic processes often structure communities. In the Gulf of Alaska, for example, the Alaska Gyre creates spatial heterogeneity in plankton, fish, bird, and mammal populations (Brodeur and Ware, 1992; Springer and others, 1999). Along continental shelves, currents carrying nutrient-rich waters create a narrow band of habitats possessing high primary productivity and diversity, with some species (e.g., squids, albatross [Phoebastria spp.]) strongly tied to these shelf-edge ecoregions (Sinclair and Stabeno, 2002; Piatt and others, 2006). Finally, spatial heterogeneity in topography and oceanography results in the concordant spatial segregation of certain fish, bird, and mammal populations into three distinct ecoregions along the Aleutian chain (see synthesis by Schumacher and others, 2005). 


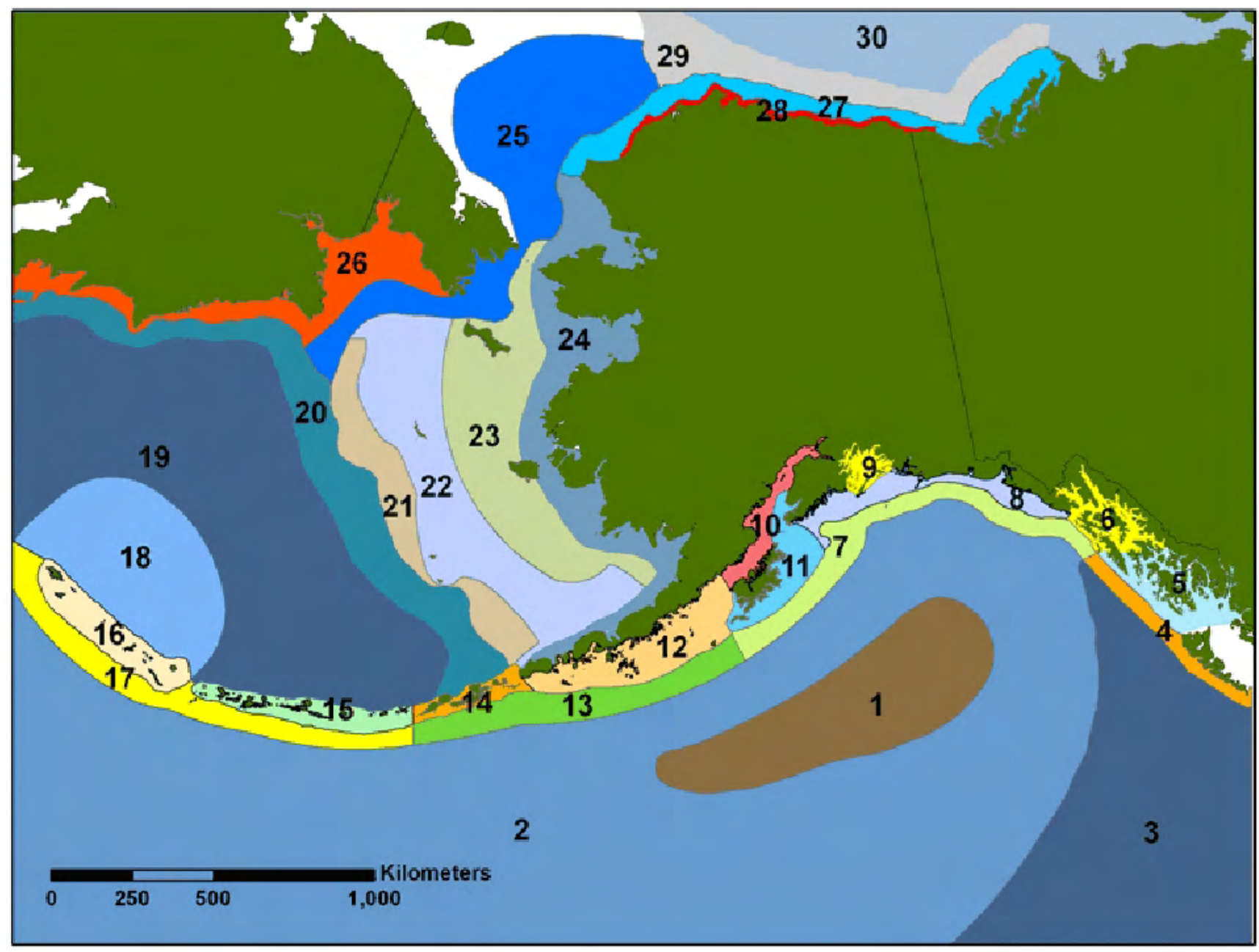

Figure 7. Marine ecoregions of Alaska (Piatt and Springer, 2007). See table 2 for key.

Table 2. Key to the Marine Ecoregions of Alaska.

(Piatt and Springer, 2007).

\begin{tabular}{|r|l||l|l|}
\hline No. & \multicolumn{1}{|c|}{ Ecoregion } & No. & \multicolumn{1}{c|}{ Ecoregion } \\
\hline 1 & Alaska Gyre Center & 16 & Western Aleutians \\
\hline 2 & North Pacific Current - Alaska Stream Loop & 17 & Aleutian Arc - Alaska Stream \\
\hline 3 & Eastern Gulf of Alaska Transitional & 18 & Bering Sea - Bowers Basin \\
\hline 4 & Eastern Gulf of Alaska Slope & 19 & Bering Sea - Aleutian Basin \\
\hline 5 & Prince of Wales Shelf and Inside Waters & 20 & Bering Sea Shelf Edge - Green Belt \\
\hline 6 & Chichagof Shelf and Inside Waters & 21 & Eastern Bering Sea - Outer Domain \\
\hline 7 & Northern Gulf of Alaska Slope & 22 & Eastern Bering Sea - Middle Domain \\
\hline 8 & Northern Gulf of Alaska Shelf & 23 & Eastern Bering Sea - Inner Domain \\
\hline 9 & Prince William Sound Inside Waters & 24 & Eastern Bering Sea - Alaska Coastal \\
\hline 10 & Western Cook Inlet - Shelikof Strait & 25 & Northern Bering - Chukchi Sea - Anadyr Stream \\
\hline 11 & Southeastern Cook Inlet - Kodiak Upwelling & 26 & Western Bering Sea - Shelf \\
\hline 12 & Alaska Peninsula Coastal and Shelf & 27 & Beaufort -Chukchi Coastal - Shelf \\
\hline 13 & Western Gulf of Alaska - Alaska Stream & 28 & Beaufort - Chukchi Sea - Barrier Island-Lagoon System \\
\hline 14 & Eastern Aleutians & 29 & Beaufort - Chukchi Sea - Shelf Edge \\
\hline 15 & Central Aleutians & 30 & Arctic Ocean - Basin \\
\hline
\end{tabular}


As with terrestrial ecoregions, subdividing habitats that vary across numerous continuous axes into discrete categories will always involve subjectivity. The support for the precise location of the boundary between adjacent ecoregions differs among ecoregions. For example, the continental shelf edge relatively consistently defines the shallow and deep edges of the zones that parallel coastlines. That is, the physical and topographic characteristics of shelf-edge, outer, middle, and inner domains constrain these ecoregions to having stable locations (fig. 7). In contrast, temporal variability in the location of weather, currents, and areas of highest productivity can make boundaries more dynamic in the open ocean.

The analyses used to delineate these ecoregions considered only features present during the summer months (Piatt and Springer, 2007). Although mesoscale features evident in the winter undoubtedly affect dynamics of resident and migratory species, the scarcity of data on habitat characteristics from winter prevent detailed description of such classifications.

In spite of uncertainty in some boundaries, several conclusions emerge from these classifications (Piatt and Springer, 2007). First, greater heterogeneity exists at finer spatial scales in coastal-shelf environments, relative to resolution of heterogeneity within the open ocean. Second, heterogeneity perpendicular to the coastline is pronounced and produces conspicuous boundaries defined by topographic gradients or persistent fronts. Third, boundaries along the shelf are less conspicuous, and more typically reflect patterns of animal distribution than physical determinants. Finally, although bottom topography and current flow strongly shape ecoregions, further analyses of physical and biological data would provide greater clarification of ecosystem dynamics and boundaries.

These mesoscale ecoregions (fig. 7) provide one framework that may be useful to scientists and managers for predicting and interpreting the status and trend of biological resources across various spatial scales (e.g., Dragoo and others, 2003). Analogous to the terrestrial unified ecoregions, they can be grouped into coarser categories reflecting broad climatic and oceanographic processes. Examples of higher level classification systems include the Large Marine Ecosystems of Sherman and others (1990) and the Pelagic Bird Conservation Regions (PBCRs) of Kushlan and others (2002) (fig. 8) derived from the Large Marine Ecosystems. We present marine ecoregional models to describe the northern, western, and southern coasts of Alaska (i.e., Polar, East Bering Sea, and North Pacific Marine Ecoregions), which largely correspond to both of these classifications.

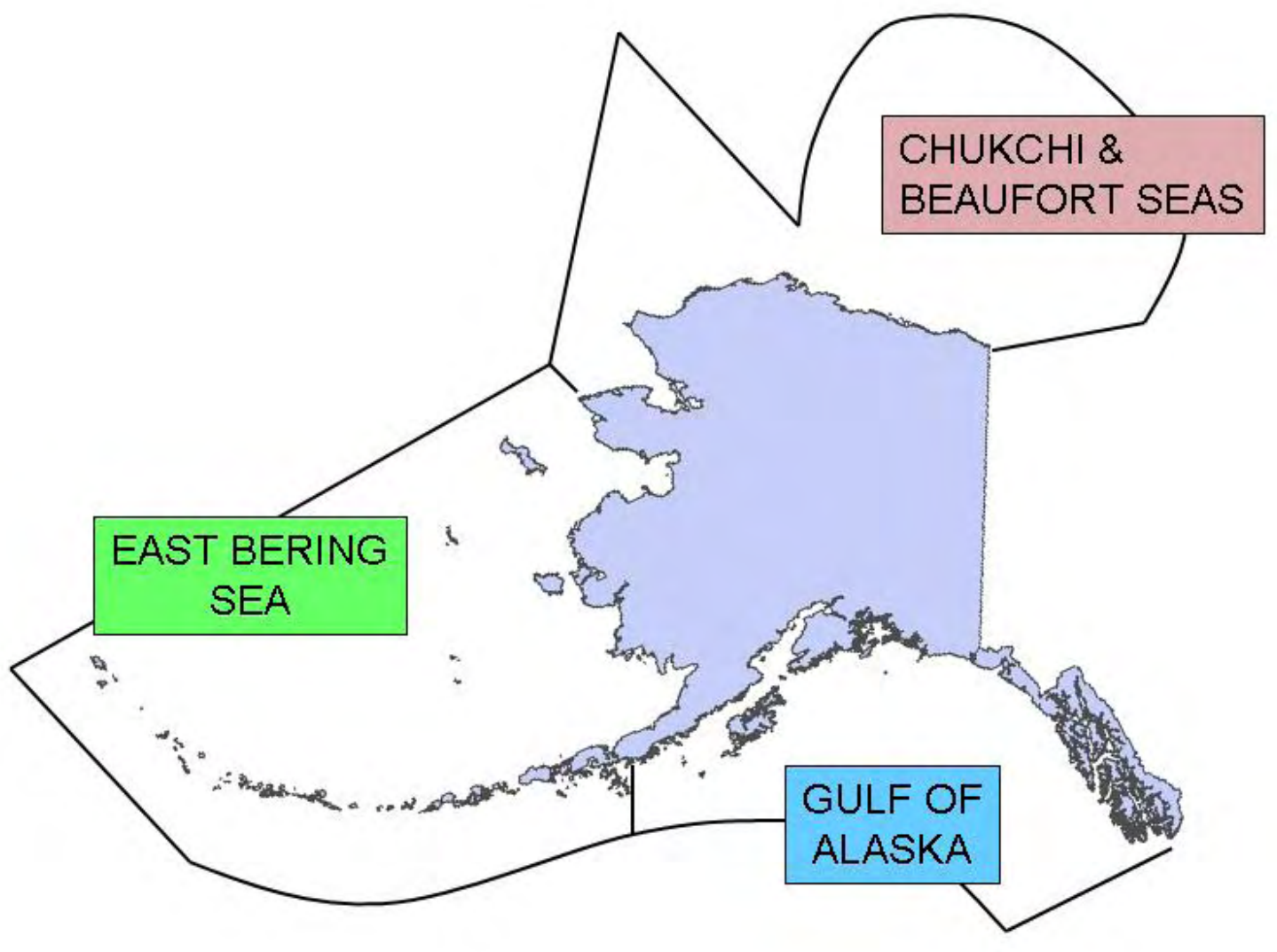

Figure 8. Pelagic Bird Conservation Regions surrounding Alaska (Kushlan and others, 2002). 
The marine ecoregions of Piatt and Springer (2007) nest fairly simply into PBCRs. The Gulf of Alaska PBCR is composed of the first 14 ecoregions of Piatt and Springer (2007), which they use to describe the eastern to western Gulf of Alaska and the enclosed waters of southeastern Alaska and Cook Inlet. The East Bering Sea PBCR includes the ecoregions that Piatt and Springer (2007) generally associate with the Aleutian Islands and the eastern Bering Sea; the Chukchi and Beaufort Seas PBCR generally matches ecoregions on the north coast of Alaska. Ecoregions that do not nest perfectly are the Eastern Bering Sea-Alaska Coastal, which includes both Bristol Bay and Kotzebue Sound, and Northern Bering-Chukchi Sea-Anadyr Stream, which also crosses the Bering Strait. The Western Bering Sea-Shelf ecoregion is not included in the PBCRs.

\section{Distribution of Refuges among Alaska's Marine Ecoregions}

Nine of the 16 NWRs in Alaska have some coastal boundary. Alaska Maritime NWR has units in all three PBCRs, but most of the land base is in the Aleutian Islands Unit, which falls in the East Bering Sea PBCR. The Chukchi and Beaufort Seas PBCR is bordered by Arctic NWR in the western part and Selawik NWR in the eastern part. The East Bering Sea PBCR is bordered by Yukon Delta and Togiak NWRs in the East Bering Sea and Izembek NWR on the south edge of the Alaska Peninsula. Alaska Peninsula, Becharof, Kenai and Kodiak NWRs border the western part of the Gulf of Alaska PBCR.

\section{Ecoregional Models}

In this section, we present preliminary models for the four ecoregions we propose as a framework for further development of an inventory and monitoring program for the Alaska NWRs. These four ecoregions-Polar, Interior Alaska, Bering Coast, and North Pacific Coast-are named following the terrestrial ecoregional schema, but include marine considerations as well. As described previously, the four terrestrial ecoregional groups are based on the highestlevel divisions of Nowacki and others (2001), except that the Bering Tundra and Bering Taiga Level-1 groups of Nowacki and others (2001) are classified here as Bering Coast.

The ecoregional models presented below combine elements from refuge-specific conceptual models for refuges within each of the four terrestrial ecoregions and were supplemented with marine models, and a synthesis of information from the peer-reviewed literature and other sources. The objectives of each ecoregional model are:
- To characterize the ecoregional environmental context by depicting spatial patterns of landcover and permafrost distribution as well as temporal patterns of phenology, and

- To integrate the refuge-specific models within ecoregions by portraying the abiotic and biotic components and processes that operate at largerthan-refuge scales in the ecoregional environmental context.

The ecoregional models highlight ecological processes and components that operate over large spatial scales rather than those that are common but operate at smaller scales. For example, we include sea ice because it experiences regional patterns of movement due to wind and currents, but not coastal erosion because events at one site do not affect events at another site, although the individual events may accumulate over a large area. Likewise, we include caribou (Rangifer tarandus) because individuals migrate hundreds of kilometers, but not wolves (Canis lupus) or moose (Alces alces) whose home ranges are usually smaller than refuges, although these species are both widespread. Moreover, by using a model format that emphasizes spatial pattern (that is, land-cover maps), we limit our ability to depict processes and interactions among ecosystem components and anything occurring below the surface. By limiting our scope in this way, we do not suggest that other aspects of ecoregional dynamics are not worthwhile to contemplate. For example, monitoring objectives may call for consideration of components that are common to all refuges in an ecoregion, or species that are most likely to experience range changes due to climate change. Models could be built to reflect these objectives. Our purpose is not to pre-empt determination of monitoring objectives for the refuges. Rather, we aim to provide one illustration of a tool for considering the ecology of individual refuges in a larger context as a means to develop efficient and effective monitoring indicators once monitoring objectives have been determined.

\section{Polar Ecoregional Model}

\section{Geographic Context}

The Polar Ecoregion occupies the north coast of Alaska, adjacent to the Arctic Ocean, and is entirely north of the Arctic Circle (fig. 9). It consists of three primary landforms: the Brooks Range, foothills, and coastal plain. The coastal plain (blue and beige area at northern edge of Alaska, fig. 9) is broadest across the central north slope of the Brooks Range, where the plain is characterized by a high density of shallow lakes, and is narrower at the western and eastern edges of the ecoregion. 


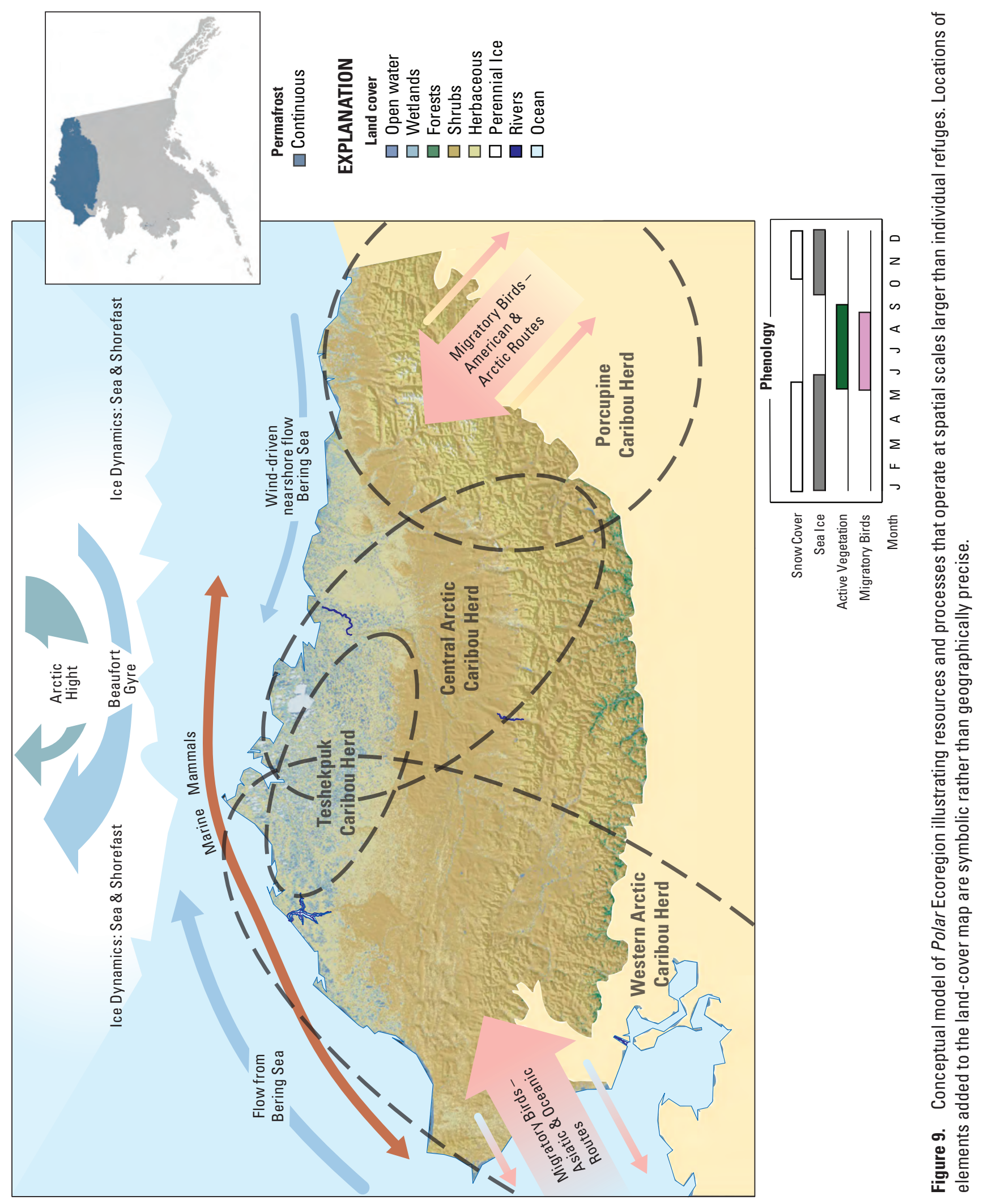


Marine areas bordering the Polar Ecoregion include the Chukchi and Beaufort Seas of the Arctic Ocean. This area corresponds with the Chukchi and Beaufort Seas PBCR (fig. 8) and marine ecoregions 24 through 30 of Piatt and Springer (2007; table 2). Multiple rivers feed these seas, notably the MacKenzie River in Canada and the Colville and Kobuk Rivers in Alaska. The corresponding marine ecosystem is described in appendix 15.

Land management units in the Polar Ecoregion are shown in table 3 . A summary of the components and processes identified in relevant refuge-specific conceptual models and the ecoregional dimension for each of those that operate at the ecoregional scale are listed in table 4.

\section{Ecoregional Abiotic Processes and Components}

The extremely high latitude of the ecoregion dictates a tremendous within-year range in day-length, which has profound effects on climate. Based on available climate data, the Polar Ecoregion can generally be characterized as a polar desert (Shulski and Wendler, 2007) because it experiences a mean air temperature less than $10^{\circ} \mathrm{C}$ during the warmest month and mean annual precipitation less than $250 \mathrm{~mm}$ (table 5). Winters in the ecoregion are long and cold, and are dominated by high

Table 3. Wildlife refuges, land-management units of other agencies, and marine region included in the Polar Ecoregion.

[ $L$ and/marine unit: NWR, National Wildlife Refuge; NM, National Monument; NP, National Park. A gency: BIA, Bureau of Indian Affairs; BLM, U.S. Bureau of Land Management; NPS, U.S. National Park Service; USFWS, U.S. Fish and Wildlife Service.Fine-scale conceptual model: Only models included in this document are listed. See http://science.nature.nps.gov/im/monitor for conceptual models of National Park Service (NPS) units. $\mathrm{km}^{2}$, square kilometer; >, greater than; , approximately]

\begin{tabular}{|l|l|l|}
\hline \multicolumn{1}{|c|}{ Land/marine unit } & \multicolumn{1}{|c|}{ Agency } & $\begin{array}{c}\text { Fine-scale } \\
\text { conceptual } \\
\text { model }\end{array}$ \\
\hline Alaska Maritime NWR & USFWS & Appendix 11 \\
\hline Arctic NWR & USFWS & Appendix 2 \\
\hline National Petroleum Reserve Alaska & BLM & \\
\hline Bering Land Bridge NM & NPS & \\
\hline Cape Krusenstern NM & NPS & \\
\hline Gates of the Arctic NP & NPS & \\
\hline Kobuk Valley NP & NPS & \\
\hline Noatak NP & NPS & \\
\hline$>41,000 \mathrm{~km}^{2}$ & State of Alaska & \\
\hline$\sim 26,000 \mathrm{~km}^{2}$ & BIA & \\
\hline Beaufort-Chukchi Sea & & Appendix 15 \\
\hline
\end{tabular}

winds and blowing snow. Summers are typically cool and cloudy, although temperatures are slightly warmer inland. Precipitation is scant, and falls primarily during summer, although high winds reduce efficiency of detecting precipitation (thus causing ‘undercatch'; Black, 1954). Winds in the region are strongest along the coast and typically come from the east; wind-free conditions occur only 1 percent of the time (Shulski and Wendler, 2007). Understanding of the ecoregion's climate is biased by the fact that most climate-observing stations in the region occur on the coast; Umiat on the Colville River is the only inland site with a long-term climate record (Shulski and Wendler, 2007).

The physical template upon which biological processes operate in the Polar Ecoregion reflects the cold climate and consequent continuous distribution of permafrost (Shur and Jorgenson, 2007; Jorgenson and others, 2008) that may reach $650 \mathrm{~m}$ in depth (Gold and Lachenbruch, 1973). Although permafrost properties (e.g., ice distribution, active layer depth, thermal regime) vary dependent on local features (i.e., topography, soils, surface and ground water, soil moisture, snow, and vegetation) (Péwé, 1975; Lachenbruch and others, 1987; Jorgenson and others, 2008), the pervasive effects of permafrost are to impede water flow and to settle upon thawing (Yoshikawa and Hinzman, 2003), thereby affecting the flow and impoundment of water. Consequences for the Polar Ecoregion include a high run-off ratio for meltwater and precipitation in the mountains and foothills; thawlakes (up to 50 percent of coastal plain), braided rivers and streams, and extensive wetlands in the lowlands (Nowacki and others, 2001); and characteristic geomorphic features such as ice wedge polygons (Jorgenson and others, 2008). Rivers in the eastern part of the region are fed by a handful of alpine glaciers (Hock and others, 2005) and tend to build deltas. In general, rivers and lakes have low average temperatures, short open-water periods, and because many freeze to the bottom, there are few over-wintering areas for fish (Craig, 1989).

The hydrologic cycle in the Polar Ecoregion reflects that approximately 40 percent of annual precipitation falls as snow (Shulski and Wendler, 2007). Snow melt occurs during a brief period in spring, followed by summer rains, which tend to fall later in the season. Stream hydrographs show a peak due to snowmelt in coastal plain watersheds and rainfall-driven flow in foothill and mountain streams. Glaciers and widely distributed springs maintain a moreeven annual flow regime in eastern rivers (Ford and Bedford, 1987; Yoshikawa and others, 2007). 
Table 4. Summary of elements included in refuge-specific terrestrial models from the Polar Ecoregion and Beaufort-Chukchi Seas marine model, and description of representation of elements in the ecoregional model.

[See table 3 for locations of fine-scale models; see figure 9 for elements in the ecoregional model]

\begin{tabular}{|c|c|c|}
\hline & Component or process from fine-scale models & Representation in ecoregional model \\
\hline \multirow{7}{*}{ 吕 } & Climate & Arctic high pressure system \\
\hline & Permafrost & Spatial pattern of permafrost classes \\
\hline & Glaciers & Landcover class_-snow and ice \\
\hline & Rivers & Landcover class - rivers \\
\hline & Sea ice & Location of sea ice \\
\hline & Marine currents —Coastal, Anadyr, Beaufort Gyre & Path of currents \\
\hline & Marine stratification and chemistry & \\
\hline \multirow{6}{*}{.$\stackrel{0}{\frac{0}{0}}$} & Migratory and resident birds & $\begin{array}{l}\text { Flyways for migratory species: shorebirds, waterfowl, raptors, } \\
\text { songbirds, seabirds }\end{array}$ \\
\hline & Terrestrial vegetation & Landcover classes - forests, shrubs, herbaceous \\
\hline & Terrestrial mammals & Annual extent of long-distance migrants: caribou \\
\hline & Marine mammals & $\begin{array}{l}\text { Migration route of long-distance migrants: bearded seals; } \\
\text { beluga, bowhead, gray, and orca whales; polar }\end{array}$ \\
\hline & Fish & \\
\hline & Marine algae, phytoplankton, benthos & \\
\hline
\end{tabular}

Table 5. Summary of weather statistics for the Polar Ecoregion.

[From Shulski and Wendler (2007). Records are based on five land-based stations (mostly near the coast) for 1971-2000. \%, percent; ${ }^{\circ} \mathrm{C}$, degrees Celsius; mm, millimeter; cm, centimeter]

\begin{tabular}{|l|c|}
\hline \multicolumn{1}{|c|}{ Weather variable } & Range across stations \\
\hline Mean annual temperature & $-12^{\circ} \mathrm{C}$ \\
\hline Mean July high temperature & 8 to $19^{\circ} \mathrm{C}$ \\
\hline Mean February low temperature & -30 to $-35^{\circ} \mathrm{C}$ \\
\hline Period below freezing & 283 to 325 days \\
\hline Mean annual precipitation & 102 to $127 \mathrm{~mm}$ \\
\hline Mean annual snowfall & 74 to $85 \mathrm{~cm}$ \\
\hline Median snow period - Barrow & August 26 to June 19 \\
\hline Mean clear days (0-30\% cloud cover) - Barrow & 66 \\
\hline
\end{tabular}


In the marine realm, the Beaufort Sea has a relatively narrow shelf $(<85 \mathrm{mi})$, especially north of Alaska, while the Chukchi Sea is uniformly shallow, with the majority being less than $50 \mathrm{~m}$ deep. Ocean conditions, including circulation and sea ice distribution, influence both the marine and terrestrial environments. Ocean circulation includes currents flowing from the Pacific through the Bering Strait, which either continue north or curve to the east along the Alaska Coast. Further north in the Arctic Ocean, the Beaufort Gyre circulates in a clockwise direction. Outflow of the Arctic Ocean is to the Atlantic Ocean by passing around Greenland or through the Canadian islands. The condition of sea ice reflects climate and also has pervasive effects on climate for many kilometers inland (Shulski and Wendler, 2007), as well as a host of effects on nearshore and offshore marine conditions and components (see appendix 15).

\section{Ecoregional Biotic Processes and Components}

Vegetation in the coastal plain and foothills reflects the saturated soils caused by permafrost and consists largely of wetland communities (MacCarthy, 1952; Lachenbruch and others, 1987; Nowacki and others, 2001; Frey and McClelland, 2009). Sedge and tussock tundra predominate, whereas willow thickets occupy river banks. Vegetation near the crest of the Brooks Ranges is typically alpine tundra and barrens. Arctic treeline crosses the southern part of the ecoregion, as evidenced by sparse conifer-birch forests and tall shrublands on the southern slope of the Brooks Range (fig. 9). These communities show rapid changes in primary production at 'green-up' and 'ice-out' of water bodies, and are used by irruptive insects and migratory animals, which access the area during the short growing season.

Long-distance terrestrial migrants include caribou, specifically the Western Arctic, Central Arctic, Porcupine, and Teshekpuk herds. Caribou are dependent on high-quality forage for reproductive success (Cameron and others, 2000, 2002). Avian migrants, primarily waterfowl and shorebirds, use the area for nesting, brood rearing, and autumn staging (Johnson and Herter, 1989). Different strategies for using polar resources are exemplified by tundra swans (Cygnus columbianus), which take advantage of high quality food resources to nest and raise young; and snow geese (Chen caerulescens), which winter in California and Mexico, nest in Canada and fatten on cotton grass (Eriophorum vaginatum) in late August and September before returning south.

Marine migrants include several whale species (beluga [Delphinapterus leucas], bowhead [Balaena mysticetus], gray [Eschrichtius robustus], orca [Orcinus orca]) and seals (spotted [Phoca largha], some bearded [Erignathus barbatus]) (Davis and Thomson, 1984). Of these species, only bowhead and beluga whales are numerous in the Beaufort
Sea (Carmack and MacDonald, 2002). The timing and spatial pattern of marine migrations depend on the distribution of sea ice (Carmack and MacDonald, 2002; Bradstreet, 1982; Davis and Thomson, 1984; Tynan and DeMaster, 1997). In addition, the location of pack ice determines the distribution of walruses (Odobenus marus divergens) and bearded seals. These species are benthic feeders with depth ranges of less than $100 \mathrm{~m}$ and they haul out, often on large aggregations, on ice edges. Consequently, they thrive when the edge of the pack ice is over the shallow shelf of the Chukchi Sea (Davis and Thompson, 1984; Tynan and DeMaster, 1997).

Several species of anadromous fish inhabit the Polar Ecoregion (National Research Council, 2003). Of these, arctic cisco (Coregonus autumnalis) and broad whitefish (Coregonus nasus) are important subsistence-use species. In contrast to anadromous fisheries elsewhere, none of the currently present anadromous species necessarily die where they spawn, therefore transfer of marine-derived nutrients to terrestrial and freshwater environments is negligible.

A large part of the production in the Chukchi Sea is transported there through the Bering Strait from the Bering Shelf Edge. This massive infusion of nutrients and zooplankton carried by the Anadyr current creates some of the highest marine productivity in the world (Piatt and Springer, 2003).

\section{Potential Effects of Global Change}

The potential effects of climate change on the polar environment have been detailed by Martin and others (2009) in the summary of a workshop to address concerns about the future of wildlife populations. Changes to the abiotic environment include altered hydrology due to changes in the timing, amount, and state (snow versus rain) of precipitation, in addition to the direct effects of higher air temperature on plants, animals, soils and water. Hydrologic changes along with thawing of permafrost and sea level rise are predicted to alter geomorphic processes (Lachenbruch and others, 1987). Altered processes may include coastal erosion, erosion of barrier islands, saltwater inundation (Flint and others, 2008; Jones and others, 2009), the distribution and abundance of thaw lakes and wetlands, lake connectivity and erosion/ sedimentation dynamics (Gooseff and others, 2009). Finally, rising temperatures and greater summer aridity are already causing wildfire to be an increasingly important driver (Jones and others, 2009). By-products of fire include the softening of surface-soil horizons and consequent soil failures (e.g., thaw slumps, thermokarsts); release of carbon and methane into the atmosphere and nearby lakes via combustion and accelerated thawing of permafrost; and higher rates of decomposition (Kling and others, 1991). 
Several plant communities in the ecoregion may shift their distributions in response to climate change. First, increased temperatures may push treeline higher on the south slope of the Brooks Range (Elsner and Jorgenson, 2009), although the evidence is equivocal (Chapin and Starfield, 1997; Rupp and others, 2001). Second, peat-forming bogs of Sphagnum moss may form in drained lakes or thermokarst pits (Gajewski and others, 2001), creating poor habitat for herbivores due to the unpalatability of vegetation. Finally, shrubs have been expanding into areas previously dominated by sedge (Carex spp.; Sturm and others, 2001; Tape and others, 2006). Consequences may again include poorer quality forage for most large herbivores, as well as the possibility of a positive feedback to global warming (Sturm and others, 2001), and potentially increased frequency of tundra fires (Higuera and others, 2008). Overall, biomass of vegetative cover has been increasing in this ecoregion (Verbyla, 2008), possibly due to a longer growing season (Riordan and others, 2006).

Potential impacts of climate change on wildlife vary by taxonomic group (see Martin and others, 2009). Birds may show greater reproductive success with longer growing seasons, however the potential drying of wetlands and loss of coastal lagoons, as well as a trophic mismatch with insect emergence, could be detrimental. Fish populations may have a harder time accessing overwintering habitat due to loss of hydrologic connectivity resulting from drying conditions, and increasing water temperatures may limit the availability of habitat within the thermal range of some species. Terrestrial mammals may benefit from longer growing seasons and greater access to forage and prey; however, forage may be of lower quality and competition with immigrating predators may increase (e.g., red foxes [Vulpes vulpes] expanding their distribution from the south may out-compete arctic foxes [Alopex lagopus]). Longer growing seasons also may result in greater abundance and expanded distribution of insects, pests, parasites, and disease-causing organisms. Potentially deeper snow packs and more-frequent freeze-thaw cycles may also impede the feeding and movement of mammals in winter.

In the marine realm, climate change is affecting the amount and timing of inputs of freshwater, and terrestrial sediments and nutrients; and the timing of ice formation and melt. Among these changes, the most obvious result is that sea ice is declining (Intergovernmental Panel on Climate Change, 2007; Stroeve and others, 2007). Reduction in ice cover enhances heat transfer from the water to the atmosphere (Meehl and Washington, 1990), creating a positive feedback to global warming. Reductions may also change the trophic structure of the ecoregion by affecting mixing, light levels and turbidity (Jones and others, 2009). Changes in salinity could affect global thermohaline circulation (Intergovernmental Panel on Climate Change, 2007), which could have sudden and dramatic consequences for the global climate regime. Changes in the timing and location of resource availability relative to migrations of both marine mammals and anadromous fish (Carmack and MacDonald, 2002) are of concern. The fact that sea ice is becoming increasingly distant from shore is already affecting marine wildlife and seabirds, as well as the humans that depend on access to the rich fauna associated with the ice edge (Gearhead and others, 2006; Laidler and others, 2009). Degrading sea ice also may increase the human access and may lead to greater resource extraction and human infrastructure (Richardson, 1995; Tynan and DeMaster, 1997).

\section{Bering Coast Ecoregional Model}

\section{Geographic Context}

The Bering Coast Ecoregion includes western Alaska (fig. 10), which borders the eastern Bering and southern Chukchi Seas from Bristol Bay to Kotzebue Sound. It includes the Ahklun Mountains, the Yukon-Kuskokwim coastal plain, the Nulato Hills, the Seward Peninsula, and St. Lawrence and Nunivak Islands, and marine ecoregions 21 through 24 of Piatt and Springer (2007; table 2). This ecoregion is characterized by a maritime-influenced climate and is demarcated from the Interior Alaska Ecoregion roughly by the boundary between shrub/tundra and spruce-forest (Nowacki and others, 2001).

Both Yukon Delta and Togiak NWRs include coastal, intertidal, and off-shore marine areas within their boundaries. Specifically, Yukon Delta includes an approximately $25-\mathrm{km}$ ring around Nunivak Island and Togiak includes up to $8 \mathrm{~km}$ of marine habitat off Capes Newnham and Peirce. A conceptual model of the eastern Bering Sea appears in appendix 16.

Land management units in the Bering Coast Ecoregion are shown in table 6. A summary of components and processes identified in relevant refuge-specific conceptual models and the ecoregional dimension for those that operate at the ecoregional scale are shown in table 7.

\section{Ecoregional Abiotic Processes and Components}

Based on 11 weather stations located from Kotzebue to King Salmon, Shulski and Wendler (2007) describe the mean annual temperature in this ecoregion as near to or below freezing (table 8) and becoming colder with increasing latitude. Although mean annual temperature is similar to corresponding areas at the same latitude in the Interior Alaska Ecoregion, the range of extremes is moderated by the region's proximity to the Bering Sea. However, the presence of sea ice from late autumn until late spring diminishes the marine influence on terrestrial climate of the Bering Coast during this period. Precipitation is highest in July and August, when summer storms can accumulate moisture as they pass over the open water of the Bering Sea. The snow season is slightly longer than for Interior Alaska, but maximum snow depth is somewhat lower. Other notable weather features include high winds, which are common throughout the year but are especially strong in autumn and winter; and frequently cloudy skies. 

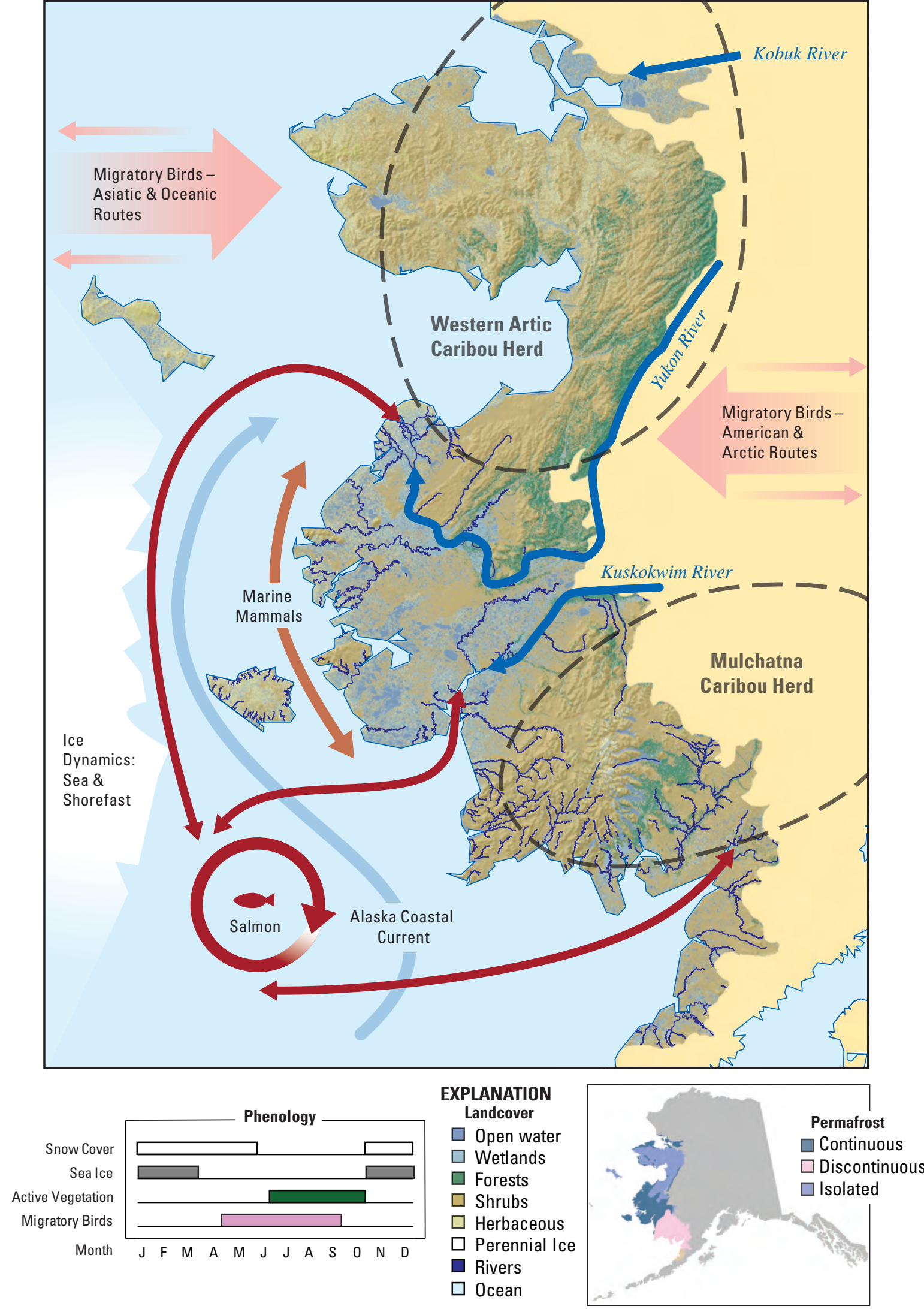

Figure 10. Conceptual model of the Bering Coast Ecoregion, illustrating resources and processes that operate at spatial scales larger than individual refuges. [Locations of elements added to the landcover map are symbolic rather than geographically precise.] 
Table 6. Wildlife refuges, land-management units of other agencies, and marine region in the Bering CoastEcoregion.

[L and/marine unit: NWR, National Wildlife Refuge; NP, National Park. A gency: BLM, U.S. Bureau of Land Management; NPS, U.S. National Park Service; USFWS, U.S. Fish and Wildlife Service. Fine-scale conceptual model: Only models included in this document are listed. See http://science. nature.nps.gov/im/monitor for conceptual models of National Park Service (NPS) units. km², kilometers; >, greater than]

\begin{tabular}{|l|l|l|}
\hline \multicolumn{1}{|c|}{ Land/marine unit } & \multicolumn{1}{|c|}{ Agency } & \multicolumn{1}{c|}{$\begin{array}{c}\text { Fine-scale } \\
\text { conceptual model }\end{array}$} \\
\hline Alaska Maritime NWR & USFWS & Appendix 11 \\
\hline Selawik NWR & USFWS & Appendix 8 \\
\hline Togiak NWR & USFWS & Appendix 8 \\
\hline Yukon Delta NWR & USFWS & Appendix 8 \\
\hline Bering Land Bridge NP & NPS & \\
\hline$>$ 80,000 km ${ }^{2}$ & BLM & \\
\hline Wood Tikchik State Park & State of Alaska & \\
\hline Eastern Bering Sea & & Appendix 16 \\
\hline
\end{tabular}

The primary agents linking climate and geology in western Alaska, and thereby providing the template for ecosystem structure, are (1) freshwater flows from upland areas and the Alaska interior, (2) permafrost distribution, and (3) sea-ice effects on coastal depositional landscapes. Freshwater flow to this region originates in small headwater streams and from large rivers such as the Yukon, Kuskokwim, and Kobuk Rivers. Flow has geomorphic consequences (e.g., channel migration, delta formation) through the erosion, transport, and deposition of sediment, with impact depending on flow volume and duration. Sediment and contaminant content, as well as hydrograph characteristics, determine the quality of aquatic habitat for many species, and the nature of estuarine dynamics (Brabets and others, 2006).

All of the Bering Coast Ecoregion experiences some degree of permafrost influence. Specifically there exists a north-to-south gradient of spatial distribution of permafrostfrom continuous, to discontinuous, to sporadic (Brown and others, 1998; Jorgenson and others, 2008). By creating an

Table 7. Summary of elements included in refuge-specific terrestrial models from the Bering Coast Ecoregion and eastern Bering Sea marine model, and description of representation of elements in ecoregional model.

[See table 6 for location of fine-scale models. See figure 10 for elements in the ecoregional model]

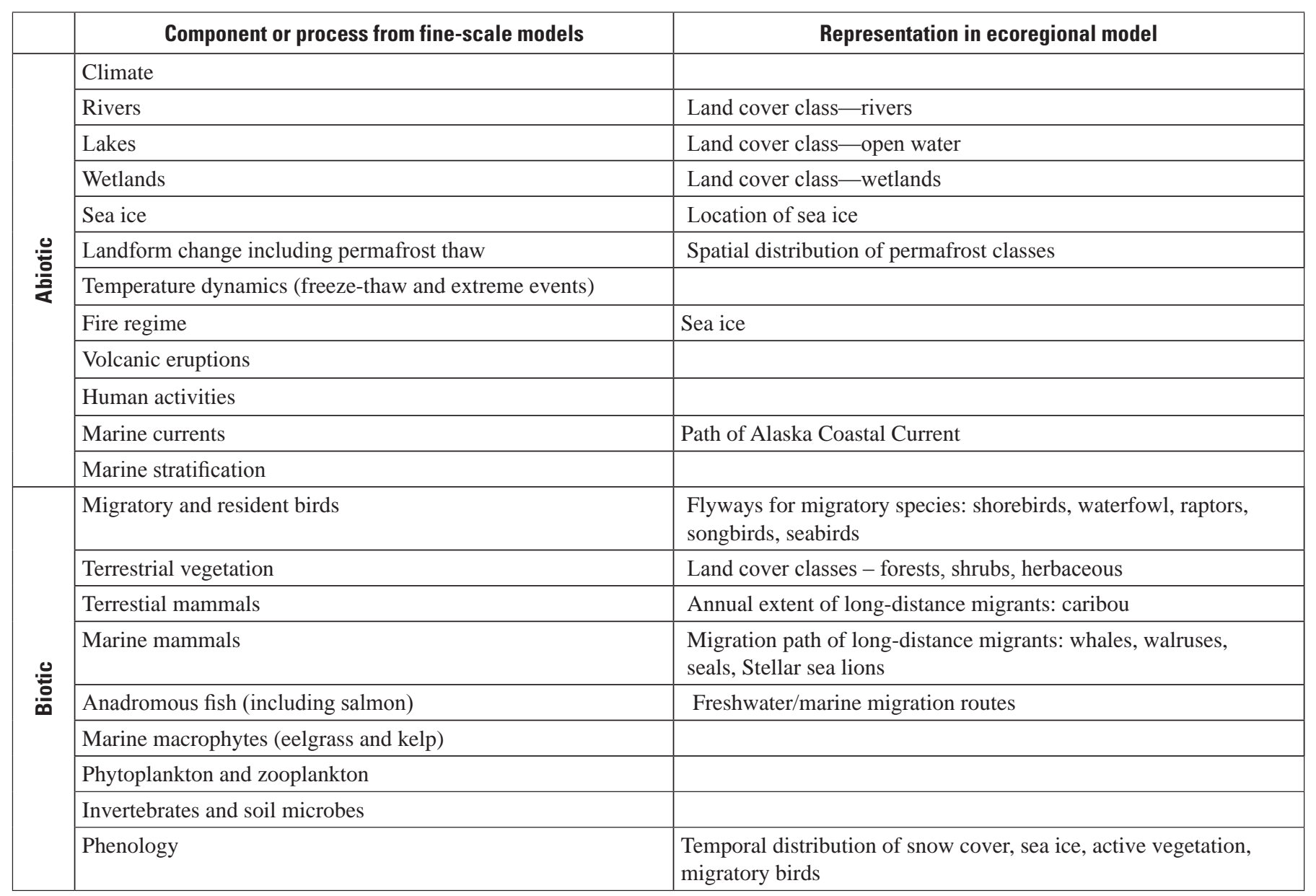


Table 8. Summary of weather statistics for the Bering Coast Ecoregion.

[From Shulski and Wendler (2007). Records are based on 11 stations for 1971-2000. \%, percent; ${ }^{\circ} \mathrm{C}$, degrees Celsius; days/yr, days per year; mm, millimeter; cm, centimeter]

\begin{tabular}{|l|c|}
\hline \multicolumn{1}{|c|}{ Weather variable } & Range across stations \\
\hline Mean annual temperature & -6 to $+2^{\circ} \mathrm{C}$ \\
\hline Mean July high temperature & 11 to $19^{\circ} \mathrm{C}$ \\
\hline Mean January low temperature & -9 to $-23^{\circ} \mathrm{C}$ \\
\hline Period below freezing & 169 to 256 days/yr \\
\hline Mean annual precipitation & 254 to $661 \mathrm{~mm}$ \\
\hline Mean annual snowfall & 62 to $228 \mathrm{~cm}$ \\
\hline Median snow period & $\begin{array}{c}\text { October } 7 \text { to May } 16 \text { (Nome) } \\
\text { October } 17 \text { to May } 2 \text { (King Salmon) }\end{array}$ \\
\hline $\begin{array}{l}\text { Mean number clear days (0-30\% cloud cover) - } \\
\text { King Salmon, Bethel, Kotzebue, Nome }\end{array}$ & 50 to 100 days/yr \\
\hline
\end{tabular}

impermeable barrier to water drainage and soil moisture, permafrost determines the distribution of wetlands and lakes and the growing conditions for vegetation (Bonan and Shugart, 1989).

Sea ice forms along the entire west coast of mainland Alaska, but not along the Aleutian Islands nor on the southern side of the Alaska Peninsula. It has a role in determining local weather, by increasing albedo and thus reducing the transfer of incident solar energy from the atmosphere to the ocean when ice is present (Shulski and Wendler, 2007). Furthermore, in winter, greater continuity of sea ice results in colder air temperatures. Sea ice also protects the coastline from erosion and saltwater inundation due to storm surges, especially if the ice forms in time to protect coastal ecosystems against the severe autumn and early-winter storms. The thickness, continuity, and snow cover, which affects albedo, of sea ice is determined by complex dynamic and thermodynamic interactions among ocean, atmosphere, and the ice itself (Clement and others, 2004; Shulski and Wendler, 2007).

Physiography, climate, and water transport drive ecosystems of the East Bering Sea marine ecoregion (appendix 16). Bathymetrically, the eastern Bering Sea is characterized by a broad $(>500-\mathrm{km})$ continental shelf consisting of three domains that can be described by depth ranges (i.e., coastal, < $50 \mathrm{~m}$ deep; middle shelf, $50-100 \mathrm{~m}$ deep; outer shelf, 100-200 m deep) and a much deeper basin to the west (>350 m deep, Stabeno and others, 2001). However, Piatt and Springer (2007; fig. 7) divide the coastal domain into a coastal and an inner domain; the coastal part is defined by low-salinity Alaska Coastal Current water closer to shore. Water circulation is driven by northward currents, tidal flow, and vertical mixing due to wind (Stabeno and others, 1999, 2008). The interactions among these factors (including ice) determine water stratification, ice dynamics, and water temperature, which in turn drive productivity and structure of the food web (Napp and Hunt, 2001).

Freshwater delivery from inland rivers into the marine environment is important because the marine environment in this ecoregion is very shallow (Buckley and others, 2009). Consequently, this allows freshwater lenses to reach far into the ocean, where they feed into the freshwater-driven Alaska Coastal Current that originates in the Gulf of Alaska and eventually enters the Chukchi Sea.

\section{Ecoregional Biotic Processes and Components}

The Bering Coast Ecoregion includes large expanses of river delta, which provide many types of freshwater- and brackish wetlands, shrublands, tussock and shrub tundra, riparian shrublands, and some spruce (Picea glauca and $P$. mariana), poplar (Populus balsamifera and P. tremuloides), and birch (Betula spp.) forests (fig. 10). A significant portion of Togiak NWR is in the Ahklun Mountains, where shrub and forested lands are relatively more abundant. Freshwater, estuarine, and saltwater aquatic environments, as well as coastal cliffs and beaches, also are important habitats for diverse wildlife species. Because the growing season and availability of these habitats are extremely short and productive, the habitats are used by a large number of longdistance migrants.

A great diversity of migratory species use the Bering Coast Ecoregion. Long-distance terrestrial migrants that range outside the boundaries of individual refuges include members of the Mulchatna and Western Arctic Caribou Herds, among other smaller herds (Davis and others, 1980; 
Hinkes and others, 2005). In addition, migratory birds from North and South America, Australasia, Oceania, Africa, and Antarctica depend on this area for breeding and feeding grounds, especially along the coast (Gill and others, 1994; Boere and others, 2006; Alerstam and others, 2007). Several marine mammal species migrate along the coast. Beluga whales tend to stay close to the shore and sometimes enter estuaries. Walruses, primarily females and calves, migrate from the Bering Sea to the southern edge of ice in the Chukchi Sea in spring, and return to the Bering Sea as ice forms in the autumn. Gray whales migrate along the coast between calving and feeding grounds (Tynan and DeMaster, 1997). In addition, five salmonid species use the river drainages of western Alaska for spawning and rearing, and then migrate to the Bering Sea and North Pacific for long periods of growth (Farley and others, 2005; Krueger and Zimmerman, 2009).

The Bering Sea is a transition zone between the colder water and drier climate of the Arctic and the warmer waters and moist maritime climate of the Pacific to the south (Overland and Stabeno, 2004). Consequently, it is one of the world's most productive marine ecosystems (Walsh and others, 1989), especially in the middle shelf and outer shelf domains (Springer and others, 1996). The ecosystem currently provides 47 percent of the U.S. fishery production by weight, and is home to 80 percent of the U.S. seabird population, 95 percent of northern fur seals (Callorhinus ursinus), and major populations of Steller sea lions (Eumetopias jubatus), walruses, and whales (Overland and Stabeno, 2004).

Human activities also impact the Bering Coast

Ecoregion. Although individuals tend to have local impacts, the commercial fishing industry has ecoregional-scale impacts on marine resources. Point sources of contaminant release also can potentially be spread over large areas in flowing rivers.

\section{Potential Effects of Global Change}

Principal effects of climate change on abiotic ecosystem components and processes include permafrost thaw, and changes to properties of sea ice, shorefast ice, and storm surges. Permafrost thaw could induce a positive feedback loop to climate change due to the consequent release of methane (Zimov and others, 1997; Walter and others, 2006; Euskirchen and others, 2009) and could change the distribution and abundance of wetlands. Changes in accumulation of sea and shorefast ice, affect coastal erosion and stratification of the marine water column (Grebmeier and others, 2006). Storm surges, when combined with sea-level rise, not only result in coastal erosion, but also in sediment deposition and changes in water salinity across broad expanses of the Yukon-Kuskokwim Delta (Mason and others, 1996; Jorgenson and Ely, 2001). The seasonality of storms is predicted to shift with climate change (Walsh and others, 1996; Serreze and others, 1997). In fact, storm surges during avian breeding seasons have become more frequent, causing significant losses of chicks and eggs for coastal-breeding birds (Wise and others, 1981; Person and others, 2003), loss of avian breeding habitat (Ely and others, 1994). Moreover, storm surge-related reductions in vole, lemming and muskrat (Ondatra zibethicus) populations, lead to changes in trophic relationships (Brabets and others, 2006).

Ecosystems of the Bering Coast Ecoregion are vulnerable to distant as well was local effects of global change. Thermokarst events and the timing and distribution of ice melt in upstream regions of the Yukon, Kuskokwim, and Kobuk Rivers will affect flow dynamics, erosion and sedimentation downstream, ultimately producing consequences for riparian habitat and channel structure (Beltaos and Burrell, 2003). Moreover, spawning habitat quality upstream of the coast affects the health of anadromous and potamodromous fishes that are food resources for those marine mammals inhabiting coastal areas. At greater distances, the Bering Coast Ecoregion is linked to climate effects through the fitness and timing of migrant bird species, with changes potentially causing the loss of synchrony between resource availability and migration (Visser and Both, 2005). In addition, atmospheric contaminants are carried by the global circulation system from Asia to western Alaska (Prospero and Savoie, 1989; Jaffe and others, 2003). This process which will likely increase with further economic development in Asia.

As warmer temperatures and increased rates of evaporation create drier conditions in terrestrial ecosystems, fire is expected to become an increasingly important disturbance in the Bering Coast Ecoregion. Because fire exposes mineral soils and releases nutrients, shrubs may increase, thus creating a positive-feedback loop of increasing fire frequency (Racine and others, 2004). The effects of fire on vegetation composition reflect not only fire severity, but also two other factors that also reflect climate (Verbyla and Lord, 2008) - site moisture and pre-fire vegetation (Johnstone and others, 2008). These vegetation changes, in turn, will affect the distribution and abundance of animals (Jorgenson and Ely, 2001).

In the marine environment, global change is causing a northward biogeographic shift in the Bering Sea that will have major effects on commercial and subsistence fish harvests. Distribution of productivity to different levels of the food chain depends on the timing of ice retreat (see appendix 16 for more detail). In brief, warmer climate may favor fish over piscivorous birds and mammals; this shift would likely have consequences for aquatic long-distance migrants. Additionally, increasing atmospheric $\mathrm{CO} 2$ is associated with acidification of marine waters may lead to impairment of animals that have calcareous shells (Orr and others, 2005). Marine food webs also are impacted by harvest and introduction of exotic species. 


\section{Interior Alaska Ecoregional Model}

\section{Geographic Context}

The Interior Alaska Ecoregion is the largest ecoregion, covering the central part of Alaska south of the Brooks Range, and including the Alaska Range, the Wrangell Mountains, and the Cook Inlet and Copper River Basins (fig. 11). It is composed of 15 of the 32 unified ecoregions (Nowacki and others, 2001). Other significant geographic features include the broad valleys of the Yukon and Tanana Rivers and the largest urban areas in Alaska-Anchorage and Fairbanks.

Land management units in the Interior Alaska Ecoregion are shown in table 9 . A summary of the components and processes identified in relevant refuge-specific models and the ecoregional dimension for those that operate at the ecoregional scale are shown in table 10.

\section{Ecoregional Abiotic Processes and Components (see Brabets and others, 2006)}

Shulski and Wendler (2007) describe most of the Interior Alaska Ecoregion (their Interior and Copper River Basin regions) as typified by a continental climate, resulting in large temperature variability; light and irregular precipitation; warm, sunny summers; and very long, cold winters (table 11). The region has warmer average temperatures than the Polar Ecoregion but has colder winters and hotter summers than other parts of Alaska. Wide temperature swings in winter are caused by frequent low-level temperature inversions when skies are clear and winds are calm, and by Chinook winds created when warm Pacific air moves over the Alaska Range. Precipitation falls mostly in summer in the form of sporadic showers or thunderstorms, due to local convective processes early in the summer, and organized frontal systems from the southwest later in the summer. The driest locales of Alaska are the broad river valleys of the Interior.

The southwest part of the Interior Alaska Ecoregion (i.e., the Cook Inlet region of Shulski and Wendler, 2007) is a transition zone between the maritime climate of the southern coast and the continental climate of the interior. As such, the area experiences more moderate temperatures, a longer growing season, higher precipitation, and higher winds than the rest of the ecoregion.

The physical template for the Interior Alaska Ecoregion includes both mountainous and lowland areas (fig. 11). Although the ecoregion has a continental climate, precipitation in mountainous areas can be similar to that in maritime climates, creating glaciers in some places. Lowland areas are typified by ponds, thaw and oxbow lakes, wetlands, and large rivers. As in most other parts of Alaska, the physical template reflects the presence of permafrost. Lowland areas are typically underlain by discontinuous permafrost, whereas unglaciated areas within mountains may have discontinuous, sporadic, or no permafrost (Brown and others, 1998; Jorgenson and others, 2008). In this ecoregion, permafrost is important because it determines the likelihood of flash floods and it influences summer peak flow.

Several large rivers, including the Yukon River and its tributaries the Kuskokwim, Tanana, and Kobuk, and Copper River, drain 823,700 km² of the Interior Alaska Ecoregion and parts of Canada. Three hydrographic patterns occur in various parts of the watershed: lake runoff in areas where snowmelt, rainfall and ice melt combine to fill lakes, which then run over in August and September; snowmelt runoff which occurs during a fairly short period in June; and glacier runoff, which is sustained over the summer. The cumulative runoff pattern for the Yukon River is a peak flow in June that tapers monotonically to November. Seasonal flooding is a by-product of annual ice formation on rivers, and renews adjacent wetlands and riparian areas with a fresh supply of water, nutrients and sediments. Severe floods also can damage spawning beds and wash fish out of the river.

The Yukon River moves approximately 60 million tons of sediment per year; 20 million of which are deposited in floodplains of the river. This process is seasonal, occurring during May to September and reflecting the hydrograph. Sediment transport can affect aquatic life and also may transport contaminants that adhere to particles. Sources of pollutants include global transport from mid-latitudes (Kidd and others, 1995; MacDonald and others, 2000), past mining activities (e.g., Coal Creek Superfund site) and refuse from military activities during the Cold War.

Wildfire burns $4,000 \mathrm{~km}^{2} / \mathrm{yr}$ statewide on average, mainly in the interior. Ninety percent of the area is burned by fires started by lightning, especially in early to midsummer when precipitation is light (Kasischke and others, 2002; Shulski and Wendler, 2007). Fire can affect hydrology by affecting permafrost; fire also also increase carbon release to rivers and the atmosphere.

\section{Ecoregional Biotic Processes and Components}

Vegetation in the Interior Alaska Ecoregion is a mosaic of boreal forest, shrubland, tundra, riparian areas, and wet meadows of varying composition and successional stage. The pattern reflects the relatively static features of elevation and permafrost distribution, and the dynamic processes of fire and flooding, which remove vegetation and return nutrients to the soil.

The diversity of habitats is home to a variety of migratory species and species that have large home ranges that may cross refuge boundaries. Migratory birds arrive from North and South America, Asia, Australia, Africa, and Antarctica, and include many species of raptors, passerines, waterfowl, shorebirds, and other waterbirds (Deppe and others, 2007). 


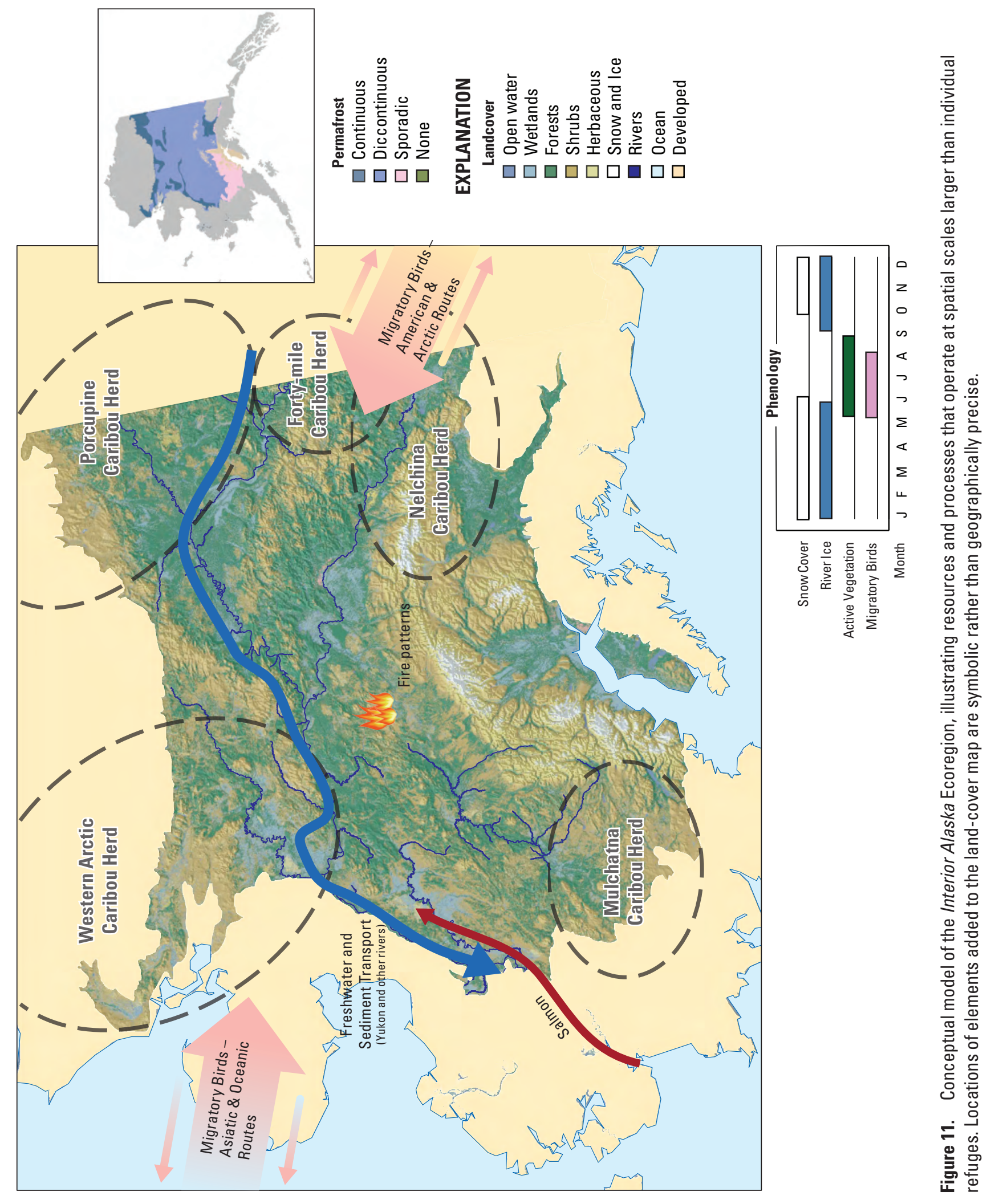


Table 9. Wildlife refuges and land-management units of other agencies included in the Interior Alaska Ecoregion.

[L and unit: NWR, National Wildlife Refuge; NM, National Monument; NP, National Park. Agency: BLM, U.S. Bureau of Land Management; NPS, U.S National Park Service; USFWS, U.S. Fish and Wildlife Service. Fine-scale conceptual model: Only models included in this document are listed. See http://science.nature.nps.gov/im/monitor for conceptual models of National Park Service (NPS) units. km², kilometer; >, greater than]

\begin{tabular}{|c|c|c|}
\hline Land unit & Agency & $\begin{array}{c}\text { Fine-scale } \\
\text { conceptual model }\end{array}$ \\
\hline Arctic NWR & USFWS & $\begin{array}{c}\text { (None for Interior Alaska } \\
\text { portion) }\end{array}$ \\
\hline Innoko NWR & USFWS & Appendixes 4 and 7 \\
\hline Kanuti NWR & USFWS & Appendix 5 \\
\hline Kenai NWR & USFWS & Appendix 6 \\
\hline Koyukuk NWR & USFWS & Appendix 7 \\
\hline Nowitna NWR & USFWS & Appendix 7 \\
\hline Selawik NWR & USFWS & Appendix 8 \\
\hline Tetlin NWR & USFWS & Appendix 9 \\
\hline Yukon Flats & USFWS & Appendix 10 \\
\hline Cape Krusenstern NM & NPS & \\
\hline Denali NP & NPS & \\
\hline Kobuk Valley NP & NPS & \\
\hline Lake Clark NP & NPS & \\
\hline Noatak NP & NPS & \\
\hline Wrangell-St. Elias NP & NPS & \\
\hline$>100,000 \mathrm{~km}^{2}$ & BLM & \\
\hline
\end{tabular}

The area also is used by the Mulchatna, Western Arctic, Porcupine, Forty-mile, and Nelchina Caribou Herds, among others. Caribou generally winter south of the Brooks Range and migrate to the northern coastal plains and foothills, where food is nutritious and predators are few, to calve. Snow depth in the winter range and along the migration route, as well as timing of spring melt affect the success of this strategy. Weather, especially air temperature and wind speed, also determines the impact of mosquitoes, which can interfere with feeding and weaken animals due to blood loss and mosquitoborne diseases. Caribou use different portions of the range each year, thereby spreading grazing impact on vegetation (see Fancy and others, 1989; Cameron and others, 2002).

Anadromous fish using the ecoregion include Chinook (king, Onchorhynchus tshawytscha), chum (Onchorhynchus keta), and coho (silver, Onchorhynchus kisutch) salmon, as well as sheefish (Stenodus leucichthys); annual salmon runs constitute millions of individuals. In addition to contributing nutrients to the aquatic and riparian environments, the abundance of anadromous fish can structure other parts of the food web. For example, salmon abundance can mediate competition between brown (Ursus arctos) and black bears (Ursus americanus), thereby determining the reproductive success of black bears (Belant and others, 2006). Salmon also may significantly supplement wolf diets in some areas, thereby supporting larger wolf populations, which in turn increase predation pressure on ungulates (Adams and others, 2010).

\section{Potential Effects of Global Change}

In the Interior Alaska Ecoregion, the predicted abiotic effects of climate change will most notably impact hydrology and fire. Potential consequences of climate change include increases in sediment load due to higher frequency of thermokarst events and changes in flow regime due to changes in timing of ice melt (Toniolo and others, 2008). Moreover, there are large mountainous areas covered by ice fields within this region. Hydrologic changes due to melting glacier will potentially affect Kenai NWR, which is partially covered by the Harding Ice Field, and other refuges that have glaciers outside of their boundaries (e.g., Yukon Flats NWR, Tetlin NWR). Most forecasts of future climate suggest that fire will further increase in frequency and intensity in the coming years within the ecoregion (Rupp and others, 2002). Consequently, the effects of fire on permafrost, air quality, successional processes and vegetation structure seen in recent decades may be expected to become more dramatic.

The mosaic of landcover types and successional stages in the Interior Alaska Ecoregion has the potential to change in direct response to changing climate, for example through reduced photosynthesis and altered carbon allocation in plants (Verbyla, 2008). Changes also may occur indirectly as vegetation responds to climatic effects on: hydrology (including degradation of permafrost [Riordan and others, 2006]), fire regime, spread of disease and pathogens (Hennon and Shaw, 1997), and evapotranspiration (Riordan and others, 2006). Changes in some areas may counteract changes in others, such that habitat availability for migratory birds cannot be understood by solely examining the changes in any one land unit. For example, the loss of wetlands due to drying in some areas (Vitt and others, 2000; Riordan and others, 2006) may be balanced by an increase in wetlands due to thawing permafrost (Osterkamp and others, 2000; Jorgenson and others, 2001) elsewhere. 
Table 10. Summary of elements included in refuge-specific terrestrial models from the Interior Alaska Ecoregion, and description of representation of elements in ecoregional model.

[See table 9 for location of fine-scale models. See figure 11 for elements in the ecoregional model]

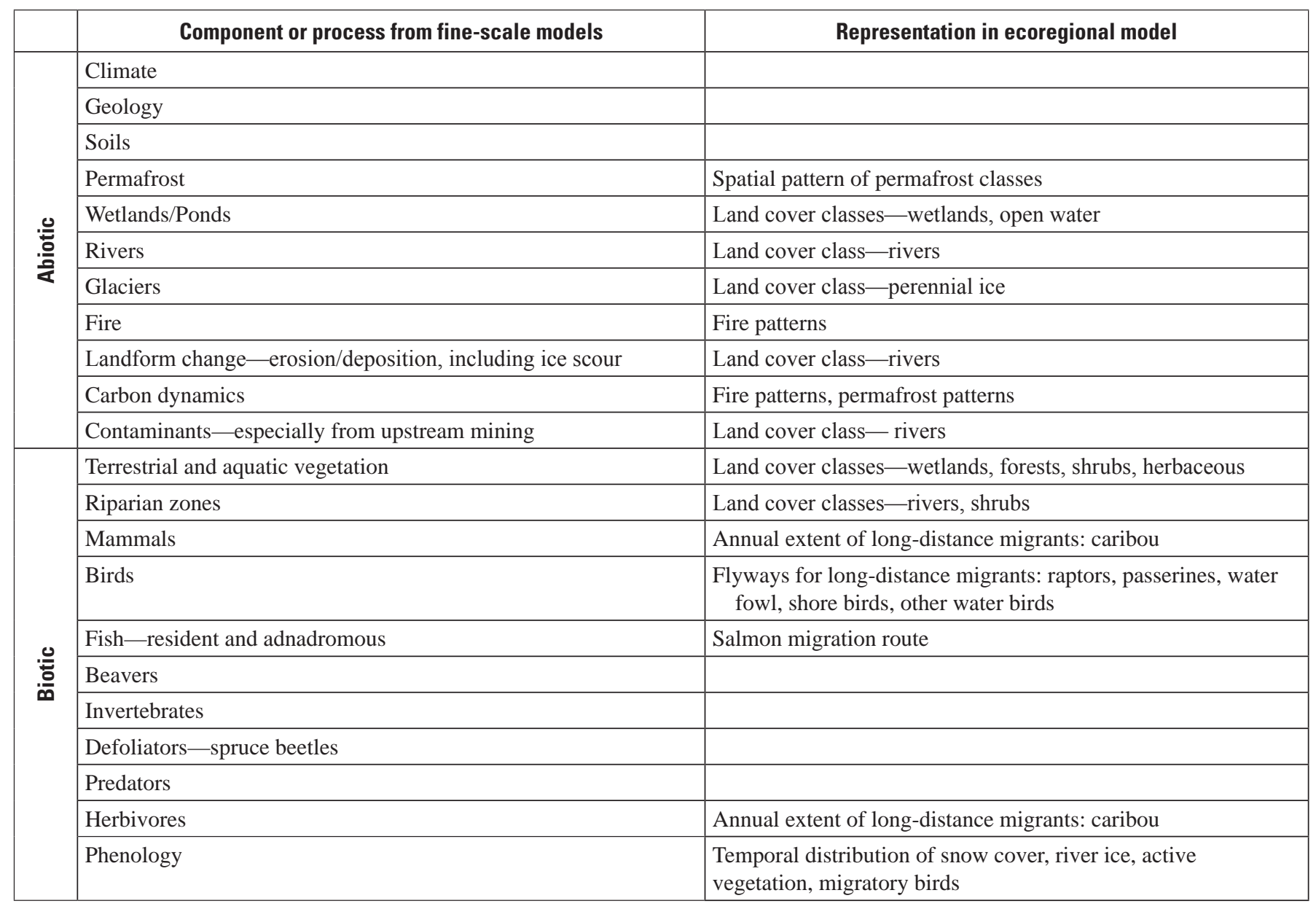

Table 11. Summary of weather statistics for the Interior Alaska Ecoregion.

[From Shulski and Wendler, 2007. Records are based on 38 land-based stations for 1971-2000. \%, percent; ${ }^{\circ} \mathrm{C}$, degrees Celsius; mm, millimeter; $\mathrm{cm}$, centimeter; days/yr, days per year]

\begin{tabular}{|l|c|}
\hline \multicolumn{1}{|c|}{ Weather variable } & Range across stations \\
\hline Mean annual temperature & -8 to $+3^{\circ} \mathrm{C}$ \\
\hline Mean July high temperature & 16 to $28^{\circ} \mathrm{C}$ \\
\hline Mean February low temperature & -31 to $-8^{\circ} \mathrm{C}$ \\
\hline Period below freezing & 179 to 276 days/yr \\
\hline Mean annual precipitation & 218 to $716 \mathrm{~mm}$ \\
\hline Mean annual snowfall & 84 to $509 \mathrm{~cm}$ \\
\hline Median snow period & $\begin{array}{c}\text { October } 16 \text { to April } 17 \text { (Anchorage) } \\
\text { October } 2 \text { to April } 23 \text { (Fairbanks) } \\
\text { October } 7 \text { to April } 16 \text { (Gulkana) }\end{array}$ \\
\hline Mean clear days (0-30\% cloud cover) -7 stations & $61-69$ days/yr \\
\hline
\end{tabular}


Abiotic and biotic processes also may intersect to create phenological mismatches in the synchrony among animal migrations and primary and secondary productivity, including vegetation and insect emergence, as have already had significant effects at times on bird populations in Europe (Visser and others, 1998; Stenseth and Mysterud, 2002). These mismatches are responsive to climate change through the phenology of snow and ice melt, flooding of rivers, temperature, and precipitation, and may cause animal distributions to shift in latitude or elevation. Moreover, the timing and routes of migration are dependent upon climatic conditions at a hemispheric scale, such that changes in atmospheric conditions could have significant consequences for migrant birds that exploit global wind patterns in their migration strategies (Gill and others, 2009).

The Interior Alaska Ecoregion may play an important role in affecting global atmospheric carbon concentrations. Carbon may be released as a warming climate causes thawing of permafrost and increased incidence of fires (Kasischke and others, 2005). The magnitude of this release is unknown, although the potential is great (Walker, 2007). Conversely, carbon may be increasingly sequestered if vegetation response to changing climate includes an increasing extent of boreal forests (Keyser and others, 2000). Magnitude and direction of changes will vary across the region, but the net effect will likely have global impact.

While acknowledging that Alaska has a very small human population relative to global norms, the Interior Alaska Ecoregion hosts the largest human population in the state, and it is most likely to be most affected by human population in the next 50 years. Impacts will come from activities on in-holdings, increased harvest, recreational activities, and extraction of resources.

\section{North Pacific Coast Ecoregional Model}

\section{Geographic Context}

The North Pacific Coast Ecoregion extends along the southern border of Alaska from the coastal rainforests of southeast Alaska westward through the Aleutian Islands (fig. 12). Geologically, the area is a volcanic zone resulting from the tectonic collision of the Pacific Plate with the North American Plate. The entire ecoregion is strongly influenced by currents and weather generated in the Gulf of Alaska and by freshwater runoff; the western part of the region also is impacted by conditions in the Bering Sea to the north.

The marine area associated with the North Pacific Coast Ecoregion is the portion of the northern Pacific Ocean from the Gulf of Alaska in the east to the Aleutian Islands. This area includes the Gulf of Alaska and part of the East Bering Sea PBCRs (fig. 3), and corresponds to marine ecoregions 1 through 13 (Piatt and Springer, 2007; table 3). This marine area is fed by many small rivers in addition to the Susitna and Copper Rivers. It is largely ice-free, except for periods each year when some protected embayments and inlets freeze. The Aleutian Island Unit of Alaska Maritime NWR and Izembek NWR border both the North Pacific and the Bering Sea. The Gulf of Alaska Unit of Alaska Maritime NWR and Alaska Peninsula, Becharof, Kodiak, and Kenai NWRs border only the North Pacific.

Land management units in the North Pacific Coast Ecoregion are shown in table 12. With the exception of a few hundred hectares of the Alaska Maritime NWR on islands in the Alexander Archipelago off the coast of southeast Alaska, the national wildlife refuges all are in the western part of the ecoregion. A summary of the components and processes identified in relevant refuge-specific conceptual models and the ecoregional dimension for those that operate at the ecoregional scale are shown in table 13.

\section{Ecoregional Abiotic Processes and Components}

The climate of the North Pacific Coast Ecoregion is strongly influenced by the proximity of the Pacific Ocean, and is typified by more-moderate diel and seasonal temperature fluctuations and higher precipitation than other portions of Alaska (table 14, Shulski and Wendler, 2007). Across longer time frames, broad-scale climatic cycles (e.g., Arctic Oscillation, Pacific Decadal Oscillation, El Nino/Southern Oscillation) contribute to climate variation across years and decades. As with all of Alaska, the locations of Aleutian Low and Arctic High pressure systems are driving forces for the weather in this region. Future-climate scenarios indicate that the Aleutian Low will tend to have a more northerly track with continued climate warming (McCabe and others, 2001; Salanthé, 2006). Rainfall and relative humidity in this ecoregion are much higher than in the rest of the state, due to the intersection of moist temperate westerlies from the Pacific Ocean with mountainous terrain. The steep topography also affects air temperature so that a universal characteristic of the ecoregion is a relatively fine-scaled gradient in climate.

The relationship of ambient conditions to the freezing point of water is vitally important for ecological dynamics, and the annual temperature within this ecoregion averages near $0^{\circ} \mathrm{C}$. Near-constant wetness (especially in the eastern portion of the ecoregion) and cool temperatures drive the development of organic, poorly drained soils (Heilman and Gass, 1974). Local and long-distance transport of water-via fog, precipitation and runoff patterns, snow and permafrost storage and thawing, and groundwater recharge - connect areas within the ecoregion. Intense winds are frequent and create gradients of salinity and precipitation across different elevations, exposures (e.g., leeward versus windward), and distances from the coast. These winds also provide longdistance transport for point-source pollutants as well as for seeds, propagules, pests and pathogens, and migratory birds, particularly during fall migration. Winds also influence the effects that volcanic eruptions have on areas that receive their ash and other emissions. 

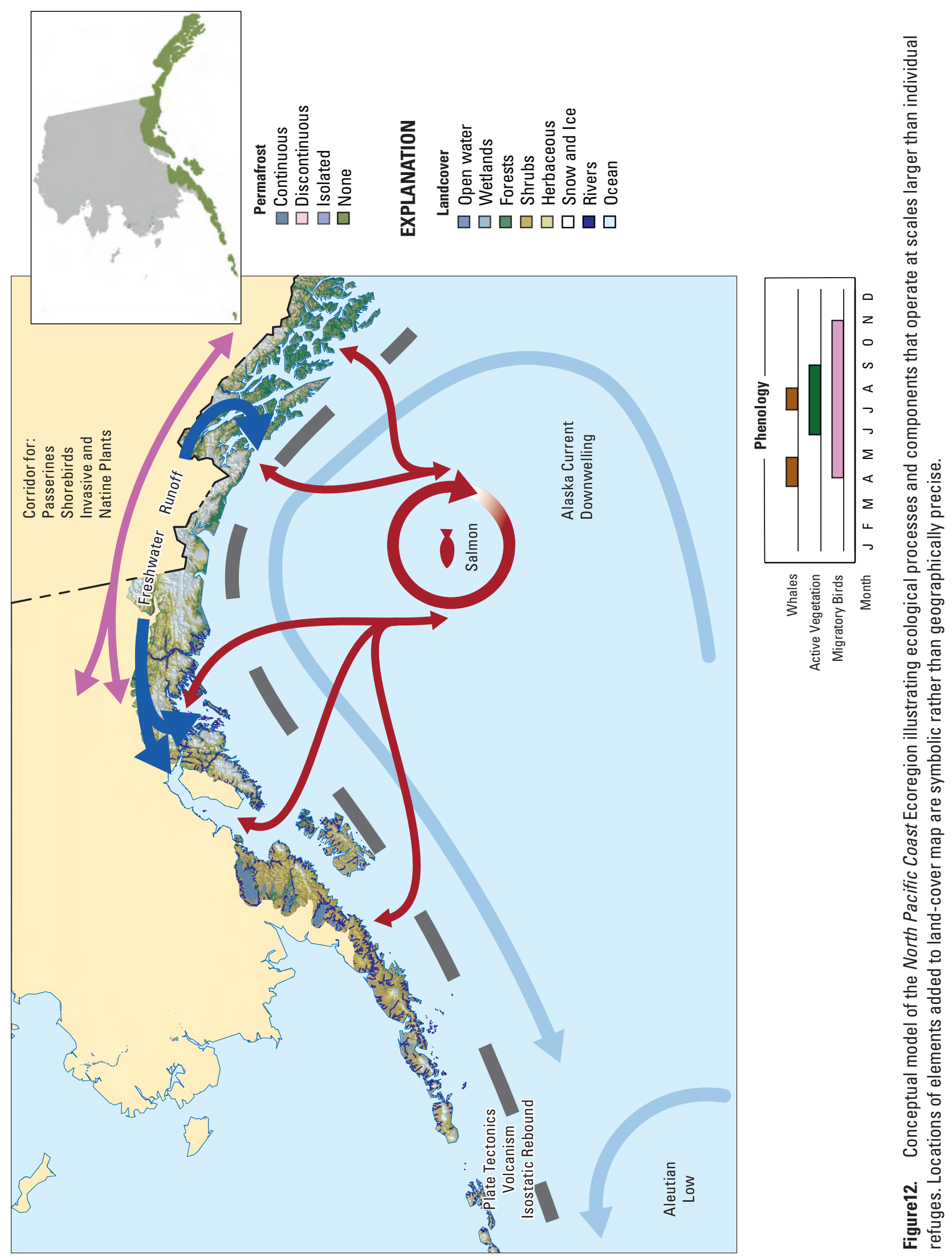
Table 12. Wildlife refuges, land-management units of other agencies, and marine region included in the North Pacific Coast Ecoregion.

[L and unit: NWR, National Wildlife Refuge; NF, National Forest; NP, National Park; NPH, National Historical Park. A gency: BIA, Bureau of Indian Affairs; NPS, U.S. National Park Service; USFS, U.S. Forest Service; USFWS, U.S. Fish and Wildlife Service. Fine-scale conceptual model: Only models included in this document are listed. See http://science.nature.nps.gov/im/

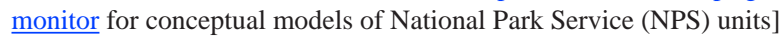

\begin{tabular}{|l|l|c|}
\hline \multicolumn{1}{|c|}{ Land/marine unit } & Agency & $\begin{array}{c}\text { Fine-scale } \\
\text { conceptual model }\end{array}$ \\
\hline Alaska Maritime NWR & USFWS & Appendix 11 \\
\hline Alaska Peninsula NWR & USFWS & Appendix 12 \\
\hline Becharof NWR & USFWS & Appendix 12 \\
\hline Kenai NWR & USFWS & Appendix 6 \\
\hline Izembek NWR & USFWS & Appendix 13 \\
\hline Kodiak NWR & USFWS & Appendix 14 \\
\hline Glacier Bay NP & NPS & \\
\hline Klondike Goldrush NHP & NPS & \\
\hline Sitka NHP & NPS & \\
\hline Annette Island Indian Reservation & BIA & \\
\hline Chugach NF & USFS & \\
\hline Tongass NF & USFS & \\
\hline North Pacific Ocean Marine area & & Appendix 17 \\
\hline & &
\end{tabular}

The collision between the North American and Pacific tectonic plates in this region creates the Aleutian island chain and coastal mountain ranges, and a consequently dramatic topographic gradient. In addition to generating orographic effects on climate and habitat distribution, these mountains also include all of Alaska's recently active volcanoes, resulting in a much higher frequency of eruptions and earthquakes in this ecoregion compared with the rest of Alaska (Schaefer and Nye, 2008). Recent examples of tectonic events include the eruption of Kasatochi Volcano in August 2008 and the 1964 earthquake, which dramatically altered the geomorphology of the region (Plafker, 1970; Prescott and Lisowski, 1977).

Other physical processes pertain to the eastern part of the ecoregion where warm, wet air from the warm Gulf of Alaska sweeps inland onto the high mountains and deposits large amounts of water, creating the largest ice sheets in North America above the freezing line, and large rivers and runoff below. Catastrophic outburst floods of glacial lakes have occurred several times in the last 120 years (Post and Mayo, 1971), producing long-lasting abiotic and biotic effects. Glacial meltwater and precipitation combine to create a volume of freshwater runoff that is greater than that of the Amazon River (Neal and others, 2010). In addition to recharging wetlands and estuaries, freshwater affects the volume, speed, and salinity of the Alaska Coastal Current, which influences the entire coast from Southeast Alaska to the north side of the Alaska Peninsula, the Bering Coast, and even the Chukchi Sea. At much longer time scales, the recovery from glacial-interglacial maxima and minima (e.g., ice scour, isostatic rebound, effects on rocky substrates, historical biogeographical effects on plant distributions) drives and constrains successional processes in this portion of the ecoregion.

Coastal dynamics, including wave action, tides, erosion, wind mixing, coastal currents, salinity, and sea level, figure prominently in coastal ecosystems of the North Pacific Coast ecoregion. Sea ice only occurs in Cook Inlet and the eastern part of the Alaska Peninsula from winter storms (Shulski and Wendler, 2007).

The continental shelf is 85 to $250 \mathrm{~km}$ wide along the south coast of Alaska and the Aleutian Islands; the narrowest extent occurs along the southeast Alaskan coast. As this is a subduction zone, the shelf drops to a depth of 4,000 to $10,000 \mathrm{~m}$ in the Aleutian Trench. Consequently, habitat and features of the North Pacific can be divided into coastal watersheds; intertidal and shallow subtidal areas; the Alaska Coastal Current, which extends up to $50 \mathrm{~km}$ from the coast; and offshore areas covered by the Alaska Stream, and the Alaska Gyre, which include the continental shelf break, the continental slope and the deep ocean (Gulf of Alaska Ecosystem Monitoring and Research Program, 2002). Important characteristics determining distribution of biota include substrate; strength and direction of currents; frontal regions; eddies; water temperature; and salinity (Piatt and Springer, 2007). Many of these factors are driven ultimately by global weather patterns such as the El Nino/Southern Oscillation and the Pacific Decadal Oscillation (appendix 17).

\section{Ecoregional Biotic Processes and Components}

Alpine tundra dominates high-elevation ice-free areas that have stable soils throughout the ecoregion, while there is an east-west gradient in vegetation at lower elevations. In the west, vegetation communities in the Aleutian Islands and Alaska Peninsula are typified by low shrubs of willow (Salix spp.), birch, and alder (Alnus crispa and A. rugosa) interspersed with ericaceous heath, lichen, and grass communities (Nowacki and others, 2001). In the east, vegetation on lands surrounding the Gulf of Alaska include temperate rainforest of hemlock (Tsuga heterophylla) and spruce (Picea sitchensis) mixed with open and forested wetlands on poorly drained soils.

The topography and location of the North Pacific Coast Ecoregion means that the ecoregion acts as a corridor for avian migrants (given its connection to both the Eastern and Western Pacific Flyways), native and invasive plants, marine mammals (e.g., gray and humpback whales, northern fur seals), as well 
Table 13. Summary of elements included in refuge-specific terrestrial models from the North Pacific Coast Ecoregion and the North Pacific Ocean marine model, and description of representation of elements in ecoregional model.

[See table 12 for locations of fine-scale conceptual models. See figure 12 for elements in the ecoregional model]

\begin{tabular}{|c|c|c|}
\hline & Component or process from fine-scale models & Representation in ecoregional model \\
\hline \multirow{7}{*}{ 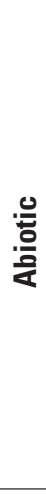 } & Terrain & Shaded-relief \\
\hline & Volcanoes & Region of active volcanism \\
\hline & Glaciers & Land cover class-snow and ice \\
\hline & Lakes/ponds & Land cover class- open water \\
\hline & Wetlands & Land cover class-wetlands \\
\hline & Estuaries & \\
\hline & Marine waters_-currents, upwelling, tides, waves & Path of Alaska Current \\
\hline & $\begin{array}{l}\text { Human activities-military legacies, infrastructure, resource } \\
\text { extraction }\end{array}$ & \\
\hline \multirow{8}{*}{ 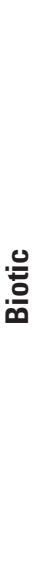 } & Primary consumers & \\
\hline & Secondary consumers & \\
\hline & Top predators & \\
\hline & Birds & $\begin{array}{l}\text { Flyway for long-distance migrants: shore birds, water fowl, } \\
\text { seabirds, passerines }\end{array}$ \\
\hline & Fish & Salmon freshwater/marine migration route \\
\hline & Invertebrates & \\
\hline & Marine benthos & \\
\hline & Phenology & Temporal distribution of whales, active vegetation, migratory birds \\
\hline
\end{tabular}

Table 14. Summary of weather statistics for the North Pacific Coast Ecoregion.

[From Shulski and Wendler (2007). Records are based on 31 land-based stations for 1971-2000.

$\%$, percent; ${ }^{\circ} \mathrm{C}$, degrees Celsius; days/yr, days per year; mm, millimeter; cm, centimeter]

\begin{tabular}{|l|c|}
\hline \multicolumn{1}{|c|}{ Weather variable } & Range across stations \\
\hline Mean annual temperature & 2 to $8^{\circ} \mathrm{C}$ \\
\hline Mean July high temperature & -10 to $20^{\circ} \mathrm{C}$ \\
\hline Mean February low temperature $0{ }^{\circ} \mathrm{C}$ \\
\hline Period below freezing & 70 to 211 days/yr \\
\hline Mean annual precipitation & 589 to $5,728 \mathrm{~mm}$ \\
\hline Mean annual snowfall & 94 to $831 \mathrm{~cm}$ \\
\hline Median snow period & $\begin{array}{l}\text { November } 6 \text { to April } 5 \text { (Juneau) } \\
\text { October } 26 \text { to April } 20 \text { (Kodiak) } \\
\text { October } 14 \text { to May } 13 \text { (St. Paul) }\end{array}$ \\
\hline Mean clear days (0-30\% cloud cover) -7 stations & $12-59$ days/yr \\
\hline
\end{tabular}


as anadromous fishes. For example, Izembek and Alaska Peninsula NWRs serve as staging and stopover areas for large numbers of migratory shorebirds, waterfowl, and a few passerine species traveling between Alaska and Asia, Africa, North and South America, or Oceania. Moreover, terrestrial animals (e.g., ungulates, carnivores) also make seasonal movements that cross refuge boundaries.

Several other broad-scale biotic phenomena and processes affect the flow of organisms and energy, as well as the relationships among ecosystem components. Nutrients move across the ecoregion via marine upwellings, ocean currents, anadromous fishes, and wide-ranging herbivores and other consumers. Patterns of vascular and nonvascular vegetation affect distributions of herbivores as well as macronutrients. Outbreaks of pests and disease are pronounced in this ecoregion; exhibit strong heterogeneity in both space and time; and can result in dramatic effects on landscape and habitat structure, composition, and function (Reynolds and Hard, 1991; Hennon and Shaw, 1997; Allen and others, 2006).

Human activities influence ecosystem dynamics across the region. Fisheries management and transport of pollutants (e.g., oil spills such as that created by the Exxon Valdez accident) and invasive species via airborne, freshwater, and marine pathways can influence various levels of marine food webs. Other forms of resource extraction, including commercial, subsistence, and sport harvest, occur across the region. Logging is more pervasive in this ecoregion than in any other part of the state. Logging may affect the balance of carbon and nitrogen, other nutrient dynamics, as well as localand meso-scale climate and habitat value for various species via altered in-stream temperatures or increased siltation due to runoff from road networks.

During the warm phase of the PDO, intensification of the Aleutian Low and consequent stronger westerly winds create warmer waters, which allow an earlier phyto- and zooplankton bloom. This timing favors recruitment of Pollock (Theragra chalcogramma), halibut (Hippoglossus stenolepis), and other predatory fish over forage fish (Anderson and Piatt, 1999). The combination of poorer food supplies for larvae and greater predation by other fish may reduce the supply of forage fish for birds and mammals. Instead, they are forced to consume lower-quality diets such as juvenile pollock. However, the warm phase is advantageous for salmon, perhaps due to increased phyto- and zooplankton production (Anderson and Piatt, 1999).

In addition to the flow of freshwater and sediments, coastal watersheds are linked to the ocean by the return of marine-derived nutrients. These primarily are carried by returning anadromous fish and enter the terrestrial system through consumption and decay of fish carcasses. Marine nutrients are also carried by seabirds and excreted in nesting areas (Gulf of Alaska Ecosystem Monitoring and Research Program, 2002).

\section{Potential Effects of Global Change}

Potential abiotic changes to the North Pacific Coast Ecoregion resulting from climate change are most notably linked to glacier melt and consequent change to freshwater quality and quantity (Meier and Dyurgerov, 2002; Chen and others, 2006). Altered isostatic rebound due to loss of glacier mass may interact with sea level rise to affect shoreline dynamics.

As elsewhere in Alaska, climate change is expected to cause changes in plant community structure, composition, and successional pathways, as well as altered dynamics of disease. Invasive species are expected to increase as are more extensive and more frequent bark beetle (Dendroctonus rufipennis and Ips spp.) infestations (Hennon and Shaw, 1997; Berg and others, 2006). Changes in habitat and direct effects of climate are predicted to alter abundances of various seabird species (Dragoo and others, 2003). Northward extensions of species' geographic ranges also are expected to alter community dynamics across the ecoregion (Munkenmiller and others, 2009), as has already been observed across North America (e.g., Sanford, 2002; Parmesan, 2006; Jannett and others, 2007). Ecological relationships, and ultimately community composition, are expected to change due to differing changes in the timing of life-cycle events among organisms and resultant trophic mismatches, as described in northern latitudes by Post and Forchhammer (2008) and Post and others (2008).

Changing climate could have a number of impacts on the marine ecosystem of the North Pacific. Changes in location and timing of weather patterns will affect currents, upwellings, and water column stability and mixing. Changes in amount of precipitation and temperature will affect freshwater runoff from rain, snow melt, and glacier melt, all of which could have dramatic effects on nearshore marine conditions. Specifically, freshwater drives the Alaska Coastal Current, which flows as far north as the Chukchi Sea (Piatt and Springer, 2003). Changes in the timing and amount of the plankton bloom, which reflect both ocean properties and weather, will profoundly affect the marine biological community. Finally, increased concentrations of atmospheric carbon dioxide have led to $\mathrm{pH}$ increases of 0.1 units in marine waters worldwide (Intergovernmental Panel on Climate Change, 2007; Tans, 2009) and high-latitude regions are predicted to experience the greatest changes in carbonate chemistry (Fabry and others, 2008). Concern exists that further acidification may more seriously affect the ability of marine organisms with exoskeletons to lay down a calcium carbonate-based shell.

Climate changes may not act in isolation, but instead may interact with other anthropogenic forces to potentially change the biologic and economic productivity of the Gulf of Alaska (Gulf of Alaska Ecosystem Monitoring and Research Program, 2002). Effects of fish harvest on populations of target species and by-catch may be influenced by the phase of the PDO. Recreation, sport fishing, and shoreline development may 
potentially impact intertidal and subtidal habitats, as may any pollutants and refuse that make landfall. Pollutants and refuse from shipping traffic and international industrial fishing also can be spread along the coast by the Alaska Coastal Current (e.g., oil from the Exxon Valdez) and from more than 300 km away by the Alaska Current (Gulf of Alaska Ecosystem Monitoring and Research Program, 2002).

\section{Synthesis}

The ecoregional and refuge-specific models presented in this report identify important ecological components and processes that can inform development of collaborative monitoring efforts among refuges and with units of other agencies. Here, we briefly summarize themes that emerged from the refuge and ecoregional models.

\section{Refuge-Specific Conceptual Models}

All refuge models included climate, geology, and trophic dynamics as fundamental to the structure, function, and composition of each refuge's ecosystem. Waterbirds and large mammals were ubiquitously important. Topics whose emphasis varied among refuges within ecoregions included diseases, pests, and contaminants. Invasive species were commonly mentioned.

\section{Ecoregional Models}

In addition to the ecosystem components shared across refuges, certain ecoregional processes also were common among the refuge-specific models and were captured in the ecoregional models:

Permafrost.-Permafrost degradation was a process of concern in all ecoregions except the North Pacific Coast, where it occurs sporadically.

Phenology. - Changes in the timing and coordination of animal migrations relative to resource availability, freezethaw events, snow cover and river-stream discharge are predicted to result from climate change.

Marine-derived nutrients. - Nutrient inputs from marine sources are of variable importance. In all ecoregions except the Polar Ecoregion, marine-derived nutrients are carried by sizable salmon runs.
Fire.-This process is a major driver of the Interior Alaska Ecoregion whose frequency and severity are increasing, possibly in response to climate change. These increases will have important consequences for carbon dynamics. Recently, fire has also increased in frequency and extent in the Polar and Bering Coast Ecoregions.

Sea-ice dynamics.-The presence of sea ice and location of the ice edge are important for determining regional climate, stratification of the water column and nutrient distribution through the effect of ice on light reception and turbulence. Sea ice also controls coastal erosion and the amount of resulting sediment.

Human activities. - The nature and extent of human activities varied among ecoregions but were important everywhere. Recreational, commercial and subsistence harvests of fish and wildlife are important in all ecoregions. Oil and gas development continues to be a major factor in both marine and terrestrial ecoregions.

Long-distance migration of species. - These emigrations and immigrations have consequences for nutrient flows among ecoregions, dependence of animal status in one region on resource conditions in other areas, and connectivity of landscapes and habitats across broad spatial scales.

Freshwater flows. - These relate to melting of glaciers and, to a lesser extent, permafrost thawing. Rivers transport sediment, nutrients, and plant and animal propagules from upstream watersheds downstream, ultimately to marine ecosystems. They are important corridors for movement, in both summer and winter seasons.

Marine water stratification/upwelling.-The distribution of temperature, salinity and nutrients is important in all marine ecoregions, although the specific dynamics vary among ecoregions.

Marine/freshwater interaction. - The pattern of salinity in estuarine areas affects the distribution of eelgrass, phytoplankton, zooplankton, and other foundations of the food web. Anadromous fishes bring marine nutrients far inland, especially in more-southern latitudes. Runoff of freshwater from glaciers and rainfall (via surfacewater and overland flows) into marine ecosystems has consequences for chemistry of nearshore waters, bottom bathymetry, and coastal currents. 


\section{Future Steps in Ecoregional Monitoring Program Development}

The most fundamental need for an effective monitoring program is carefully considered objectives (Noon and others, 1999; Noon, 2003; Nichols and Williams, 2006; Lyons and others, 2008). In the adaptive-management framework for monitoring being adopted by USFWS, these objectives will take the form of 'fundamental management objectives' (e.g., self-sustaining populations of a given species) and 'means objectives' that will describe how the fundamental objective will be achieved (e.g., conserve or create habitat for the given species). The fundamental objectives will reflect the legislative and statutory mandates that apply to the Service and to individual refuges, including the Alaska National Interest Lands Conservation Act (ANILCA); the National Wildlife Refuge System Improvement Act; refuge-specific mission and vision statements; refuge-specific Comprehensive Conservations Plans (CCPs); refuge-specific Land Protection Plans (LPPs); refuge-specific Wildlife Inventory Plans (WIPs); and refuge-specific Fishery Management Plans. In addition to these, USFWS is currently pursuing the creation a framework of Landscape Conservation Cooperatives (LCCs) to address management challenges in the face of a changing climate. USFWS expects that "LCCs will be formal, science and management partnerships between the Service, U.S. Geological Survey, other federal agencies, states, tribes, NGOs, universities, and others to increase applied conservation science capacity in support of fish and wildlife management within specific landscapes."

The next step is to identify management actions that would be used to meet the management objectives if necessary. Historically, Alaska refuges have not been actively managed relative to other units in the refuge system due to their vast size and remote, relatively unaltered condition. In addition, the ANILCA mandate may be seen to restrict allowable management actions in Alaskan refuges compared with other NWRs. Nevertheless, management actions such as fire suppression or prescription and reduced harvest are actions that may be considered in the future to address biological consequences of climate change. These conceptual models can serve as the basis for a discussion of potential management actions and resource priorities, following reassessment of management philosophies, strategies, and actions to achieve refuge and DOI objectives through mitigation and adaptation in the face of climate change.

Finally, hypotheses about the consequences of potential management actions must be developed. The hypotheses can be developed and tested through the use of more-detailed conceptual models, deterministic and stochastic models,
Bayes nets, path-analysis diagrams, correlation diagrams or other more-rigorous approaches. Testing predictions of these models against outcomes forms the foundation of the adaptive management process.

Monitoring indicators will be identified at two points in this process. First, priority resources will be identified by developing management objectives based on legislative mandates and from refuge- and ecoregional-scale conceptual models. Specific monitoring indicators will be derived from detailed models describing the life histories or other relevant aspects of priority resources. Monitoring indicators also will be needed to test the veracity of the models describing competing hypotheses about the effects of management actions. These indicators will describe the outcome of management actions relative to management objectives.

If the USFWS desires to create subunits within the broad ecoregions we have defined, the Nowacki and others (2002) Level-1 classifications suggest one scheme by which to do this. Specifically, Intermontane Boreal could be split from the Alaska Range Transition and Coastal Mountains Transition Level-1 groupings, and thus unite the latter two groups in a 'Boreal Transition' subunit. Justifications for such a division are that discontinuous permafrost south of the Alaska Range is less frequent and ultimately ceases to exist within this zone, whereas it appears to be relatively uniformly frequent in the Intermontane Boreal area (Washburn 1973, but see Ferrians, 1965). Furthermore, fire-disturbance regimes are markedly different between the Intermontane Boreal and the Alaska Range Transition areas (K. Murphy, USFWS Fire Ecologist, oral commun., 2009). Similarly, if the USFWS desires to create subunits within the broad North Pacific Coast ecoregion we have defined, the Nowacki and others (2002) Level-1 classifications suggest one scheme by which to do this. In particular, the Aleutian Meadows (on the Alaska Peninsula and along the Aleutian chain) could be separated from the Coastal Rainforest level-1 group. Such a subdivision acknowledges the Bering Sea influence on the Aleutian chain, and may be one pragmatic solution for organizing in-person meetings within the ecoregion in a manner to minimize travel time and costs. We note, however, that there may be numerous axes by which to subdivide ecoregions, each of which may suggest different boundaries. If subunit classifications demand more infrastructure or personnel, they should be added judiciously.

A framework for developing monitoring for Alaska NWRs is the topic of a companion document (Woodward and Beever, 2010). This framework relies heavily on the conceptual models presented here to identify how ecological resources may respond to climate change, and then lays out a structure for developing a monitoring program at multiple spatial scales and degrees of collaboration to address those resources. 


\section{Acknowledgments}

This report is a product of a Science Support Partnership (SSP) project involving collaboration between the Alaska Regional office of the U.S. Fish and Wildlife Service (USFWS) and the U.S. Geological Survey. This report reflects the contributions of many individuals to the Conceptual Modeling Workshop during October 28-30, 2008, which was held during USFWS' annual Supervisory Biologists' meeting in Anchorage.

Staff members of the USFWS Alaska Regional Office, including Danielle Jerry (Chief of Realty and Natural Resources), Eric Taylor (Regional Refuge Biologist), and Joel Reynolds (Regional Biometrician) helped to plan and implement the meeting. Karen Murphy and Gene Long provided insights on incorporating fire-related processes into ecosystem models. Patrick Lieske provided substantial logistical assistance.

Staff of the U.S. Geological Survey Alaska Science Center (USGS-ASC), including Karen Oakley, Tony DeGange, Carl Markon, and Leslie Holland-Bartels provided valuable leadership support of the workshop. Numerous USGS-ASC administrative staff members were instrumental in facilitating various aspects of the modeling workshop. We are especially grateful to USGS-ASC staff members Layne Adams, David Douglas, Tom Fondell, Colleen Handel, Scott Hatch, Ben Jones, John Piatt, David Ward, and Chris Zimmerman for reviewing various ecoregional models.

Numerous individuals provided presentations during the workshop useful for constructing conceptual models that supplemented those of the workshop organizers. John Piatt (USGS-ASC) provided insights on the map of marine ecoregions. Michael Fleming (Raytheon Inc.) provided background on the analyses behind, and interpretation of, the most-recent map of the unified terrestrial ecoregions of Alaska (Nowacki and others, 2002). Sara Wesser provided lessons learned by the four Inventory and Monitoring networks of the U.S. National Park Service. Scott Rupp (University of Alaska, Fairbanks) reviewed research on the biotic and abiotic changes already observed and predicted to occur within Alaska as a result of contemporary climate change.

Facilitation of two workgroups at the workshop was provided by Karen Oakley (USGS-ASC) and Michael Shephard (Southwest Alaska Inventory and Monitoring Network, U.S. National Park Service).

Danielle Jerry (USFWS), Melinda Knutson (USFWS), Maggie MacCluskie (U.S. National Park Service, Central Alaska I\&M Network), John Martin (USFWS), Karen Murphy (USFWS), and Joel Reynolds (USFWS) provided critical reviews of the entire document. John Morton (USFWS), Vernon Byrd (USFWS), Layne Adams, David Douglas, Tom Fondell, Colleen Handel, Scott Hatch, Benjamin Jones, John Piatt, and David Ward, and Christian Zimmerman (all of USGS-ASC) peer-reviewed subsections of the document.
We also thank Benjamin Jones (USGS-ASC), Jacqueline Olson (USGS-EPN), William Gibbs (USGS-EPN) and Robert Crist (USGS-EPN) for help with the figures.

\section{References Cited}

Adams, L.G., S.D. Farley, C.A. Stricker, D J. Demma, G.H. Roffler, D.C. Miller, and R.O. Rye, 2010, Are inland wolfungulate systems influenced by marine subsidies of Pacific salmon? Ecological Applications 20:251-262.

Allen, J.L., S. Wesser, C.J. Markon, and K.C. Winterberger, 2006, Stand and landscape level effects of a major outbreak of spruce beetles on forest vegetation in the Copper River Basin, Alaska. Forest Ecology and Management 227:257266.

Alerstam, T., Bäckman, J., Gudmundsson, G.A., Hedenström, A., Henningsson, S.S., Karlsson, H., Rosén, M., and Strandberg, R., 2007, A polar system of intercontinental bird migration. Proceedings of the Royal Society B 274:25232530, doi:10.1098/rspb.2007.0633.

Anderson, P.J. and Piatt, J.F., 1999,Community reorganization in the Guld of Alaska following ocean climate regime shift. Marine Ecology Progress Series 189:117-123.

Bailey, R.G., 1980, Description of the ecoregions of the United States. U.S. Department of Agriculture Forest Service Mis. Publ. No. 1391. Washington, D.C.

Bailey, R.G. 1995, Description of the ecoregions of the United States ( ${ }^{\text {nd }}$ Edition): U.S. Department of Agriculture Forest Service Mis. Publ. No. 1391 (rev.), Washington, D.C.

Barber, M.C. 1994, Environmental monitoring and assessment program indicator development strategy: Environmental Protection Agency, Office of Research and Development, Environmental Research Laboratory, Report EPA/620/R-94/022, Athens, GA, USA.

Belant, J.L., Kielland, K., Follmann, E.H., and Adams, L.G., 2006, Interspecific resource partitioning in sympatric ursids: Ecological Applications 16:2333-2343.

Beltaos, S. and Burrell B.C., 2003, Climatic change and river ice breakup: Canadian Journal of Civil Engineering 30L145-155.

Berg, E.E., Henry, J.D., Fastie, C.L., De Volder, A.D., and Matsuoka, 2006, Spruce beetle outbreaks on the Kenai Peninsula, Alaska, and Kluane National Park and Reser S.M. ve, Yukon Territory- Relationship to summer temperatures and regional differences in disturbance regimes: Forest Ecology and Management 227:219-232. 
Black, R.F., 1954, Precipitation at Barrow, Alaska, greater than recorded: Eos. Transactions of the American Geophysical Union 35:206.

Boere, G., Galbraith, C. and Stroud, D.(eds), 2006, Waterbirds around the world: The Stainery Office, Edinburgh, U.K.

Bonan, G.B. and Shugart, H.H., 1989, Environmental factors and ecological processes in boreal forests: Annual Review of Ecology and Systematics 20:1-28.

Boutin, S., Krebs, C.H., Nams, V.O., Sinclair, A.R.E., Boonstra, R., O’Donoghue, M., and Doyle C. 2001, Experimental design and practical problems of implementation, in: Krebs, C.J., Boutin, S., and Boonstra, R., eds., Ecosystem dynamics of the boreal forest-The Kluane Project: Oxford University Press, New York, p. 49-66

Brabets, T.P., Frenzel, S. A., Markon, C., and DeGange A. R., 2006, Changing conditions in the Yukon River Basin, Alaska: Biological, geographical and hydrological research of the U.S. Geological Survey Alaska Science Center: Eos Trans. AGU, 87(52), Fall Meeting Supplement, Abstract B21C-1036.

Bradstreet, M.S.W., 1982, Occurrence, habitat use, and behavior of seabirds, marine mammals, and arctic cod at the Pond Inlet ice edge: Arctic 35:28-40.

Brodeur, R.D. and Ware, D.M. 1992, Long-term variability in zooplankton biomass in the subarctic Pacific Ocean: Fisheries Oceanography 1:32-38.

Brown, J., Ferrians, O.J., Jr., Heginbottom, J.A., and Melnikov, E.S., 1998, revised February 2001. Circum-arctic map of permafrost and ground ice conditions, Boulder, CO: National Snow and Ice Data Center/World Data Center for Glaciology, digital media.

Buckley, T.W., Greig, A., and Boldt J. L., 2009, Describing summer pelagic habitat over the continental shelf in the eastern Bering Sea, 1982-2006: NOAA Technical Memorandum NMFS-AFSC-196. U.S. Department of Commerce.

Cameron, R.D., Russell, D.E., Gerhart, K.L., White R.G., and Ver Hoef, J.M. 2000, Predicting parturition status of arctic caribou: Rangifer Special Issue 12:1-3.

Cameron, R.D., Smith, W.T., White R.G., and Griffith, B., 2002, The Central Arctic Caribou Herd, Douglas, D.C., Reynolds, P.E., and Rhode, E.B. (eds), in Arctic Refuge coastal plain wildlife research summaries: U.S. Geological Survey, Biological Research Division, Biological Sciences Report USGS/BRD/BSR-2002-0001, p. 38-45.

Carmack, E.C., and MacDonald, R.W., 2002, Oceanography of the Canadian Shelf of the Beaufort Sea: a setting for marine life: Arctic 55:29-45.
Chapin, F. S., and Starfield, A.M., 1997, Time lags and novel ecosystems in response to transient climatic change in arctic Alaska:Climate Change 35:449-461.

Chen, J.L., Tapley, B.D., and Wilson, C.R. 2006, Alaskan mountain glacial melting observed by satellite gravimetry: Earth and Planetary Science Letters 248:368-378.

Clement, J.L., Cooper L.W., and Grebmeier, J.M., 2004, Late winter water column and sea ice conditions in the northern Bering Sea: Journal Geophysical Research 109:C03022.

Coachman, L.K., 1986, Circulation, water masses, and fluxes on the southeastern Berin Sea shelf. Continental Shelf: Research 5:23-108.

Craig, P.C., 1989, An introduction to anadromous fishes in the Alaskan Arctic, in Norton, D. (ed), Biological Papers of the University of Alaska Research Advances on Anadromous Fish in Alrcitc Alaska and Canada: University of AlaskaFairbanks, Fairbanks Alaska, p 27-54.

Davis, R.A. and Thomson, D.H., 1984, Marine mammals. Proceedings of a conference on the Barrow Arch environment and possible consequences of planned offshore oil and gas development: LGL Ecological Research associates for the National Oceanic and Atmospheric Administration, Juneau, Alaska.

Davis, J.L., Valkenburg, P., and Reed D.J., 1980, Population dynamics of Alaska's Arctic Caribou Herd, in Reimers, E., Gaare E., and Skjenneberg S., eds: Proceedings Second International reindeer/caribou symposium, Dir. for Vilt. of Ferskvannsfisk, Trondeim, Norway. p. 595-604.

Demarchi, D.A., 1996, An introducti J.A. on to the ecoregions of British Columbia: Ministry of Environment, Lands and Parks, Victoria, British Columbia. Available at http:// srmwww.gov.bc.ca/ecology/ecoregions/.

Deppe, J.L., Wessels, K., and Smith, 2007, Alaska at the crossroads of migration: space-based ornithology: Alaska Park Science 6:53-58.

Doyle, M.J., Mier, K.L., Busby, M.S., and Brodeur, R.D., 2002. Regional variation in springtime ichthyoplankton assemblages in the northeast Pacific Ocean: Progress in Oceanography 53:247-281.

Dragoo, G.E., Byrd, G.V., and Irons, D.B., 2003, Breeding status, population trends and diets of seabirds in Alaska, 2001: U.S. Fish and Wildlife Service Report AMNWR 03/05.

Elsner, W.K., and Jorgenson, J.C., 2009, White spruce seedling (Picea glauca) discovered north of the Brooks Range along Alaska’s Dalton Highway: Arctic 62:342-344. 
Ely, C.R., Dau C.P, and Babcock, C.A., 1994, Decline in a population of spectacled eiders nesting on the YukonKuskokwim Delta, Alaska. Northwestern Naturalist 75:8187.

Environmental Monitoring and Assessment Program (EMAP), 1990, An overview of the Environmental Monitoring and Assessment Program, EMAP Monitor: EPA Office of Research and Development, Washington, D.C. EPA600/M-90/022.

Euskirchen, E.S., McGuire, A.D., Chapin III, F.S., Yi, S., and Thompson C.C., 2009, Changes in vegetation in northern Alaska under scenarios of climate change, 2003-2100Implications for climate feedbacks. Ecological Applications 19:1022-43.

Fabry, V.J., Seibel, B.A., Feely, R.A., and Orr, J.C., 2008, Impacts of ocean acidification on marine fauna and ecosystem processes. ICES Journal of Marine Science 65:414-432.

Fancy, S.G., Pank, L.F., Whitten, K.R., and Regelin, W.L., 1989, Seasonal movements of caribou in arctic Alaska as determined by satellite. Canadian Journal Zoology 67:644650 .

Farley, E.V., Jr., Murphy, J.M., Wind, B.W., Moss J.H., and Middleton, 2005, Distribution, migration pathways and size of western Alaska juvenile salmon along the eastern A. Bering Sea shelf: Alaska Fishery Research Bulletin 11:1526.

Ferrians, O.J., 1965, Permafrost map of Alaska: U.S. Geological Survey Miscellaneous Geologic Investigations Map I-445.

Flint, P.L., Mallek, M.J., King, R.J., Schmutz, J.A., Bollinger, K.S., and Derksen, D.B., 2008, Changes in the abundance and spatial distribution of geese molting near Teshekpuk Lake, Alaska: Interspecific competition or ecological change?: Polar Biology 31:549-556.

Ford, J., and Bedford, B.L., 1987, The hydrology of Alaska wetlands, USA: a review: Arctic and Alpine Research 19:209-229.

Frey, K.E., and McClelland, J.W., 2009, Impacts of permafrost degradation on arctic river biogeochemistry: Hydrological Processes 23(SI):169-182.

Gajewski, K., Viau, A., Atkinson, M., Sawanda D., and Wilson S., 2001, Sphagnum peatland distribution in northern America and Eurasia during the past 21,000 years: Global Biogeochemical Cycles 15:297-310.
Gearhead, S., Matumeak, W., Angutikjuaq, I., Maslanik, J., Huntington, H.P., Leavitt, J., Kagak, D.M., Tigullaraq, G., and Barry, R., 2006, "It's not that simple": A collaborative comparison of sea ice environments, their uses, observed changes, and adaptations in Barrow Alaska, USA and Clyde River, Nunavut, Canada: Ambio 35:203-211.

Gill, R.E., Jr., Butler, R.W., Tomkovich, P.S., Mundkur, T., and Handel, C.M., 1994, Conservation of North Pacific Shorebirds: Transactions of the North American Wildlife and Natural Resources Conference 59:63-78.

Gill, R.E., Jr., Tibbitts, T. L., Douglas, D C., Handel, C.M., Mulcahy, D.M., Gottschalck, J.C., Warnock, N., McCaffery, B. J., Battley P. F., and Piersma, T., 2009, Extreme endurance flights by landbirds crossing the Pacific Ocean: ecological corridor rather than barrier?: Proceedings Royal Society B 276:447-457.

Gold, L.W. and Lachenbruch, A.H., 1973, Thermal conditions in permafrost: a review of North American literature, Permafrost: Second International Conference, North American Contribution, National Academy of Sciences, Washington, D.C.

Gooseff, M.N., Blaser, A., Bowden W.B., and Jones J.B., 2009, Effects of hilslope thermokarst in northern Alaska: EOS, Transactions-American Geophysical Union 90, doi:10.1029/2009ED040001, 2009.

Grebmeier, J. M., Overland, J. E., Moore, S. E., Farley, E. V., Carmack, E. C., Cooper, L.W., Frey, K.E., Helle, J.H., McLaughlin, F A., and McNutt, S.L., 2006, A major shift in the northern Bering Sea. Science 311:1461-1464.

Gulf of Alaska Ecosystem Monitoring and Research Program (GEM), 2002, The GEM Program Document. Exxon Valdez Oil Spill Trustee Council, Anchorage, Alaska.

Heemskerk, M., Wilson K., and Pavao-Zuckerman. M., 2003, Conceptual models as tools for communication across disciplines: Conservation Ecology 7:8.

Heilman, P.E., and Gass, C.R., 1974, Parent materials and chemical properties of mineral soils in Southeast Alaska. Soil Science 117:21-27. F.S.

Hennon, P., and Shaw, C.G., III, 1997, The enigma of yellowcedar decline: What is killing these long-lived, defensive trees?: Journal of Forestry 95 (12):4-10.

Higuera, .P.E, Brubaker, L.B., Anderson, P.M., Brown, T.A., Kennedy, A.T. and Hu, 2008, Frequent fires in ancient shrub tundra: implications of paleorecords for arctic environmental change: PLoS ONE 3(3): e0001744. doi:10.1371/journal.pone.0001744. 
Hinkes, M.T., Lawrence, J.V.D., Kovach, S.D., Aderman, A.R., Woolington, J.D. and Seavoy, R.J., 2005, Influence of population growth on caribou herd identity, calving ground fidelity and behavior: Journal Wildlife Management 69:1147-1162.

Hock, R., Jansson, P., and Braun, L., 2005, in Huber, U.M., Reasoner, M.A. and Bugmann, H. (eds), Global change and mountain regions - a state of knowledge overview: Springer, Dordrecht, the Netherlands. p. 243-252

Huggett, R.J., 1993, Modeling the human impact on nature: systems analysis of environmental problems: Oxford University Press, NY, USA.

Intergovenmental Panel on Climate Change, 2007, Climate Change 2007: Synthesis Report. Intergovernmental Panel on Climate Change, Geneva, Switzerland. 184 pp.

Jaffe, D., McKendry, I. , Anderson T., and Price J., 2003, Six 'new' episodes of trans-Pacific transport of air pollutants: Atmospheric Envrionment 37: 391-404.

Jannett, F. J., Jr., Broschart, M.R., Grim, L.H., and Schaberl, J.P., 2007, Northerly range extensions of mammalian species in Minnesota: American Midland Naturalist 158:168-176.

Johnson, S.R., and Herter, D.R., 1989, The birds of the Beaufort Sea: British Petroleum Exploration (Alaska), Anchorage, Alaska. 372 p.

Johnstone, J., Hollingsworth, T.N., Chapin III, F.S., Mack, M., Schuur, and Verbyla, D., 2008, Final Report - JFSP Project 05-1-2-06, Managing Fire with Fire in Alaskan Black Spruce Forests: Impacts of Fire Severity on Successional Trajectory and Future Forest Flammability. Available from: http://www.fi rescience.gov/projects/05-1-2-06/05-1-2-06 final report.pdf.

Jones, B.M., Arp, C.D., Jorgenson, M.T., Hinkel, K.M., Schmutz, J.A., and Flint P.L., 2009, Increase in the rate and uniformity of coastline erosion in Arctic Alaska: Geophysical Research Letters 36. (L03503):362201362205, doi:10.1029/2008GL036205.

Jorgenson, M.T., Racine, C.H., Walters, J.C., and Osterkamp, T.E., 2001, Permafrost degradation and ecological changes associated with a warming climate in central Alaska: Climatic Change 48:551-579.

Jorgenson, T., and Ely, C., 2001, Topography and flooding of coastal ecosystems on the Yukon-Kuskokwim Delta, Alaska: implications for sea level rise. Journal of Coastal Research 17:124-136.
Jorgenson, J., Yoshikawa, T., Kanevskiy, K., Shur, M., Romanovsky, Y., Marchenko, V., Grosse, S., Brown, G., and Jones B., 2008, Permafrost characteristics of Alaska: Institute of Northern Engineering, University of Alaska, Fairbanks, AK. Map and text, 2 p.

Kasischke, E.S., Williams D., and Barry, D. 2002, Analysis of the patterns of large fires in the boreal forest region of Alaska: International Journal Wildland Fire 11: 131-144.

Kasischke, E.S., Hyer, E.J., Novellis, P.C., Bruhwiler, L.P., French, N.H.F., Sukhinin, A.I., Hewson, J.H., and Stocks. B.J., 2005, Influences of boreal fire emissions on northern hemisphere atmospheric carbon and carbon monoxide: Global Biogeochem. Cycles 19, GB1012, doi:10.1029/2004GB002300.

Keyser, A. R., Kimball, J. S., Nemani, R.R., and Running, S.W., 2000, Simulating the effects of climate change on the carbon balance of North American high-latitude forests: Global Change Biology 6:185-195.

Kidd, K.A., Schindler, D.W., Muir, D.C.G., Lockhart, W.L. and Hesslein, R.H., 1995, High concentrations of toxaphene in fishes from a subarctic lake. Science 269:240-242.

Kling, G.W., Kipphut, G.W., and Miller, M.C.,1991, Arctic lakes and streams as gas conduits to the atmosphere: implications for tundra carbon budgets: Science 251:298301.

Krueger, C.C., and Zimmerman C.E. ,eds., 2009, Pacific Salmon: Ecology and Management of Western Alaska's Populations. American Fisheries Society, Bethesda, MD.

Kushlan, J.A., Step, M.J., Parsons, K.C., Capp, J., Cruz, M.A., Coulter, M., Davidson, I., Dickson, L., Edelson, N., Elliot, R. and others. 2002, Waterbird conservation for the Americas: the North American waterbird conservation plan, v. 1.: Waterbird Conservation for the Americas. Washington, D.C.

Lachenbruch, A.H., Sass, J.H., Lawyer, L.A., Brewer, M.C., and others, 1987, Temperature and depth of permafrost on the Alaskan Arctic Slope, in: Alaska North Slope Geology: Alaska Geological Society. Book 50, vol. 2 p. 545-558, .

Laidler, G.J., Ford, J.D., Gough, W.A., Ikummaq, T., Gagnon, A.S., Kowal, S., Qrunnut, K. and Irngaut, C., 2009, Travelling and hunting in a changing Arctic: assessing Inuit vulnerability to sea ice change in Igloolik, Nunavut: Climate Change 94:363-397.

Lyons, J.E., Runge, M.C., Laskowski, H., and Kendall, W.L., 2008, Monitoring in the context of structured decision making and adaptive management: Journal of Wildlife Management 72:1683-1692. 
MacCarthy, G.R., 1952, Geothermal investigations on the Arctic Slope, Alaska: Transactions of the American Geophysical Union 33(4):589-593.

MacCluskie, M., and Oakley K., 2005, Central Alaska Network Vital Signs Monitoring Plan: U.S. Department of the Interior, National Park Service, Fairbanks, AK.

MacDonald, R.W., Barrie, L.A., Bidleman, T.F., Diamond, M.L, Gregor, D.J., Semkin, R.G., Strachan, W.M.J., Li, Y.F., Wania, F., Alaee, M., Alexeeva, L.B., Backus, S.M., Bailey, R., Bewers, J.M., Gobeil, C., Halsall, C.J., Harner, T., Hoff, J.T., Jantunen, L.M.M., Lockhart, W.L., Mackay, D., Muir, D.C.G., Pudykiewicsz, J., Reimer, K.J., Smith, J.N., Stern, G.A., Schroeder, W.H., Waemann, R., Yunker, M.B., 2000, Contaminants in the Cnandian Arcitc: 5 years of progress in understanding sources, occurrence and pathways. Science Total Environment 254:93-234.

Maddox, G.D., Poiani, K. E., and Unnasch R.E., 1999, Evaluating Management Success: using ecological models to ask the right monitoring question, in Johnson N., ed.: The Ecological Stewardship Project: A common reference for Ecosystem Management. Elsevier Science: Oxford.

Manley, P.N., Zielinski, W.J., Stuart, C.M., Keane, J.J., Lind, A J., Brown, C., Plymale, B.L., and Napper, C.O., 2000, Monitoring ecosystems in the Sierra Nevada: the conceptual model foundation. Environmental Monitoring and Assessment 64:139-152.

Martin, P.D., Jenkins, J.L., Adams, F.J., Jorgenson, M. T., Matz A.C., Payer, D.C., Reynolds, P.E., Tidwell, A.C., and Zelenak, J.R., 2009, Wildlife Response to Environmental Arctic Change: Predicting Future Habitats of Arctic Alaska. Report of the Wildlife Response to Environmental Arctic Change (WildREACH): Predicting Future Habitats of Arctic Alaska Workshop, 17-18 November 2008, Fairbanks, Alaksa: U.S. Fish and Wildlife Service.

Mason, O.K., Salmon D.K., and Ludwig S.L., 1996, The periodicity of storm surges in the Bering Sea from 1898 to 1993, based on newspaper accounts: Climatic Change 34:109-123.

McCabe, G.J., Clark, M.P., and Serreze, M.C., 2001, Trends in northern hemisphere surface cyclone frequency and intensity. Journal of Climate 14:2763-2768.

McMahon, G., Gregonis, S.M., Walton, S.W., Omernik, J.M., Thorson, T.D., Freeour, J.A., Rorick, A.H., and Keys, J.E., 2001, Developing a spatial framework of common ecological regions for the conterminous United States. Environmentla Management 28:293-316.

Meehl, G.A., and Washington, W.M., 1990, $\mathrm{CO}_{2}$ climate sensitivity and snow-sea-ice albedo parameterization in an atmospheric GCM coupled to a mixed-layer ocean model: Climatic Change 16:283-306.
Meier, M.F. and Dyurgerov, 2002, How Alaska affects the world. Science 297:350-351.

Miller, D.M., Finn, S.P., Woodward, Torregrosa, A., Miller, M.E., Bedford, D.R., and Brasher. A., 2010, Conceptual ecological models to guide integrated landscape monitoring of the Great Basin. USGS Scientific Investigations Report 2010-5133.

Miller, M., 2005, The structure and functioning of dryland ecosystems - conceptual models to inform long-term ecological monitoring: U.S. Geological Survey Scientific Investigations Report 2005-5197, 74 p.

Munkemuller, T., Reineking, B., Travis, J., Burgmann, H., and Johst, K., 2009, Disappearing refuges in time and space: How environmental change threatens species coexistence: Theoretical Ecology 2: 217-227.

Napp, J. M. and Hunt, G.L., 2001, Anomalous conditions in the south-eastern Bering Sea, 1997: linkages among climate, weather, ocean and biology: Fisheries Oceanography 10:61-68.

National Research Council, 1995, Review of EPA's environmental monitoring and assessment program: overall evaluation: National Research Council, National Academy Press, Washington, DC, USA.

National Research Council, 2003, Cumulative environmental impacts of oil and gas activities on Alaska's north slope: National Academy Press, Washington, D.C., U.S.A.

Neal, E.G., Hood, E., and Smikrud, K., 2010, Contribution of glacier runoff to freshwater discharge into the Guld of Alaska: Geophysical Research Letters 37: L06404.

Nichols, J. D., and Williams, B. K., 2006, Monitoring for conservation: Trends in Ecology and Evolution 21:668-673.

Noon, B.R., Spies, T.A., and Raphael, M.G., 1999, Conceptual basis for designing an effectiveness monitoring program. in: Mulder, B.S., Noon, B.R., Spies, T.A., Raphael, M.G., Palmer, C.J. , Olsen, A.R., Reeves, G.H., and Welsh, H.H., technical coordinators, The strategy and design of the effectiveness monitoring program for the Northwest Forest Plan, Portland, OR: U.S. Department of Agriculture Forest Service, Pacific Northwest Research Station: General Technical Report PNW-GTR-437, p. 49-68.

Noon, B.R., 2003, Conceptual issues in monitoring ecological resources, in Busch D.E., and Trexler, J.C eds., Monitoring ecosystems: interdisciplinary approaches for evaluating ecoregional initiatives: Island Press, Covelo, CA., p. 27-72.

Noss, R.F., 1990, Indicators for monitoring biodiversity: a hierarchical approach: Conservation Biology 4:355-364.

Nowacki, G., Spencer, P., Brock, T., Fleming, M., and Jorgenson, T., 2001, Ecogregions of Alaska and neighboring territories: U.S. Geological Survey, Reston, VA. 
Nowacki, G., Spencer, P., Fleming, M., Brock, T., and Jorgenson, 2002, Unified ecoregions of Alaska: 2001: U.S. Geological Survey Open File Report 02-297. 1 map. T.

Omernik, J.M., 2004, Perspectives on the nature and definition of ecological regions: Environmental Management 34:S27S38.

Orr, J.C., Fabry, V.J.; Aumont, O.; Bopp, L.; Doney, S.C.; Feely, R.A.; Gnanadesikan, A.; Gruber, N. A., Ishida, Joos, F, Key, R.M., Lindsay, E. Maier-Reimer, R. Matear, P. Monfray, A, Mouchet, R.G. Najjar, G. Plattner, K.B. Rodgers, C.L. Sabine, K., Sarmiento, J.L., Schlitzer, R., Slater, R.D., Totterdell, I.J., Weirig, M.; Yamanaka, Y.; and Yool, A., 2005, Anthropogenic ocean acidification over the twenty-first century and its impact on calcifying organisms: Nature 437:681-686.

Osterkamp, T.E., Viereck, L., Shur, Y., Jorgenson, M.T., Racine, C., Falcon, L., Doyle A., and Boone R.D., 2000, Observations of thermokarst and its impact on boreal forests in Alaska, U.S.A: Arctic, Antarctic and Alpine Research 32:303-315.

Overland, J.E., and Stabeno, P.J., 2004, Is the climate of the Bereing Sea warming and affecting the ecosystem? Eos 85:309-316.

Parmesan, C., 2006, Ecological and evolutionary responses to recent climate change: Annual Review of Ecology, Evolution, and Systematics 37: 637-669.

Person, B.T., Herzong, M.P., Ruess, R.W., Sedinger, J.S., Anthony R.M., and Babcock. C.A., 2003, Feedback dynamics of grazing lands: coupling vegetation change with animal growth: Oecologia 135: 583-592.

Péwé, T.L., 1975, Quaternary geology of Alaska: U.S. Geological Survey Professional Paper 836, 145 p.

Piatt, J.F., and Springer, A.M., 2003, Advection, pelagic food webs, and the biogeography of seabirds in Beringia: Marine Ornithology 31:141-154.

Piatt, J.F., and Springer, A.M., 2007, Marine ecoregions of Alaska, in Spies, R.B, Long-term ecological change in the northern Gulf of Alaska: Elsevier B.V., Oxford, UK. p. 522526.

Piatt, J.J.F., Wetzel, J., Bell, K., DeGange, A.R., Balogh, G.R., Drew, G.S., Geernaert, T., Ladd, C., and Byrd G.V., 2006, Predictable hotspots and foraging habitat of the endangered short-tailed albatross (Phoebastria albatrus) in the North Pacific: Implications for conservation: Deep Sea Research II 53:387-398.

Plafker, G., 1970, Tectonics of the March 27, 1964 Alaska earthquake: U.S. Geological Survey Professional Paper 543I. U.S. Government Printing Office, Washington, D.C. 74 p.
Post, A., and Mayo, L.R., 1971, Glacier dammed lakes and outburst floods in Alaska: U.S. Geological Survey Hydrologic Investigations Atlas HA-455, Washington, D.C.

Post, E., and Forchhamer, M.C., 2008, Climate change reduces reproductive success of an Arctic herbivore through trophic mismatch: Philosophical Transactions of the Royal Society of London, B (Biological Sciences) 363:2369-2375.

Post, E., Pedersen, C., Wilmers, C.C., and Forchhammer, M.C., 2008, Warming, plant phenology and the spatial dimension of trophic mismatch for large herbivores: Proceedings of the Royal Society B: Biological Sciences 275:2005-2013.

Prescott, W.H., and Lisowski, M., 1977, Deformation at Middleton Island, Alaska, during the decade after the Alaska earthquake of 1964: Bulletin of the Seismological Society of America 67:579-586.

Prospero, J.M., and Savoie, D. L., 1989, Effect of continental sources on nitrate concentrations over the Pacific Ocean: Nature 339:687-689.

Racine, C., Jandt, R.; Meyers, C., and Dennis, J., 2004, Tundra fire and vegetation change along a hillslope on the Seward Peninsula, Alaska, U.S.A: Arctic, Antarctic, and Alpine Research. 36:1-10.

Reynolds, K.M., and Hard, J.S., 1991, Risk and hazard of spruce beetle attack in unmanaged stands on the Kenai Peninsula, Alaska, under epidemic conditions: Forest Ecology and Management 43:137-151.

Richardson, W. J., 1995, Documented disturbance reactions, in Richardson, W.J., Greene, Jr., C R., Malme C. I., and Thomson, D.H., eds., Marine mammals and noise: Academic Press, San Diego, p. 241-324.

Riordan, B., Verbyla, D., and McGuire, A.D., 2006, Shrinking ponds in subarctic Alaska based on 1950-2002 remotely sensed images: Journal of Geophysical Research, vol. 111, G04002, doi:10.1029/2005JG000150.

Rupp, T.S., Chapin III, F.S., and Starfield, A.M., 2001, Modeling the influence of topographic barriers on treeline advance at the forest-tundra ecotone in northwestern Alaska: Climate Change 48:399-416.

Rupp, T.S., Starfield, A.M., Chapin III, F.S., and Duffy, P., 2002, Modeling the impact of black spruce on the fire regime of Alaskan boreal forest: Climatic Change 55:213233.

Salanthé, E.P., Jr., 2006, Influences of a shift in North Pacific storm tracks on western North American precipitation under global warming: Geophysical Research Letters 33:1-4. 
Sanford, E., 2002, Community responses to climate change: links between temperature and keystone predation in a rocky intertidal system, in Schneider S.H., and Root, T.L., eds., Wildlife responses to climate change: North American case studies. Island Press, Covelo, CA., p. 165-200.

Schaefer, J.R., and Nye, C., 2008, The Alaska Volcano Observatory - 20 years of volcano research, monitoring, and eruption response: Alaska Division of Geological \& Geophysical Surveys, Alaska GeoSurvey News, NL 2008001, 11:1-9, available at http://wwwdggs.dnr.state.ak.us/ pubs/pubs?reqtype $=$ citation $\& I D=16061$.

Schumacher, J.D., Kruse, G.H., and Macklin, S.A., eds., 2005, The Aleutian ecosystem: processes controlling variability in productivity and ecosystem structure: Fisheries Oceanography 14:1-306.

Serreze, M.C., Maslanik J.A., and Key, J.R., 1997, Atmospheric and sea-ice characteristics of the Arctic Ocean in the SHEBA field region I north Beaufort Sea: National Snow and Ice Data Center, CIRES, University of Colorado, Boulder, Colorado.

Sherman, K., Alexander, L.M., and B.D. Gold, eds., 1990, Large marine eocsystems:patterns, processes, and yields. American Association for the Advancement of Science, Washington, D.C, $242 \mathrm{p}$.

Shulski, M. and Wendler, G., 2007, The Climate of Alaska. University of Alaska Press, Fairbanks, 216 p.

Shur, Y.L., and Jorgenson, M.T., 2007, Patterns of permafrost formation and degradation in relation to climate and ecosystems: Permafrost and Periglacial Processes 18:7-19.

Sinclair, E.H. and Stabeno, P.J., 2002, Mesopelagic nekton and associated physics of the southeastern Bering Sea: Deep Sea Research II 49:6127-6145.

Springer, A.M., and McRoy, C.P., 1993, The paradox of pelagic fod webs in the northern Bering Sea: III, Patterns of primary production: Continental Shelf Research 13:575599.

Springer, A.M., McRoy, C.P., and Flint, M.V., 1996, The Bering Sea Green Belt: Shelf-edge processes and ecosystem production.: Fisheries and Oceanography 5:205-223.

Springer, A.M., Piatt, J.F., Shuntov, V.P., van Vliet, G.B., Vladimirov, V.L., Kuzin, A.E. and. Perlov, A.S., 1999, Marine birds and mammals of the Pacific Subarctic Gyres: Progress in Oceanography 43:443-487.
Stabeno, P. J., Schumacher, J. D., and Ohtani, K., 1999, The physical oceanography of the Bering Sea: a summary of physical, chemical, and biological characteristics, and a synopsis of research on the Bering Sea, in Loughlin, T.R., and Ohtani K., eds., Dynamics of the Bering Sea: University of Alaska Sea Grant AK-SG-99-03, Fairbanks, Alaska, p. 631-650.

Stabeno, P. J., Bond, N.A.; Kachel, N.B., Salo, S A., and Schumacher. J.D., 2008, On the temporal variability of the physical environment over the south-eastern Bering Sea: Fisheries Oceanography 10:81-98.

Stabeno, P. J., Bond, N. A.; Kachel, N. B., Salo, S. A.; Schumacher. J.D., 2001, On the temporal variability of the physical environment over the southeastern Bering Sea: Fisheries Oceanography 10:81-98.

Stenseth, N.C., and Mysterud, A., 2002, Climate, changing phenology, and other life history traits: Nonlinearity and match-mismatch to the environment: Proceedings of the National Academy of Sciences 99:13379-13381.

Stroeve, J., Holland, M.M., Meier, W., Scambos, T., Serreze, M., 2007, Arctic seas ice decline: faster than forecast: Geophysical Research Letters 34: L09501.

Sturm, M., Racine, C., and Tape, K., 2001, Increasing shrub abundance in the Arctic:Nature 411:546-547.

Tans, P., 2009, An accounting of the observed increase in oceanic and atmospheric $\mathrm{CO}_{2}$ and an outlook for the future; Oceanography 22:26-35.

Tape, K., Sturm, M., and Racine. C., 2006, The evidence of shrub expansion in Northern Alaska and the pan-Arctic. Global Change Biology 12:686-702.

Thornton, K. W., Saul, G. E., and Hyatt, D.E., 1994, Environmental Monitoring and Assessment Program assessment framework, EPA/620/R-94/016: U.S. Environmental Protection Agency Office of Research and Development, Research Triangle Park, NC.

Toniolo, H., Kodial, O.; Hinzman, L.D.; and Yoshikawa, K., 2008, Spatio-temporal evolution of a thermokarst in interior Alaska: Cold Regions Science and Technology 56:39-49.

Tynan, C.T., and DeMaster. D.P., 1997, Observations and predictions of Arctic climatic change: Potential effects on marine mammals: Arctic 50:308-322.

Verbyla, D., 2008, The greening and browning of Alaska based on 1982-2003 satellite data: Global Ecology and Biogeography, 17:547-555. 
Verbyla, D. and Lord, R., 2008, Estimating post-fire organic soil depth in the Alaskan boreal forest using the Normalized Burn Ratio: International Journal of Remote Sensing 29:3845-3853.

Visser, M.E. and Both, C., 2005, Shifts in phenology due to climate change: the need for a yardstick, Proceeding of the Royal Society B: Biological Sciences 268:289-294.

Visser, M.E., van Noordwijk, A.J., Tinbergenand, J.M., Lessells, C.M., 1998, Warmer springs lead to mistimed reproduction in great tits (Parus major: Proceedings Royal Society B 265:1867-1870.

Vitt, D.H., Halsey, L.A., and Zoltai, S.C., 2000, The changing landscape of Canada's western boreal forest: the current dynamics of permafrost. Canadian Journal of Forest Research 30:283-287.

Walker, G., 2007, Climate change 2007: A world melting from the top down: Nature 446:718-721.

Walsh, J. J., McRoy, C.P.; Coachman, L.K., Georing, J.J., Nihoul, J.J., Whitledge, T.E., Blackburn, P.L. Parker, T.H., Wirick, C.D., Shuert, P.G., Grebmeier, J.M., Springer, A.M., Tripp, R.D., Hansell, D.A., Djenidi, S., Deleersnijder, E., Henricksen, K., Lund, B.A., Andersen, P., Muller-Karger, F.E., and. Dean K, 1989, Carbon and nitrogen cycling with the Bering/Chukchi Seas: Source regions for organic matter affecting AOU demands of the Arctic ocean: Progress in Oceanography 22:277-259.

Walsh, J.E., Chapman W.L., and Shy, T.L., 1996, Recent decrease of sea-level pressure in the central Arctic: Journal of Climate 9:480-486.
Walter, K.M., Zimov, S.A., Chanton, J.P., Verbyla, D., and Chapin III F.S., 2006, Methane bubbling from Siberian thaw lakes as a positive feedback to climate warming: Nature 443:71-75.

Washburn, A.L., 1973, Periglacial processes and environments. Edward Arnold, London.

Williams, B.K., Szaro, R.C., and Shapiro, C.D., 2007, Adaptive management: The U.S. Department of the Interior technical guide: Adaptive Management Working Group, U.S. Department of the Interior, Washington, D.C. 72 p. (http://www.doi.gov/initiatives/AdaptiveManagement/ documents.html)

Wise, J.L., Comiskey A.L., and Becker, R., 1981, Storm surge climatology and forecasting in Alaska: Arctic Environmental Information and Data Center, University of Alaska, Anchorage.

Woodward, A. and Beever, E.A., 2010, Framework for ecological monitoring on lands Alaska national wildlife refuges and their partners: U.S. Geological Survey Open File Report 2010-1300.

Yoshikawa, K., Hinzman, L.D., and Kane, D.L., 2007, Spring and aufeis (icing) hydrology in Brooks Rnage, Alaska: Journal of Geophysical Research 112:G04S43.

Yoshikawa, K. and Hinzman, L.D., 2003, Shrinking thermokarst ponds and groundwater dynamics in discontinuous permafrost near Council, Alaska: Permafrost and Periglacial Processes 14:151-160.

Zimov, S.A., Voropaev, Y.V., Semiletov, I.P., Davidov, S.P., Prosiannikov, S.F., Chapin, F.S., Chapin, M.C., Trumbore, S., and Tyler, S., 1997, North Siberian lakes: A methane source fuelled by Pleistocene carbon: Science 277:800-802. 
This page left intentionally blank 


\section{Appendix 1. Comparisons between Ecoregional Classifications and Landscape Conservation Cooperatives}

The USFWS and the Department of Interior recently adopted a collaborative partnership approach to conservation issues called Landscape Conservation Cooperatives (LCCs, http://www.fws.gov/science/shc/lcc.html). The LCCs are a network of partnerships among Federal and State agencies and non-government organizations (NGOs) operating within a specific landscape and facilitated by the USFWS. To create the geographic areas associated with each LCC, USFWS divided the country into ecoregions based on Bird Conservation Regions (BCRs; United States North American Bird Conservation Initiative, 2000), which were originally based on Omernik’s (1987) land classifications. The main distinction between LCCs and the scheme used in this report is the inclusion of the Alaska Peninsula and Kodiak Island with the Bering coastal area in the LCC map. In this case, the LCC map does not agree with the original Omernik classification and likely reflects the emphasis of BCRs on the distribution of avian species. The flexibility of the LCC map for addressing concerns about taxa other than birds and for collaboration with other agencies needs further review. Whereas LCCs are being adopted by the USFWS in the lower 48 states and Hawaii, the boundaries are still under discussion in Alaska with the LCC partners (Danielle Jerry, U.S. Fish and Wildlife Service, personal commun.). Should the original LCCs be adopted as the framework for management and monitoring in Alaska, there is a simple relationship between LCCs and the ecoregions used here (table A1.1, fig. A1.1). In general, refuges classified as Polar in this report would be classified as Arctic using the LCCs; refuges in Interior Alaska would be classified as Northwestern Interior Forest; refuges in Bering Coast and North Pacific Coast would be classified as Western Alaska. Exceptions are the part of Selawik NWR that is classified as Bering Coast, and the part of Kenai NWR that is classified as North Pacific Coast in this report. Alaska Maritime NWR has units throughout either classification.

\section{References}

Omernik, J.M., 1987, Map supplement: ecoregions of the conterminous United States: Annals of the Association of American Geographers, 77(1):118-125.

United States North American Bird Conservation Initiative, 2000, Bird Conservation Region Descriptions: A Supplement to the North American Bird Conservation Initiative Bird Conservation Regions Map, U.S. Fish and Wildlife Service, Division of Bird Habitat Conservation, Arlington, VA. 
Table A1.1. Comparison of refuge classifications by ecoregions adopted for this report, compared with classifications by Landscape Conservation Cooperatives (LCCs; $h$ ttp://www.fws.gov/science/shc/lcc.html).

[Note that several refuges have areas in more than one ecoregion]

\begin{tabular}{|c|c|c|}
\hline Refuge & Ecoregion & LCC \\
\hline $\begin{array}{l}\text { Arctic } \\
\text { Alaska Maritime }\end{array}$ & Polar & Arctic \\
\hline $\begin{array}{l}\text { Arctic } \\
\text { Innoko } \\
\text { Kanuti } \\
\text { Kenai } \\
\text { Koyukuk } \\
\text { Nowitna } \\
\text { Selawik } \\
\text { Tetlin } \\
\text { Yukon Flats }\end{array}$ & Interior Alaska & $\begin{array}{l}\text { Northwestern Interior } \\
\text { Forest }\end{array}$ \\
\hline Selawik & & $\begin{array}{l}\text { Northwestern Interior } \\
\text { Forest, Western Alaska }\end{array}$ \\
\hline $\begin{array}{l}\text { Togiak } \\
\text { Yukon Delta } \\
\text { Alaska Maritime }\end{array}$ & Bering Coast & Western Alaska \\
\hline $\begin{array}{l}\text { Alaska Maritime } \\
\text { Alaska Peninsula } \\
\text { Becharof } \\
\text { Izembek } \\
\text { Kodiak }\end{array}$ & North Pacific Coast & Western Alaska \\
\hline Kenai & & Northern Pacific \\
\hline
\end{tabular}




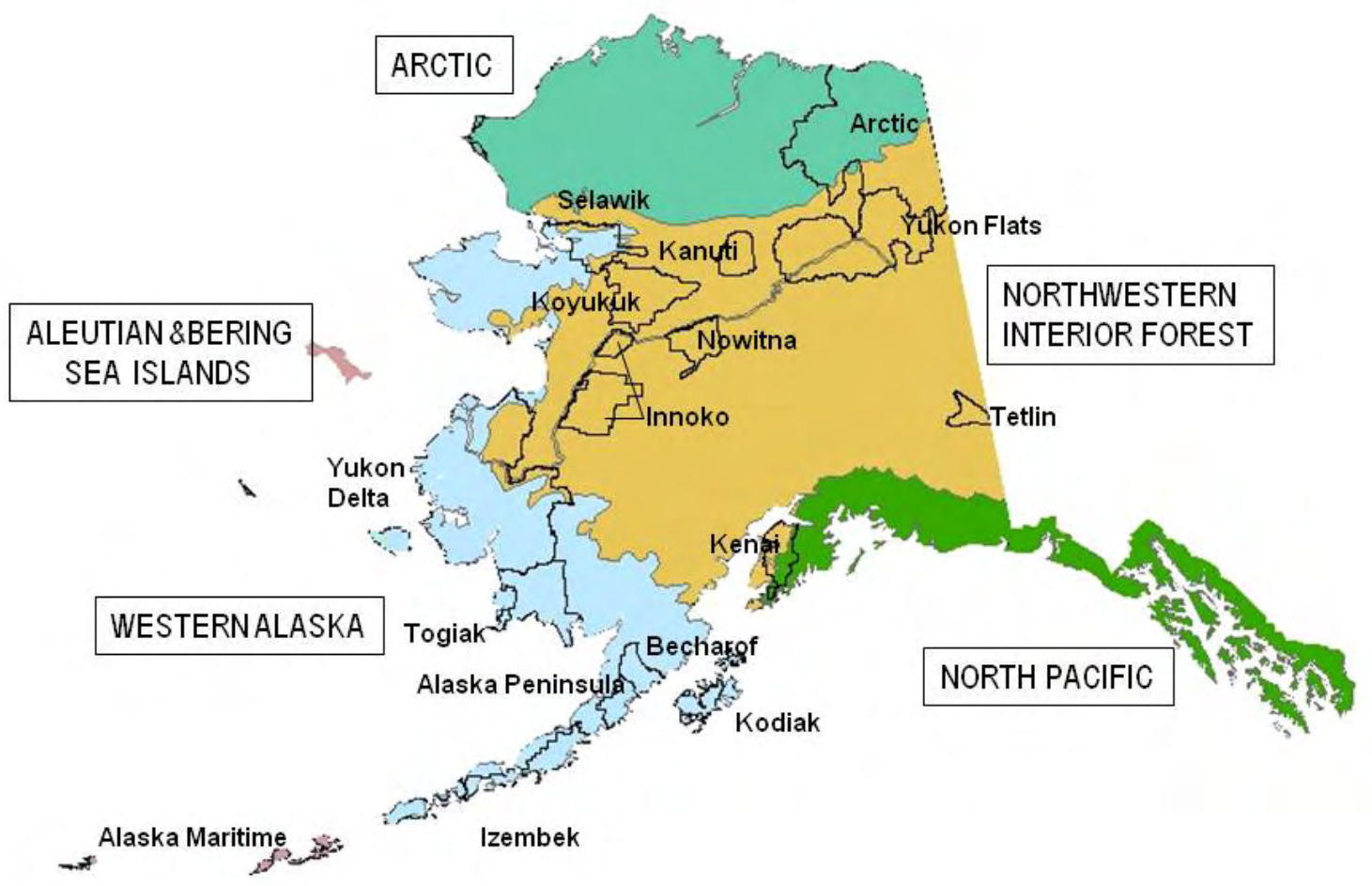

Figure A1.1. Boundaries of National Wildlife Refuges within Alaska, in relation to the Landscape Conservation Cooperatives (http://www.fws. gov/science/shc/llc.html). 
Table A1.2. Proportional representation of ecoregions in the state of Alaska and in Alaska National Wildlife Refuges.

\begin{tabular}{|c|c|c|c|c|c|c|c|c|c|c|c|}
\hline Ecoregion Name & Level-1 classifications & Revised Ecoregion Type & $\begin{array}{c}\text { Corresponding BCR 'community } \\
\text { type' }\end{array}$ & 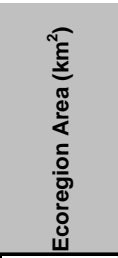 & 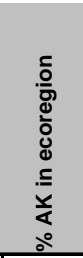 & 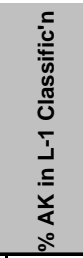 & 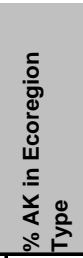 & 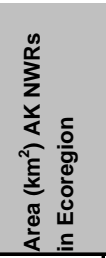 & 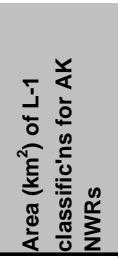 & 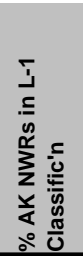 & 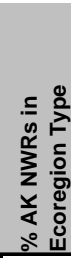 \\
\hline Beaufort Coastal Plain & Arctic Tundra & Polar & Arctic Plains \& Mtns. & 64194 & 3.8 & & & 4198 & & & \\
\hline Brooks Foothills & Arctic Tundra & Polar & Arctic Plains \& Mtns. & 115232 & 6.8 & & & 7284 & & & \\
\hline Brooks Range & Arctic Tundra & Polar & Arctic Plains \& Mtns. & 156172 & 9.2 & 19.8 & 19.8 & 41219 & 52701 & 14.7 & 14.7 \\
\hline Kotzebue Sound Lowlands & Bering Tundra & Coastal Boreal & W. AK ; NW Interior Forest & 14014 & 0.8 & & & 5749 & & & \\
\hline Seward Peninsula & Bering Tundra & Coastal Boreal & Western Alaska & 47346 & 2.8 & & & 227 & & & \\
\hline Bering Sea Islands & Bering Tundra & Coastal Boreal & Aleutian/Bering Sea Is.; NWern Int & 9526 & 0.6 & 4.2 & & 4538 & 10513 & 2.9 & \\
\hline Nulato Hills & Bering Taiga & Coastal Boreal & Northwestern Interior Forest & 58410 & 3.4 & & & 1787 & & & \\
\hline Yukon-Kuskokwim Delta & Bering Taiga & Coastal Boreal & Western Alaska & 76749 & 4.5 & & & 74743 & & & \\
\hline Ahklun Mountains & Bering Taiga & Coastal Boreal & Western Alaska & 38712 & 2.3 & & & 21174 & & & \\
\hline Bristol Bay Lowlands & Bering Taiga & Coastal Boreal & Western Alaska & 31986 & 1.9 & 12.1 & 16.3 & 4992 & 102697 & 28.6 & 31.5 \\
\hline Kuskokwim Mountains & Intermontane Boreal & Intermontane Boreal & Northwestern Interior Forest & 85359 & 5.0 & & & 5183 & & & \\
\hline Yukon River Lowlands & Intermontane Boreal & Intermontane Boreal & Northwestern Interior Forest & 51730 & 3.1 & & & 36382 & & & \\
\hline Kobuk Ridges and Valleys & Intermontane Boreal & Intermontane Boreal & Northwestern Interior Forest & 55135 & 3.3 & & & 13702 & & & \\
\hline Ray Mountains & Intermontane Boreal & Intermontane Boreal & Northwestern Interior Forest & 51243 & 3.0 & & & 8853 & & & \\
\hline Tanana-Kuskokwim Lowland & Intermontane Boreal & Intermontane Boreal & Northwestern Interior Forest & 64015 & 3.8 & & & 2732 & & & \\
\hline Yukon-Tanana Uplands & Intermontane Boreal & Intermontane Boreal & Northwestern Interior Forest & 102496 & 6.0 & & & 997 & & & \\
\hline Yukon-Old Crow Basin & Intermontane Boreal & Intermontane Boreal & Northwestern Interior Forest & 72736 & 4.3 & & & 43717 & & & \\
\hline Davidson Mountains & Intermontane Boreal & Intermontane Boreal & Northwestern Interior Forest & 33734 & 2.0 & & & 21487 & & & \\
\hline North Ogilvie Mountains & Intermontane Boreal & Intermontane Boreal & Northwestern Interior Forest & 52163 & 3.1 & 33.6 & & 1255 & 134309 & 37.4 & \\
\hline Lime Hills & Alaska Range Transitid & dIntermontane Boreal & Northwestern Interior Forest & 28715 & 1.7 & & & 0 & & & \\
\hline Cook Inlet Basin & Alaska Range Transitid & dIntermontane Boreal & Northwestern Interior Forest & 29082 & 1.7 & & & 4806 & & & \\
\hline Alaska Range & Alaska Range Transitid & IIntermontane Boreal & Northwestern Interior Forest & 103334 & 6.1 & & & 416 & & & \\
\hline Copper River Basin & Alaska Range Transitid & Intermontane Boreal & Northwestern Interior Forest & 19138 & 1.1 & 10.6 & 44.2 & 0 & 5222 & 1.5 & 38.8 \\
\hline Wrangell Mountains & Coastal Mtns. Transitid & dMaritime & Northwestern Interior Forest & 14314 & 0.8 & & & 0 & & & \\
\hline Kluane Range & Coastal Mtns. Transitid & garitime & Northwestern Interior Forest & 20924 & 1.2 & 2.1 & & 10 & 10 & 0.0 & \\
\hline Aleutian Islands & Aleutian Meadows & Maritime & Western Alaska & 13365 & 0.8 & & & 11624 & & & \\
\hline Alaska Peninsula & Aleutian Meadows & Maritime & Western Alaska & 63720 & 3.8 & 4.5 & & 28505 & 40130 & 11.2 & \\
\hline Kodiak Island & Coastal Rainforests & Maritime & Western Alaska & 12727 & 0.8 & & & 10274 & & & \\
\hline Gulf of Alaska Coast & Coastal Rainforests & Maritime & Northern Pacific Rainforest & 17588 & 1.0 & & & 153 & & & \\
\hline Chugach-St. Elias Mountains & Coastal Rainforests & Maritime & Northern Pacific Rainforest & 93133 & 5.5 & & & 3218 & & & \\
\hline Boundary Ranges (Northern Co & Coastal Rainforests & Maritime & Northern Pacific Rainforest & 42282 & 2.5 & & & 0 & & & \\
\hline Alexander Archipelago & Coastal Rainforests & Maritime & Northern Pacific Rainforest & 55247 & 3.3 & 13.0 & 19.7 & 10 & 13655 & 3.8 & 15.0 \\
\hline TOTAL & & & & 1694524 & 100.0 & 100.0 & 100.0 & 359237 & 359237 & 100.0 & 100.0 \\
\hline
\end{tabular}


No constraints were put on the form, terminology, or use of symbols across refuge models presented in appendixes $2-14$, so as not to limit creativity. Refuge staff members were asked to label arrows in their models, to the extent practicable, and to expound on relationships in the model narrative, thereby providing insight into the thought processes behind the heuristic information communicated. Narratives are as provided with the exception of minor edits and the addition of scientific names for species. 
This page left intentionally blank 


\section{Appendix 2. POLAR ECOREGION - Arctic National Wildlife Refuge}

By David Payer, Supervisory Biologist, Arctic NWR

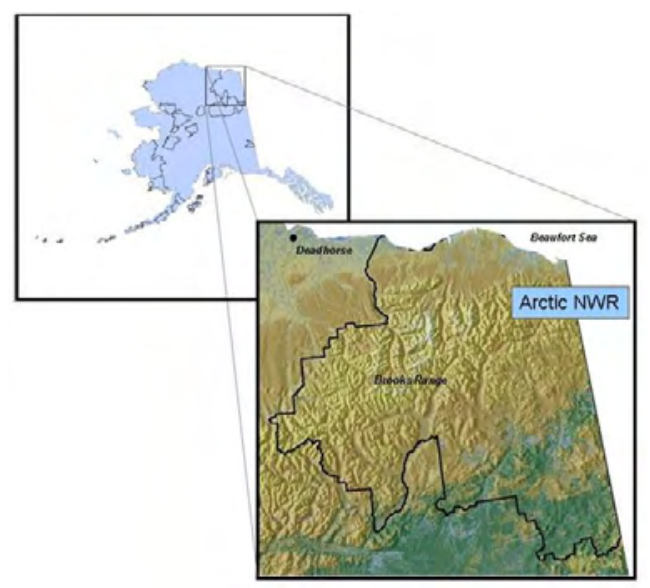

\section{Geographic Context}

The Arctic NWR occupies the northeastern corner of Alaska and is entirely north of the Arctic Circle. This 7,804,813-ha conservation area is the largest National Wildlife Refuge in the United States. It includes the largest designated Wilderness area within the National Wildlife Refuge System, the 2,894,212-ha Mollie Bettie Wilderness Area. Arctic NWR includes diverse landforms and habitats, from the boreal forest to the Beaufort Sea. The refuge is dominated by the mountains and foothills of the Brooks Range, and includes the highest peaks of that range (fig. A2.1).

The polar portion extends northward from the Brooks Range and across the coastal plain, to the coast, coastal lagoons, and barrier islands of the Beaufort Sea. This portion of the Arctic NWR is dominated by a variety of tundra types, including wet, moist, tussock, and shrub tundra and is dissected by numerous north-flowing braided rivers and streams. North of the Brooks Range, the majority of the landscape is upland with gently rolling to flat topography. Thaw-lake plain and riparian areas are far more limited in spatial extent, but are biologically significant for many species. Elevations within the polar portion of Arctic NWR range from sea level to 2,761 m at the summit of Mt. Isto. 


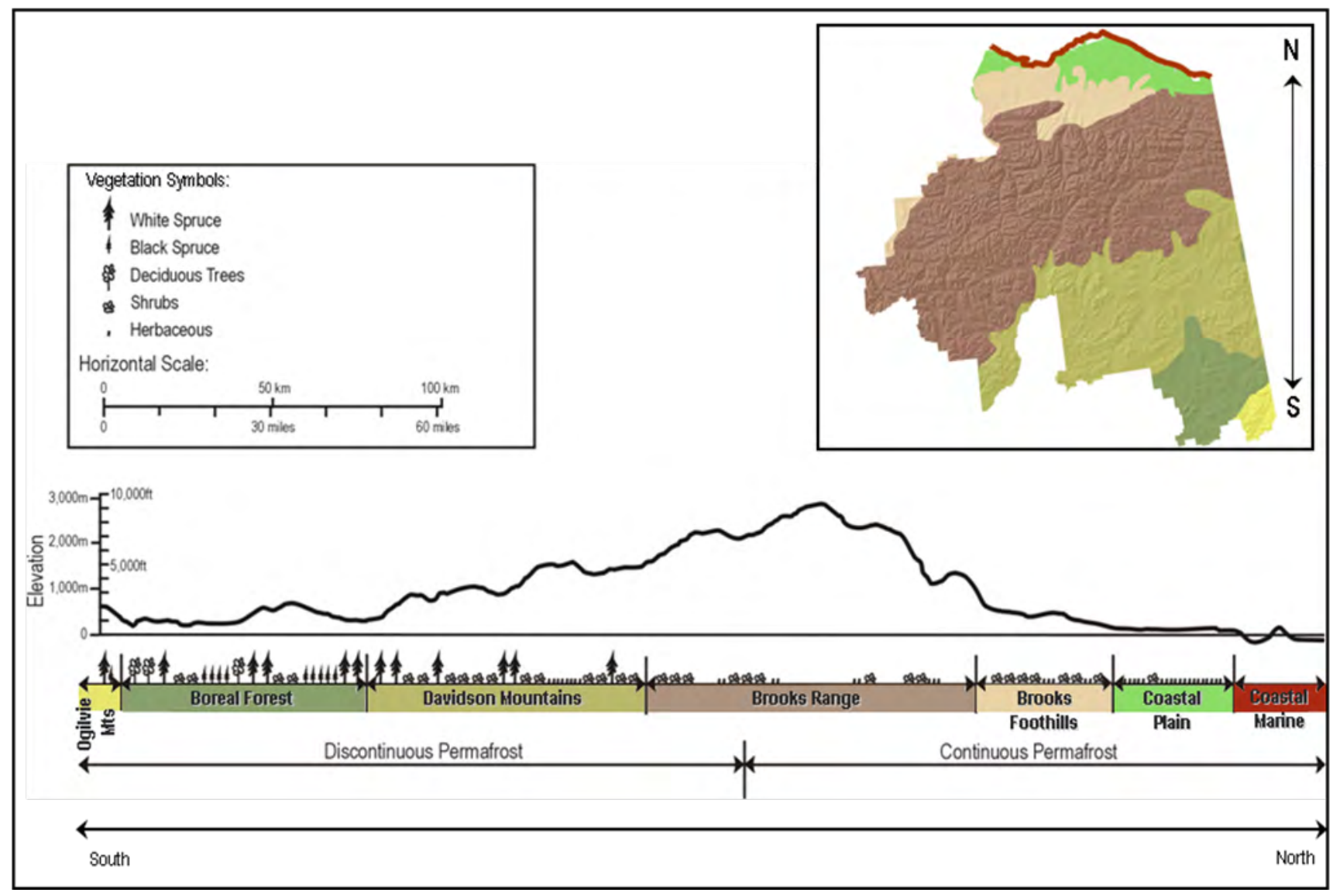

Figure A2.1. Ecological regions of the Arctic National Wildlife Refuge, based on Nowacki and others (2001). Map of refuge (top) and idealized cross-sectional profile (bottom). Vegetation symbols represent dominant vegetation types characteristic of each region.

\section{Climate}

Temperature, cloudiness, precipitation, and radiation vary widely from season to season at this high latitude $\left(66.6^{\circ} \mathrm{N}\right.$ to above $\left.70^{\circ} \mathrm{N}\right)$, but overall, climatic conditions are harsh, with freezing temperatures and snowfall possible at any time. Winter conditions exist for 8-9 months of the year and the sun remains below the horizon from late November through mid-January (fig. A2.2). During this period, freezing temperatures and high winds prevail (Shulski and Wendler, 2007). During summer, the coast is typified by strong winds, cool temperatures, and fog, while inland areas often have warmer temperatures, variable wind, and clearer skies. Precipitation on the coastal plain occurs frequently as drizzle in summer and light rain in winter (Douglas and others, 2002). At Prudhoe Bay, approximately $90 \mathrm{~km}$ west of the refuge, below freezing temperatures are recorded on $287 \mathrm{~d} / \mathrm{yr}$, and the average annual temperature is $-12^{\circ} \mathrm{C}$ (Shulski and Wendler, 2007). Mean high temperature in July is $12^{\circ} \mathrm{C}$, and mean low temperature in February is $-32^{\circ} \mathrm{C}$. Prudhoe Bay receives an average of $10.2 \mathrm{~cm}$ of precipitation annually, and average annual snowfall is $88 \mathrm{~cm}$. Prevailing wind direction is eastward, and wind speed averages $5 \mathrm{~m} / \mathrm{s}$ (Shulski and Wendler, 2007). 


\section{Environmental conditions in arctic Alaska}

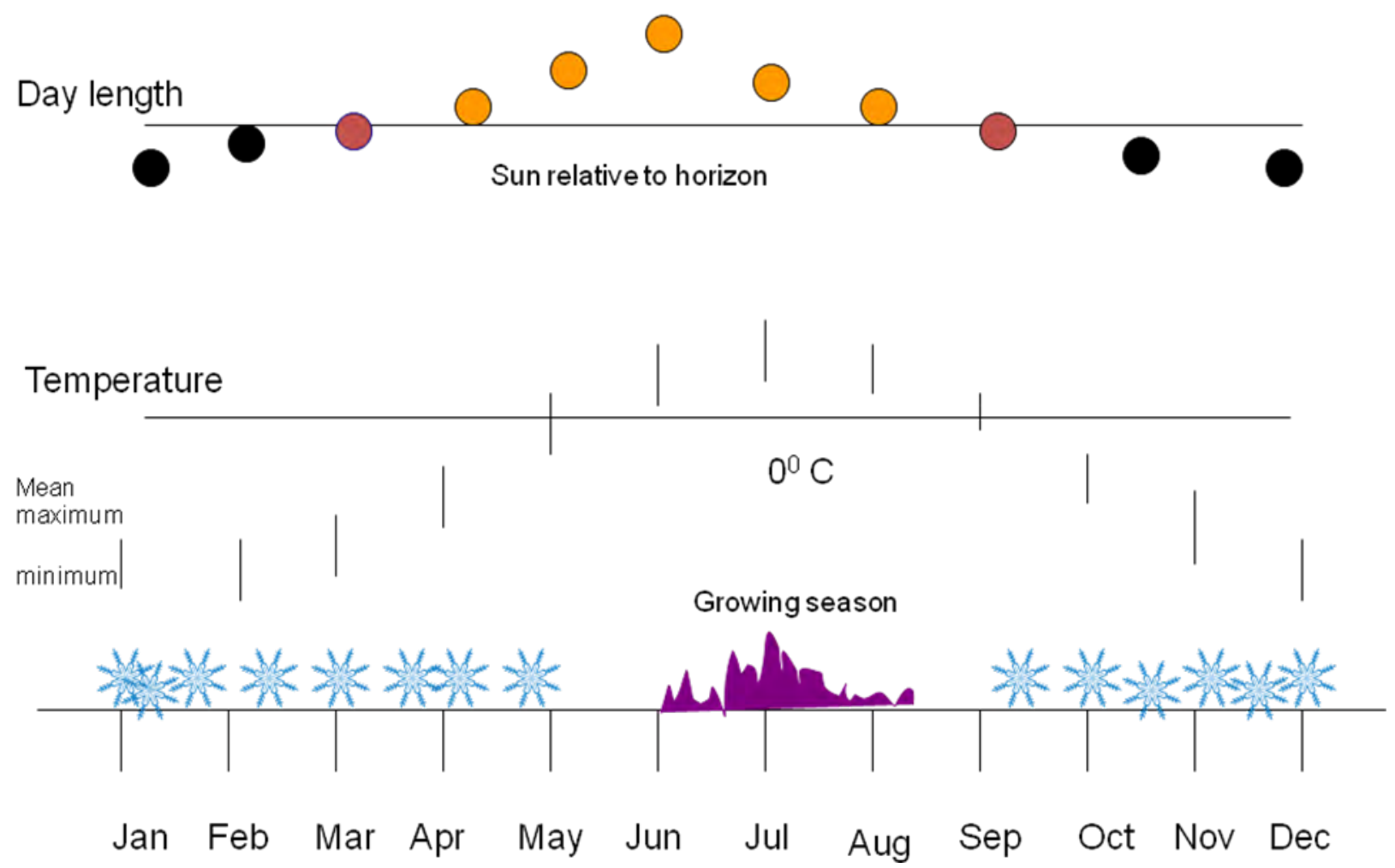

Figure A2.2. Annual cycle of insolation, temperature, and primary production on the Arctic Coastal Plain of Alaska.

\section{Abiotic Components}

Permafrost, the hydrologic system, geologic features, and climate are the most important abiotic components of the polar portion of the Arctic NWR. The extremely cold arctic temperatures maintain continuous permafrost that formed during past ice ages. Permafrost, bedrock geology, soil properties and runoff of glacial meltwater drive the hydrologic system. Arctic sea ice and marine waters affect the climate of the refuge. Winds are a prominent feature of the Arctic landscape, affecting snow redistribution patterns and water and energy balance of aboveground organisms.

\section{Biotic Components}

The Arctic NWR includes a diversity of boreal, montane, and arctic-tundra vegetation types, which host a commensurate diversity of wildlife species. Nearly 200 species of birds have been documented here. Migratory species include a variety of waterfowl, shorebirds, raptors, and passerines. Resident species include ptarmigan (Lagopus lagopus), ravens (Corvus spp.), gyrfalcons (Falco rusticolus) and American dippers (Cinclus mexicanus). Thirty-six species of fish and forty-five migratory or resident mammal species use the refuge, including nine marine mammals. Among the larger terrestrial mammals are caribou (Rangifer tarandus) of the Porcupine and Central Arctic herds, Dall sheep (Ovis dalli), moose (Alces alces), muskoxen (Ovibos moschatus), grizzly bears (Ursus arctos), black bears (Ursus americanus), polar bears (Ursus maritimus), and wolves (Canis lupus). These species, along with smaller animals, vegetation, and soil organisms, compose the food web of the refuge. 
The polar region of the refuge includes only a subset of the species found within the refuge boundaries, of course. Northward migration of spruce (Picea spp.) forests to the polar region is limited by cold temperatures and the geographic barrier of the Brooks Range (Rupp and others, 2001), and isolated stands of poplars (Populus spp.) are the only trees encountered north of the Continental Divide. Primary production is therefore primarily limited to tundra, lake and lagoon vegetation.

\section{Ecosystem Drivers/Processes}

Harsh climatic conditions during winter result in increased energetic costs for animals, and are compounded by low forage quality and reduced food accessibility, both temporally and spatially (Callaghan and others, 2004). Relatively few wildlife species remain on the refuge coastal plain during winter. Most bird species and some mammals, including the majority of caribou, migrate southward to more hospitable habitats offering shelter and food. Among those that remain, most spend the winter dormant in dens (e.g., grizzly bears, pregnant polar bears, arctic ground squirrels [Spermophilus parryii], and marmots [Marmota broweri]) or are active beneath the snow (e.g., microtines [Clethrionomys spp.] and weasels [Mustela spp.]). Freshwater and anadromous fish move into springfed areas where pools of liquid water occur beneath the ice. A few species remain active above the snow surface throughout the long arctic winter, including the few resident birds and muskoxen. Nonmigratory species must balance food intake with energetic costs of acquiring and processing food and staying warm. In addition to the behavior adaptations noted above, organisms may reduce food intake and activity during harsh weather. Many have insulating fur, feathers and/or fat, and efficient body configurations or other physical, physiological, and behavioral adaptations (Callaghan and others, 2004). Winter conditions occur for two-thirds of the year in the polar regions of Arctic NWR; successful adaptation to these conditions is therefore an essential component of fitness for arctic species.

The short, productive growing season is vital to survival for both resident and migrant species. During the short summer, the sun is above the horizon $24 \mathrm{~h} / \mathrm{d}$, resulting in a boom of growth by primary producers and organisms at lower trophic levels. Many animals enter this season in poor condition after surviving winter or completing a long migration.

\section{Potential Effects of Contemporary Climate Change}

The conceptual ecosystem model for the polar region of Arctic NWR (fig. A2.3) focuses on the arctic coastal plain. The model acknowledges that this region is characterized by great inter-annual variability in weather conditions. Climate change, particularly trends in weather and precipitation, is superimposed upon these stochastic events. Although climate change appears to be a global phenomenon, it is exacerbated at high latitudes (Intergovernmental Panel on Climate Change, 2007), potentially resulting in profound changes to arctic ecosystems (Hinzman and others, 2005). Warming will affect physical processes such as hydrology via changes in precipitation and glacial melt (Nolan and others, 2005). In particular, rates of glacier melt will likely continue to increase, then decrease as glaciers recede, and stream hydrographs will show peaks earlier in the year. Increased temperatures will increase rates of evapotranspiration, which will interact with thawing permafrost to alter surface-water distribution during the ice-free season. Degradation of permafrost is already causing changes in surfacewater distribution on the arctic coastal plain (Jorgenson and others, 2006). Loss of sea ice is resulting in increased coastal erosion (Jorgenson and Brown, 2004). Many changes are expected to exert positive feedbacks on warming, e.g., ice-free ocean absorbs more heat, leading to further ice loss. 
Remote sensing studies have shown a "greening of the Arctic" in the past 30 years, with increased plant biomass and longer growing seasons (Jia and others, 2003). Landscape-scale changes are predicted to increase in the near future, with profound effects on ecosystem functions and feedbacks to climate (Euskirchen and others, 2009). Changes in biological processes such as nutrient cycles and food webs, and altered distribution of plants and animals could reduce food quality, quantity, and availability for many species. For example, shrub expansion into formerly sedge (Carex spp.)dominated tundra (Tape and others, 2006) could reduce habitat quality for some arctic-adapted species, leading to reduced reproduction and survival. Warming is likely to increase the prevalence of diseases, parasites, and other invasive organisms (Kutz and others, 2004). Changes in season length and shifts in phenology could cause food to be unavailable when needs are greatest, e.g., during den emergence or early lactation. Increased winter temperature is expected to increase the frequency of icing events in which rain falling on snow freezes, resulting in crust that creates difficulties for subnivean species and those that forage through snow, such as muskoxen. Winter warming events may damage forage plants by thawing the protective snow cover (Bokhorst and others, 2009). Alternatively, increased winter temperatures and precipitation may increase snow depth, reducing access to food and increasing energetic costs for resident animals. Some primary consumers may benefit from longer, warmer growing seasons, but this may be offset by changes in plant-community structure and composition, and by increases in parasites and disease. As changes occur, some organisms specifically adapted to arctic conditions may decline or disappear while invasive organisms adapted to more southerly conditions may benefit.

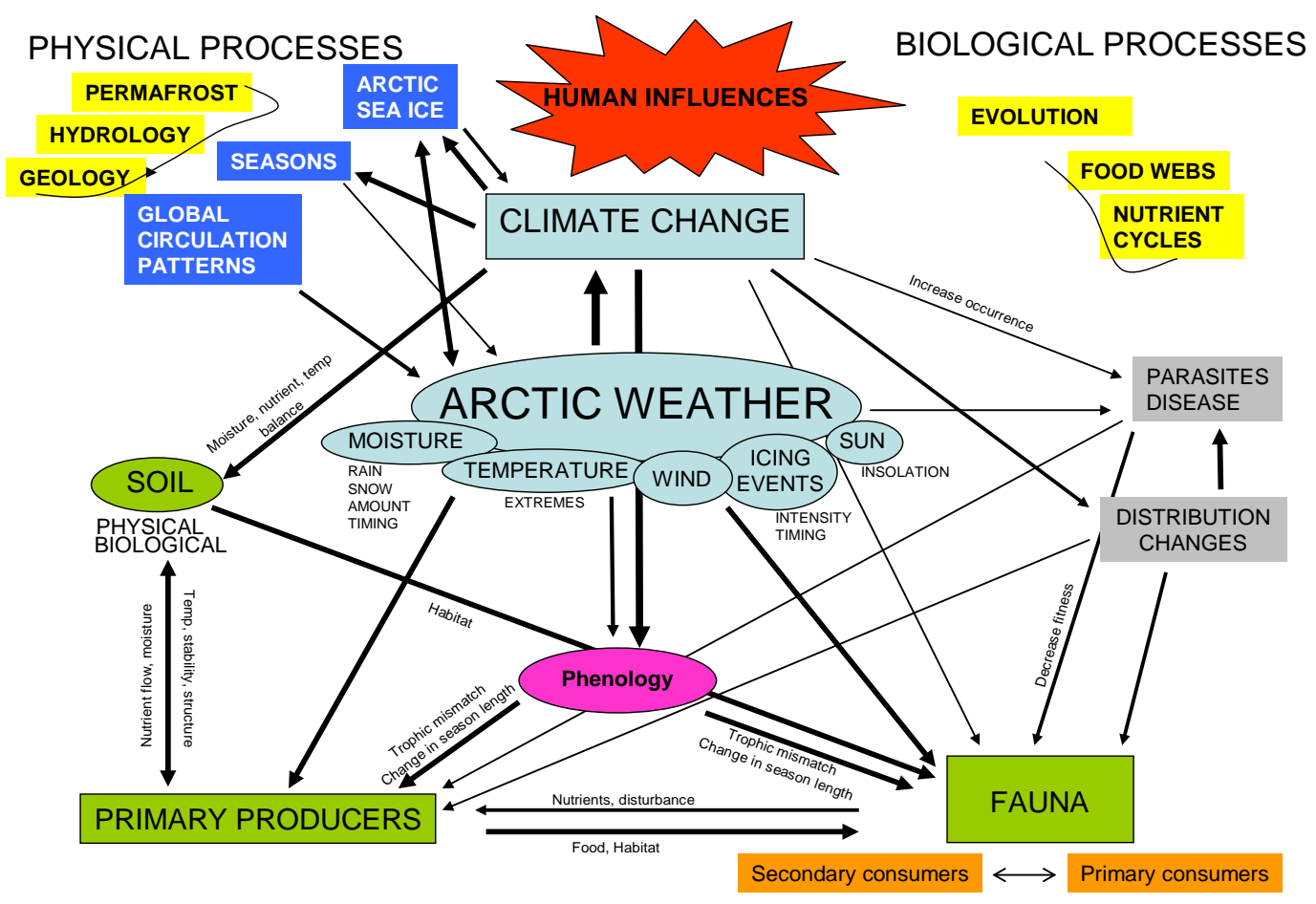

Figure A2.3. Conceptual model of Arctic NWR. 


\section{References}

Borkhorst, S.F., J.W. Bjerke, H. Tommervik, T.V. Callaghan, and G.K. Phoenix. 2009. Winter warming events damage sub-Arctic vegetation: consistent evidence from an experimental manipulation and a natural event. Journal of Ecology 97:1408-1415.

Callaghan, T. V., L. O Bjorn, Y. Chernov, T. Chapin, T. R. Christensen, B. Huntley, R. A. Ims, M. Johansson, D. Jolly, S. Johasson, N. Matveyeva, N. Panikov, W. Oechel, G. Shaver, J. Elster, H. Henttonen, K. Laine, E. Taulavuori, and C. Zockler. 2004. Biodiversity, distributions and adaptation of Arctic species in the context of environmental change. Ambio 33:404-417.

Douglas, D.C., Reynolds, P.E., and Rhode, E.B. (eds.) 2002. Arcitc Refuge coastal plain terrestrial wildlife research summaries, US Geological Survey Biological Science Report, USGS/BRD/BSR2002-0001.

Euskirchen, E.S., A.D. McGuire, F.S. Chapin III, S. Yi, and C.C. Thompson 2009. Changes in vegetation in northern Alaska under scenarios of climate change, 2003-2100: implications for climate feedbacks. Ecological Applications 19:1022-43.

Hinzman, L.D., N.D. Bettez, W.R. Bolton, F.S. Chapin, M.B. Dyurgerov, C.L. Fastie, B. Griffith, R.D. Hollister, A. Hope, H.P. Huntington, A.M. Jensen, G.J. Jia, T. Jorgenson, D.L. Kane, D.R. Klein, G. Kofinas, A.H. Lynch, A.H. Lloyd, D. McGuire, F.E. Nelson, W.C. Oechel, T.E. Osterkamp, C.H. Racine, V.E. Romanovsky, R.S. Stone, D.A. Stow, M. Sturm, C.E. Tweedie, G.L. Vourlitis, M.D. Walker, D.A. Walker, P.J. Webber, J.M. Welker, K.S. Winker, and K. Yoshikawa. 2005. Evidence and implications of recent climate change in Northern Alaska and other Arctic regions. Climatic Change 72: 251-298.

Intergovernmental Panel on Climate Change (IPCC). 2007. Climate Change 2007: Synthesis Report. Intergovernmental Panel on Climate Change, Geneva, Switzerland, 184 pp.

Jia, G.J., H.E. Epstein, and D.A. Walker. 2003. Greening of arctic Alaska, 1981-2001. Geophysical Research Letters 30:31-34.

Kutz, S. J., E. P. Hoberg, J. Nagy, L. Polley, and B. Elkin. 2004. Emerging parasitic infections in Arctic ungulates. Integrative and Comparative Biology 44:109-118.

Nolan, M, A. Arendt, B. Rabus, and L. Hinzman. 2005. Volume change of McCall Glacier, arctic Alaska, USA, 1956-2003. Annals of Glaciology 42:409-416.

Rupp, T.S., Chapin III, F.S., and Starfield, A.M. 2001. Modeling the influence of topographic vbarriers on treeline advance at the forest-tundra ecotone in northwestern Alaska. Climate Change 48:399-416.

Shulski, M. and G. Wendler. 2007. The Climate of Alaska. University of Alaska Press, Fairbanks, $216 \mathrm{p}$.

Tape, K., M. Sturm, and C. Racine. 2006. The evidence of shrub expansion in Northern Alaska and the pan-Arctic. Global Change Biology 12:686-702. 


\section{Appendix 3. BERING COAST ECOREGION - Togiak, Yukon Delta, and Selawik NWRs}

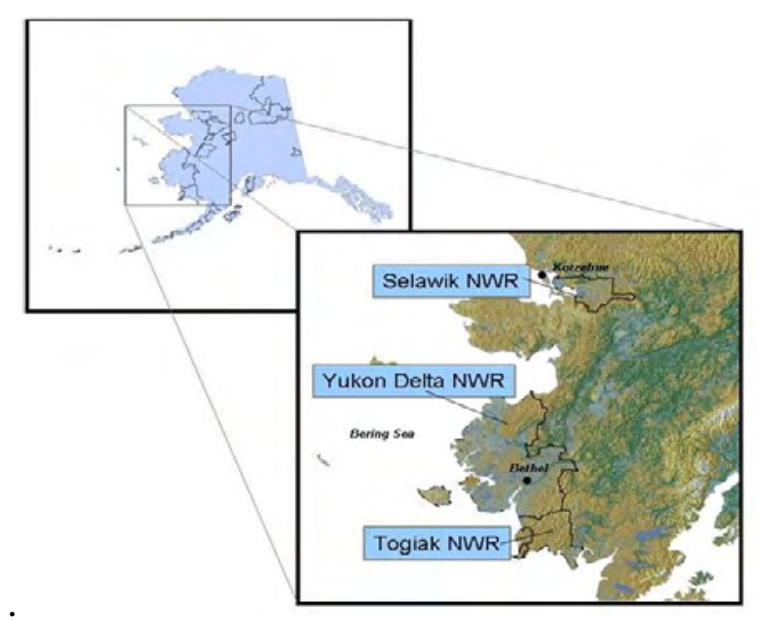

\section{Geographic Context}

Togiak, Yukon Delta and Selawik NWRs collectively cover more than 10.5 million hectares on the west coast of Alaska, and cross more than 8.6 degrees of latitude. They all include delta areas formed where large rivers draining inland areas empty into the Bering Sea. Yukon Delta NWR includes Nunivak Island; Togiak NWR includes glacier-carved peaks in the Ahklun Mountains and some nearshore and intertidal areas. Yukon Delta is the ecoregion's largest refuge and alone includes 9.8 million hectares, which includes 0.93 million acres of Bering Sea bottomlands around Nunivak Island.

\section{Climate}

The west coast of Alaska experiences a maritime climate, especially during summer when the Bering Sea is free of sea ice. Consequently, conditions are moist and rainy, and the temperature range is moderated compared with the more continental interior areas, although climate becomes warmer and wetter as one moves from north to south. Like many portions of the Alaska coastline, the region experiences relatively high winds throughout the year, but especially during autumn and winter, due to frequent storms. However, most of the 250 to $500 \mathrm{~mm}$ of precipitation received annually occurs from June to October.

\section{Abiotic Components}

These refuges contain a diversity of abiotic components. Large and small rivers run through each of the refuges, often terminating in deltas with associated estuarine habitats. Lakes and wetlands are pervasive in these landscapes, and play a tremendously important role in the ecology of many resident and migratory bird species found on the refuges.

\section{Biotic Components}

Several types of vegetation occur on these refuges, including tundra, meadows, riparian corridors, grass/sedge meadows, dwarf birch (Betula pumila), wetlands at lower elevations, and shrubs 
or spruce (Picea spp.), willow (Salix spp.), and cottonwood (Populus spp.) forests at higher elevations. Eelgrass (Zostera marina) beds are an important component of some nearshore areas of Togiak NWR. These habitats host a diversity of wildlife species throughout the year. Invertebrate species are important for their role as a prey base, and also for their herbivory on vegetation within these subarctic ecosystems, which varies in intensity across years. Anadromous fishes include five species of pacific salmon (Onchorynchus spp.); freshwater species include Dolly Varden (Salvelinus malma), trout (Onchorynchus mykiss), arctic char (Salvelinus alpinus), arctic grayling (Thymallus arcticus), northern pike (Esox lucius), and whitefish (Coregonus spp.), among others. Sheefish (Stenodus euchichthys) are an important component of Selawik NWR. Migratory and resident birds are abundant at various time of the year, including shorebirds, waterfowl and raptors on the deltas, songbirds in forests, and seabirds on the coast and Nunivak Island. Marine mammals include several species of whales and seals, Steller sea lions (Eumetopias jubatus), and walruses (Odobenus rosmarus divergens). Terrestrial mammals are also important, and include moose (Alces alces), caribou (Rangifer tarandus), muskox (Ovibos moschatus), black (Ursus americanus) and grizzly bears (Ursus arctos), lynx (Lynx canadensis), red fox (Vulpes vulpes), arctic fox (Vulpes lagopus), wolves (Canis lupus), wolverines (Gulo gulo), mesocarnivores (mink [Mustela vison], marten [Martes ameicana], weasels [Mustela spp.], coyote [Canis latrans], river otter [Luntra canadensis]), little brown bat [Myotis lucifugus], porcupine [Erethizon dorsatum], hares [Lepus spp.], and numerous species of small mammals (e.g., lemmings, mice, voles, shrews [Sorex spp]).

Togiak NWR alone has detected 30 species of terrestrial mammals, and 17 marine-mammal species, as well as more than 200 bird species and 32 fish species. Similarly, Yukon Delta NWR has detected 36 species of terrestrial mammals, 13 marine-mammal species, as well as 242 bird species and 22 fish species (including 7 that are primarily marine) within its borders. Selawik NWR lists 30 terrestrial mammals that have been observed in the refuge.

\section{Ecosystem Drivers/Processes}

The model (fig. A3.1) expresses the importance of climate as the major ecosystem driver, which acts through four primary mechanisms to exert a variety of influences on the natural resources of the refuges. The four mechanisms include changes in the water regime, landforms, temperature periodicity and water/ice dynamics in soil, which each have consequences for habitat and wildlife. Other drivers include human activities, which have local effects (e.g., ATV and snow machine use, infrastructure construction, harvest) as well as global effects on the atmosphere, resulting in climate change and spread of contaminants. Human activities and climate have combined effects on fire regime, which drives changes in terrestrial habitat. Finally, climate can be affected by natural disturbances such as volcanic eruptions, a fairly common occurrence along the Alaska Peninsula and Aleutian Islands.

Terrestrial habitats are affected by climate through the mechanisms of landform change, temperature periodicity and water/ice dynamics in soil. Landform change includes modification of ground structure by erosion, sloughing, and collapsing tundra, which can result from changes in water and ice dynamics in soil, allowing permafrost to thaw. Climate also can affect the frequency of biologically relevant events, such as freeze-thaw switches, extreme-cold events, and droughts. For example, short-term warming trends in mid-winter can cause periodic rain and/or melting. Freezing temperatures then return, causing a hard crust of snow on the tundra, making it more difficult for herbivores to access vegetation. In addition to affecting wildlife population dynamics, including interspecies interactions such as predator-prey cyclicity, there also are consequences for carbon storage and release, and nutrient cycling. 


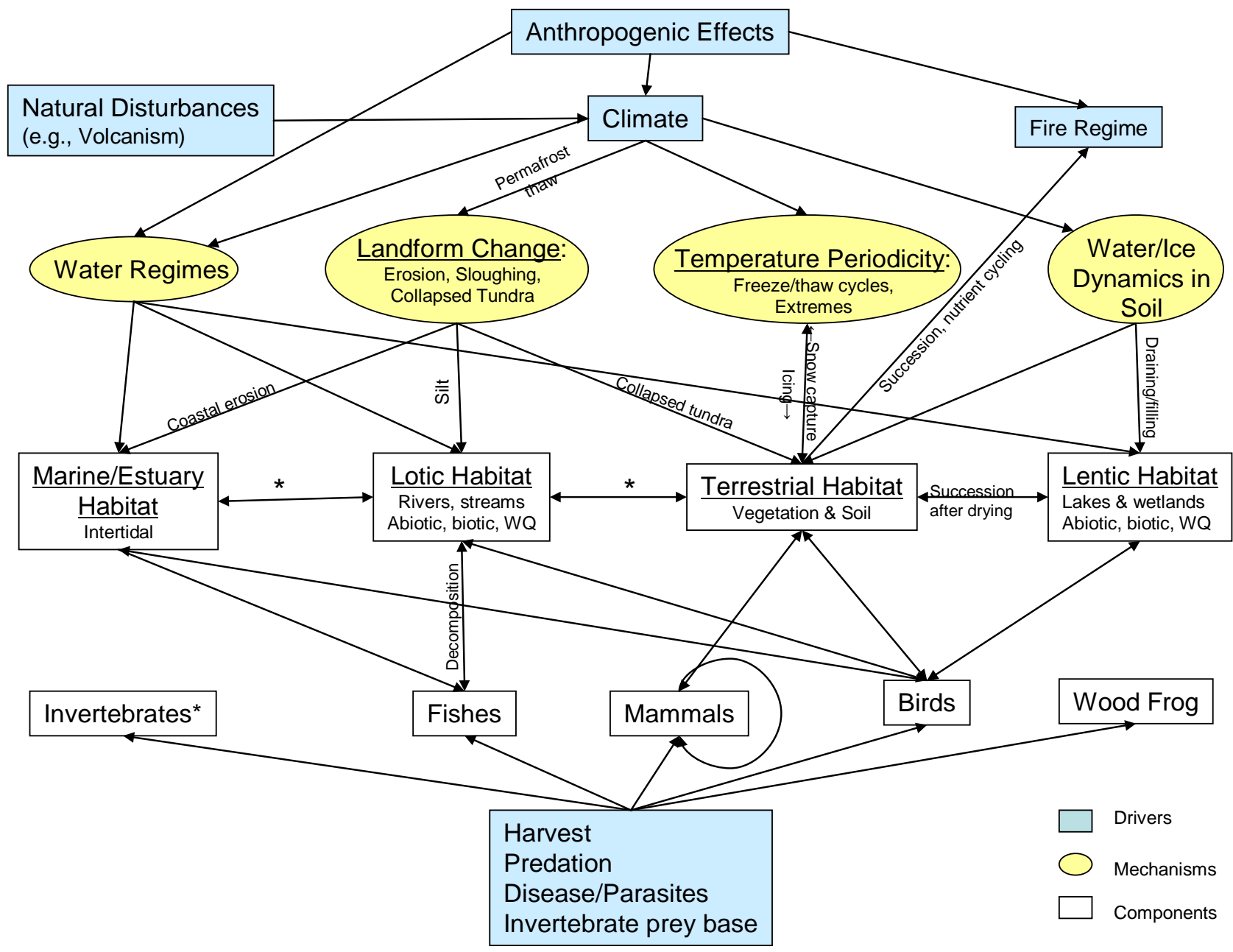

Figure A3.1. Conceptual model of terrestrial ecosystems of refuges in the Bering Coast ecoregion, including Selawik, Yukon Delta and Togiak NWRs. Several important concepts could not be easily diagrammed but should be noted: Dynamics of most boxes are mediated by landscape position and geography (e.g., latitude, longitude, elevation, soil type); invertebrates affect the dynamics of all four habitat types; and soil microbes affect decomposition, which affects transfer of nutrients among all habitat types. 
Marine and estuary habitat is affected by climate through changes in water regime and landforms. These changes impact a variety of wildlife species and other resources important to the refuges and are discussed in the marine ecosystem model (appendix 16).

A concern for lotic habitats is the issue of water quality, which refers to chemical and physical properties, and flow and ice dynamics. Localized threats to water quality include mining and the Bureau of Indian Affairs superfund site near Bethel; more pervasive threats include climate, airborne contaminants, and increased turbidity caused by greater erosion due to thawing permafrost. Soil and bedrock types, stream gradient, elevation, and geographic location are all mediators of how water quality will respond to ecosystem drivers. Changes in water quality will impact important refuge purposes and resources such as providing subsistence fishing, cycling of marine-derived nutrients, and protecting human health.

The availability of lentic habitat can be affected by climate through its effects on the amount of snow and rain and through permafrost thawing, which may also influence drying or filling of lakes and ponds. Changes in lake systems can, in turn, cause changes in soil properties and allow accelerated or decelerated rates of successional changes in vegetation communities. Diminishing water levels in rivers and lakes may also affect the wildlife species that depend on them. For example, shallower areas may attract dabbling ducks and shorebirds, while displacing other species.

Fire also serves as a driver on the refuges, and is itself driven by climate and human activities. The primary impact of fire is to convert sedge-dominated tundra to grasses, which impacts nutrient cycling and food availability for herbivores (including ungulates, hares, waterfowl and bears). In turn, altered herbivore guilds will ultimately affect predators.

\section{Potential Effects of Contemporary Climate Change}

One concern for river habitats is that higher water temperatures caused by increasing temperatures and/or low water may affect fisheries resources, directly and through secondary effects such as algal blooms. In addition to being a unique ecosystem, the lotic environment connects terrestrial and marine environments through the mechanism of landform change. Effects of soil erosion may include sloughing into rivers; beach and streambank erosion; and terrestrial slumping or sinkholes. In turn, this erosion can affect water quality via increased siltation rates, and habitat quality of streams for fishery and terrestrial systems via altered water-table levels. In addition, lotic systems convey freshwater to marine systems and marine-derived nutrients to freshwater and terrestrial systems via anadromous fish.

Climate change may have particular impacts on animal and fish migrations, including causing individuals of Neotropical landbirds, shorebirds, waterfowl, caribou, and anadromous fish species to arrive earlier to arctic and subarctic habitats earlier than they have in recent decades. Temperature changes can affect migratory animals by changing the timing and availability of food, water, cover, and other resources. Moreover, temperature can possibly trigger earlier or later migrations of species either immigrating to or emigrating from refuges. Finally, temperature changes can affect disease and pest dynamics; in northern ecosystems, increasing temperatures will likely permit increases in intensity and diversity of disease and pest outbreaks. 


\section{Appendix 4. INTERIOR ALASKA ECOREGION - Innoko NWR}

By Steve Kovach, Supervisory Biologist, Innoko NWR

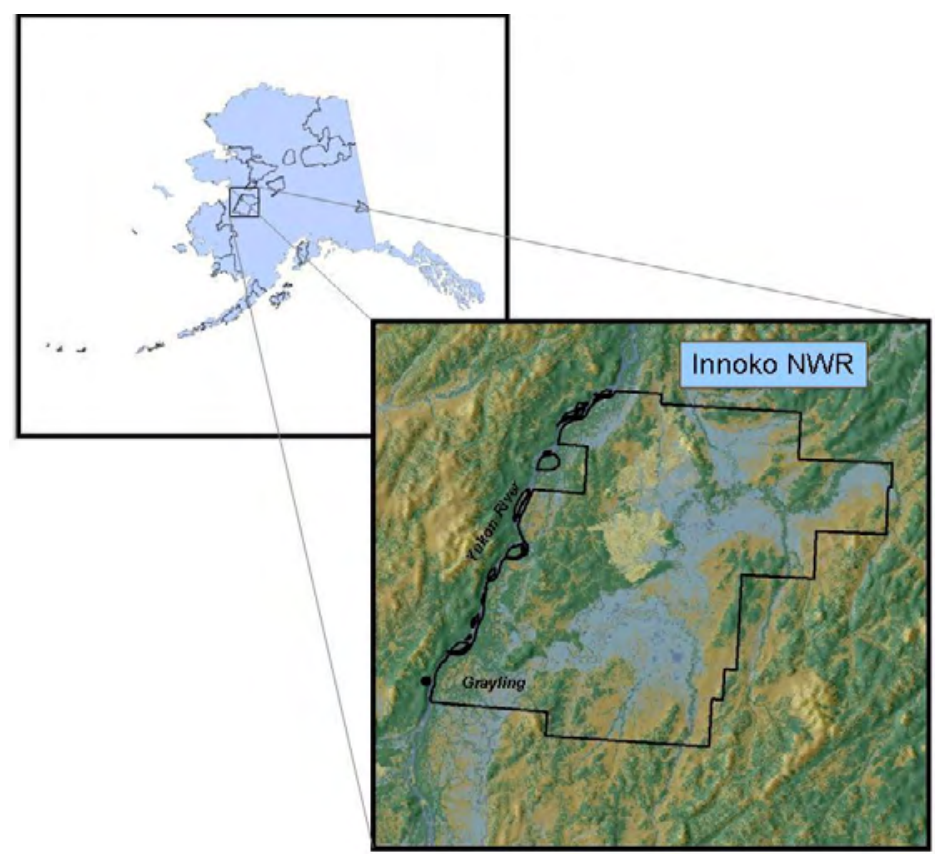

\section{Geographic Context}

Innoko NWR is located in the roadless southwestern part of Interior Alaska. The western boundary of the refuge is formed by $110 \mathrm{mi}$ of the Yukon River; its floodplain dominates the western portion of the refuge. The Yukon River floodplain is separated from the rest of the refuge by the Fox and Kaiyuh Hills, which are dominated by the Innoko River drainage. Portions of major tributaries to the Innoko River (Dishna River, Hather Creek, Iditarod River, and Mud River) also are within the boundaries of the refuge. The Innoko River meanders diagonally through the refuge from the northeast to the southwest. The Kuskokwim Mountains are located to the south and east of the refuge.

Physiographic relief is minimal, with elevations ranging from $55 \mathrm{ft}$ along the Yukon River to a high of 1,461 ft in the Fox Hills. Large basins dominated by wetlands, bogs, and muskegs are found associated with Hather Creek, Iditarod River, and Mud River. These basins, as are all the tributary watersheds, are separated by low rolling hills.

\section{Climate}

Innoko NWR has a continental subarctic climate characterized by low annual precipitation, low humidity, low cloudiness, and large diurnal and annual temperature ranges. The summer sun provides almost continuous radiation and heats the valleys. On the summer solstice, the sun is above the horizon for slightly more than 20 hours. In winter, the valleys become cold sinks; on the winter solstice, the sun 
is above the horizon for less than 4 hours. Temperatures recorded at the Anvik airport automated weather station (1993-2007) indicate an average daily temperature of $2^{\circ} \mathrm{F}$ in January and $57^{\circ} \mathrm{F}$ in July.

Freeze-up on the Yukon River at Holy Cross (42 mi south of the refuge) usually occurs in late October to early November; breakup is usually in early to mid-May. Ice generally is present in the lakes and sloughs from early October through late May.

Snow depths across the refuge shows both an east-west and north-south gradient (least to greatest, respectively). Early February through early April generally have the deepest snow depths recorded, averaging 28.9-34.4 in.

\section{Abiotic Components}

Innoko NWR is located within the Yukon-Koyukuk geologic province, a "basin" of volcanic origin. The province generally is composed of andesitic volcanics, which overlies mafic (basalt and gabbro) and ultramifc (gabbro and olivine) rock. Low areas are filled with sediments primarily of igneous origins. Perimeters of the basin are composed of metamorphosed continental rock.

Soils are a product of the geologic parent materials. Based on a course scale survey (Reiger and others, 1979), soils in the refuge are relatively uniform with poorly drained, peaty silt to slit loams. The soil surface tends to be hummocky, with accumulations of peaty materials. Organic soils have been documented in various parts of the refuge ranging from 2 to 36 in. in depth.

The refuge is believed to be largely underlain by discontinuous permafrost (occupying 50-90\% of the area) with only medium amounts of ground ice (10-20\%) in the upper $66 \mathrm{ft}$ of the soil (Brown and others, 2001). The Yukon River floodplain area is believed to be underlain by an area of continuous permafrost. There is no reason to believe that the permafrost found in this area is any different from permafrost in other portions of Interior Alaska; there, permafrost temperatures generally are $28-31^{\circ} \mathrm{F}$.

The poorly drained soils typically present on the refuge, combined with the cold winter temperatures, contributes to the formation and maintenance of permafrost. That much of the refuge is believed to be underlain by discontinuous permafrost adds a degree of complexity when attempting to determine changes in its extent from one time period to another. No repeat visit studies have ever been conducted on the refuge specifically examining presence, extent, characteristics, or changes to permafrost. Presence of permafrost is believed to be responsible for the maintenance of water in "bog" lakes (lakes with no outlet or connection to river systems).

Sedimentation in the Dishna River, Iditarod River, Innoko River, and Mud River have all been substantially increased by placer mining activities in the region over the last 103 years.

\section{Biotic Components}

The model (fig. A4.1) divides the biotic components into hydrology, vegetation, and animals. For the model and this discussion, hydrology is limited to surface systems as nothing is known about subsurface systems on the refuge or the region.

Hydrologic components are broadly broken into lotic and lentic systems. Lotic systems are broadly broken into permanently flowing and intermittently flowing. There are more than 7,100 mi of lotic systems on Innoko NWR, not including the Yukon River. Lentic systems are broadly broken into those with outlets to lotic systems and those without any outlets. There are more than 22,800 lentic systems within the refuge. Permanently flowing lotic systems appear to be more biologically productive and diverse than intermittently flowing systems; likewise, lotic systems with outlets appear to be more productive than those without. 


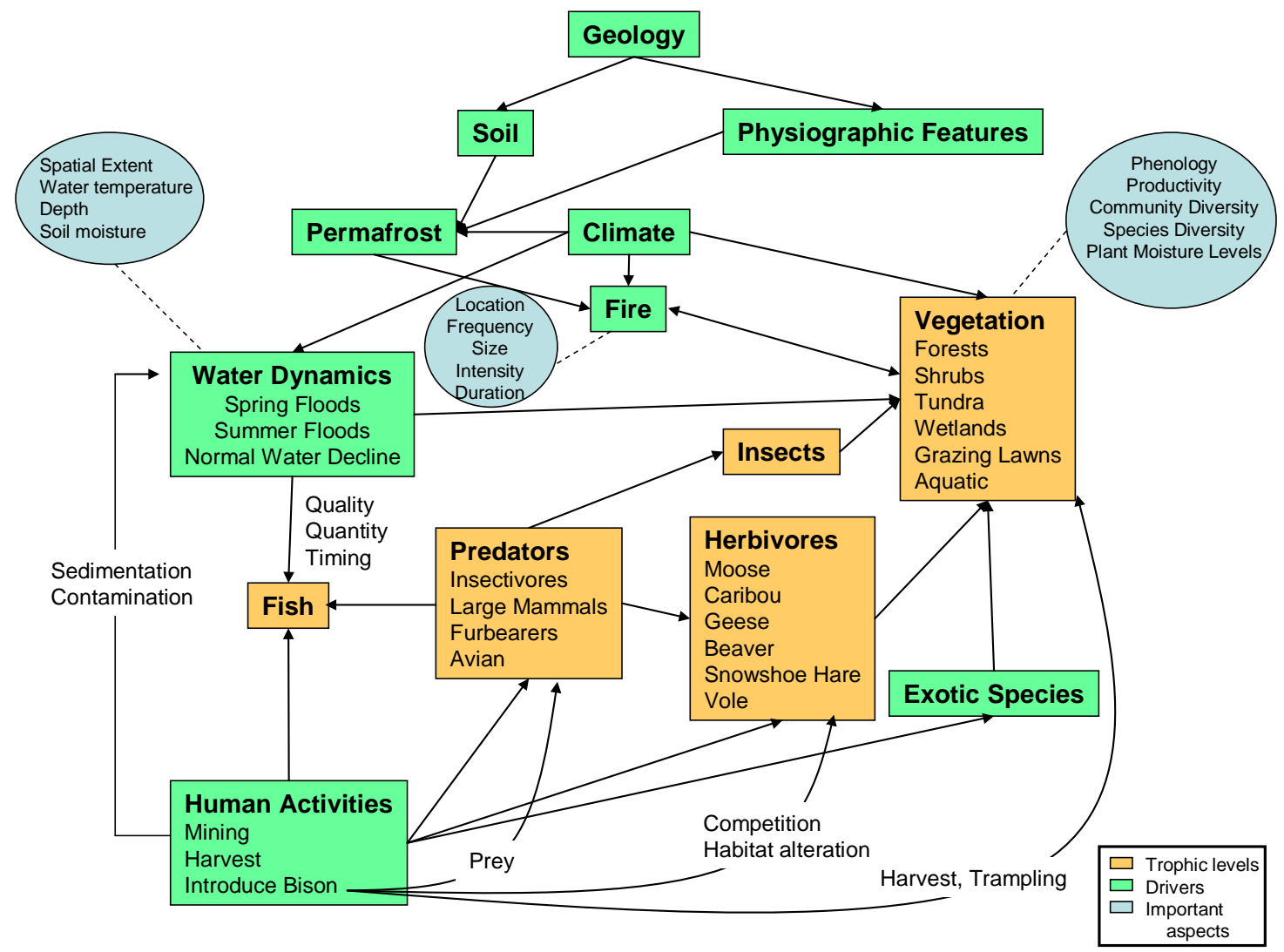

Figure A4.1 Conceptual model of Innoko NWR

The model identifies six vegetation classes (fig. A4.1). Forests are composed of: needleleaf forests and woodlands dominated by black spruce (Picea mariana) and white spruce (Picea glauca), with some tamarack (Larix laricina); broadleaf forests and woodlands dominated by paper birch (Betula papyrifera), aspen (Populus tremuloides), balsam popular (Populus balsamifera), and alder (Alnus spp.); and mixed needleleaf-broadleaf forests. Shrubs include both tall ( $>3 \mathrm{ft}$ ) shrubs dominated by willow (Salix spp.) and short shrubs dominated by dwarf birch (Betula nana), Labrador tea (Ledum groenlandicum), bog blueberry (Vaccinium uliginosum), and crowberry (Empetrum nigrum). Tundra dominated by tussock cottongrass (Eriophorum vaginatum), dwarf birch, Labrador tea, bog blueberry, and reindeer lichens (Cladina mitis). Emergent wetlands are dominated by willow, sedges (Carex spp.), horsetails (Equisetum spp.), and clubmosses (Lycopodium spp.). Grazing lawns are an important subset of herbaceous meadows dominated by bluejoint grass (Calamagrostis canadensis), polar grass, fescue (Festuca ovina), and bluegrass (Poa spp.). Aquatic vegetation includes the showy pond lily (Nuphar polysepalum) as well as many types of submerged vegetation. Aquatic vegetation composition is the poorest understood of the vegetation classes on the refuge.

Animals are broadly broken down into invertebrates, fish, predators, and herbivores. With the exception of those causing damage to vegetation, invertebrate communities on the refuge are largely unknown. 
Fish include 9 anadromous and 13 non-anadromous species. Anadromous species include salmon (Onchorynchus spp.) and various whitefish (Coregonus spp.). Salmon no longer spawn within the refuge, but do spawn in the upper reaches of the Dishna, Iditarod, Innoko, and Mud Rivers. Northern pike (Esox lucius) are believed to be the most abundant and widely distributed non-anadromous species on the refuge.

Thirty-eight mammals are known or believed to exist on the refuge. For purposes of the model, mammalian predators include the diminutive insectivores represented by the shrews (Sorex spp.), large predators (consisting of brown bear [Ursus arctos], black bear [Ursus americanus], and wolf [Canis lupus]), and furbearers consisting of lynx (Lynx canadensis), marten (Martes americana), river otter (Lontra canadensis), and wolverine (Gulo gulo). The refuge has documented 128 avian species. For purposes of the model, avian predators include bald eagle (Haliaeetus leucocephalus), osprey (Pandion haliaetus), northern harrier (Circus cyaneus), northern goshawk (Accipiter gentilis), great horned owl (Bubo virginianus), and great grey owl (Strix nebulosa).

For purposes of the model, mammalian herbivores include moose (Alces alces), caribou (Rangifer tarandus), beaver (Castor canadensis), snowshoe hares (Lepus americanus), and voles; avian herbivores include greater white-fronted geese (Anser albifrons), Canada geese (Branta canadensis), and cackling geese (Branta hutchinsii).

\section{Ecosystem Drivers}

We began with a long list of ecosystem processes and drivers, but settled on the simplified system depicted in figure A4.1. Geology is at the root and is acted upon by four principal drivers: climate, hydrology, fire, and human activities. Each of these drivers not only act independently but in various combinations as well as in interactions with some or all of the others at any given time.

Climate.-Climate is always in a state of flux and is never in a state of equilibrium. It is the rate of this natural flux that is believed to be affecting hydrology, fire, and vegetation. The direction that the climate is shifting influences major components of the other system drivers - specifically hydrology and fire. The direction and rate that the climate is shifting also has a major influence on vegetation communities which in turn influence invertebrate and vertebrate populations.

Hydrology.-Flood events come at two different times: in spring driven by breakup; and summer driven by storms. Spring floods result from rising water levels driven by snow melt. The extent of flooding is increased when ice dams are present. Ice dams generally occur either on the Innoko River or the Yukon River, occasionally on both. Ice dams on the Innoko River above Grouch Creek affect smaller basins (e.g., No Name Creek, Hather Creek, Mud River) whereas ice dams downstream of the Iditarod River but upstream of Holikachuk affect the Iditarod River basin. Ice dam driven floods are larger in extent than those associated just with high water levels; the lower down a river the ice dam occurs, the larger the extent of the flooding. Spring flood waters tend to be colder in temperature, deliver nutrients (including woody debris), deposit sediments, and recharge wetlands with "new" water. Prolonged standing flood waters are believed to slow the rate of seasonal soil warming that results in: delayed start of growth for herbaceous vegetation; reduced rate of early season growth for woody vegetation; and likely reduces the depth of the active layer for the season, particularly if standing water is present for a prolonged time. Prolonged flood waters prevent water levels from lowering which can affect not only the obvious (primary production) but the not so obvious (such as moose calving and waterfowl nesting) as well. Water depth naturally fluctuates in the connected sloughs, rivers, and lakes. With lowering water levels in mid- to late-June low angle shorelines are exposed along rivers and lakes which provide seasonal grazing habitat for greater white-fronted, Canada geese, and cackling geese; without exposed grazing habitat, geese are forced to forage further away from water to feed on lower 
quality forage. Spring floods can disrupt herbaceous vegetation by setting back the onset of growth and smothering with sediments. Woody vegetation can be physically impacted by ice and prolonged flooding prevents berry bushes from blooming. Spring flooding does enable water exchange between: bog lakes and rivers; and beaver dammed areas and rivers. This water exchange also enables exchange of fish, both species and age cohorts, between river and beaver dammed areas (Brown and Fleener, 2001).

Summer floods result from heavy precipitation in various parts, or throughout the Innoko River watershed. Summer flooding extent is reduced from that of spring floods. Although summer floods also deliver nutrients (including woody debris) and sediments, the relative temperature of the water is warmer compared to spring flood waters. Summer floods can extend surface-water availability, and overall depth, compared to those summers where receding water levels dominate the hydrology. Summer flooding can make goose grazing habitat unavailable. Like spring floods, summer floods can disrupts herbaceous vegetation and leaves of woody vegetation by covering with sediments. Berry bushes may loose fruit due to summer standing water.

Overall frequency, timing, and extent of spring and summer flood events are largely unknown as no water gaging stations have ever been installed on the Innoko River and have been in place intermittently on the Yukon River in the vicinity of the refuge.

Water quality is affected by increased sedimentation due to upstream placer mining activities. Water quality also may be negatively affected by the introduction of dissolved chemicals derived from upstream placer mining activities. Additionally, proposed road developments to support regional mining activities could provide additional discharge points for reduced water quality.

Fire.-History has shown that fire locations are dramatically affected by physiographic positioning — drier upland habitats have been most the frequently burned habitats burned since 1957 whereas wetter lowland areas have been infrequently burned. Fire directly affects vegetation and indirectly affects the invertebrates and vertebrates dependent on that vegetation. Lower intensity fires burn trees and shrubs, but leave ground cover largely intact; these fires tend to favor direct reestablishment of needleleaf forests. Higher intensity fires on the other hand burn trees, shrubs, and ground cover. Higher intensity fires promote a change in the habitat type by favoring establishment of hardwood forests before transitioning back to needleleaf forests. Standing trees after the fire are susceptible to wind throw effects, particularly those from higher intensity fires.

The refuges' remote location has lead to little intervention in wildfire activity by humans. This remote location also is likely the reason that virtually all fires on and adjacent to the refuge are from natural ignition sources.

Wildfires have been shown to have only short-term impacts to water quality.

Human.-Current human activities include: harvesting a variety of birds, fish, and mammals; harvesting berries, firewood, and house logs; direct degradation of habitats through the use of snowmachines when less than 12 in. of snow is present and indirectly through snow and soil compaction; sedimentation and dissolved chemicals loads from upstream mining activities; possible contaminants from current upstream mining activities as well as left over remains from historic mining related activities; introduction of exotic plant species; and research and management activities conducted by refuge staff and partners. Potential future impacts come from three sources - the proposed introduction of wood bison (Bison bison athabascae), unintentional introduction of additional exotic plant species, and mineral extraction. 
If wood bison are introduced into the Innoko ecosystem, it brings in a mammalian grazer that has not existed at least since 1838 (when the first Russian explorers documented going up the Innoko River). Before and after effects studies have never been completed for wood bison; therefore, all possible effects are purely speculative in nature. Possible effects include: competition with moose for various resources; changes to terrestrial plant communities which would possible precipitate changes to the breeding bird communities, the small mammal community, and avian and smaller mammalian predator communities; and possible competition with or displacement of geese from seasonal grazing habitats.

Mineral extraction related activities include: construction of planned roads; expanded mining activities; and incomplete or inadequate reclamation of abandoned mining sites. Road construction activities could result in sedimentation and accidental introduction of contaminates. Use of roads once completed, are likely to result in increased opportunities for sedimentation, introduction of contaminates, introduction of dissolved chemicals, human activities on rivers (e.g., rafting, boating, hunting), and introduction of additional exotic plant species. Expanded mining activities include both the opening of new sites as well as expansion of existing sites. Incomplete or inadequate reclamation of abandoned mining sites can result in runoff of sediments, contaminants, and/or other chemicals as well as the introduction of additional exotic plant species.

\section{Potential Effects of Contemporary Climate Change}

Climate is an important driver in this model (fig. A4.1). Obviously any changes to climate from the current state will have interactive effects on the other drivers which would precipitate an unknown number of changes. The literature contains models that forecast both a contemporary warming (e.g., Rupp and Springsteen, 2009) as well as a cooling climate (Tsonis and others, 2007; Swanson and Tsonis, 2009) for Alaska.

Contemporary changes due to warming climate may include changes to permafrost (depth, distribution, and active layer depth), surface water abundance and distribution, reduced winter ice depths and associated breakup influences, terrestrial vegetation (composition and distribution), and increased wildfire activity. Contemporary changes due to a cooling climate may include similar but opposite affects from a warming climate.

\section{References}

Brown, R.J. and C. Fleener 2001. Beaver dam influence on fish distribution in lentic and lotic habitats in the Black River drainage, Alaska. Unpublished USFWS report, Fairbanks, Alaska. 42 pp.

Reiger, S., Schoephorster, and Furbush, C.E. 1979. Exploratory soil survey of Alaska. U.S. Department of Agriculture, Soil Conservation Service, Washington, D.C.

Rupp, T.S., and A. Springsteen. 2009. Summary report for Innoko National Wildlife Refuge: Projected vegetation and fire regime response to future climate change in Alaska. Unpublised USFWS report, Fairbanks, Alaska. 35 pp.

Swanson, K. L., and A. A. Tsonis. 2009. Has the climate recently shifted? Geophysical Research Letters, 36, L06711

Tsonis, A. A., K. Swanson, and S. Kravtsov. 2007. A new dynamical mechanism for major climate shifts. Geophysical Research Letters, 34, L13705. 


\title{
Appendix 5. INTERIOR ALASKA ECOREGION-Kanuti NWR
}

\author{
By Lisa Saperstein, Supervisory Biologist, Kanuti NWR
}

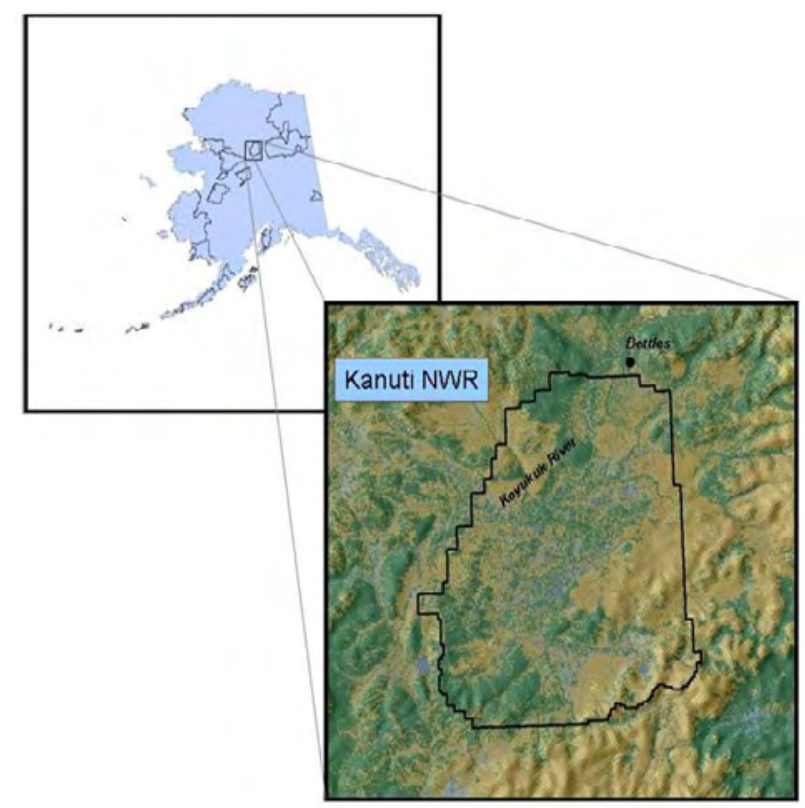

\section{Geographic Context}

The refuge is roadless and lies on the Arctic Circle between the Brooks Range and the Ray Mountains in a broad basin formed by the Koyukuk and Kanuti Rivers. The lands and waters within the refuge are linked to the Bering Sea through the Koyukuk River, which drains into the Yukon River and then into the Bering Sea. The refuge's external boundaries encompass approximately 1.6 million acres of Federal, State, and private lands. The landscape consists primarily of rolling hills, wetlands, ponds, and streams. Elevations range from 500 to more than 3,000 ft.

\section{Climate}

The area has a continental climate and receives slightly more precipitation than other areas in interior Alaska. Summers are short with moderate temperatures; winters are long and cold.

Temperatures span some of the widest extremes on earth, ranging from more than $90{ }^{\circ} \mathrm{F}$ in summer to $-70{ }^{\circ} \mathrm{F}$ in winter. Spring and fall are brief seasons that begin and end abruptly.

\section{Abiotic Components}

The refuge is underlain by discontinuous permafrost, and any changes in permafrost status will have far-reaching effects on habitat and wildlife. Permafrost is noted in red text in the model because it is strongly influenced by climate (fig. A5.1). Discontinuous permafrost is particularly sensitive to temperature changes because its temperature is only slightly below freezing (Hinzman and others, 2006). Thus, observed and predicted increases in temperature and incidence of fire will fundamentally affect the status of permafrost on the refuge. Surficial geology, soils, permafrost, and topography dictate 
the distribution of different plant communities. Underlying geology, such as the presence of precious metals or energy sources, may lead to human disturbance within the refuge or in adjacent areas. There is currently no mining in the refuge but historical mining occurred in the late 1890s into the early 1900s.

\section{Biotic Components}

Other components of the model (fig. A5.1) include terrestrial vegetation classes; aquatic habitat classes; invertebrates; vertebrates (mammals, birds, and fish); and human activities that incorporate human use of the refuge as well as laws and mandates that affect the refuge directly or indirectly. Terrestrial habitat can be broken down into relatively broad classes based on Viereck and others (1992) classification of Alaska's vegetation. Each of the broad vegetation classes (forest, shrub, herbaceous) can be further broken down into numerous communities based on life form (e.g., conifers or hardwood trees in the forest classes; moss, lichen, or forb dominance in the herbaceous class) and canopy cover (open, closed, woodland), but these have been omitted from the model for the sake of simplicity. Likewise, aquatic communities have been simply divided into rivers, permanent wetlands, and ephemeral wetlands.

Aquatic and terrestrial habitats give rise to the invertebrate and vertebrate species found on the refuge. Invertebrates are not included with fish and wildlife due to their lower trophic level, their ability to respond quickly to climate change due to short generation times and high productivity, and their potential to widely influence both habitat (e.g., defoliation) and fish and wildlife populations (e.g., disease transmission). As with habitat, each of the faunal components has been roughly broken down into broad groupings based on trophic status (mammals), migratory status (fish), taxonomy (birds), or life form (invertebrates).

\section{Ecosystem Drivers}

Climate, fire, and hydrology have been identified as the primary ecological drivers of ecosystems within Kanuti NWR (Heglund and others, 2005; fig. A5.1). They are interrelated because climate strongly influences and regulates the drivers of fire and hydrology.

Fire and flooding are the two primary causes of disturbance on the refuge. Approximately 70\% of the refuge lies within $<60$-year old burns, according to fire perimeter maps dating from 1950 to the present. Almost all fires on Kanuti NWR are naturally ignited, but humans dictate suppression practices and there are several different prescriptions for fire management within the refuge. Flooding of rivers and lakes is closely tied to winter snowfall and river ice conditions during spring break-up. However, flooding is also possible during periods of high rainfall in summer and fall. Water levels in rivers and lakes are not manipulated by humans on Kanuti Refuge. There are no dams or impoundments, and any water drawn from rivers for human use occurs near villages just outside of the refuge boundaries. Incidence of aquatic contaminants is thought to be minimal on the refuge, but they may be introduced from upstream sources such as villages, the Trans-Alaska Pipeline, or the Dalton Highway or from airborne pollution. 


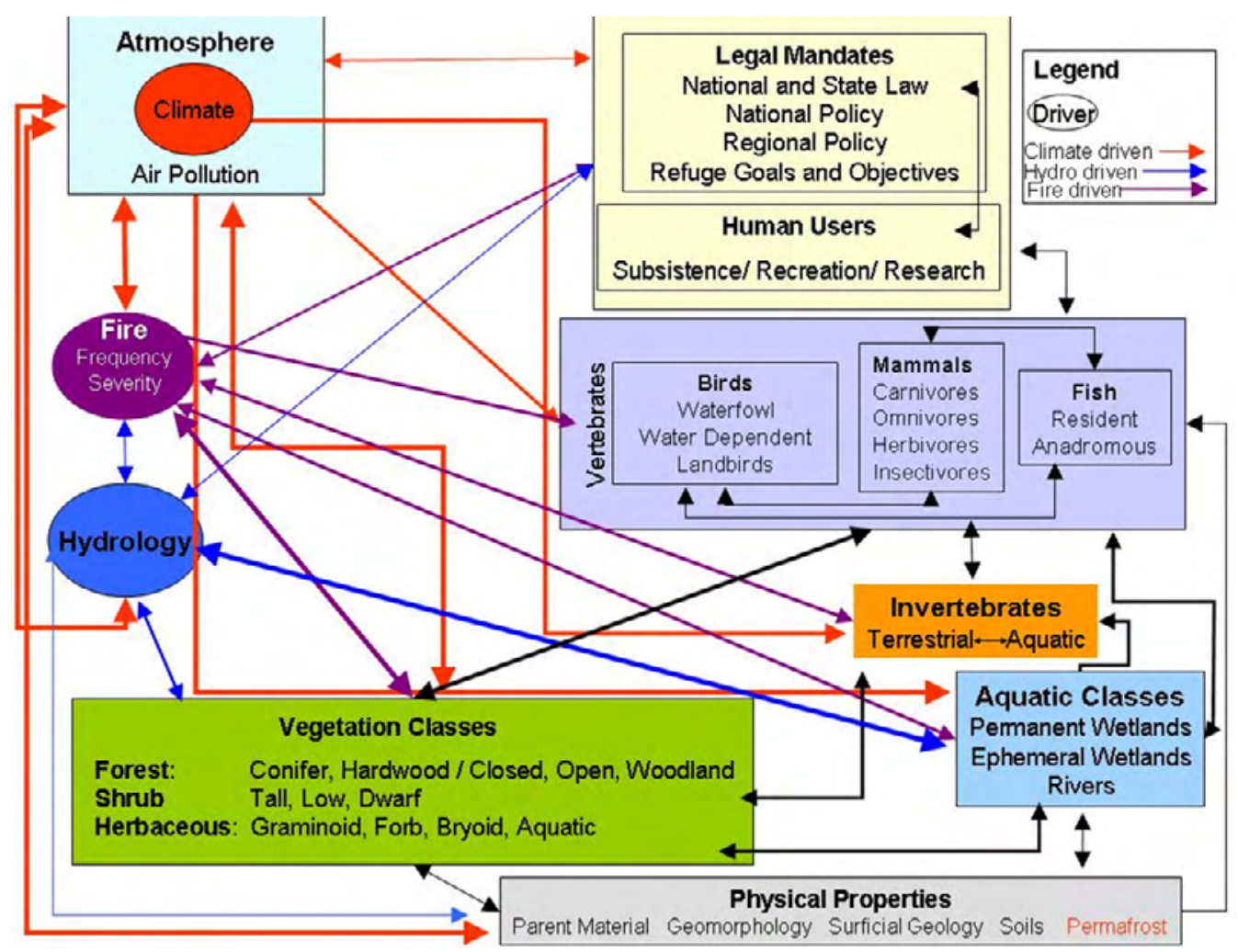

Figure A5.1. Conceptual model of Kanuti NWR. Drivers are on the left and contained in circles; non-driver components are displayed in boxes. Arrows illustrate relationships among and within drivers and components; thicker arrows represent stronger relationships. Components and relationships are distinguished by having a likely direct response to climate change (red) or possibly indirect response (others). Arrow colors indicate direct effects of hydrology (blue), direct effects of fire (purple), or general relationships (black).

Vegetation and populations of invertebrates and vertebrates are affected directly by ecological drivers and by the effect of drivers on habitat. Fire and flooding can be sources of direct mortality and can also influence the ability of terrestrial and aquatic habitats to support different species. For example, a fire in old ( $>80$ years) black spruce (Picea mariana) forest can remove old-growth lichens favored by caribou (Rangifer tarandus) as winter forage (Rupp and others, 2006), but may result in increased production of willows used as forage by moose (Alces alces; Maier and others, 2005). Interactions also occur among non-driver model components, including the following: Browsing, grazing, and defoliation of vegetation by wildlife and insects; spread of fish and wildlife diseases by invertebrates; and introduction of marine-derived nutrients into terrestrial systems by spawning salmon. Numerous interactions among humans and other model components are also possible. Species and density of wildlife will determine if people want to visit the refuge for wildlife viewing or hunting, aquatic and terrestrial habitats influence if and where people want to camp or boat on the refuge, and underlying physical factors affect the desirability of an area for recreational pursuits (e.g., hiking conditions) or economic uses (e.g., mining). Furthermore, there are intra-component effects, such as predation among vertebrates, as indicated by the black arrows within component boxes (fig. A5.1). 
Components can also feed back to the drivers, resulting in numerous double arrows between the two (fig. A5.1). Examples include the impact of beaver (Castor canadensis) activity on hydrology; tree mortality due to repeated insect defoliation that increases fuel loads and heightens the risk of fire; and changes in surface albedo resulting from long-term changes in dominant vegetation type that can influence climate (Chapin and others, 2005).

\section{Potential Effects of Contemporary Climate Change}

A warming climate will directly influence many components of this model (fig. A5.1). Climate effects on other drivers will trickle down to other components, some of which have been noted above. Fire activity is predicted to increase in interior Alaska under a warming climate, with increased frequency, and possibly severity, of fire compared to previously recorded trends. This will result in more deciduous vegetation on the landscape compared to historical conditions (Rupp and others, 2002; Rupp, 2008), which will subsequently influence the future fire regime (Rupp and others, 2002) as deciduous vegetation is less likely to burn than conifers. A Kanuti NWR-specific fire model incorporating four different climate models over a 100-year period supported this shift to deciduous vegetation with a decline in older spruce (Picea spp.) habitat (Rupp and others, 2007).

Although climate models predict an increase in precipitation in interior Alaska, predicted increases in evapotranspiration rates will counteract this and result in a drying trend for soil moisture and a reduction of runoff in river basins without large glaciers (Hinzman and others, 2005). In addition, lakes and rivers may undergo chemical changes for a variety of reasons as temperatures increase, including increased weathering of exposed material, changes in the chemical composition of precipitation, or increased subsurface flow through the active layer (area of seasonally thawed ground) (Hinzman and others, 2005). Water chemistry may also change as increased amounts of methane are released and other chemicals become more available.

Permafrost prevents surface water from infiltrating into the ground (Hinzman and others, 2005), creating or maintaining water bodies and wet surface conditions. Therefore, degradation of permafrost can increase infiltration and drain lakes. Coupled with a water deficit due to increased evapotranspiration, this can result in drier surface conditions which, in turn, can lead to changes in vegetation and increased risk and severity of fire. Expedited drying of lakes, which are already shallow and appear to be shrinking in surface area on the refuge, has been seen in other areas of interior Alaska (Riordan and others, 2006). Conversely, the surface area of lakes may increase with thawing of permafrost due to erosion and surface subsidence around the edges of existing shorelines. In steeper areas, surface subsidence can result in landslides, erosion, and sedimentation in lakes and rivers.

Aquatic communities on the refuge will also change in ways other than water quantity in response to a warmer climate. The incidence of eutrophic lakes may rise with increased production of aquatic plants and other organisms, leading to a subsequent change in use of these wetlands by fish and wildlife species. Decreases in lake depth may increase the incidence of lakes freezing to the bottom, making them unsuitable for some species of fish, wildlife, and invertebrates. Lower water levels may also reduce the number of lakes that are connected to rivers or the timing of such connections, restricting access for fish and limiting nutrient exchange.

Climate change can impact Kanuti Refuge's plant communities and their associated fauna in a number of other ways. Predicted expansion of forest into tundra habitat (McGuire and Chapin, 2006) may lead to disappearance of the refuge's already minimal acreage of upland tundra as treeline moves uphill. As mentioned earlier, increased fire will result in a prevalence of early seral stages. This represents a loss of habitat for wildlife dependent on older stands but it precipitates increased opportunities for those species that utilize earlier successional habitats. Repeated fires at short intervals 
may result in a permanent type-conversion of plant communities. Some researchers predict that drier, warmer conditions will cause physiological stress in certain plant species in Alaska such as white spruce (Picea glauca) that could lead to a population decline (Juday and others, 2005) and subsequent loss of habitat for associated wildlife. Such changes in forest health can increase the susceptibility of forest stands to insect pests (Werner and others, 2006), resulting in tree mortality and increased fire risk. Other plant species may benefit from warmer temperatures, a longer growing season, and increased depth of the active layer that can facilitate drainage, free up existing nutrients for plants, and stimulate the activity of soil microfauna that can further increase soil fertility. These species may include non-native, invasive species that are a threat to refuge resources. The primary invasive plant species of concern for the Kanuti area at this time is white sweetclover (Melilotus officinalis), which has infested the Dalton Highway corridor to the east and could spread onto the refuge via the numerous rivers and streams that cross the highway and flow through the refuge. Bird vetch (Vicia cracca) is another potential threat that has increased in the Fairbanks area in recent years and has become established in several areas along the Dalton highway. Finally, plant phenology also can be affected by a warmer climate, which in turn will affect behavior of herbivores, emergence of insects, and timing of vertebrate and invertebrate breeding seasons.

These changes in terrestrial and aquatic habitat on the refuge will fundamentally affect fish and wildlife populations and the people that utilize them. National and international legislation may influence the progress of climate warming, but any reversals will be slow. Emerging national, state, and regional policies will provide guidance on how to address the effects of climate change, but such policies are in their early stages and their management implications and ultimate effect on refuge resources and human uses of the refuge are uncertain.

\section{References}

Chapin, F.S. III, M. Sturm, M.C. Serreze, J.P. McFadden, J.R. Key, A.H. Lloyd, A.D. McGuire, T.S. Rupp, A.H. Lynch, J.P. Schimel, J. Beringer, W.L. Chapman, H.E. Epstein, E.S. Euskirchen, L.D. Hinzman, G. Jia, C.-L. Oing, K.D. Tape, C.D.C. Thonpson, D.A. Walker, and J.M. Welker. 2005. Role of land-surface changes in arctic summer warming. Science 310:657-660.

Heglund, P.J., L.B. Saperstein, and E.J. Taylor. 2005. Kanuti National Wildlife Refuge biological program review. Final report. Unpublished USFWS report, Anchorage, AK. 63 pp.

Hinzman, G. Jia, C.-L. Ping, K.D. Tape, C.D.C. Thompson, D.A. Walker, and J.M. Welker. 2005. Role of land-surface changes in arctic summer warming. Science. 310: 657-660.

Hinzman, L.D., N.D. Bettez, W.R. Bolton, F.S. Chapin, M.B. Dyurgerov, C.L. Fastie, B. Griffith, R.D. Hollister, A. Hope, H.P. Huntington, A.M. Jensen, G.J. Jia, T. Jorgenson, D.L. Kane, D.R. Klein, G. Kofinas, A.H. Lynch, A.H. Lloyd, D. McGuire, F.E. Nelson, W.C. Oechel, T.E. Osterkamp, C.H. Racine, V.E. Romanovsky, R.S. Stone, D.A. Stow, M. Sturm, C.E. Tweedie, G.L. Vourlitis, M.D. Walker, D.A. Walker, P.J. Webber, J.M. Welker, K.S. Winker, and K. Yoshikawa. 2005. Evidence and implications of recent climate change in Northern Alaska and other Arctic regions. Climatic Change 72: 251-298.

Hinzman, L.D., W.B. Bolton, K.C. Petrone, J.B. Jones, and P.C. Adams. 2006. Watershed hydrology and chemistry in the Alaskan boreal forest. The central role of permafrost. Pages 269-284 in F.S. Chapin, III, M.W. Oswood, K. Van Cleve, L.A. Viereck, and D.L. Verbyla, eds. Alaska’s Changing Boreal Forest. Oxford University Press, N.Y. 354 pp.

Juday, G.P., V. Barber, P. Duffy, H. Linderholm, S. Rupp, S. Sparrow, E. Vaganov, and J. Yarie. 2005. Forests, land management, and agriculture. Pages 781-862 in C. Symon, L. Arris, and B. Heal, eds. Arctic Climate Impact Assessment. Cambridge University Press, NY. 1042 pp. 
Maier, J.A.K, J.M. Ver Hoef, A. D. McGuire, R. T. Bowyer, L.Saperstein, and H. A. Maier. 2005. Distribution and density of moose in relation to landscape characteristics: effects of scale. Can. J. For. Res.35(9): 2233-2243.

McGuire, A.D. and Chapin III, F.S. 2006. Climate feedbacks in the Alaskan boreal forest. Pages 309322 in F.S. Chapin III, M.W. Oswood, K. Van Cleve, L.A> Viereck, and D.L.Verbyla, eds, Alaska’s Changing Boreal Forest. Oxfod University Paress, New York, N.Y.

Riordan, B., D. Verbyla, and A.D. McGuire. 2006. Shrinking ponds in subarctic Alaska based on 19502002 remotely sensed images. Journal of Geophysical Research, Vol. 111, G04002, doi:10.1029/2005JG000150.

Rupp, T.S. 2008. Projected vegetation and fire regime response to future climate change in Alaska. Preliminary report prepared for U.S. Fish and Wildlife Service National Wildlife Refuge System. 22 pp.

Rupp, T.S., M. Olson, and L. Saperstein 2007. Managing fire on Kanuti National Wildlife Refuge to protect biodiversity under a warming climate scenario. Poster prepared for U.S. Fish and Wildlife Service Climate Change Forum, Anchorage, AK, February 21-23, 2007.

Rupp, T.S., M. Olson, L.G. Adams, B.W. Dale, K. Joly, J. Henkelman, W.B. Collins, A.M. Starfield. 2006. Simulating the influences of various fire regimes on caribou winter habitat. Ecological Applications 16:1730-1743.

Rupp, T.S., A.M. Starfield, F.S. Chapin III, and P. Duffy. 2002. Modeling the impact of black spruce on the fire regime of Alaskan boreal forest. Climatic Change 55:213-233.

Viereck, L.A., C.T. Dyrness, A.R. Batten, and K.J. Wenzlick. 1992. The Alaska vegetation classification. U.S. Forest Service General Technical Report PNW-GTR-286. 278 pp.

Werner, R.A., K.F. Raffa, and B.L. Illman. 2006. Dynamics of phytophagous insects and their pathogens in Alaskan boreal forests. Pages 133-146 in F.S. Chapin III, M.W. Oswood, K. Van Cleve, L.A. Viereck, an dD.L. Verbyla, eds. Alaska's Changing Boreal Forest. Oxford University Press, New York, N.Y. 


\section{Appendix 6. INTERIOR ALASKA ECOREGION—Kenai NWR}

By Ed Berg, Biologist, Kenai NWR

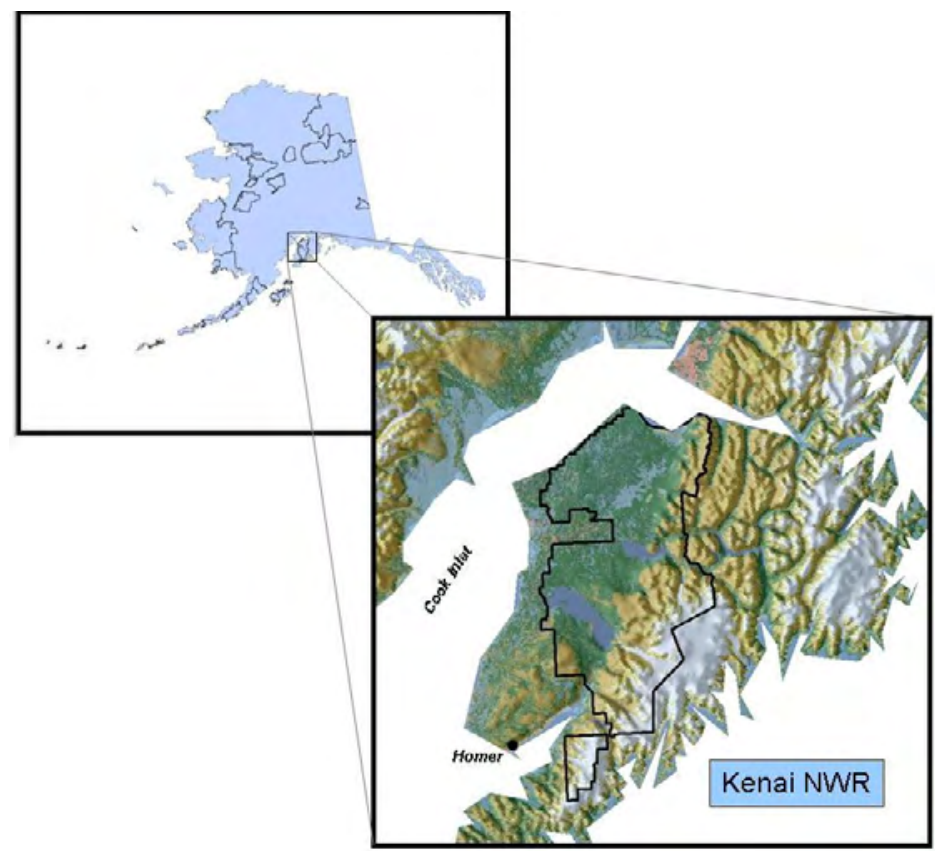

\section{Carbon Cycle in the Boreal Ecoregion}

For ecosystems, one can model the flow of such currencies as energy, water, nitrogen, or carbon. Carbon is especially relevant today because of concerns about increasing $\mathrm{CO}_{2}$ in the atmosphere and ocean. The volume and rate of carbon sequestration and release are likely to be important metrics for monitoring in a world with rapid climate change. These data could be used to evaluate the contribution of habitat management practices (e.g., prescribed fire, silvicultural practices, reforestation) to carbon cycling, to estimate carbon credits in the context of cap-and-trade legislation, or simply to justify to Congress the value of the National Wildlife Refuge System in sequestering carbon. The boreal forest is particularly relevant because it likely represents the largest source of sequestered terrestrial carbon outside of the tropical forests (which are being rapidly consumed). 
One approach to modeling the carbon cycle is with a stock-and-flow model (fig. A6.1). Stockand-flow models can be accurate descriptions of how carbon moves through a system if the stocks and flows are accurately known. In their simplest form these models are not mechanical models, but are merely descriptive and predictive. Each linkage between stocks (i.e., each flow), however, is the result of causal processes and ideally can be causally modeled. General circulation models (GCM's) of the Earth's climate employ spatial compartments or cells spanning many cubic kilometers and use physical laws to mechanically model the flows of a currents of air, water and energy from one compartment to another.

Stock-and-flow modeling can be done at every scale. Canada has a large staff of carbon budget modelers at the Pacific Forestry Centre in Victoria modeling the national carbon budget from peatlands through forests through industrial carbon flows, in preparation for Canada's participation in a Kyotostyle international carbon ceiling agreement. On the other hand, carbon budget modeling can be done on the scale of individual roots or leaves in plants. In theory, such fine-scale models can then be amalgamated and scaled up to the whole plant, and then to the crop or forest, and so on.

\section{Stock-and-Flow Model of the Kenai Peninsula Carbon Budget}

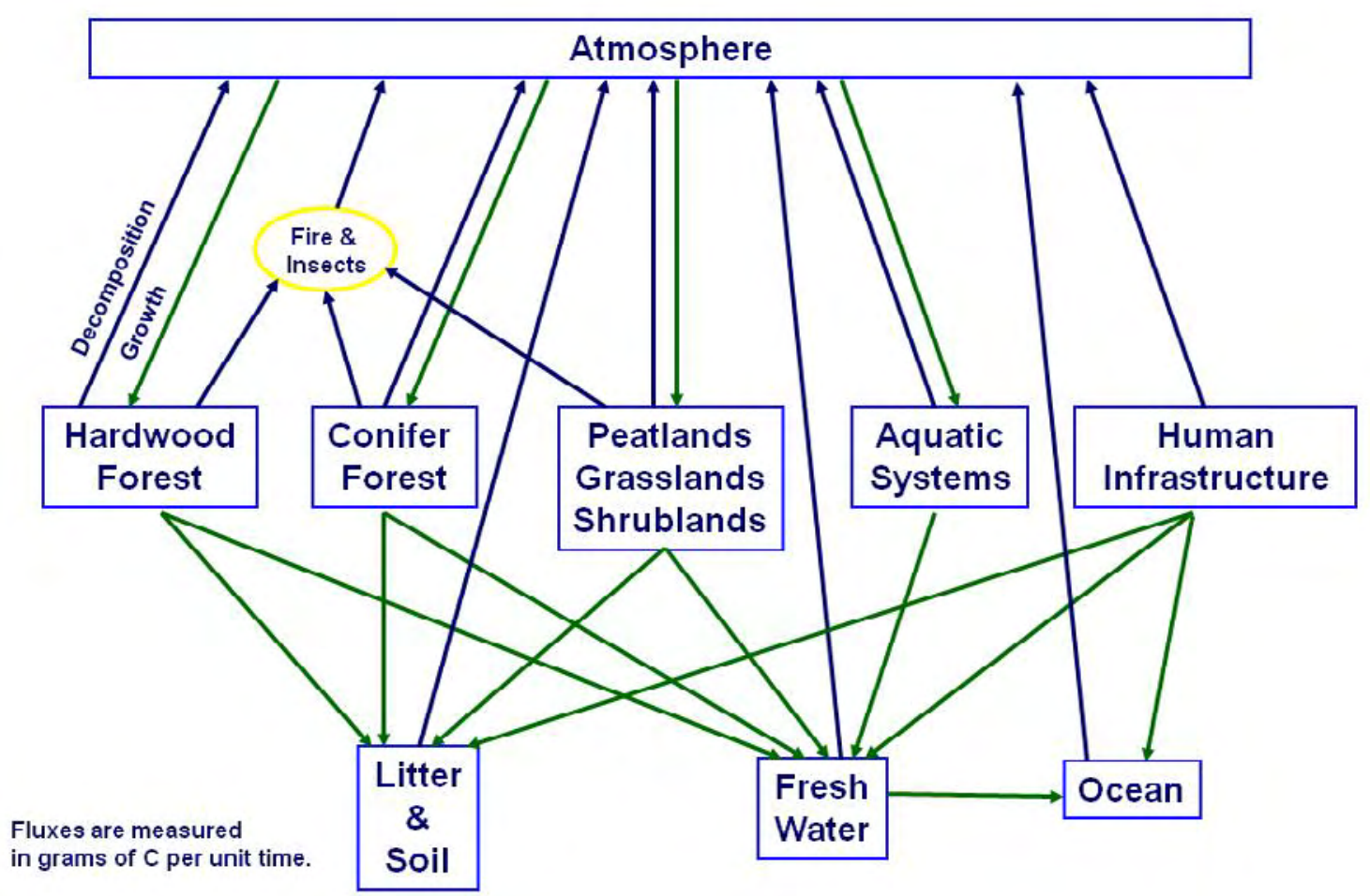

Figure A6.1. Carbon cycle of boreal areas. 
Let's consider how carbon flow through the boreal forest system might be modeled, starting with primary succession on newly exposed landscape, as with glacier retreat or following an extremely severe mineral soil exposing fire. The accumulation of above-ground carbon could be modeled from existing permanent plot studies that have tracked successional vegetation over many years. The accumulation of below-ground carbon is much more poorly understood and needs research. A recent study, for example, generated the surprising result that old growth forests continue to add underground biomass through root proliferation, even after the above-ground biomass has reached a more or less stable plateau where incremental tree growth is offset by tree death and decomposition. New technologies with minirhizotrons and root monitoring scanners have been developed to study root growth in soil. Radioactive isotopes, like ${ }^{14} \mathrm{C}$, also are valuable tools for tracking carbon exchange between roots and soil. Such technologies should greatly facilitate the modeling of carbon sequestration in soil as forests go through various stages of succession, just as traditional forestry metrics track aboveground biomass and carbon, such as those of the USDA Forest Service's Forest Inventory and Analysis (FIA) program and its FORCARB2 carbon budget simulation model.

A next step in modeling forest carbon flow would be to examine the effect of disturbance processes like fire, bark beetles (e.g., Dendroctnus rufipennis, Ips spp.), and wind throw. A forest fire obviously generates a pulse of $\mathrm{CO}_{2}$ to the atmosphere, which offers an argument that forest fires should in general be suppressed to combat global warming. On the other hand, some studies have shown that this new airborne carbon may be recouped fairly quickly through rapid early successional forest growth. The residence time of $\mathrm{CO}_{2}$ in the atmosphere is estimated to be about 200 years, before the $\mathrm{CO}_{2}$ is taken up by the oceans or plants. If a burned forest has recouped its carbon in 50 years, it is reasonable to view the fire-generated atmospheric carbon as a transient contribution. Careful modeling is needed here to examine this carbon recapture process under a variety real world conditions and forest compositions, especially as regards fire suppression and climate change amelioration policies.

Bark beetles and other relatively slow-acting agents of tree mortality also feed $\mathrm{CO}_{2}$ to the atmosphere, but do so very slowly through decomposition. In some cases, this carbon loss can be offset fairly quickly by growth release of surviving understory trees and recruitment of shrubs and hardwoods such as alder (Alnus spp.). A study on the Kenai NWR, for example, estimated that spruce biomass killed in the 1970s bark beetle outbreak was fully recouped by the mid-1990s through release of understory spruce survivors. This result cannot however be generalized to the much more extensive and severe outbreak of the 1990s because many stands lacked a cohort of understory trees which could be released. In this case, carbon is being recaptured primarily through proliferation of rapidly growing hardwoods.

In building a stock-and-flow carbon model, it is necessary to measure the stocks so that the model can make forecasts about future carbon stocks at an ecosystem level. Stocks of forest carbon are the easiest to estimate because forestry methods for estimating timber volume are well developed and can be extended to total above-ground carbon. In much of Alaska, however, the vast majority of carbon is tied up in peat and permafrost soils. Peat volume can be measured with a ground-penetrating radar (GPR) unit pulled by snow machine in a series of traverses across a peatland, and hand cores samples can be taken to measure peat carbon content.

We know for example that there are vast stocks of carbon tied up in peatlands. Careful measurement of $\mathrm{CO}_{2}$ flows at experimental sites suggests that flows are positive into peatlands in cool years (through photosynthesis and plant growth) and are negative in warm years (through increased respiration and decomposition). In assessing the carbon budget of peatlands, one also must consider methane flows, which are traditionally difficult to measure, and flows of dissolved organic carbon in the soil water. 
The carbon stocks in permafrost soils are more difficult to assess, requiring vehicle-mounted core drills to take deep soil samples. To see why this might be worth doing, consider the following numbers: for the permafrost areas of Russia the taiga and tundra vegetation is estimated to contain $20 \mathrm{Gt}$ (gigatons) of carbon, the organic component of the 1-meter active layer contains $150 \mathrm{Gt}$, and the upper 100 meters of permafrost contains $9000 \mathrm{Gt}$ of carbon. A significant pool of carbon also is tied up as methane hydrate in permafrost rocks (Zamolodchikov and others, 2004).

The carbon fluxes in permafrost soils are being intensely studied in many Arctic sites. Methane released from thawing permafrost can enter the atmosphere directly (as a very potent greenhouse gas) or it can be metabolized by methanotrophic bacteria and then released as $\mathrm{CO}_{2}$. New technologies such as eddy covariance towers using Fast Greenhouse Gas Analyzers (FGGA) can simultaneously measure fluxes of $\mathrm{CO}_{2}$, methane and water vapor over a footprint of several thousand square meters. As these studies progress, they will provide estimates of flux rates that carbon budget modelers can generalize to landscape scales.

Anthropogenic effects are an important part of carbon budget modeling. The large GCM's must make various assumptions about human population growth, economic activity and expected climate change legislation. A carbon budget for a limited land area, such as a Federal land unit, must include an atmospheric compartment that exchanges fluxes with the atmosphere of the whole Earth, and is obviously dependent on projected future forecasts of greenhouse gas concentrations in the greater atmosphere. More locally, however, a Federal land unit could monitor and model is own greenhouse gas emissions and biomass changes caused by landscape manipulations (e.g., prescribed burning, harvest, planting, etc.), as well as by natural processes such as wildfire, insect outbreaks and plant succession. This may be important if Federal land units are charged by Congress to have zero net greenhouse gas emissions in the future. Kenai Fjords National Park, for example, voluntarily purchases carbon credits to achieve net zero greenhouse gas emissions.

It is interesting to consider possible ways that Federal land units, such as National Wildlife Refuges, National Parks, and National Forests, might participate in carbon budget modeling. Perhaps the most important fact is that these units are fixed geographic places, which can be the foci of on-going research activities. Researchers attached to universities and non-land-based government agencies shift from place to place according to their research interests and needs. Managers and researchers on Federal land units, on the contrary, want information about their specific units. Over a period of years, they acquire a bank of knowledge about their unit, which can be used for management decisions, as well being available for visiting researchers and the general public. Federal land units are typically larger, more permanent, and much better staffed and funded than similar state or local land units, so Federal units are better situated to be foci of research activities in general, and carbon budget modeling projects specifically.

Place-based institutions, such as Federal land units, are likewise best suited to deal with the time factor in carbon budget modeling. Effective modeling requires monitoring of current fluxes, such as forest biomass loss and accumulation, greenhouse gases from both natural and anthropogenic sources, and aquatic carbon fluxes. The estimates of long-term flux rates used to calibrate or parameterize the model are of equal importance in modeling. Models of the future typically consist of three parts: a set of equations (either deterministic or statistical), the parameters of the equations, and a set of initial conditions. The values of the initial conditions are plugged into the equations in order to generate predicted values of future conditions. Field measurements and monitoring programs can provide the initial conditions at the present moment, but paleoecological studies are usually necessary to estimate the parameters for the equations that will predict how the present values will change through time. 
On the Kenai National Wildlife Refuge, we have used paleoecological methods to estimate fire frequency in forest types, such as lowland black spruce (Picea mariana), white/Lutz spruce (Picea glauca/P. x lutzii) forests, and mixed white spruce and hardwood forests, on time scales ranging from 300 to 13,000 years, based on dendrochronology, soil charcoal, and lake sediment charcoal. We have estimates of rates of wetland invasion by forest and shrubs, measured in detail since 1951 on aerial photography, and more generally over the last 19,000 years based on peat core analysis. Dendrochronology also has provided estimates of spruce bark beetle outbreak frequency over the last 250 years. Comparative aerial photograph analysis has allowed us to estimate the general rise of treeline to be about 1 meter per year since the early 1950s. It would take many decades or centuries of direct monitoring of field plots to generate the estimates of rates that we have obtained with paleoecological methods in a relatively small number of years.

There are a few more pieces that should ideally be put in place before the KENWR undertakes construction of a carbon budget model. Peatlands are still a large unknown. We need a ground penetrating radar survey of a statistically valid sample of peatlands in order to estimate the stock of carbon sequestered in peatlands. A graduate student from the Alaska Pacific University is currently measuring monthly $\mathrm{CO}_{2}$ flux with a portable $1-\mathrm{m}^{3}$ closed chamber in a peatland along several steps of a moisture gradient. A Fast Greenhouse Gas Analyzer on an eddy covariance tower could be used to measure both $\mathrm{CO}_{2}$ and methane over a footprint of several thousand square meters around this study site; this would allow the results to be generalized more confidently to other peatlands in the area. In addition, FIA data could be used to estimate stocks of above-ground forest carbon, but we need studies of upland soil carbon stocks and fluxes. This is a complete unknown on Kenai NWR, although values could be estimated from the literature. Lastly, most of the key determinants of the carbon budget are climate driven, so it is necessary to have good weather data for the model. The proposed NOAA Climate Reference Network (CRN) station will be valuable, especially for accurate measurements of winter precipitation, but more RAWS-type stations would useful.

Carbon budget modeling should not be viewed as a one-shot endeavor, to be done by a graduate student or a contractor, but rather as an integrating platform for a long-term monitoring program. The model should be revised periodically as its predictions are tested in real time against data provided by monitoring. A good model should reveal data gaps in the monitoring program, and should provide an objective assessment of the relative carbon-value of factors being monitored.

\section{Reference}

Zamolodchikov, D.G., Karelin, D.G., and Chestnykh, O.V. 2004. Measurements of carbon balance in permafrost ecosystems: advances and problems. Doklady Biological Sciences 397:333-335. 
This page left intentionally blank 


\section{Appendix 7. INTERIOR ALASKA ECOREGION-Koyukuk, Nowitna, and Northern Innoko NWRs}

By Brad Scotton, Supervisory Biologist, Koyukuk-Northern Nowitna NWR Complex

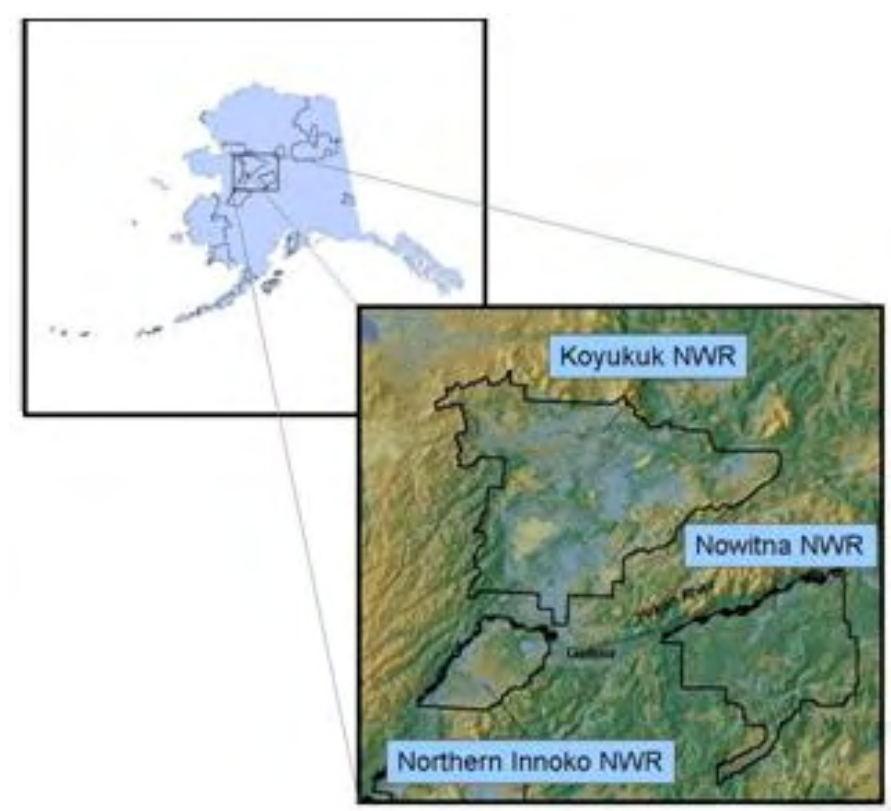

\section{Geographic Context}

This refuge complex is part of arguably the largest intact ecoregion of the world (boreal). Found in northern areas, they are the repository for vast quantities of stored carbon and trapped methane (in the permafrost). Maintaining the connections is important to not just this region, but probably the world.

\section{Abiotic Components}

The sun, wind, rain, run-off, and ice scouring are all non-biological components that will affect this dynamic system. These components are essentially drivers of ecosystem processes (fig. A7.1).

\section{Biotic Components}

The life in this system is largely healthy and intact. The entire species complement is currently present and accounted for. Successful understanding and prediction of change caused by a shifting climate can only be accomplished by studying the biological connections in concert with the abiotic components.

\section{Ecosystem Drivers}

Regional climate (large red arrows, fig. A7.1) affects the overall system at the most fundamental level. Solar and moisture inputs during a short growing season drive the potential for primary productivity of the terrestrial and aquatic plants that sustain the rest of the components of the system. 


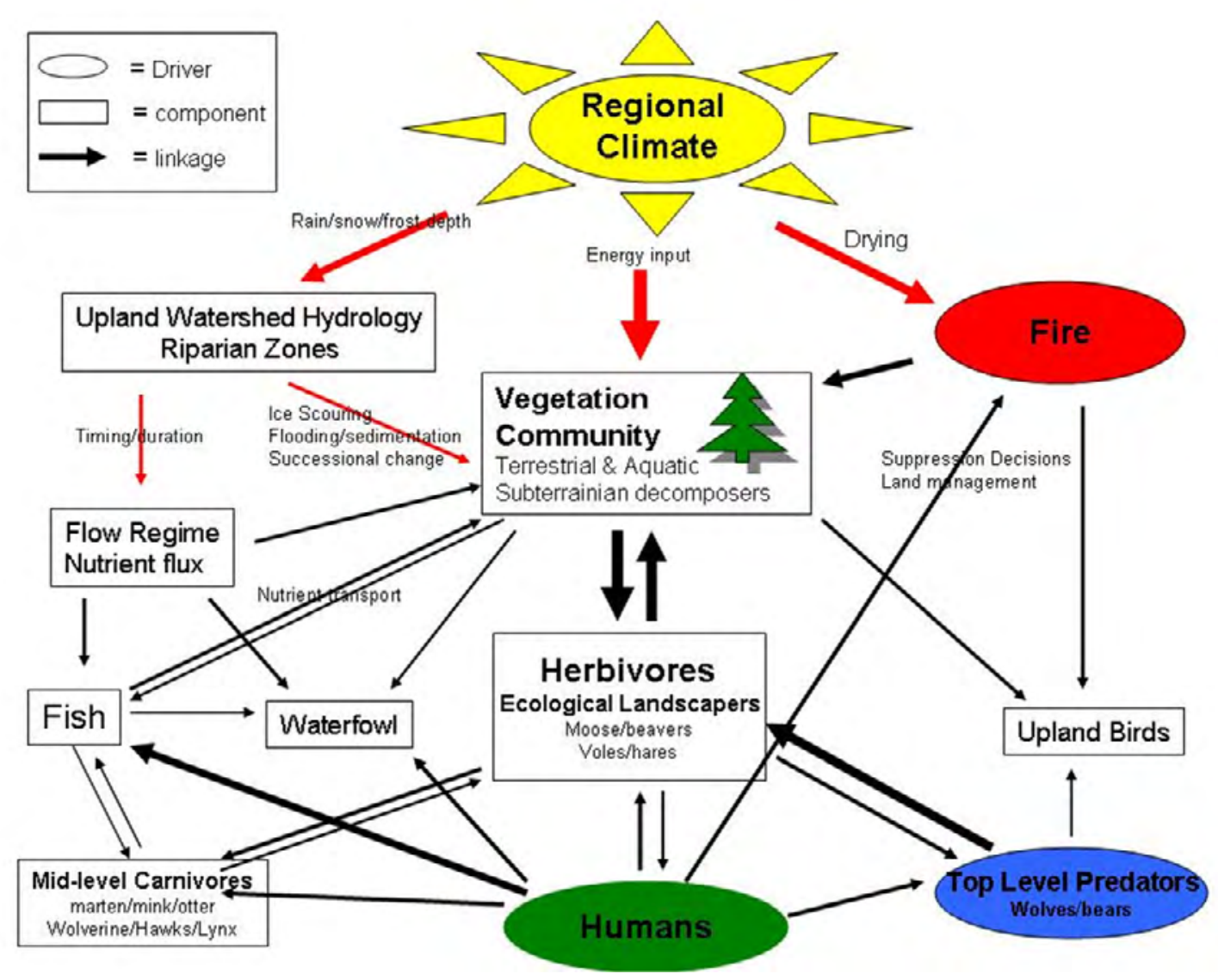

Figure A7.1. Conceptual model describing Koyukuk, Nowitna, and Northern Innoko NWRs. Thickness of arrows, indicates a relative weighting of importance of linkages or connections between components. Red arrows indicate linkages likely to be directly influenced by global climate change.

Important abiotic drivers that reset succession of habitat include fire, and ice-scouring and erosion in the riparian areas. Climate directly affects the magnitude and frequency of these disturbances. Precipitation and freeze depth control flooding and nutrient movement within our productive riparian zones.

Ecological landscapers such as moose (Alces alces), beavers (Castor canadensis), voles (large arrows) interact dramatically with, and actually shape their environment. The abundance or absence of these players alters the dynamics of the host of other creatures that use them for food. Top-level predators directly influence the abundance of these animals and thus, can alter the landscape as a driver. Interior Alaska would look vastly different without them.

Fish, both resident and anadromous, transport significant amounts of nutrients throughout the system. Notably, salmon (Onchorynchus spp., affected largely by commercial and subsistence harvest) bring ocean-derived nutrients into the tributaries of the refuge complex. 
Humans are intimately intertwined within the system. Changes in human behaviors, harvest rates, habitat manipulation, and decision making with regards to fire suppression can all change the dynamics of the system. Understanding the magnitude of our influence is important to 'management' of the system.

\section{Potential Effects of Contemporary Climate Change}

All ecosystems are vulnerable to perturbations, but are also resilient and adaptable. The most obvious 'threat' to the boreal ecosystem is the potential for rapid loss of permafrost. That factor alone would dramatically affect the system from the bottom up (microbial activity, primary productivity, plant species composition, etc.). The release of vast stores of methane from frozen ground could have dramatic affects on the climate. Warming will likely alter hydrologic cycles as well, thus changing nutrient flow and species composition. While we are fortunate that threats common elsewhere in the United States (e.g., fragmentation, contaminants and domestic grazing) are less common here, we will likely be at the forefront of change related to our changing climate. 
This page left intentionally blank 


\title{
Appendix 8. INTERIOR ALASKA ECOREGION-Selawik NWR
}

\author{
By Tina Moran, Supervisory Biologist, Selawik NWR
}

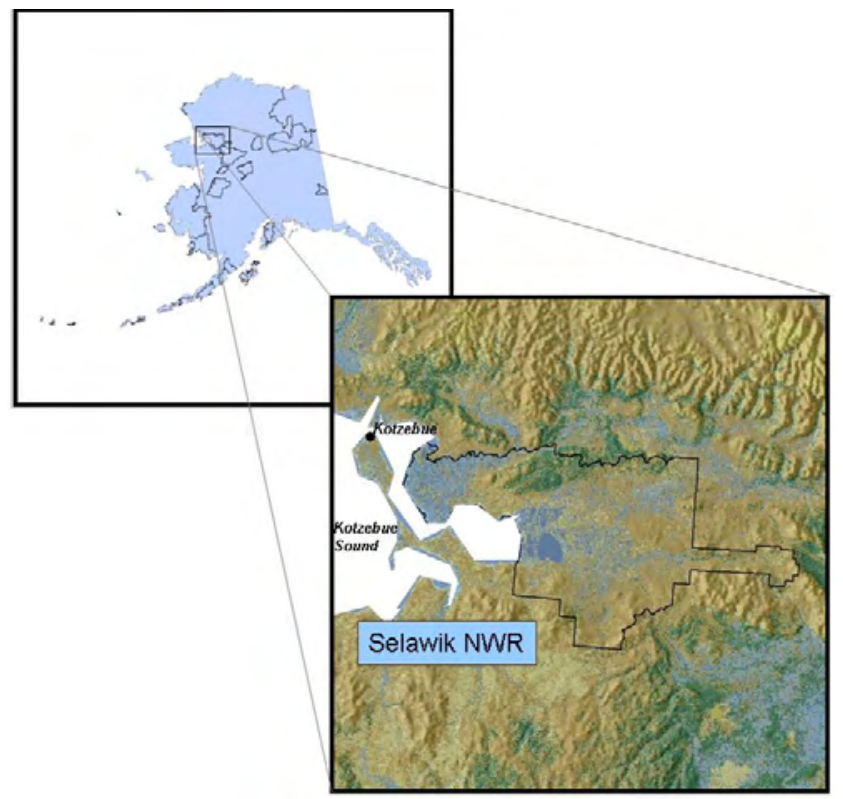

\section{Geographic Context}

Bisected by the Arctic Circle, Selawik NWR, which at 870,000 ha, is about the size of Connecticut, lies in the northwest corner of Alaska. It extends from just north of the Seward Peninsula, on the edge of the Chukchi Sea and the Kotzebue Sound, inland for more than $150 \mathrm{~km}$. Sandwiched between the NPS units of the Bering Land Bridge on its west, and Noatak National Preserve and Kobuk Valley National Park north of it, the refuge runs along the Selawik River and south of the Brooks Range. Selawik NWR contains a diversity of habitats across elevational gradients, from lowlands and river deltas to arctic tundra to vegetated sand dunes to alpine and subalpine mountain communities. Given that the refuge is located at approximately the same latitude as the Bering Land Bridge that once connected North America and Asia, the refuge's flora and fauna reflect a signature of both continents' biotas.

\section{Climate}

On average, Kotzebue receives the lowest annual precipitation (255 mm/yr) among weather stations in west-central Alaska, less than one-half as much received at St. Mary's, which receives the highest annual precipitation (532 mm/yr) in the region (Shulski and Wendler, 2007). Kotzebue experiences an average annual snowfall of $124 \mathrm{~cm}$, and average wind speeds of $5 \mathrm{~m} / \mathrm{s}$, with a northwestern prevailing wind direction. Average low temperature at Kotzebue in January is $-23^{\circ} \mathrm{C}$, whereas average high temperature in July is $15^{\circ} \mathrm{C}$; annually, temperature averages $-6^{\circ} \mathrm{C}$ (Shulski and Wendler, 2007). Across the refuge, low temperatures decrease as one moves inland or up in elevation; for example, average low temperatures in January range from $-19^{\circ} \mathrm{C}$ to $-26^{\circ} \mathrm{C}$, and can reach below 
$-57^{\circ} \mathrm{C}$. High temperatures also increase as one moves inland, and can exceed $32^{\circ} \mathrm{C}$ in inland portions of the refuge. Although some precipitation typically is received in all months, the greatest amount is received in summer and early fall months (Shulski and Wendler, 2007). Snow typically persists until May. The refuge experiences near-continuous sunlight for several months in the summer.

\section{Abiotic Components}

Near the headwaters of the Selawik River, two locations in the refuge have hot springs, which have been used by residents in the region for at least a century. The uppermost $250 \mathrm{~km}$ of the Selawik River have been congressionally designated as a Wild River. Vegetated sand dunes in the Waring Mountains have persisted since the Pleistocene; these and other habitats are protected within the Selawik Wilderness area in the northeastern portion of the refuge. The refuge is dominated by tundra wetlands and more than 24,000 lakes.

\section{Biotic Components}

The refuge was established to conserve caribou (Rangifer tarandus), waterfowl, shorebirds and other migratory birds, salmon (Onchorynchus spp.), and sheefish (Stenodus leucichthys). More than 180 bird species have been recorded in the refuge, including several species from Eurasia that do not migrate through any of the four North American flyways. At least ten bird species, including northern hawk owls (Surnia ulula), willow ptarmigan (Lagopus lagopus), and hoary redpolls (Carduelis hornemanni), are year-round residents of the refuge. Sheefish, large predatory whitefish that occur only in arctic and subarctic drainages of North America and Siberia, are an important species for subsistence and sport harvest. The species, which can weigh more than $23 \mathrm{~kg}$, is the source of the refuge's name, derived from the Inupiat word "siilvik" (place of sheefish).

More than 30 mammal species occur on Selawik NWR. The Western Arctic Caribou Herd, which is the largest herd in Alaska, migrates through the refuge twice per year in spring and fall and groups of more than 27,000 animals have been observed in the refuge. Muskoxen (Ovibos moschatus) are the other ungulate on the refuge, though they occur at much lower densities than do moose (Alces alces). Numerous carnivores inhabit the refuge, from black (Ursus americanus) and grizzly bears (Ursus arctos), to wolves (Canis lupus), wolverines (Gulo gulo), red foxes (Vulpes vulpes), American martens (Martes americana), and lynx (Lynx canadensis). Beavers (Castor canadensis), muskrats (Ondatra zibethicus), moose (Alces alces), mink (Mustela vison), short-tailed (Mustela erminea) and least weasels (Mustela nivalis), and river otters (Lontra canadensis) are associated with rivers, lakes, and streams. Small mammals include shrews, voles, lemmings, arctic ground squirrels, and snowshoe hares.

Spruce (Picea spp.) and willows (Salix spp.) line the river corridors, and provide important habitat elements for numerous bird species, and fishes. Other community types include spruce forests, paper birch (Betula papyrifera) and lichen communities, riparian zones, grass and sedge (Carex spp.) meadows, dwarf birch (Betula nana) and open tundra, aspen (Populus tremuloides) groves, and wetland edges.

\section{Ecosystem Drivers}

Climate is a major driver and has a variety of influences on the natural resources of the Selawik NWR (fig. A8.1). The Refuge encompasses a diverse range of habitats from coastal, wetland, riverine, boreal forest, and mountains. The Refuge includes the entire Selawik River Drainage with the Waring Mountains and Kobuk River defining the northern border, the Nulato Hills and Purcell Mountains 
defining the southern and eastern borders, and Selawik Lake and Hotham Inlet defining the Eastern border. Permafrost underlies most Refuge lands. This model attempts to illustrate the affects of climate on four mechanisms influencing the Refuge's natural resources, i.e., landform change, temperature periodicity, dynamics of water/ice in soil, and phenology.

Landform change includes changes in ground structure including erosion, sloughing, and collapsing tundra. These changes can occur if a warming event (long-term or short-term) allows permafrost to thaw, which in turn can affect rates of soil erosion. Effects of soil erosion may include sloughing into rivers, beach erosion and terrestrial slumping or sinkholes. In turn, this erosion can affect water quality (via siltation rates), and habitat quality of streams for fishery and terrestrial systems via altered water-table levels. The upper Selawik River thermokarst is an example of an event causing land area along the river to collapse resulting in a continuing spillage of silt into the river. This event is causing changes in the river system including flow and clarity. These changes may affect a major sheefish spawning area that occurs only a few miles downriver of the event.

Climate can affect the frequency of biologically relevant events, including freeze-thaw switches, extreme cold, droughts, rain-on-snow events, etc. Short-term warming trends in mid-winter can cause periodic rain and/or melting. Freezing temperatures then return, causing a hard crust of snow on the tundra, increasing the difficulty for herbivores to access vegetation.

The amount of snow and rain also can affect water quality and availability on the Refuge. Permafrost thawing also may influence drying or filling of lakes and ponds. Changes in lake systems can affect changes in soil properties and allow accelerated or decelerated rates of successional changes in vegetation communities. Diminishing water levels in rivers and lakes may also affect the wildlife that depends on them. Shallower areas may attract dabbling ducks and shorebirds or use by other wildlife, while displacing others. Higher water temperatures in rivers caused by increasing temperatures and/or low water may affect also fisheries resources on the Refuge.

Climate may affect the timing of animal and fish migrations, including Neotropical landbirds, shorebirds, waterfowl, caribou, and anadromous species. Temperature changes can affect migration by changing the availability of food and water resources, cover, etc. Temperature can possibly trigger earlier or later migrations of species immigrating to or emigrating from the Refuge. Temperature changes can also affect disease and pest dynamics on the refuge.

Fire also serves as a driver on the refuge, but is also influenced by climate. Overall, the model (fig. A8.1) attempts to focus on how climate can affect the Refuge's natural resources and how the dynamics can change as various factors are affected.

\section{Potential Effects of Contemporary Climate Change}

Contemporary climate change is likely to increase extent and frequency of wildfires in the interior, more-boreal portion of the refuge. Permafrost will likely continue to become thinner and be lost altogether, in some locations. Altered seasonal cover of sea ice is expected to have implications for local climate as well as for rates of coastal erosion and saltwater intrusion into estuaries. Geographic ranges of resident and migratory species will continue to shift, with the latter experiencing not only spatial shifts, but also temporal shifts that will affect community structuring and effect phenological mismatches.

\section{References}

Shulski, M. and G. Wendler. 2007. The Climate of Alaska. University of Alaska Press, Fairbanks, 216 p. 


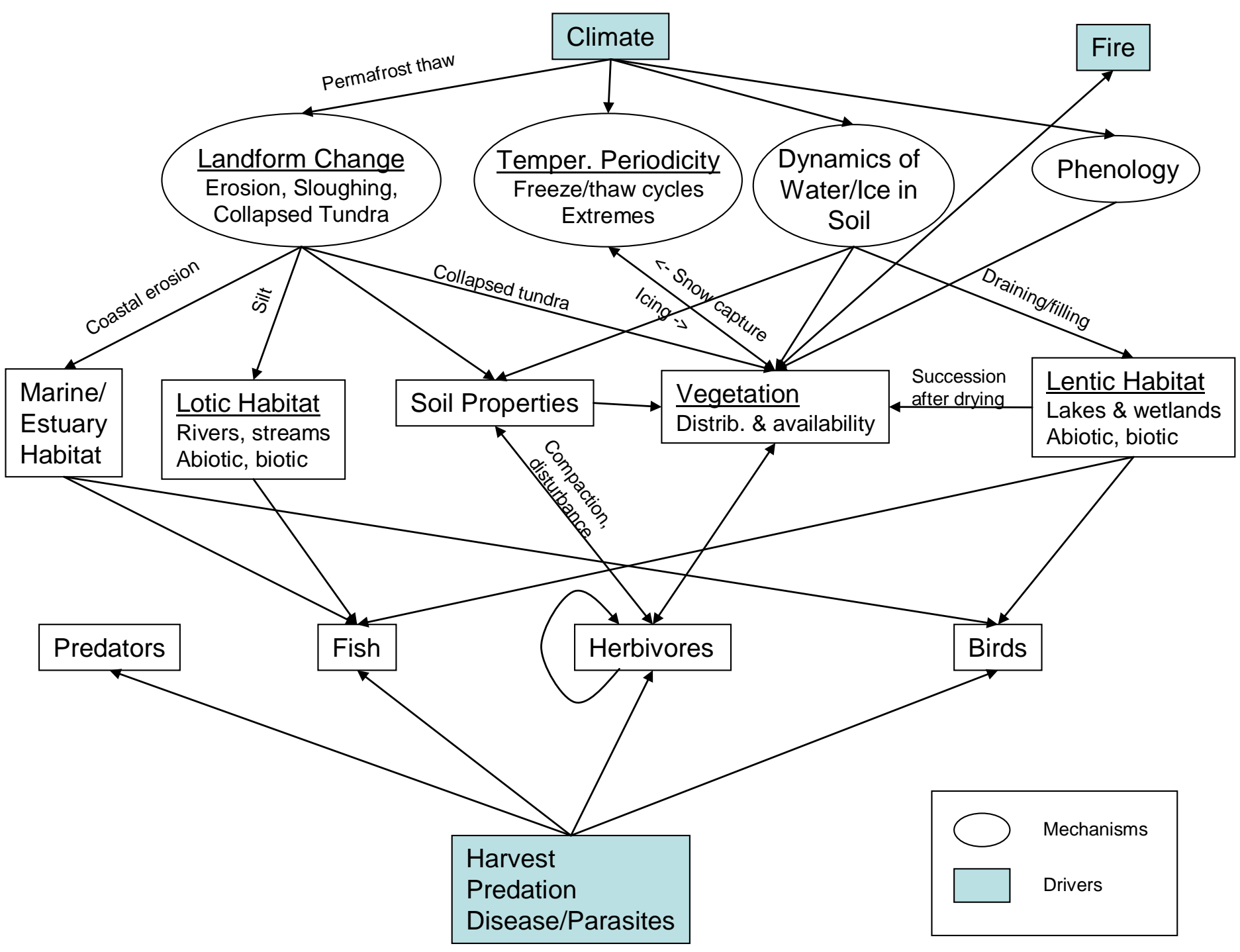

Figure A8.1. Conceptual model of Selawik NWR. 


\section{Appendix 9. INTERIOR ALASKA ECOREGION-Tetlin NWR}

By Bud Johnson, Supervisory Biologist, Tetlin NWR

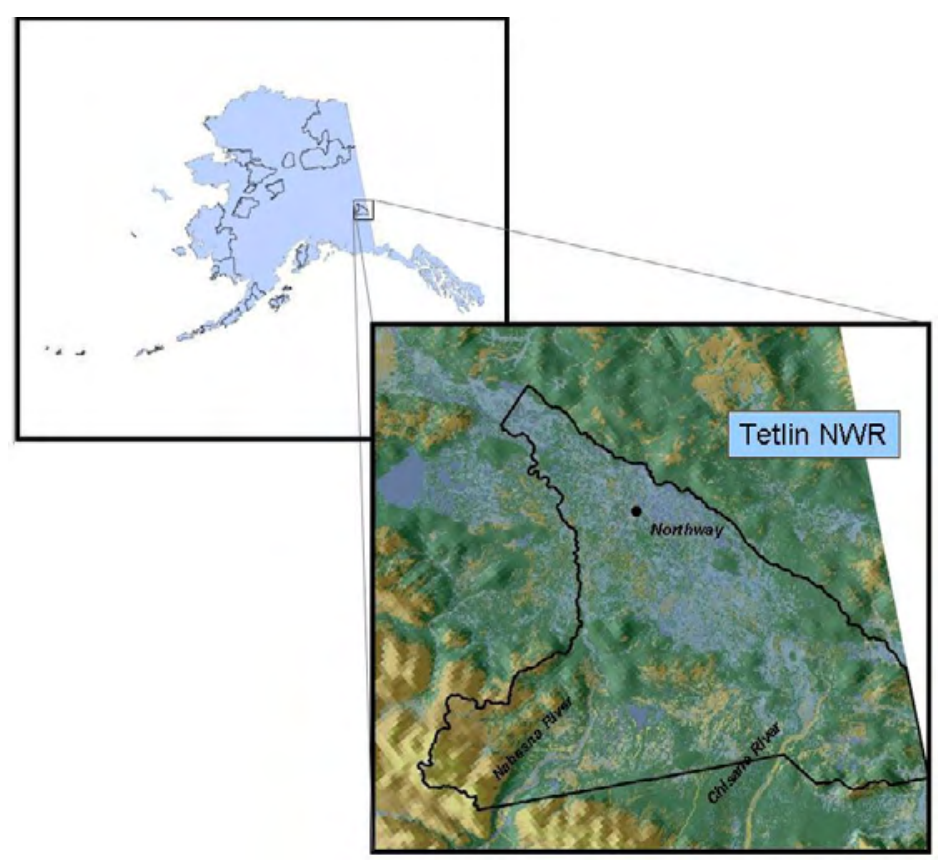

\section{Geographic Context}

Tetlin NWR lies within the intermontane boreal ecoregion and comprises a large portion of the Upper Tanana Valley watershed. Our goal in developing a conceptual model was to identify the primary drivers, components, stressors, and processes that influence the habitats found within the Refuge and watershed. Sources for supporting information include Kasischke and Stocks (2000), Krebs and others (2001), U.S. Fish and Wildlife Service (2004), and Chapin and others (2006).

\section{Climate}

The continental subarctic climate of Tetlin Refuge is characterized by large seasonal temperature extremes. More than one-half of the average annual precipitation occurs during the summer. Weather patterns throughout June and July are conducive to the development of thunderstorms, which produce numerous lightning ground strikes - the primary natural cause of fires within and around the Refuge. Snow can occur anytime, but the Refuge is usually snow free from mid-June to mid-August. Snow cover is usually complete by mid-October and lasts through the end of April. Temperature drives the freeze-thaw cycle, which in turn influences fire regime, flow regime/flooding, permafrost degradation, and growing season. Precipitation influences hydrology, fire regime, and processes, such as erosion and sedimentation. 


\section{Abiotic Components}

Both glacial and non-glacial streams run through Tetlin Refuge. The Nabesna and Chisana Rivers originate from glaciers in the Wrangell Mountains within the Wrangell-St. Elias National Park and meander north to their confluence just north of Northway Village, where they form the Tanana River.

In addition to glacial and non-glacial rivers and streams, the Refuge contains numerous lakes, ponds, and wetlands. The northern portion of the Refuge is almost entirely occupied by highly productive wetland complexes of ponds, marshes, and streams. Smaller wetlands can be found near the eastern boundary along Scottie Creek and Desper Creek, Mirror Creek, and Wellesley Creek. On the southern plateau, there are also small concentrations of ponds around Jatahmund Lake and Pickerel Lake. The soils of Tetlin Refuge are dominated by fine-grained silts and clays mixed with pockets of sand, gravel, and organic deposits.

\section{Biotic Components}

Vegetation is a key component of habitat that provides the energetic foundation of the terrestrial ecosystem via primary production and is essential for carbon sequestration. A generalized food web for the Refuge highlights the importance of the primary producers to fauna. The Tetlin Refuge supports a diverse array of vegetation communities that are characteristic of the northern boreal forest ecosystem in Alaska, ranging from closed black spruce (Picea mariana) forests to alpine tundra.

Most of the communities are interspersed with wetlands. The southern half of the Refuge is predominantly forested upland, while the northern half mostly consists of a low floodplain containing a mosaic of lowland forests, shrublands, muskeg, and associated wetland habitats.

The area is part of the circumpolar northern coniferous forest in North America, which extends south from the Brooks Range into Canada. Within Tetlin Refuge, forest cover types dominate at elevations below treeline (ca. 3,200 feet; 975 meters). Open (25-60\% tree cover) stands of black spruce are particularly common in low-relief wet terrain and are often indicative of the presence of permafrost. White spruce (Picea glauca), occasionally growing with paper birch (Betula papyrifera)and aspen (Populus tremuloides), can be found in better drained and warmer sites. Vegetation is altered over time as the physical drivers change and by anthropogenic stressors. For example, paper birch, willow (Salix spp.), and aspen may dominate following fire on southern exposures.

Fauna are important ecosystem components that are affected directly by ecological drivers and indirectly by the effect of drivers on other habitat components (i.e., water bodies and vegetation). In turn, fauna can directly affect other components. Within the faunal component beaver and forest pests have been placed in ovals to acknowledge their capacity to function as ecosystem drivers. In addition, forest pests are shaded in red to indicate their sensitivity to climate change.

Beaver (Castor canadensis) can easily alter the structure and dynamics of aquatic ecosystems. Through dam building and feeding activities, beaver can alter hydrology, channel geomorphology, biogeochemical pathways, and community productivity. Similarly, forest pests have the capacity to make landscape scale changes to vegetation communities. Bark beetles can be one of the most destructive pests in Alaska, particularly spruce (Dendroctonus rufipennis) and engraver beetles (Ips spp.). Large outbreaks of spruce beetles on the Kenai Peninsula and elsewhere in south-central Alaska and western Canada have increased concerns about possible large-scale damage in Alaska's interior region. 


\section{Ecosystem Drivers}

We initially generated a long list of ecosystem drivers but eventually settled on four key physical drivers: (1) Fire Regime, (2) Climate, (3) Hydrology, and (4) Geology (fig. A9.1). Of these, local climate was identified as the primary driver and all drivers are connected by their role in the water cycle. The water cycle provides feedback among the drivers and thus the arrows (processes) move in both directions.

Fire Regime.-Periodic fire is one of the primary natural forces that drives plant succession. The vegetative mosaic on the Refuge is largely an expression of the Upper Tanana Valley fire regime (i.e., the characteristic pattern of fires including variations in ignition, intensity, behavior, size, recurrence interval, and ecological effects). Fire regime is shaped by climate, hydrology, and geology; but can influence these other drivers as well. For example, the release of $\mathrm{CO}_{2}$ into the atmosphere can influence climate; and post-fire increases in run-off and active layer depth directly affect hydrology.

Hydrology.-Our model's hydrology driver focuses primarily on the movement of ground and surface water across the landscape (fig. A9.1). Flooding is a natural component of this process that alters vegetation patterns, water quality and drainage patterns over large portions of the Refuge; and affects habitat availability and quality for many fish and wildlife species. Flooding often occurs after ice breakup during spring runoff in the non-glacial streams. Ice jams commonly block rivers already swollen by snowmelt runoff. This annual flooding is largely responsible for recharging wetlands and redistributing nutrients throughout the Refuge.

Discharge from Tetlin's rivers is regulated primarily by the rate of glacial melt. Glacial discharge fluctuates diurnally as well as seasonally, and is at its highest during periods of hot, dry weather - usually from mid to late July. The non-glacial streams are smaller and originate in the foothills that lie both north and south of the Refuge. In general, non-glacial discharge increases rapidly in May with the melting snowpack, peaks by early June, and then returns to a medium to low flow. Sharp spikes in the discharge may be expected during the summer in response to thunderstorms.

Geology.-Formed by glacial processes, the large and flat Northway basin of the Upper Tanana Valley is filled with sediments deposited in moraines and outwash plains. These sediments, comprised of silt, sand, and gravel were carried directly by huge glaciers from the massive ice cap covering the Wrangell Mountains, or indirectly by their meltwater streams and water bodies. The resulting landscape is dominated by lakes, ponds, wetlands, streams and the braided, glacier-fed Nabesna and Chisana Rivers. Several small receding remnant glaciers remain in the southwest corner of the Refuge on high peaks at the head of the Cheslina River drainage. Aeolian deposits of sand and silt (loess) carried by winds off the glaciers formed dunes along much of the Alaska Highway corridor in roughly parallel waves. Today these dunes are mostly vegetated.

The soils of Tetlin Refuge are dominated by fine-grained silts and clays mixed with pockets of sand, gravel and organic deposits. Drainage through these soils is generally poor, resulting in discontinuous layers of permafrost at or near the surface. On south and west facing slopes, and along the fringes of larger water bodies, greater soil warmth and/or better drainage often reduces or eliminates surface permafrost. Permafrost is sensitive to climate change because frozen soils are just slightly below freezing. Increased infiltration of water into the ground resulting from the degradation of permafrost could drain lakes and coupled with increased evapotranspiration, led to drier surface conditions. 


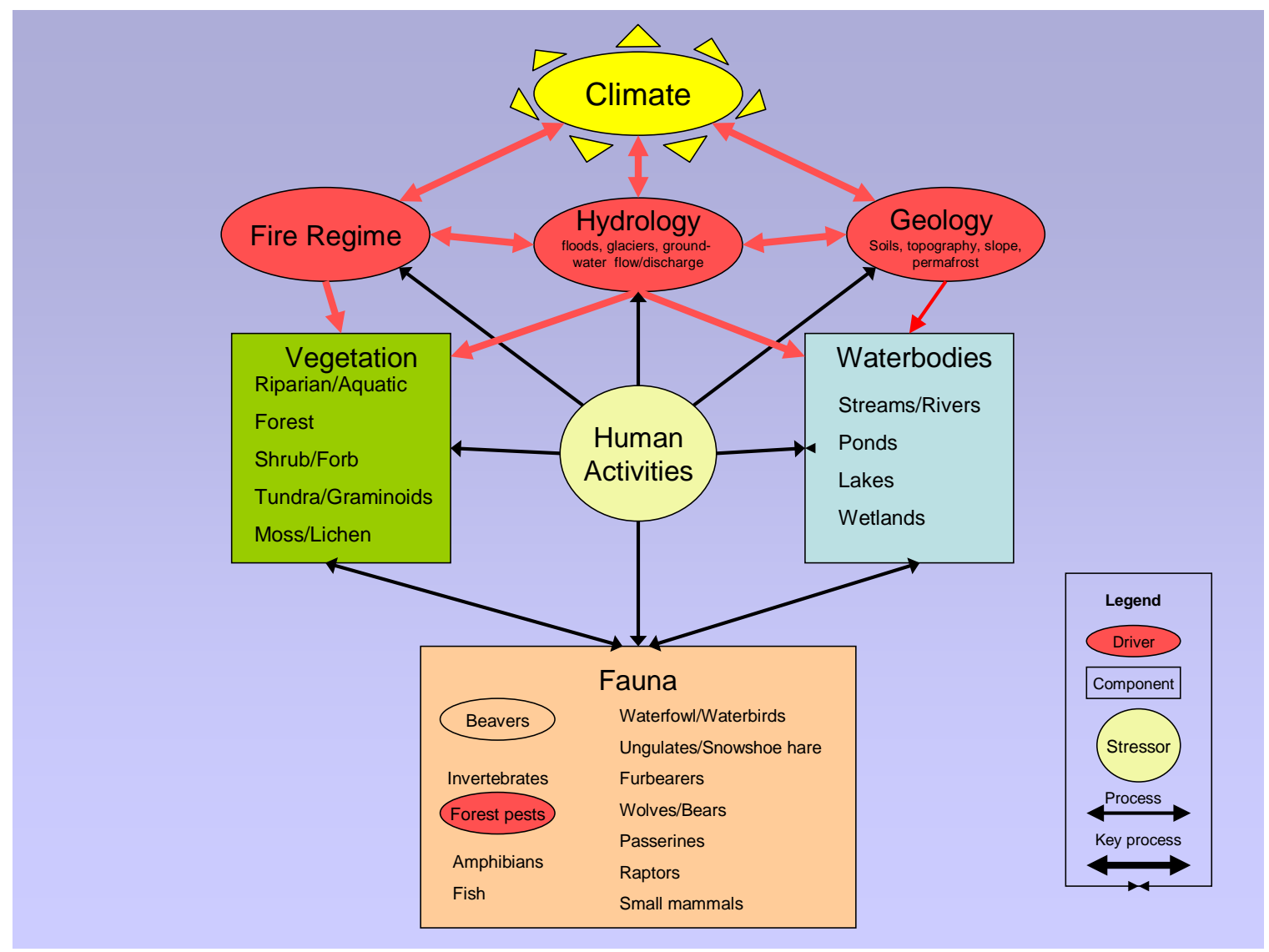

Figure A9.1. Conceptual model of Tetlin NWR. Drivers are displayed as ovals, components as boxes, and stressors as circles. Model elements are linked by processes shown as lines with arrows. Elements most likely to respond to climate change are shown in red.

\section{Stressors}

In our model (fig. A9.1), we define stressors as perturbations to the ecosystem that are either foreign to that system or natural to the system but applied at levels thought to be excessive or deficient. We identified a number of outcomes related to anthropogenic activities that are stressors in our model. Human activities include timber harvest, placer mining, road construction, pipeline construction, fire suppression, predator control, hunting and fishing. Some examples of potential outcomes associated with human activities include non-native invasive plants, soil compaction, runoff, changes in species distribution, and soil and water contamination.

\section{Potential Effects of Contemporary Climate Change}

Climate is the overriding driver in this conceptual model (fig. A9.1) directly influencing fire regime, hydrology, and geology. Consequently, a warming climate will have profound effects on all model components.

A recent synthesis of studies by Serreze and others (2000) provided evidence that the Arctic climate has warmed significantly over the last 30 years. On the Tetlin NWR, annual mean temperatures from Northway Airport increased by $1.5^{\circ} \mathrm{F}$ from 1951 to 2000. During the same period, mean daily 
temperatures for the month of January increased by $3.95^{\circ} \mathrm{F}$. If the current warming trend continues, it is projected that extensive permafrost instability and degradation will occur from 2015 to 2025

(Romanovsky and others, 2001). This warming and thawing of permafrost will result in extensive areas of thermokarst terrain (marked subsidence of the surface resulting from thawing of ice-rich permafrost). Because local hydrological processes are shaped by the presence or absence of permafrost, as permafrost degrades, the interaction of surface and sub-permafrost ground water processes will become increasingly important (Hinzman and others, 2005). Ice-rich permafrost prevents surface water from infiltrating into groundwater zones, creating saturated surface soils while maintaining wetlands. Degrading permafrost may led to drainage of lakes and wetlands, increased winter stream flows, decreased summer peak flows and changes in stream water chemistry (Hinzman and others, 2005).

A refuge specific simulation model predicts that Tetlin Refuge will become warmer and drier over the next 100 years (Rupp and Springsteen, 2009). Although precipitation is expected to increase during this time period, that increase is not likely to be sufficient to counter the increased evaporation and general drying resulting from the higher temperatures. This change will result in substantial increases in landscape flammability and fire activity particularly mid and late century. Consequently, large regions of mature unburned spruce existing today will likely be replaced by a more patchy distribution of deciduous forests and younger stages of spruce. Changes in the fire regime will likely occur as less flammable deciduous vegetation becomes more dominant on the landscape.

The impact of a warming climate on the primary drivers in the model will in turn affect the vegetation and faunal components. Warming in Alaska over the last century has been accompanied by the widespread advance of trees into tundra ecosystems (Hinzman and others, 2005). The advance of treeline into sub-alpine habitats on the Refuge may alter the distribution of the animals that live there. Warmer, drier summers in interior Alaska may lead to higher drought stress in white spruce and greater incidence of wildfire, both which may cause an increase in the abundance of forest insect pests. Forest defoliators eat leaves and needles of forest trees, but usually do not kill the tree. Their major impact is to slow tree growth and increase susceptibility to other insects and diseases. During outbreaks, forest pests may also influence the distribution and abundance of some landbirds that feed on them. Warmer temperatures will also affect migratory animals by extending the breeding season and changing the timing and availability of resources. In particular, long-distance migrants that breed in Alaska are especially sensitive to phenological shifts in their breeding habitat because of the relatively short timewindow for optimal breeding conditions. For example, warmer spring temperatures on the breeding grounds of some migrant landbirds may lead to changes in the timing of peak abundance of invertebrates important as prey. Some species may be able to adapt to this change in food supply by advancing their breeding and egg-laying date. However, for many migrants the timing of spring migration is triggered by cues that are unlinked to the climate at their breeding grounds. Consequently, their breeding date is dictated by their arrival date leading to a disruption in the synchrony of life history events to food peaks. There is also evidence that an extended breeding season has resulted in range shifts e.g., Yellowbellied Flycatcher (Empidonax flaviventris; Benson and others, 2000) and increased productivity and population growth for Trumpeter Swan (Cygnus buccinator; Schmidt and others, 2009). 


\section{References}

Benson, A.-M., Pogson, T. H., and Doyle, T. J.: 2000, Updated geographic distribution of eight passerine species in central Alaska. Western Birds 31:100-105.

Chapin III, F. S., M. W. Oswood, K. V. Cleve, L. A. Viereck, D. L. Verbyla, editors. 2006. Alaska's Changing Boreal Forest. Oxford University Press, New York, New York, USA

Hinzman, L.D., N.D. Bettez, W.R. Bolton, F.S. Chapin, M.B. Dyurgerov, C.L. Fastie, B. Griffith, R.D. Hollister, A. Hope, H.P. Huntington, A.M. Jensen, G.J. Jia, T. Jorgenson, D.L. Kane, D.R. Klein, G. Kofinas, A.H. Lynch, A.H. Lloyd, D. McGuire, F.E. Nelson, W.C. Oechel, T.E. Osterkamp, C.H. Racine, V.E. Romanovsky, R.S. Stone, D.A. Stow, M. Sturm, C.E. Tweedie, G.L. Vourlitis, M.D. Walker, D.A. Walker, P.J. Webber, J.M. Welker, K.S. Winker, and K. Yoshikawa. 2005. Evidence and implications of recent climate change in Northern Alaska and other Arctic regions. Climatic Change 72: 251-298.

Kasischke, E. S. and B. J. Stocks (eds.). 2000. Fire, Climate Change, and Carbon Cycling in the Boreal Forest. Springer-Verlag, New York, New York, USA.

Krebs, C. J., S. Boutin, R. Boonstra, editors. 2001. Ecosystem Dynamics of the Boreal Forest: The Kluane Project. Oxford University Press, New York, New York, USA.

Romanovsky, V.E., T.E. Osterkamp, T.S. Sazonova, N.I. Shender, and V.T. Balobaev. 2001. Permafrost temperature dynamics along the East Siberian transect and an Alaskan transect. Tohoku Geophysical Journal 36:224-229.

Rupp, T.S and A. Springsteen. 2009. Summary Report for Tetlin National Wildlife Refuge: Projected Vegetation and Fire Regime Response to Future Climate Change in Alaska. January $26^{\text {th }}, 2009$.

Schmidt, J. S., M. S. Lindberg, D. S. Johnson, B. Conant, and J. King. 2009. Swan population growth using bayesian hierarchical models. Journal of Wildlife Management 73(5):720-727.

Serreze, M.C., Walsh, J.E., Chapin, F.S., Osterkamp, T., Dyurgerov, M., Romanovsky, V., Oechel, W.C., Morison, J., Zhang, T., and Parry, R.G. 2000. Observational evidence of recent change in the northern high-latitude environment. Climatic Change 46:159-207.

U.S. Fish and Wildlife Service. 2004. Tetlin National Wildlife Refuge Biological Program Review Briefing Book. Tetlin National Wildlife Refuge, Tok, Alaska, USA. 


\title{
Appendix 10. INTERIOR ALASKA ECOREGION-Yukon Flats NWR
}

\author{
By Mark Bertram, Supervisory Biologist, Yukon Flats NWR
}

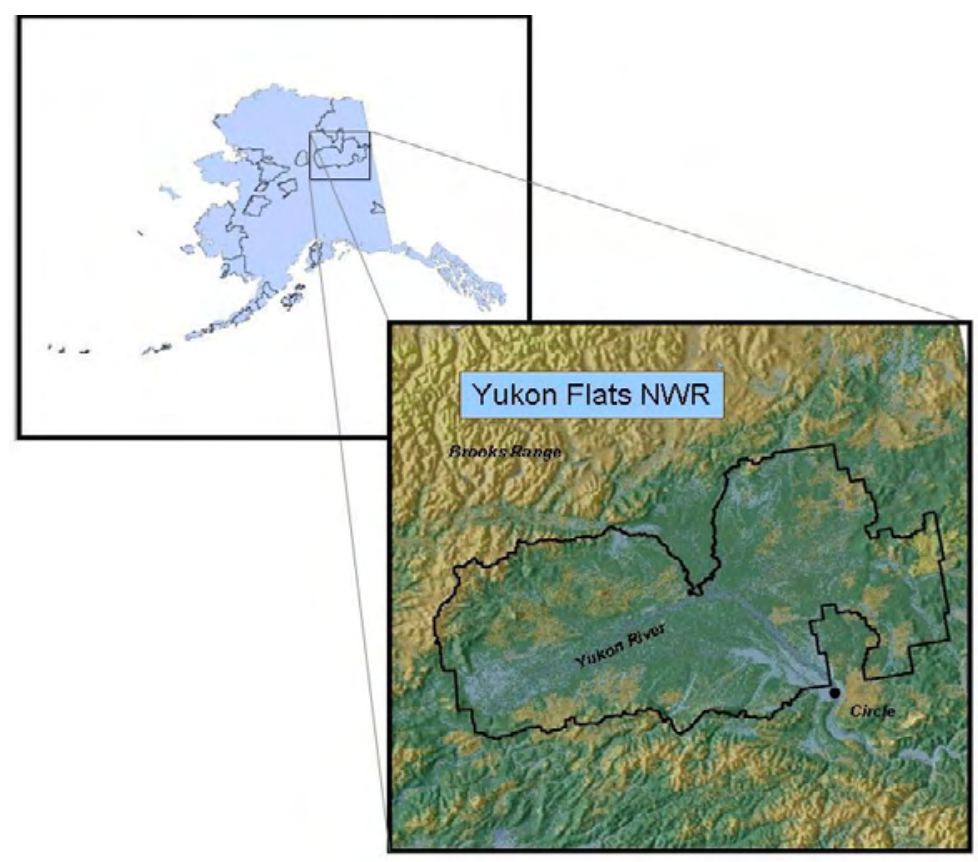

\section{Geographic Context}

The Yukon Flats National Wildlife Refuge (Refuge), situated in the Yukon Flats Basin in the eastern part of interior Alaska, is shielded on the north by the Brooks Range, on the south by the Crazy and White Mountains, and on the west by the Hodzana Highlands. A 300-mile stretch of the Yukon River bisects the Refuge and is the dominant physical feature.

The nature of the Yukon Flats conceptual model (figs. A10.1 and A10.2) is simplistic and designed to identify major drivers, broad categories of stressors, and significant functions that drivers provide for the system. The purpose of the model is to identify critical data gaps.

\section{Climate}

These topographic barriers and the remoteness of the Yukon Flats from open ocean areas tend to prevent the inland movement of moist maritime air masses, resulting in a continental climate with extreme winter and summer temperatures accompanied by low annual precipitation. Precipitation in much of the Yukon Flats Basin ranges from 10 to 30 inches annually and is directly related to topography - uplands receive the greatest amounts of precipitation and lowland areas receive the least. 
The region also has the highest fire frequency of any ecoregion in interior Alaska with a mean fire return cycle of about 109 years, on average about 1\% of the Refuge burns each year. The number of annual acres burned is highly variable and can range from more than 1 million to 0 acres. More than 3.5 million acres have burned on the refuge since 1980.

\section{Abiotic Components}

The Refuge is comprised of complex and diverse categories of terrestrial (alpine, uplands, lowlands) and aquatic habitats (wetlands, rivers, streams, ponds), which comprise the surface landforms which change due to drivers and stressors.

In addition to the Yukon River, an additional 7,100 mi of rivers comprise tributaries to the Yukon River watershed and more than 20,000 ponds are in the lowlands. Soils have not been mapped on the Yukon Flats but are thought to include entisols and inseptisols in the lowlands and gelisols in the highlands. The region is underlain by discontinuous permafrost.

The range of wetland conditions found on the Refuge is more diverse and expansive than other regions of interior Alaska and provide optimal breeding habitat for a wide range of breeding waterbirds. Wetlands are classified as freshwater bogs, freshwater and brackish water marshes, and alkali wetlands. The nutrient content in wetland waters varies by water depth, wetland substrate, and surrounding vegetation and topography and influences resource use.

\section{Biotic Components}

The complex and diverse habitats present on the Refuge support significant fish and wildlife populations. A total of 19 fish species have been documented on the Refuge. Resident species that undergo limited spawning migrations and inhabit deep water rivers and lakes include Arctic lamprey (Lampetra japonica), Arctic grayling (Thymallus arcticus), burbot (Lota lota), lake chub (Couesius plumbeus), longnose sucker (Catostomus catostomus), northern pike (Esox lucius), round whitefish (Prosopium cylindraceum), trout-perch (Percopsis omiscomaycus), slimy sculpin (Cottus cognatus), and Dolly Varden (Salvelinus malma). Migratory species include Pacific salmon (chum [Onchorynchus keta], Chinook [Onchorhynchus tshawytscha] and coho [Onchorhynchus kisutch]), whitefish (broad whitefish [Coregonus nasus], least cisco [Coregonus sardinella], humpback whitefish [Coregonus pidschian], and Bering cisco [Coregonus laurettae]), and inconnu or sheefish (Stenodus leucichthys). Yukon River waters between Fort Yukon and Circle include significant spawning grounds for whitefish species. Approximately 158 bird species have been recorded on the Refuge. Waterfowl that converge in very high breeding densities in the Yukon Flats Basin from four continents during spring migration are of national and international significance. Dominant species include American wigeon (Anas americana), mallard (Anas platyrhynchos), northern pintail (Anas acuta), northern shoveler (Anas clypeata), green-winged teal (Anas crecca), lesser scaup (Aythya affinis), canvasback (Aythya valisineria), and white-winged scoter (Melanitta fusca). Thirty-seven species of terrestrial mammals are known to occur within the Refuge. Low to moderate densities of big game species common to Interior Alaska such as moose (Alces alces), caribou (Rangifer tarandus), grizzly bears (Ursus arctos), Dall's sheep (Ovis dalli), and wolves (Canis lupus) are known to occur with the exception of black bears (Ursus americanus), which likely occur at relatively high densities. Both the Yukon Flats lowlands and highlands include high quality habitats for a diversity of furbearers such as lynx (Lynx canadensis), red fox (Vulpes vulpes), marten (Martes americana), snowshoe hare (Lepus americanus), mink (Mustela vison), wolverine (Gulo gulo), river otter (Lontra canadensis), beaver (Castor canadensis), and coyote (Canis latrans). 


\section{Ecosystem Drivers}

Similar to other regions of interior Alaska, fire, erosion/deposition and hydrology are the primary ecological drivers of ecosystems within the Yukon Flats Basin (fig. A10.1). Topography in and around the Yukon Flats and the underlying physical structure (geology, soils and permafrost) heavily influence ecological drivers.

The hydrology of the Yukon Flats region is complex and not well studied, but the cycle is a somewhat predictable annually: freeze-up, declining winter flows to base-flow conditions, break-up (often with ice jams, ice scouring and overbank flooding), summer flows with storm and drought events, returning to freeze-up. The timing, magnitude, and duration of the hydrologic cycle vary annually due to weather and climatic conditions. The hydrologic system is likely a continuum as described in previous studies, in that regional groundwater flow systems are recharged in uplands and discharged in lowlands. However, the processes which may control connectivity between surface and subsurface waters are largely unknown. Understanding the hydrology of the Yukon Flats Basin is an essential component to effectively managing the land. Currently, USGS is drafting a hydrology model of the Yukon Flats.

River and lake ice conditions are significant components of the hydrologic cycle on the Yukon Flats. Water inputs into Refuge tributaries are through snowmelt. Water discharge is much greater during snowmelt than during winter, even if snowfall and rainfall are below average. Most runoff occurs from May to September; however, the timing of runoff in the rivers differs, depending on the particular drainage basin characteristics.

The Yukon River and some of its tributaries are prone to flooding, with some of the extreme flooding in Alaska occurring along the Yukon River. The major flood mechanism is from ice jams during spring break-up, although flooding from ice jams appears to have become less frequent than in the past. Major floods due to ice jams have occurred at Fort Yukon in 1949, 1972, 1982, 1989, and 2009. Gauging stations were not installed along the Yukon River until the 1940s and 1950s, so the flood history before then is not well documented. Ice jams occur during spring thaw when broken ice collects in shallow or narrow points along the river channel or along sharp bends in the river. Water collects behind the ice jam and floods adjacent lands. Ice jams eventually break loose and discharge waters at high velocity, creating additional flooding conditions downstream.

Yukon River tributaries can also flood in the summer rainy season. For instance, the White Mountains that border the southern boundary of the Refuge can discharge heavy runoff from precipitation in early summer that floods Beaver, Preacher, and Birch creeks. In this region summer storms are a significant force in recharge of floodplain ponds.

Ecological drivers in the Yukon Flats can act independently or influence the landscape in combination. Fire can be effective in mobilizing nutrients through erosion processes and have direct effects on wetland nutrient composition. Fire may also be affected by hydrology, which may buffer the incidence, rate of spread, and effect of fire on habitat structure. Fire also may influence the release of carbon from aerobic boreal soils.

A recent biological review identified the following specific stressors: (a) proposed land exchange which includes proposal for oil and gas development, (b) proposed release of wood bison (Bison bison athabascae), (c) dispersal of contaminants into the landscape through deployment of sounding rockets without retrieval, (d) proposed road from the haul road to Stevens Village, (e) introduction of invasive plants in Yukon Flats Basin, and (f) changing climate. 
Analyses of historical imagery and photography indicate that wetland change is occurring across the Yukon Flats Basin. Although the overall trend is less water across the region since 1980, there is also change in wetland heterogeneity. While some ponds are drying, other neighboring ponds are increasing in water volume. The processes controlling these changes as well as the water connectivity between wetlands in the region are not well understood.

\section{Potential Effects of Contemporary Climate Change}

Two climate modeling projects have been completed for the Yukon Flats (Springsteen and others, 2008; Rupp and Springsteen, 2009). Projected environmental changes include: alterations to hydrological systems and processes including drying of wetlands and interruption of water flow; permafrost degradation; increased fire regimes (frequency, intensity, size, extent, and longer fire seasons); increase in frequency, duration and extent of stressors to forest health (insects and disease), altered treelines; a long term transition from coniferous to deciduous dominated forests; earlier spring melting and changes in flood magnitude; changes in species phenology, distributions, and physiology; range shifts of invasive non-native species; effects to the prevalence and intensity of both plant and animal diseases; effects to salmon habitat/stocks; adaptation required by subsistence users; and increased urbanization and economic pressures which promote habitat loss and fragmentation. Currently, many of these expected impacts are being addressed in a USGS climate change initiative focused on the Yukon River Basin and more specifically on Yukon Flats ponds.

\section{References}

Rupp, T.S., and A. Springsteen. 2009. Summary report for Yukon Flats National Wildlife Refuge: Projected vegetation and fire regime response to future climate change in Alaska. Unpublished USFWS report, Fairbanks, Alaska.

Springsteen, A.L., Loya, W.M. and Rupp, T.S. 2008. Climate change scenarios and implications for Yukon Flats National Wildlife Refuge in Alaska. University of Alaska Fairbanks Network for Alaska Planning Report. 


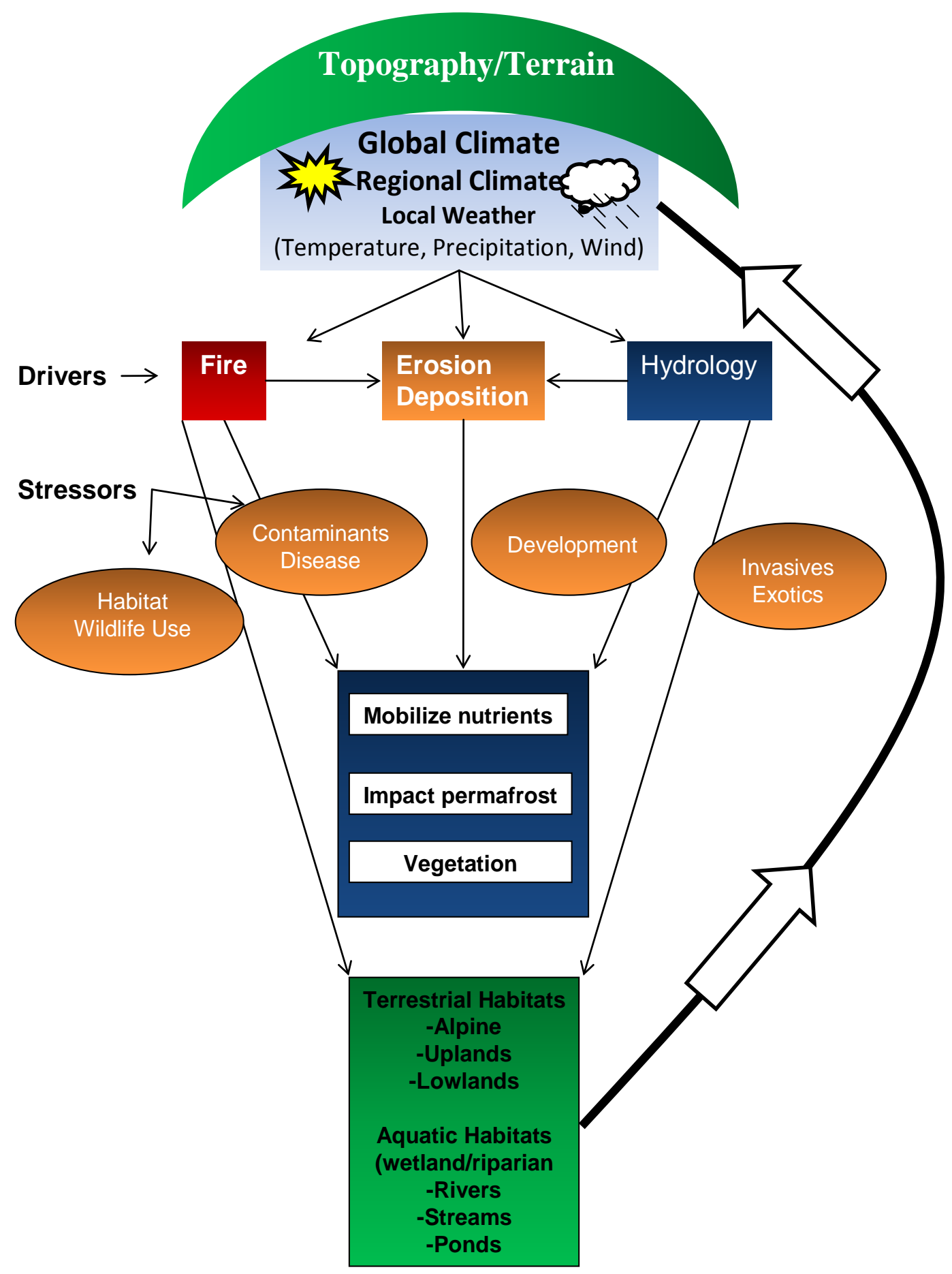

Figure A10.1. Conceptual model of drivers of Yukon Flats NWR. 


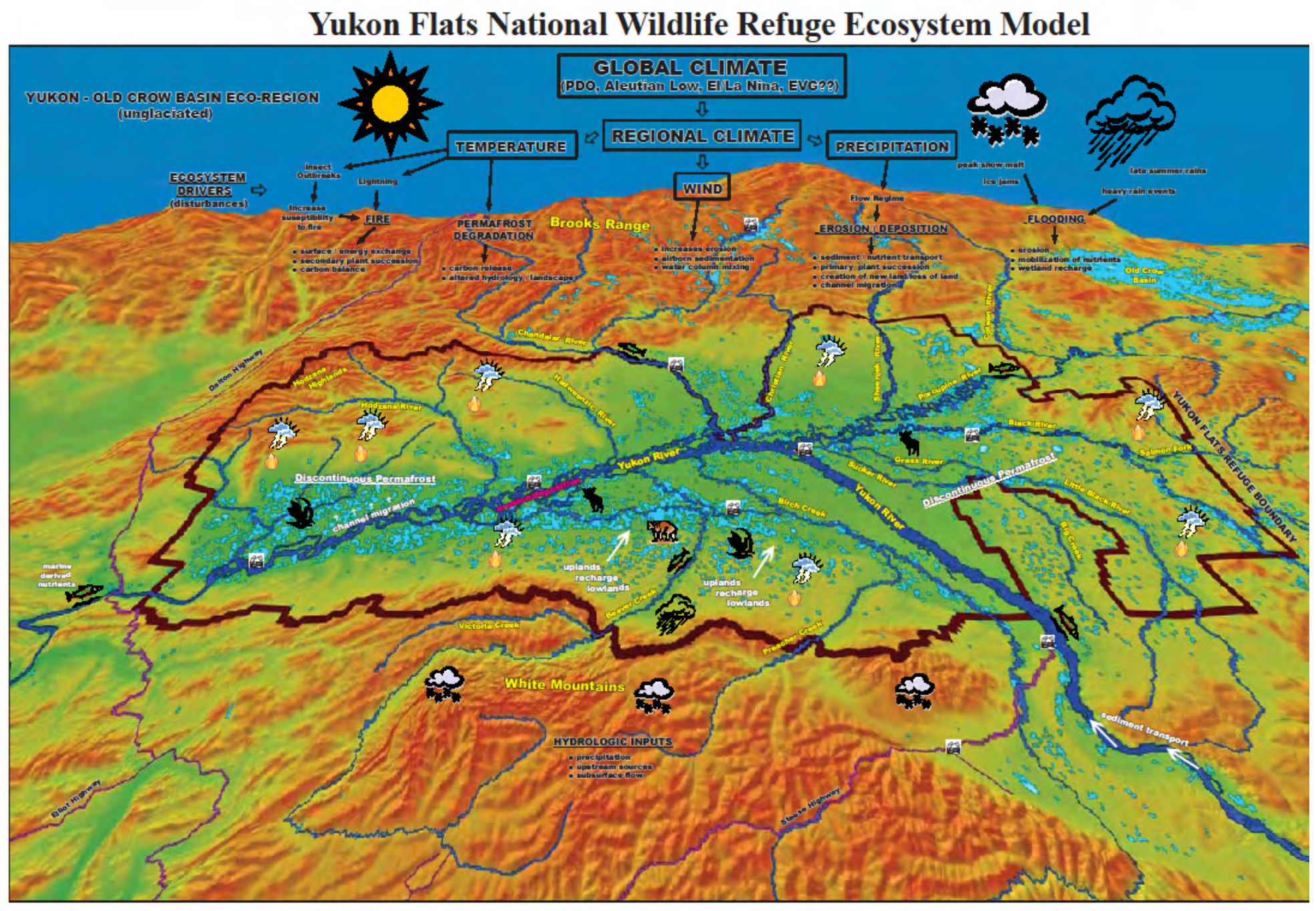

Figure A10.2. Conceptual model of Yukon Flats NWR. 


\section{Appendix 11. NORTH PACIFIC COAST ECOREGION-Alaska Maritime NWR}

By Vernon Byrd, Supervisory Biologist, Alaska Maritime NWR

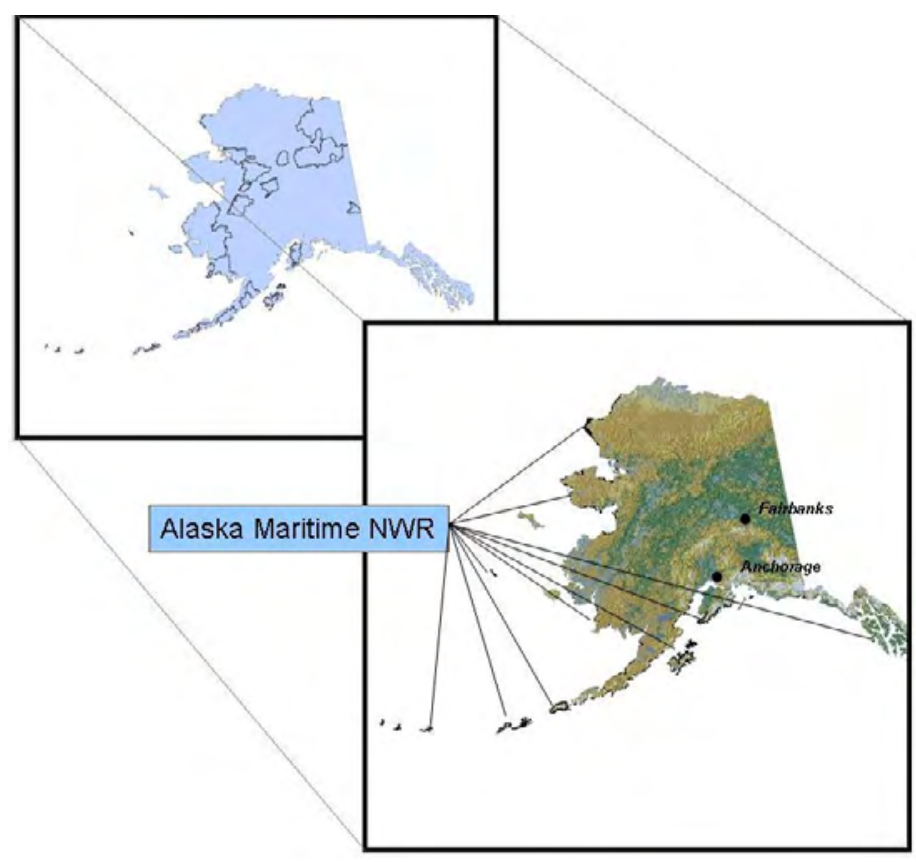

\section{Geographic Context}

The Alaska Maritime NWR consists of approximately 2,500 islands, islets and offshore rocks (plus a small amount of acreage on the mainland). Surrounding this massive and far-flung assemblage of islands in all areas of coastal Alaska are the Chukchi and Bering seas and the North Pacific Ocean. Although very little of the marine area is part of the refuge, the ocean is the primary habitat for many of the species for which the refuge was created (seabirds and marine mammals). Any conceptual model of the refuge must include this marine component despite the fact it is not within the boundary of the refuge (fig. A11.1).

\section{Climate}

Alaska Maritime NWR spans the full range of marine climates from the maritime climate of the southeastern Alaska to the polar climate north of the Arctic Circle. The largest unit of the refuge occurs in the Aleutian Islands. Here the climate is oceanic with relatively moderate and uniform temperatures, heavy rainfall and nearly constant fog. In the summer, temperatures are cooler than Southeast Alaska, but in the winter they are similar. Winter weather is driven by the Aleutian low pressure system, which creates strong winds and severe storms. 


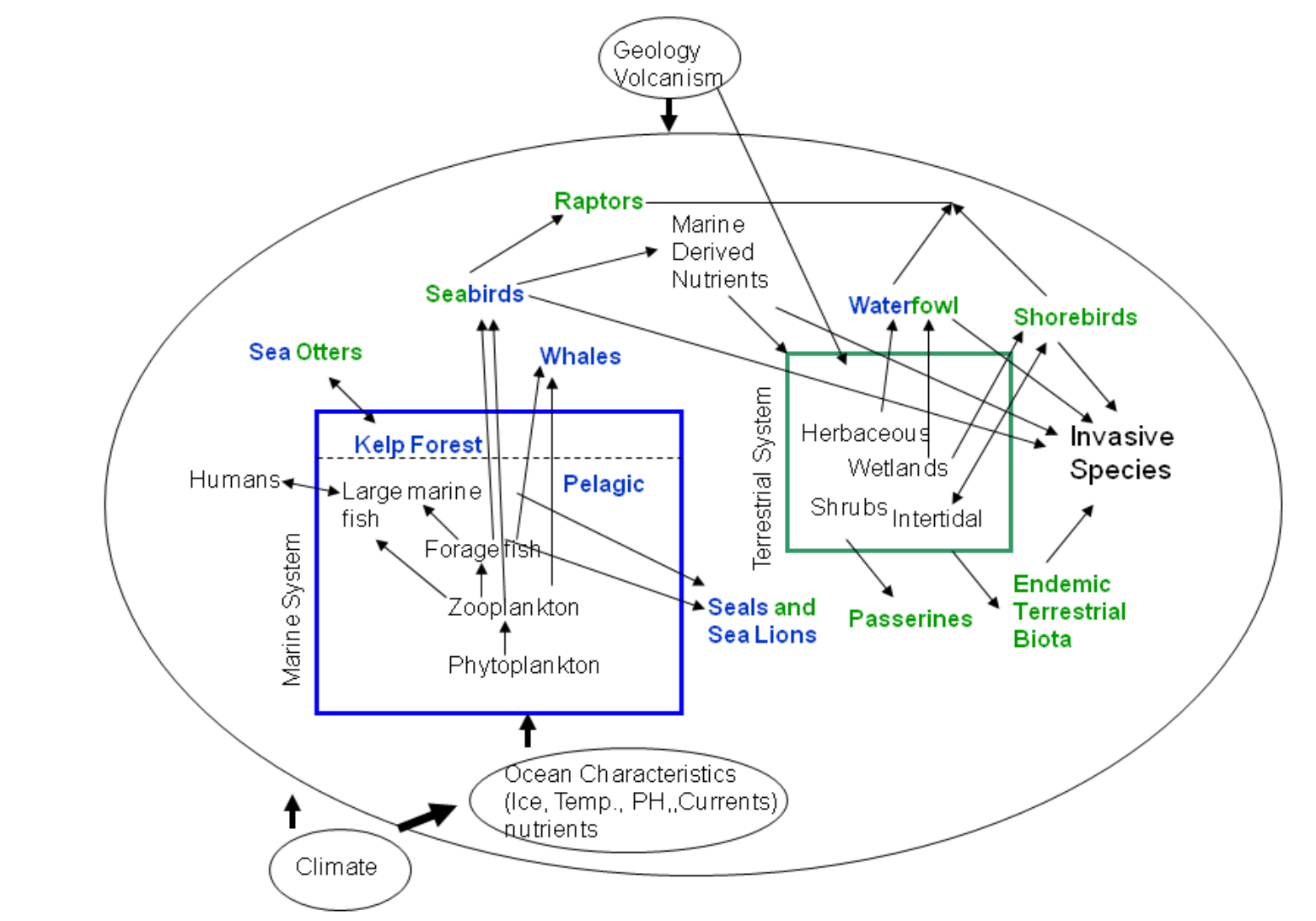

*Applies primarily to oceanic islan ds in the tundra ecoregion s—sea ice only a factor in Bering and Chukchi Units (blue in dicates Primarily marine, green primarily terrestrial, blue and green feed at sea, breed or haul out on land) .

Figure A11.1. Conceptual model of Alaska Maritime NWR.

\section{Abiotic Components}

The terrestrial subsystem is primarily oceanic islands ranging in size from 1 million acres (Unimak Island) to less than 1 acre. Most of the islands are volcanic in origin (and many are still active) and wetlands are scarce in the porous soils except on the larger islands where scattered streams and small, usually shallow ponds are present.

The marine subsystem of the conceptual model (fig. A11.1) represents the nearshore coastal waters. The Aleutian Island, Bering Sea and Alaska Peninsula Units of the refuge are subject to winter storms generated by the Aleutian low whose effects impact the nearshore marine, intertidal and island coastline zones, mainly through wave action.

Strong storms, driven by the Aleutian low pressure system, have a large impact on the nearshore marine, intertidal and island coastline zones. The marine subsystem includes the nearshore coastal waters. The Aleutian Islands form a barrier between the north Pacific Ocean and the Bering Sea. Strong ocean currents, particularly through passes between islands tend to concentrate prey for top level marine predators. 


\section{Biotic Components}

Vegetation in the Aleutians Islands, some of the islands off the Alaska Peninsula and in the southern Bering Sea is maritime tundra with only low shrubs and no trees. Alders (Alnus spp.)and taller willows (Salix spp.) occupy the islands closer to the mainland in the Bering Sea and along the Alaska Peninsula, and a few refuge islands in the Gulf of Alaska have spruce (Picea spp.) forests. The islands also provide nesting and breeding areas for world-class concentrations of marine birds ( $30-40$ million birds of 35 species) and marine mammals (hundreds of thousands of 5 species).

The terrestrial subsystem is relatively rich in endemic flora and fauna, particularly at the subspecies level because of the isolation of the oceanic islands.

\section{Ecosystem Drivers}

Geology and volcanism are the primary drivers for the terrestrial system, while oceanography and climate are the primary drivers for the marine system - however the two are closely intertwined. For example, volcanic activity created and continues to change most of the islands, with geologic processes constantly changing the shape and structure of the land and thus the habitat for terrestrial species. These same processes change the structure of the undersea floor, which is important to many physical forces such as currents and upwelling zones. Global climate can determine sea surface temperature in waters surrounding the refuge and is a major structuring agent for the marine component of the conceptual model. The amount of storminess, which affects mixing of waters and ocean productivity, or calmness which can produce stratification of water layers are processes operating at the level of days and weeks. Some oceanographic weather phenomena such as El Nino and La Nina determine ocean conditions at the scale of multiple years, while others operate at decadal levels (e.g. Pacific Decadal Oscillation - a composite index of climate).

Most of the species for which the refuge is important spend a small portion of their life cycle on land and a much larger portion at sea. The land primarily provides nesting habitat for bird species and haul-out/breeding habitat for marine mammals. Life in dual habitats means that seabirds can be a strong driver of the transport of marine-derived nutrients to the terrestrial system. The presence of seabirds can also determine vegetative community structure on islands. The structure of the nearshore system in southeast, south central and southwest Alaska is heavily influenced by sea otters, a keystone species whose predation on sea urchins determines community structure. In the northern areas of the refuge, the presence of sea ice and the location of the ice edge can be an important determinant of ocean productivity and can affect numerous species using the refuge. The biological system is alternately viewed from a top-down or a bottom-up perspective (with drivers being either large marine mammals, or phytoplankton/zooplankton concentrations).

Almost certainly the greatest threat to the terrestrial ecosystem is invasive species - the effects of introduced foxes (Vulpes vulpes) and rats (Ratus norvegicus) on seabird populations have been clearly established. For example, the introduction of foxes created a cascade effect in changes within the terrestrial system. It has been established that as foxes prey on nesting seabirds directly, they reduce the amount of marine-derived nutrients brought ashore by seabirds, which alters terrestrial vegetation and even affects soil productivity and invertebrate communities. Long-term climate change poses the greatest threat to the marine system - changing sea temperature and wind patterns affect where prey concentrates. Direct human impacts to the terrestrial system include oil spills, and localized development. Resource extraction by humans (e.g., commercial fishing) is likely a major driver in the marine system with many effects at several levels throughout the conceptual model. 


\section{Potential Effects of Contemporary Climate Change}

Marine organisms are particularly sensitive to temperature-driven changes in marine conditions. Interannual differences can affect food webs sufficiently to cause responses in timing of nesting events and reproductive success, leading ultimately to population change. Some sudden large shifts, like those in El Nino southern oscillations, can cause large scale reproductive failures and even die offs of adults. Shifts in distribution of plankton, forage fish, and predatory fish both vertically in the water column and geographically due to differences in temperatures and resulting stratification of the water column can restructure marine food webs substantially. Ocean acidification has the potential to drastically modify marine food webs, and have large impacts on marine birds and marine mammals.

Furthermore, the extent of winter and multi-year sea ice has a major impact on primary and secondary production and on the distribution of marine organisms. The reduction in the extent of the ice pack may cause a major restructuring in the Bering Sea shelf ecosystem. 


\section{Appendix 12. NORTH PACIFIC COAST ECOREGION-Alaska Peninsula and Becharof NWRs}

By Ron Britton, Supervisory Biologist, Alaska Peninsula/Becharof NWR

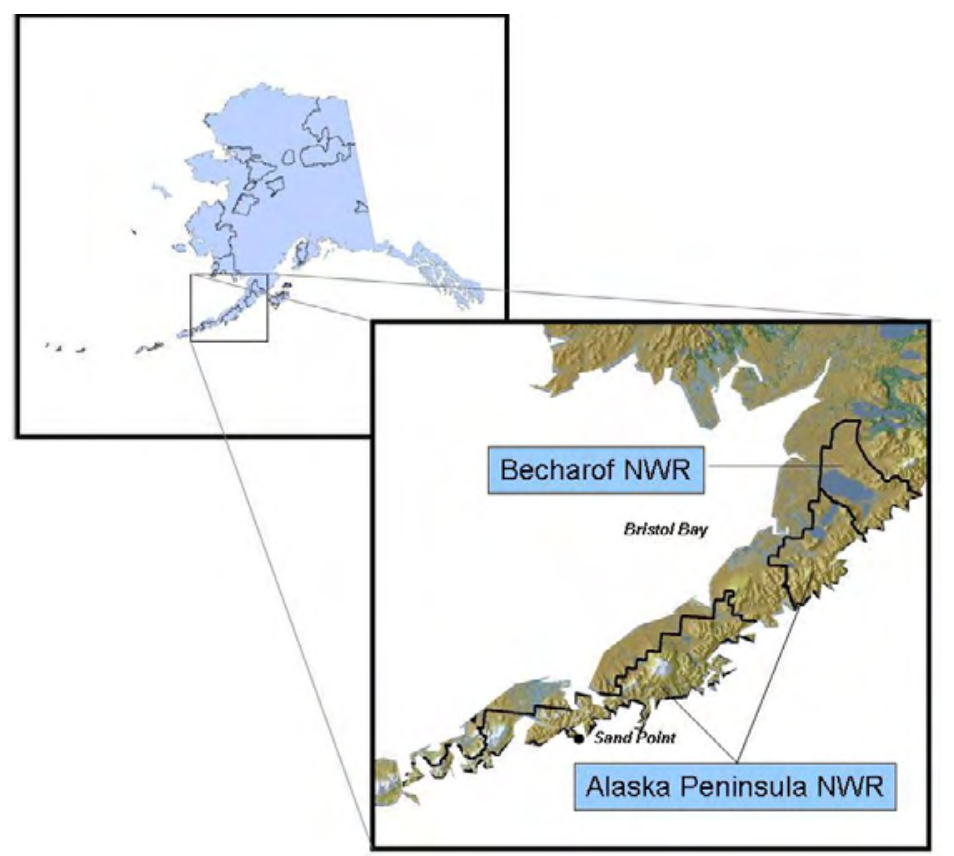

\section{Geographic Setting}

The Alaska Peninsula and Becharof National Wildlife Refuges both lie on the Alaska Peninsula and comprise more than 4.2 million acres of land including approximately 500,000 acres of Wilderness designated under the Alaska National Interest Lands Conservation Act (U.S. Fish and Wildlife Service, 2009a, 2009b). These lands are severely influenced by physical (geological and chemical), oceanographic, meteorological and climatological processes that are influential far beyond the refuges’ boundaries.

The physical processes combine to sculpt the land into diverse landscapes, from the rocky intertidal coastline that rises up from the deep Pacific Ocean depths on the south side of the peninsula to the North Pacific "rim of fire," including extant and extinct volcanoes, and the mountains resulting from the subduction of the Pacific Plate under the North American Plate. The geomorphologic features are further carved by the erosional forces of glaciation, surface water and ground water to form the uplands and plains landscapes down to the Bristol Bay-Bering Sea coastline. These abiotic processes are the most significant drivers affecting the landscape and environments that form the backdrop for the fish and wildlife inhabiting the refuges. 


\section{Climate}

Climactically, the peninsular refuges lie beneath an area of meteorological convergence and depending on the cycles, the surface winds are dominated by the warm and cool cycles of the Pacific Decadal Oscillation (Mantua, 1997) or the Arctic Oscillation, with its substantial contribution to the climate trends in recent decades (Wallace and Thompson, 1998; Wallace and others, 2002).

Oceanographic factors come into play through a balance of warm advection, adiabatic warming, and radiative cooling influence on currents and upwelling (Tanaka and Milkovich, 1990; Cummins and others, 2005). These climatic components, when coupled with the geomorphologic structures of the coastal mountains, the deep Pacific Ocean, and the shallower Bering Sea, combine to significantly influence the terrestrial conditions of the peninsula.

Developing the initial refuge model required an understanding of the interactions of these abiotic factors with the geomorphology of the landscape (figs. A12.1 and A12.2). In order to develop a more sophisticated model that accurately reflects the processes occurring on the refuges, a thorough accounting for the landscapes, the fish and wildlife present, their life histories and interactions, and the effects of the abiotic processes acting on them will have to be integrated into the project. A more sophisticated model will help us to prioritize inventory and monitoring, better manage the resources and eventually minimize threats to the resources.

\section{Refuge Model}

The current refuge model is a conceptual representation of the broad abiotic and biotic components occurring on the Alaska Peninsula (fig. A12.2). The model was developed to accommodate expansion into a quantifiably stochastic model capable of integrating existing research data into a system management framework. In order to accomplish this, a relational database capable of being developed and configured to accommodate a data structure similar to those used for coastal and marine geographic information data models (Zeiller, 1999; Bartlett, 2000; Li, 2000; Wright and others, 2001) must be applied. Eventually the selected database should be capable of supporting a method for integrating down to the "ground" level where the data are collected. The ultimate goal is to be able to enter the basic data, use these data for monitoring events and hopefully at some point provide predictive capabilities. At this stage of the modeling process, we are at the inventory stage with very limited monitoring capabilities and no predictive ability.

The Alaska Peninsula/Becharof National Wildlife Refuges model was developed by determining what primary resources, components and processes were currently acting on the refuge. The iterative process of listing and categorizing all the components made it clear that the exercise could not be demonstrated for both refuges but that a representative section should be selected. By looking at a map of the Alaska Peninsula, it was possible to find a drainage that contained a representative sample of most of the landscape types present on the refuges. The Ugashik River drainage was selected. Based on the list of resources, components and processes it was also clear that just adhering to refuge boundaries would possibly overlook many of the processes that affect the refuge, or possibly de-emphasize the effects. It was decided to include a cross section of the entire peninsula to include the adjacent offshore areas of the Bering Sea and the North Pacific Ocean.

The aerial view selected is a little more than three degrees of longitude on the $\mathrm{x}$-axis $\left(155^{\circ} 00^{\prime}\right.$ $\mathrm{W}$ to $\left.158^{\prime} 00^{\prime} \mathrm{W}\right)$ by twenty minutes of latitude on the y-axis $\left(57^{\circ} 20^{\prime} \mathrm{N}\right.$ to $\left.57^{\circ} 40^{\prime} \mathrm{N}\right)$. From the aerial view, the next step was to conceptualize the components from a side view by taking a cross section at the $57^{\circ} 30^{\prime} \mathrm{W}$ parallel of latitude through the entire plan view and reconstructing it to scale vertically in profile. The initial drawing illustrated the perspective and scale needed for an accurate geographical 
rendition and the sketch was developed into a diagrammatic model design (fig. A12.1). By using the bathymetry of the North Pacific Ocean and the eastern Bering Sea in conjunction with the topography of the coastal mountains and volcanoes, glaciers, streams, lakes, rivers, uplands and lowlands, the map features were superimposed onto the North American plate.

The profile view of figure A12.1 emphasizes the atmospheric, geologic, volcanic, oceanographic and hydrologic domination of the peninsula environment from the North Pacific Ocean to the coastal mountains, glaciers, and volcanoes, to the uplands, extensive river drainage, lake systems, and lowlands descending to the eastern Bering Sea. These are foundational elements upon which all of the processes interact to support the biotic communities that exist on the Alaska Peninsula. This view clearly represents the majority of the landscapes found on the refuges.

Figure A12.2 is the conceptualization of the abiotic processes along the same hypothetical cross section, trending roughly southeast to northwest (right to left) and with the addition of the primary components that are represented in each system, e.g. "North Pacific Marine System," with the coastal "Limnetic System" of both the Pacific Ocean and Bering Sea superimposed onto the "Terrestrial System." Contained within each of these "System" blocks are the "pyramids" of biotic organisms founded on the sediment and soil communities. In aquatic systems the sediment communities support benthos, and the water columns support phytoplankton, zooplankton, and nekton; while in the terrestrial system the soil communities support the vegetation, invertebrates and the vertebrates. The model does not currently illustrate all the specific abiotic and biotic components and processes found on the refuges. This conceptual list was selected as a template capable of expanding into a more detailed and specific list.

The primary components fit into four broad categories. The physical and chemical parameters fit into the "Abiotic Components" category. The physical, chemical and biological components that cannot be separated fit into the "Abiotic and Biotic Components” category. The specific biological floral and faunal parameters make up the "Biotic Components" category. The cycle, functions, etc. that act across all of these parameters include the fourth category, the Processes. The sub-components included in several of the categories provide more detail to the basic components found on the refuge.

\section{Summary}

The use of a more sophisticated and relational database model will allow for more rigorous mathematical and data-rich models to be both developed and integrated as they become available. For example, currently it should be possible to link existing research and modeling on Bering Sea marine food webs and fish migration (Aydin and others, 2005; Schindler and others, 2003, 2005) with the goal to test hypotheses for similar salmon runs on the peninsula refuges.

Currently, we have focused on identification of the primary and secondary components key to the refuge and establishing the suspected interrelationships between the components and processes. Based on the generalized model, the next step will be to determine how best to proceed with a more rigorous system management model, such as a Geographical Information System of management.

\section{References}

Aydin, K., GA. McFarlane, JR. King, BA. Megrey, and KW. Myers. 2005. Linking oceanic food webs to coastal production and growth rates of Pacific salmon (Oncorhynchus spp.), using models on three scales. Deep-sea Res, II. 52: 757-780.

Bartlett, D. J. 2000. Working on the frontiers of science: Applying GIS to the coastal zone. In Marine and Coastal Geographical Information Systems, edited by D. J. Wright and D. J. Bartlett, 11-24. London: Taylor \& Francis. 
Cummins, P.F., G.S.E. Lagerloef, G. Mitchum. 2005. A regional index of northeast Pacific variability based on satellite altimeter data. Geophysical Research Letters, Vol. 32, L17607, doi:10.1029/2005GL023642, 2005.

Li, R. 2000. Data models for marine and coastal geographic information systems. In Marine and Coastal Geographical Information Systems, edited by D. J. Wright and D. J. Bartlett, 25-36. London: Taylor \& Francis.

Mantua, N.J., S. R. Hare, Y. Zhang, J. M. Wallace, and R. C. Francis. 1997. “A Pacific interdecadal climate oscillation with impacts on salmon production.” Bulletin of the American Meteorological Society, June, 1997 (Vol. 78, pp. 1069-1079).

Schindler, DE, MD Scheuerell, JW Moore, SM Gende, TB Francis, WJ Palen. 2003. Pacific salmon and the ecology of coastal ecosystems. Frontiers in Ecology and the Environment 1:31-37.

Schindler, DE, PR Leavitt, CS Brock, SP Johnson, PD Quay. 2005. Marine-derived nutrients, commercial fisheries, and production of salmon and lake algae in Alaska. Ecology 86:3225-3231.

Tanaka, H.L., and M.F. Milkovich, 1990. A Heat Budget Analysis of the Polar Troposphere in and around Alaska during the Abnormal Winter of 1988/89. American Meteorological Society - Monthly Weather Review, Vol. 118, No. 8, August 1990.

U.S. Fish and Wildlife Service, Alaska Peninsula National Wildlife Refuge, 2009a. http://alaska.fws.gov/nwr/akpen/index.htm, accessed 23 June 2009.

U.S. Fish and Wildlife Service, Becharof National Wildlife Refuge, 2009b. http://alaska.fws.gov/nwr/becharof/index.htm, accessed 23 June 2009.

Wallace, J.M., D.W.J. Thompson, 1998. The Arctic Oscillation signature in the wintertime geopotential height and temperature fields, Geophysical Research Letters, 25, 1297-1300.

Wallace, J.M., I.G. Rigor, and R.L. Colony, 2002. Response of Sea-Ice to the Arctic Oscillation, Journal of Climate, 15, 2648-2663.

Wright, D. J., P. N. Halpin, S. Grisé, and J. Breman. 2001. ArcGIS marine data model, ESRI, Redlands, California. Retrieved from dusk.geo.orst.edu/djl /arcgis

Zeiller, M. 1999. Modeling our world: The ESRI guide to geodatabase design. Redlands, Calif.: ESRI Press. 


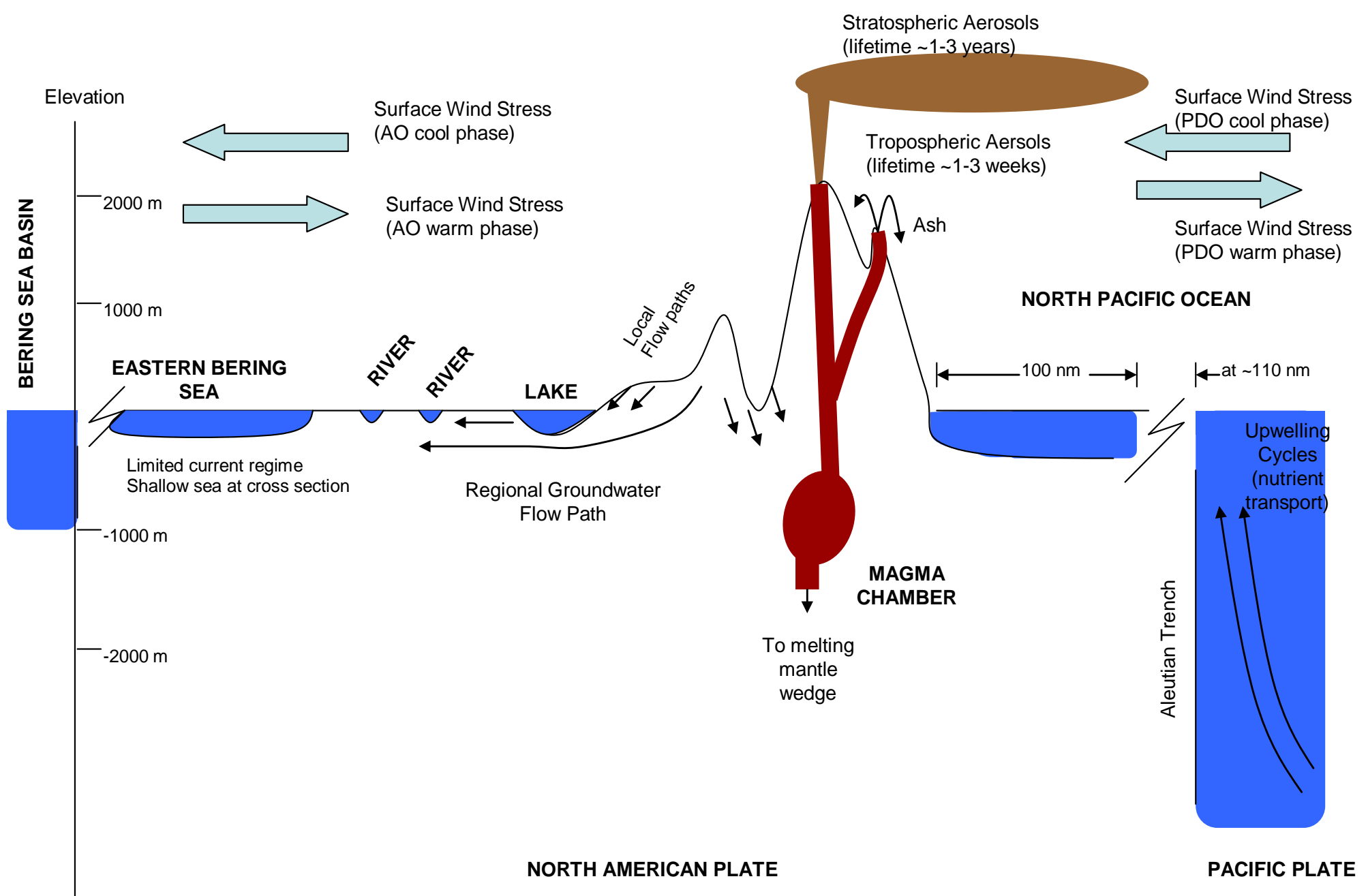

Figure A12.1. Conceptual model describing the geologic setting of Alaska Peninsula and Becharof NWRs. 


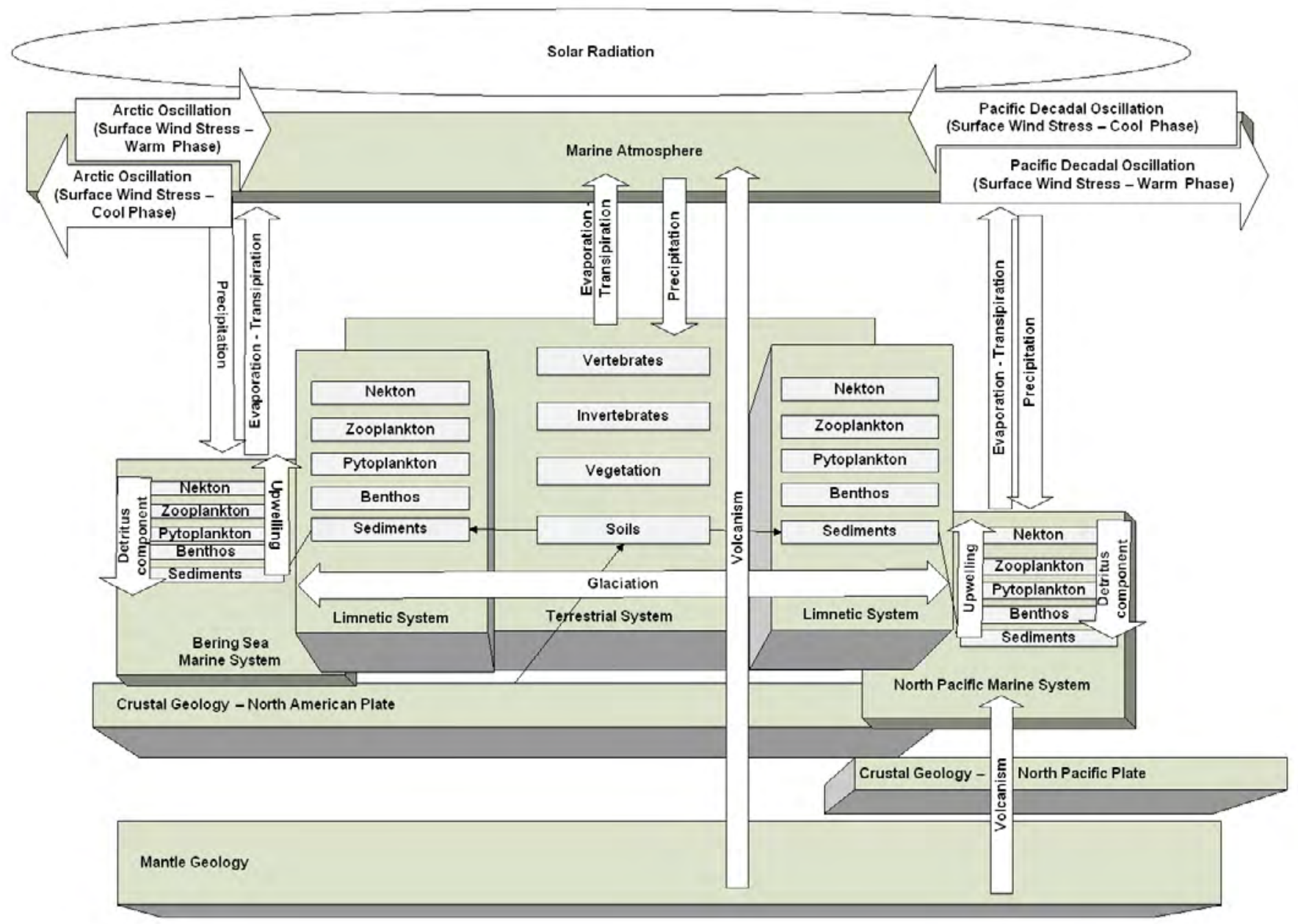

Figure A12.2. Conceptual model describing the interactions among climate, oceanography, limnology, geology, and biota in Alaska Peninsula and Becharof NWRs. 


\section{Appendix 13. NORTH PACIFIC COAST ECOREGION—Izembek NWR}

By Kristine Sowl, Supervisory Biologist, Izembek NWR

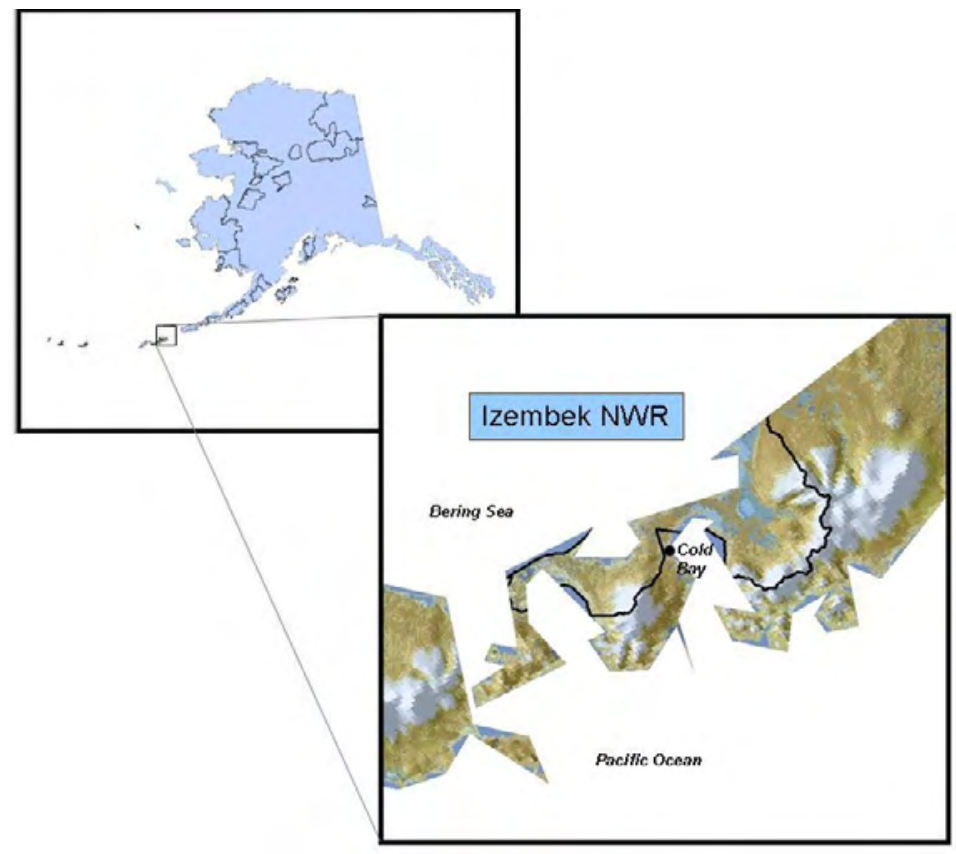

\section{Geographic Context}

Izembek National Wildlife Refuge (NWR), which encompasses 169,042 ha, is located on the Lower Alaska Peninsula in southwest Alaska with its headquarters in Cold Bay, Alaska. The southern end of the Peninsula forms a narrow strip between the Bering Sea and the Pacific Ocean, and the close proximity of the surrounding marine waters strongly influences regional climate and ecosystem dynamics. In addition to Izembek NWR, refuge staff administers three other refuge units due to their proximity and ecological similarities: the Pavlof and North Creek Units of the Alaska Peninsula NWR (585,930 and 3,422 acres, respectively) and the Unimak Island Unit of Alaska Maritime NWR (408,379 ha). The Pavlof Unit includes lands on the Pacific side of the Lower Alaska Peninsula extending from Port Moller to Isanotski Strait, while the North Creek Unit is adjacent to the northeast boundary of Izembek NWR. The Unimak Island Unit, one of the Aleutian Islands, is southwest of Izembek NWR and the Pavlof Unit across Isanotski Strait. The conceptual model (fig. A13.1) includes all management units and has the following purposes: (1) put ecosystem components that are currently being monitored into an ecosystem context, (2) identify components that may need to be monitored to adequately describe the ecosystem, and (3) look for opportunities to integrate monitoring across refuges. 


\section{Climate}

The climate of the southern Alaska Peninsula is a moderate polar maritime climate. Frequent cyclonic storms from the Northern Pacific and Bering Sea bring persistent clouds, high winds, moderate temperatures, and a constantly changing weather pattern. Temperature extremes, both seasonal and diurnal, are generally confined to fairly narrow limits $\left(4-16{ }^{\circ} \mathrm{C}\right)$. Sea winds with a high moisture content blow onto the Alaska Peninsula from both oceans, and precipitation is frequent but not abundant. Severe storms can occur year round and are often accompanied by intense winds.

Climatic influences operate at several scales. Large-scale climatic effects include climatic cycles such as the Pacific Decadal Oscillation (PDO), Arctic Oscillation (AO), and El Niño/Southern Oscillation. These climatic oscillations operate on large time scales and have widespread regional, if not global, effects. The ice pack that forms in the Bering Sea during the winter also has a large-scale impact on climate of the region. Extensive Bering Sea ice pack results in a more continental type climate, while a smaller ice pack results in a more moderate maritime climate. Smaller-scale climatic factors includes wind, precipitation, temperature (both air and water), cloud cover and fog, incident solar radiation, snow and ice cover, and storm events.

\section{Abiotic Components}

Abiotic components tend to be the same across many ecosystems and include water, terrain, soil, and location on the globe. The water component includes the amount, distribution, and chemistry of the water. Water is a dominant component of many of the ecological subsystems of the Lower Alaska Peninsula. The freshwater subsystem, which is interspersed within the terrestrial subsystem, includes rivers, streams, lakes, and ponds. The ecotone between the terrestrial and freshwater communities is the wetland subsystem and includes marshes, bogs, and springs. The estuarine subsystem interfaces with the marine, freshwater, and terrestrial subsystems. It includes coastal lagoons and estuaries on both the Pacific and Bering sides of the Lower Alaska Peninsula and Unimak Island. The marine subsystem includes the nearshore coastal waters along the Bering Sea and Gulf of Alaska sides of the Alaska Peninsula.

Terrain refers to slope, aspect, elevation, and landforms. Terrain influences water flow and distribution, incident solar radiation and air temperature, deposition and erosion, soil temperature and moisture, and local weather patterns. The terrain on Izembek NWR includes volcanoes, old lava flows, volcanic ash fields, glacial moraines, U-shaped mountain valleys, kettle lakes, rolling hills, tundra hummocks, low-lying wetlands, rocky cliffs, sand dunes, shallow-water lagoons, and deep-water bays. Soil type, chemistry, and moisture affects plant distribution and habitat type. Soils on Izembek NWR are derived from offshore shelf areas (sand and clay), past glaciation events (gravel and silt), decomposed bedrock, volcanic ash, and decomposition of plant material (mostly in wet tundra areas).

Global location impacts weather and climate, seasonal fluctuations in weather, solar radiation, and day length, and proximity to tectonic plate boundaries. Izembek NWR is located in the subarctic region between the shallow, highly productive Bering Sea and the southwestern edge of the Gulf of Alaska. The proximity of these seas influence climate and the extensive coastlines of the refuge are subject to coastal influences such as waves, currents, salinity, sea ice, and sea level changes. Day length varies from $171 / 2$ hours in the summer to 7 hours in the winter. The Lower Alaska Peninsula and Unimak Island are part of the Pacific Ring of Fire where the Pacific Plate is being subducted under the North American plate at the Aleutian Island arc. There is considerable tectonic and seismic activity in the area, and the refuge includes several active volcanoes (Shishaldin, Pavlof, and Mount Hague). 


\section{Biotic Components}

The lands managed by Izembek NWR include five ecological subsystems: terrestrial, wetlands, freshwater, estuarine, and nearshore marine habitats. Vegetation types and dominant fauna vary amongst these subsystems. The conceptual model (fig. A13.1) shows the five subsystems in columns. The width of the column does not indicate the relative importance of the subsystems. Inside the columns are various ecosystem components, including soil/substrate, plant groups, and trophic levels. Primary consumers eat plant material (essentially herbivores), secondary consumers eat other animals, and top predators include the highest trophic level of carnivores.

Terrestrial.- The terrestrial subsystem consists of treeless, subarctic tundra. Habitats vary along an elevational gradient from beach rye grass (Leymus mollis) meadows at sea level to alpine rock and scree or permanent snowbeds on rugged volcanic peaks that can exceed 2,500 m. Other habitats included in this subsystem are alpine heath, ericaceous heath, alder (Alnus spp.) and willow (Salix spp.) deciduous shrub thicket, graminoid-herbaceous meadows, snowbed meadows, and rocky outcrops (Talbot and others, 2006). Vegetation communities vary with moisture, soil type, solar and wind exposure, slope, and micro relief. Microrelief characteristics, such as hummocks, are frequently formed by freeze-thaw dynamics. The cool climate of the Alaska Peninsula results in relatively late leaf-out dates for shrubs (mid- to late-June), low decomposition rates, and slow plant colonization rates of unvegetated areas.

The communities of the terrestrial subsystem include a variety of flora and fauna. Dominant plants include crowberry (Empetrum nigrum), grass, sedge (Carex spp.), cottongrass (Eriophorum vaginatum), moss, alder (Alnus spp.), and willow. Some of the dominant animals at each trophic level include the following: invertebrates (bumblebees [Bombus spp.], flies, oligochaete worms, spiders), primary consumers (caribou [Rangifer tarandus], willow ptarmigan [Lagopus lagopus], arctic ground squirrels [Spermophilus parryii]), secondary consumers (insectivorous birds, shrews [Sorex spp.], red fox [Vulpes vulpes]), top predators (wolves [Canis lupus], wolverines [Gulo gulo], brown bears [Ursus arctos], bald eagles [Haleaeetus leucocephalus). Scavengers, such as red foxes and bald eagles, or omnivores, such as brown bears, may forage at more than one trophic level. Distance from the coast can impact distribution of fauna in this region. Shorebirds that forage in intertidal areas breed at higher densities near the coast, brown bears regularly patrol beaches for food when Pacific salmon (Onchorynchus spp.) runs are absent but move inland after salmon move upstream, and caribou often congregate nearer the coast when inland habitats have heavy snow cover.

Freshwater.-Freshwater habitats include lakes, ponds, and rivers that are interspersed amongst the terrestrial habitats. Water conditions are the dominant force in these habitats. Major plant communities are aquatic vegetation (Potamogeton alpinus, Ranunculus aquatilis) and algae. Fauna that occur in freshwater systems include invertebrates (aquatic insect larvae, freshwater snails, leeches), primary consumers (tundra swans [Cygnus columbianus], northern pintails [Anas acuta] and other dabbling ducks), secondary consumers (Pacific salmon, Dolly Varden char [Salvelinus malma], bank swallows [Riparia riparia], greater scaup [Aythya marila], black scoters [Melanitta americana]), and top predators (river otters [Lontra canadensis], brown bears, bald eagles).

Wetlands.-Wetlands include marshes, bogs, and springs. Riparian vegetation, wet meadows, and mires could be classified as either terrestrial or wetland. Some of the dominant species of wetland ecosystems include the following: invertebrates (midges, mosquitoes), primary consumers (caribou, dabbling ducks), secondary consumers (shorebirds, sandhill cranes [Grus canadensis], mew gulls [Larus canus]), and top predators (brown bears, gyrfalcons [Falco rusticolus]). 
Estuary.-Habitats in this subsystem include brackish water meadows, intertidal and subtidal meadows (eelgrass [Zostera spp.] and seaweeds), and tidal channels and flats. On the Lower Alaska Peninsula, eelgrass has been observed in many lagoons and estuaries, including Izembek Lagoon, which has one of the largest eelgrass beds in the world (McRoy, 1968; Ward and others, 1997). The eelgrass beds at Izembek NWR are extremely important foraging habitat for many migratory waterfowl species as well as fish, sea otters [Enhydra lutris], and other species of animals. Snails and crabs are abundant invertebrate grazers. Primary consumers include brant (Branta bernicla), cackling goose (Branta hutchinsii), emperor goose (Chen canagica), northern pintail (Anas acuta), American wigeon (Anas americana), mallard (Anas platyrhynchos), and green-winged teal (Anas crecca). The invertebrate fauna that live attached to or amongst the eelgrass are food for benthic and demersal fishes, sea stars, crabs, Steller's eiders (Polysticta stelleri) and other ducks, gulls, shorebirds, and sea otters. Brown bears and bald eagles fish for salmon in the lagoons and red foxes constantly forage in the intertidal areas. Top predators include harbor seals (Phoca vitulina) and Steller's sea lions (Eumetopias jubatus). Due to the richness of the ecosystems, there is also a tremendous transfer of nutrients between estuarine systems and the terrestrial, freshwater, and wetland systems. Rivers and streams transfer nutrients from terrestrial and wetland systems into estuarine areas, while tidal action exports nutrients and detritus from estuarine areas into marine and freshwater systems. Active transport of nutrients occurs through the movements of animals between the subsystems, particularly migratory waterfowl, shorebirds, salmon predators, and scavengers. Detritus from eelgrass is deposited on the beach or exported out of the lagoons into the ocean.

Nearshore Marine.-The marine subsystem includes the nearshore coastal waters along the Bering Sea and Gulf of Alaska sides of the Alaska Peninsula. Habitats in this subsystem include kelp forests and seaweed meadows. At the interface between marine waters and terrestrial habitats is marine beach shore and dune meadows (beach rye grass [Leymus mollis], sandwort [Arenaria lateriflora], and beach pea [Lathyrus japonicas var. maritimus]). Primary invertebrates in the marine system are benthic animals such as clams and crabs or pelagic invertebrates like zooplankton and jellyfish. Primary consumers are invertebrates, and fish. Secondary consumers include gray whales (Eschrichtius robustus), sea otters, sea ducks, and seabirds. Top predators include killer whales (Orcinus orca), harbor seals, and Steller's sea lions.

\section{Ecosystem Drivers}

Terrestrial. - Vegetation communities vary with moisture, soil type, solar and wind exposure, slope, and microrelief. Microrelief characteristics, such as hummocks, are frequently formed by freezethaw dynamics. The cool climate of the Alaska Peninsula results in relatively late leaf-out dates for shrubs (mid to late June), low decomposition rates, and slow plant colonization rates of unvegetated areas.

Freshwater.-Freshwater systems carry water from snow and glacial melt or rain from the mountains to the tundra and out to the ocean. Volume and timing of runoff and snow/glacial melt affect water levels in lakes and rivers, ground water recharge, sediment and nutrient transport, and erosion rates. Temperature, winds, and solar radiation affect evaporation rates and drying of lakes and ponds. Substrate type and distribution (fine sediment, gravel, cobble) is usually determined by water flow. Rivers and streams tend to be relatively short in length due to the narrowness of the peninsula. 
The freshwater subsystem provides an important conduit for the transport of marine nutrients into the wetland and terrestrial subsystems by anadromous salmon. Salmon spawn in all of the major drainages on the Refuge and are an essential component of terrestrial, freshwater, and marine food webs. Adult salmon provide food for brown bears, bald eagles, wolves, and other large predators, while salmon fry are important prey for fish, birds, and small mammals. The nutrients released from the decaying carcasses of spawned-out salmon recharge the freshwater ecosystems, including affecting the growth of salmon fry, and boost productivity of these and nearby terrestrial ecosystems. Vast numbers of migratory waterfowl forage on the invertebrates or aquatic plants of these nutrient-enriched systems. By contrast, lakes that are not part of salmon spawning systems tend to be oligotrophic and are used by few species. Salmon-derived nutrients are transferred into terrestrial systems when consumers carry carcasses onto the tundra and leave behind feces, but also from the decomposing carcasses of the animals that have consumed the salmon.

Wetlands.-Precipitation and snow/glacial melt affect ground water recharge, marsh water levels, and erosion and sedimentation rates in wetlands. Temperature, winds, and solar radiation affect evaporation rates and drying. Increased wetness can expand wetland habitats, while drying and sedimentation can lead to plant succession and conversion of wetlands into terrestrial habitats. Substrate type and distribution (fine sediment, gravel, cobble, organic soil) is determined by water flow, decomposition, and past glaciation events.

Estuary and Nearshore Marine.-Substrate type and distribution is influenced by freshwater runoff, sediment load, tides, and wave action. Spits and barrier islands consist mostly of sand and clay derived from offshore shelf areas (McRoy, 1966). Eelgrass and seaweed meadows form in shallow, protected waters and are influenced by salinity, water temperature, water clarity, and water depth.

Eelgrass is an extremely productive community in the coastal marine habitat (Phillips and McRoy, 1980; Phillips, 1984). Eelgrass ecosystems promote vigorous nutrient and energy cycling by fixing nitrogen, absorbing nutrients from sediment, and producing carbon and other nutrients through detritus. Eelgrass beds can also act as carbon sinks when excess organic carbon is buried within the sediments (Duarte and others, 2005). Eelgrass provides extensive surface area for attachment or relatively quiet waters for bacteria, fungi, algae, and invertebrates. Eelgrass plants stabilize coastal habitats by reducing water flow and anchoring sediment. Eelgrass ecosystems act as nurseries for many fish and shellfish species, including salmon. Finally, eelgrass ecosystems provide abundant food resources for a number of wildlife species.

Migratory species can transfer nutrients, diseases, parasites, and seeds to and from different geographic areas as well as between different subsystems. Estuarine systems probably experience the greatest impact of these transfers due to the dense concentrations of waterfowl and shorebirds that stage in these lagoons every spring and fall. For example, the estuarine areas of Izembek NWR regularly host essentially the entire Pacific Flyway population of brant (Pacific Flyway Council, 2003), approximately 75\% of the Pacific Flyway population of Taverner's cackling goose (Branta hutchinsii ssp. taverneri)Ward and Stehn, 1989), a significant portion of the world population of emperor geese (Petersen and Gill, 1982), approximately 20,000-40,000 Steller's eiders (Polysticta stelleri) (unpub. data, Izembek NWR), and a number of other species during spring and/or fall migration. Individuals in these huge concentrations of migratory birds can come from different widely spaced geographic locations and provide links to these distant areas.

Habitats in this subsystem include kelp forests and seaweed meadows. At the interface between marine waters and terrestrial habitats is marine beach shore and dune meadows (beach rye grass, sandwort, and beach pea). Primary invertebrates in the marine system are benthic animals such as clams and crabs, invertebrates that live attached or amongst the eelgrass, and pelagic invertebrates like 
zooplankton and jellyfish. Primary consumers are invertebrates, fish, and waterfowl such as brant and Northern pintail. Secondary consumers include fish, sea stars, gray whales, sea otters, sea ducks, and seabirds. Top predators include killer whales (Orcinus orca), harbor seals (Phoca vitulina), Steller sea lions (Eumetopias jubatus), brown bears, and bald eagles. A number of migratory species use the nearshore marine waters, including sea ducks, seabirds, fur seals (Callorhinus ursinus), and gray whales (Eschrichtius robustus), providing links to other distant geographic areas. Pacific salmon transfer a considerable amount of marine nutrients into freshwater and terrestrial systems. Another important transfer of marine nutrients to terrestrial systems occurs through scavenging of marine-derived carcasses by terrestrial animals, especially marine mammal carcasses. Carcasses of gray whales and other marine animals wash ashore on a regular basis providing food for bald eagles, common ravens (Corvus spp.), brown bears, red foxes, and gray wolves (Canis lupus). Marine nutrients also are transferred into terrestrial and freshwater ecosystems when seabird, gulls, and terns bring food to their chicks.

\section{Drivers}

Coastal influences are one of the main ecosystem drivers for the estuarine and marine subsystems. Coastal influences include tides, coastal currents, upwelling and wind mixing, wave action, storm events, coastal erosion, salinity, water temperature, ice formation, and sea level. Tidal exchange and wind mixing with coastal wetlands, estuaries, and lagoons results in mixing of freshwater and saltwater and allows nutrient exchange between the marine and freshwater/terrestrial systems. Tides, coastal currents, wave action, and storm events can affect sediment disposition and coastal erosion. Freshwater and salt water mixing affects salinity, which influences species distributions.

The Pacific Ocean crustal plate descends under the North American plate at the Aleutian Islands and Alaska Peninsula, resulting in considerable tectonic and seismic activity. Tectonic activity caused the creation of the mountains in the Aleutian Range. Shishaldin and Pavlof Volcanoes, two of the most active volcanoes in the Aleutian Arc, occur on refuge lands. Volcanic eruptions can impact climate, introduce ash and chemicals into the atmosphere, and cause modification of existing landscapes and vegetation through lava flows, lahars, and ashfall. Earthquakes can also change landscapes through landslides, uplift, and subsidence. Tsunamis can modify coastline topography and habitats. These catastrophic events can also result in local extinctions of species.

Climate is an important ecosystem driver and impacts all five subsystems. Climatic factors affect physical processes such as water cycling, transportation of dust and pollen, and mixing of fresh and marine waters. Climatic factors affect biological processes such as vegetation community composition and structure, plant growth and reproduction, and distribution and survivorship of fauna. Climatic conditions can also operation on a local scale. For example, the climate can be quite distinct between the Pacific and Bering sides of the Alaska Peninsula and this in turn impacts the vegetation communities present on each side of the peninsula.

Another important ecosystem driver is anthropogenic effects. These include historical legacies as well as current and future impacts. Historical legacies include impacts from the Russian fur traders, the commercial fishing industry, World War II (WWII) development and occupation, and Cold War era development and occupation. Russian occupation of the area resulted in decimation of the sea otter population and the introduction of species (foxes [Vulpes vulpes], rats [Ratus norvegicus], ground squirrels [Spermopilus spp.]) on a number of islands. King Cove, False Pass, Sand Point, and several abandoned communities were established next to commercial fishing canneries or fish processing stations. The community of Cold Bay was established during WWII. At the height of the Aleutian campaign, more than 20,000 troops were stationed at Fort Randall, the large air base that was built on the present site of Cold Bay. During the Cold War era, DEW Line stations were constructed at Cold Bay 
and Cape Sarichef. The military occupation of the area has left the greatest impact on the landscape including the large airport runways, a myriad of roads and trails, abandoned buildings with lead paint and asbestos, buried contaminants and subsequent remediation sites, and the occasional unexploded ordinance. Additionally, the military planted a number of non-native Sitka spruce (Picea sitchensis) trees around the town of Cold Bay.

Anthropogenic effects of current and future concern include increased population levels adjacent to refuge lands, development, resource extraction, and pollution. Izembek NWR is particularly vulnerable to human impacts as the Cold Bay town site is surrounded by refuge lands, it has the only major all-weather airport in the area, and the FAA-approved flight path for aircraft using the airport crosses directly over Izembek Lagoon. Any development within the region that utilizes Cold Bay or its airport has the potential to impact the refuge. Development that could impact refuge lands includes expansion of transportation infrastructure such as roads or airport facilities, energy or mineral exploration/extraction and its associated infrastructure, commercial exploitation of natural resources, and residential development along refuge boundaries. Offshore oil and gas development or other commercial activities could lead to increased air and boat traffic at Cold Bay and adjacent communities with the increased risk of oil spills, noise pollution, aircraft overflights (especially helicopters), and other disturbances. Development of roads and other transportation infrastructure results in increased access and therefore a greater likelihood of habitat fragmentation and degradation, especially with unregulated use of off-road vehicles. Altered landscapes are slow to re-vegetate due to the cool maritime climate. Increased access may also be accompanied by overharvest or increased illegal harvest of natural resources. Human activities can result in the introduction of invasive species. Anthropogenic effects can also occur at a large scale. Marine debris and air-borne pollutants can travel thousands of miles. Disappearance or thinning of ice in the Arctic is likely to open the Northwest Passage and other previously iced over areas for transportation and resource extraction. This will increase shipping traffic along the coasts of the Alaska Peninsula and Unimak Island. The diverse and abundant wildlife within our refuge lands are particularly vulnerable to disturbance because they are concentrated within a small geographic area and care must be taken to ensure that ecosystems remain healthy.

\section{Potential Effects of Contemporary Climate Change}

One of the biggest changes in ecosystems, now and in the future, is global climate change effects. Rising temperatures could result in drying of some lakes and wetlands, increased melting of glaciers, decreased snow pack, increased runoff, and changes in freeze-thaw dynamics. There will likely be changes in weather patterns, including changes in frequency and intensity of storms. Changes in water temperature, salinity, water clarity, $\mathrm{pH}$, and water depth will impact freshwater, estuarine, and marine communities, particularly eelgrass/seaweed ecosystems and salmon populations. Although global sea level is likely to rise, it will be offset to some extent in our region by isostatic rebound from the last glacial period.

Climate change will impact plant and animal communities. Changes may occur in phenology, abundance, and species distribution and there is likely to be an increase in the abundance of insect pests, parasites, and diseases. Northern species at the edge of their range, such as caribou, may experience the greatest impacts, while other species, such as moose (Alces alces), may benefit from expansion of shrub communities. Brown bears and arctic ground squirrels may experience changes in timing and duration of denning and hibernation. Milder winters will likely result in an increase in the numbers of overwintering birds. We are already experiencing increasing numbers of overwintering brant (Ward and others, 2009). Long-distance migrants, however, use photoperiod as the cue for timing of migration so could experience a trophic mismatch between the onset of their breeding activities and changes in plant 
and insect phenology on their breeding grounds. Some species may be resilient and adapt to changes, while others may go extinct or shift their ranges.

\section{References}

Duarte, C.M., J. Middleburg, and N. Caraco. 2005. Major role of marine vegetation on the oceanic carbon cycle. Biogeosciences 2:1-8.

McRoy, C. P. 1966. The standing stock and ecology of eelgrass (Zostera marina L.) in Izembek Lagoon, Alaska. M.S. Thesis, University of Washington.

McRoy, C.P. 1968. The distribution and biogeography of Zostera marina (eelgrass) in Alaska. Pacific Science 22(4): 507-514.

Pacific Flyway Council. 2003. Pacific flyway management plan for the Pacific population of brant. U.S. Fish and Wildlife Service, Portland, Oregon, unpublished report.

Petersen, M. R and R. E. Gill, Jr. 1982. Population and status of Emperor Geese along the north side of the Alaska Peninsula. Wildfowl 33:31-38.

Phillips, R. C. 1984. The ecology of eelgrass meadows in the Pacific Northwest: a community profile. USFWS, FWS/OBS-84/24.

Phillips, R. C. and C. P. McRoy (eds). 1980. Handbook of Seagrass Biology: An Ecosystem Perspective. Garland Publishing, Incorporated.

Talbot, S. S, S. L. Talbot, and W. B. Schofield. 2006. Vascular flora of Izembek National Wildlife Refuge, Westernmost Alaska Peninsula, Alaska. Rhodora 108 (935): 249-293.

Ward, D. H., C. P. Dau, T. L. Tibbitts, J. S. Sedinger, B. A. Anderson, and J. E. Hines. 2009. Change in abundance of Pacific Brant wintering in Alaska: evidence of a climate warming effect? Arctic 62:301311.

Ward, D.H. and R.A. Stehn. 1989. Response of Brant and Canada geese to aircraft disturbance at Izembek Lagoon, Alaska. Final Report, USFWS, Alaska Fish and Wildlife Research Center, Anchorage, AK.

Ward, D.H., C.J. Markon and D.C. Douglas. 1997. Distribution and stability of eelgrass beds at Izembek Lagoon, Alaska. Aquatic Botany 58: 229-240. 


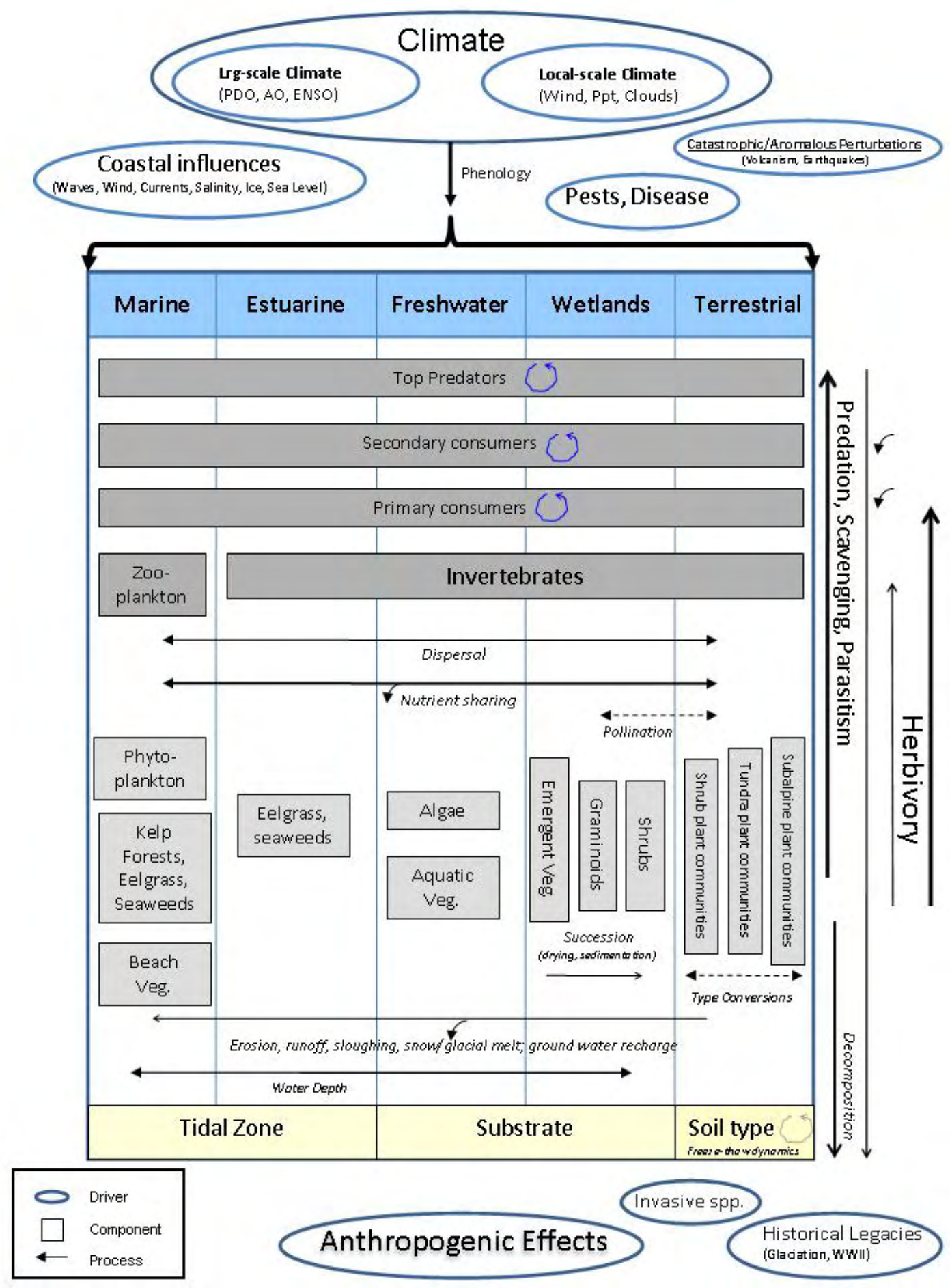

Figure A13.1. Conceptual model of Izembek NWR. 
118 Conceptual Ecological Models, Alaska National Wildlife Refuges

This page left intentionally blank 


\section{Appendix 14. NORTH PACIFIC COAST ECOREGION-Kodiak NWR}

By Bill Pyle, Supervisory Biologist, Kodiak NWR

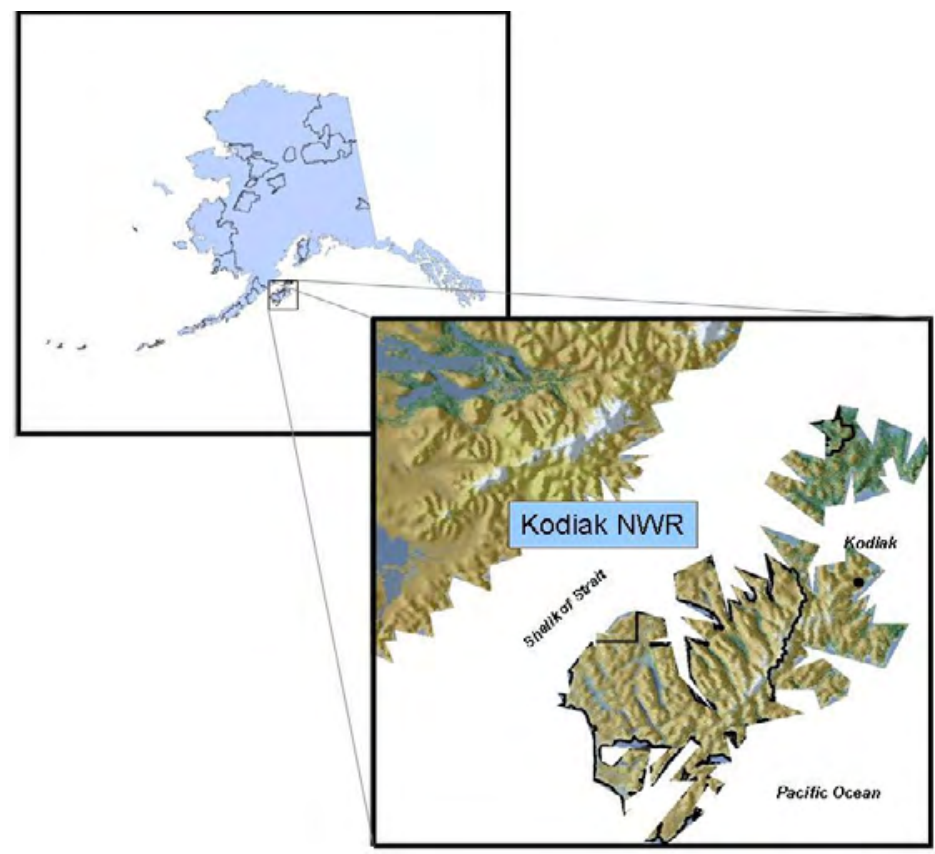

\section{Geographic Context}

Kodiak Island, the second largest island in the U.S., is part of the Kodiak Archipelago in southcentral Alaska. The island is located in the northern Gulf of Alaska, approximately $48 \mathrm{~km}$ (30 miles) offshore of mainland Alaska. Terrain of the 7,284 km² (1.8 million-acre) Kodiak Refuge on Kodiak Island is characterized by mountains (to 1,360 m [4,460 ft] elevation), small remnant alpine glaciers, a few large lakes, many small lakes and wetlands, an abundance of rivers, and many long fjords.

\section{Climate}

Kodiak NWR experiences a subarctic maritime climate. Precipitation patterns consist of a relatively even distribution throughout the year; snow above $150 \mathrm{~m}$ (492 ft) elevation between November and February; and a pronounced rain-shadow effect on the lee side of the primary SW-NE trending mountain chain. The city of Kodiak receives an average of $191 \mathrm{~cm}$ precipitation annually, and an annual average snowfall of $183 \mathrm{~cm}$ (Shulski and Wendler, 2007). Year-round average temperature in Kodiak is $5^{\circ} \mathrm{C}$, but high temperature averages $16^{\circ} \mathrm{C}$ in August and low temperature averages $-4^{\circ} \mathrm{C}$ in January. Kodiak averages 131 days/yr below freezing, and 44 rainy days in summer; prevailing northwest winds average $4 \mathrm{~m} / \mathrm{s}$, across the year (Shulski and Wendler, 2007). 


\section{Abiotic Components}

Primary components include parent material-soil, natural disturbance, and previously described physiography and climate. Although geology of the Kodiak Archipelago is quite diverse, a few types-namely sedimentary wacke-shale, intrusive granitics, and rocks associated with unconsolidated glacial deposits - dominate the area and consequently serve as the foundation of soil parent material (Wilson and others, 2005). Due to its proximity to volcanoes of the Alaska Peninsula, volcanic ash periodically falls on the area and comprises another locally important soil constituent (Griggs, 1915). Soils have not been inventoried in most of the archipelago, including in the Refuge area. It is likely that soil composition is quite diverse in correspondence with inherent variation in parent material and physiography.

Natural disturbances can exert a prominent influence on ecosystem function and structure. The Kodiak region is influenced by relatively few disturbances. With the exception of periodic earthquakes and ashfalls, disturbance tends to be limited primarily to flooding of rivers and tidelands and avalanches in the mountains.

In general, most of the abiotic processes highlighted in the ecosystem model operate throughout Alaska. What probably differs among regions including Kodiak are the properties of the process and the rate at which it operates, as modified by regional and local factors (climate, physiography, etc). In the mountains of Kodiak Island, erosion and leaching of inorganic compounds are likely prominent due to high relief and moderate rainfall. Proximity to the ocean not only modifies climate but also probably influences the type and rate of deposition of inorganic compounds, most basically salt, in precipitation.

\section{Biotic Components}

The area supports a diversity of land cover types indicative of ocean influence, high relief, and topographic, precipitation, and hydrologic gradients. Dominant land cover in Kodiak uplands, like that found in the adjacent Alaska Peninsula, is composed of grassland and deciduous shrub-tree types that

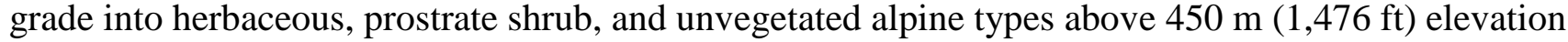
(Fleming and Spencer, 2006). Extensive forest of balsam poplar (Populus basamifera) occurs along major rivers and sedge flats in estuaries. Land cover on the south end of the Refuge includes extensive area of grassland, wet tundra, and dry tundra - types similar to those found in western Alaska. The archipelago, including Kodiak Island, has been described as a distinct Alaskan ecoregion based primarily on its island geography, size, geological history, land cover composition, and insular fauna (Nowacki and others, 2001).

Periodic Pleistocene ice-ages inundated and scoured most of the central Alaskan coast including all of Kodiak Island except for a 1,620 ha (400,309 acres) ice-free area (refugium) at the southwestern end (Mann and Peteet, 1994). Consequently, glaciation, coupled with island size and location, shaped the island's flora and fauna as indicated by the apparent absence of endemic vascular plants and animals, and by the depauperate native mammal fauna (Karlstrom and Ball, 1969; Parker, 2006). Immediately prior to Euro-American settlement, only 6 native mammal taxa probably occurred (brown bear [Ursus acrtos], red fox [Vulpes vulpes], ermine [Mustela ermine], tundra vole [Microtus oeconomus], river otter [Lontra canadensis], little brown bat [Myotis lucifugus]). Between 1920 and 1960, several non-native herbivores--including Sitka black-tailed deer (Odocoileus hemionus sitchensis), mountain goat (Oreamnos americanus), snowshoe hare (Lepus americanus), beaver (Castor canadensis), and red squirrel (Tamiasciurus hudsonicus)--were successfully introduced (U.S. Fish and Wildlife Service, 2007). Anadromous salmonids are an important component of the ecosystem, both prehistorically and presently. Salmonids that spawn and rear on the Refuge are considered a key food of brown bears and eagles (Haliaeetus leucocephalus), they play an important role in the aquatic-terrestrial nutrient cycle, 
and they provide for substantial subsistence, recreational, and commercial harvest (U.S. Fish and Wildlife Service, 2007).

\section{Ecosystem Drivers}

The ecosystem model for Kodiak Refuge (fig. A14.1) was structured into five major systems (atmospheric, terrestrial, lacustrine, riverine, and nearshore marine) due to the substantial differences among system components (e.g., aquatic vs. terrestrial) and processes (physical vs. biological). All five systems are linked via movement and cycling of matter (e.g., marine-derived carbon incorporated into tissue of brown bear) and energy (e.g., ocean-mediated climate and growing season) through air, water, and organisms. The linkage among systems is further illustrated by overlap between systems, such as occurs in estuaries, riparian, and intertidal wetlands. Ecosystem components, consisting of managementfeatured organisms and taxonomic groups of organisms, are arrayed within trophic levels. Major physical and biophysical processes are identified within and surrounding the atmospheric and terrestrial systems. Arrows indicate location and direction of interaction between components and processes within and between systems. Due to space limitations, primary components and functional processes are emphasized for atmospheric and terrestrial systems.

An initial assessment suggested that climate, salmon, and plant production were primary drivers of the Kodiak ecosystem of relevance to refuge management (Heglund, 2002). As with other regions, climate largely determines the type and rate of matter and energy movement in terrestrial systems, and it often is a key determinant of biological capacity (e.g., productivity, diversity). Salmon are thought to play an important role in nutrient cycling, in addition to their role in the economy of brown bear and humans. Carbon incorporated in salmon at sea is imported then deposited in lakes and rivers after the salmon die, and in adjacent riparian areas and uplands after salmon are preyed upon by brown bear. Plant production across all systems is considered a driver because it is a primary locally-produced source of carbon, energy, and nutrients. Additionally, plants build soil, protect it from erosion, and provide seasonal food to a diversity of taxa ranging from insects through brown bear to non-native Sitka black-tailed deer. The role, importance, and future influence of these three drivers, as well as others (e.g., non-native herbivores), need further evaluation.

\section{Potential Effects of Climate Change}

No systematic and comprehensive search of technical reports was conducted and none of the reviewed reports and publications on file at the Refuge described expected effects of climate change in the vicinity of the Kodiak Archipelago. Consequently, the following discussion reflects the perspective, speculation, and selected priority concerns of the author regarding potential effects. Most of these forecasted effects and outcomes are expected to be widely manifested and measurable at multiple scales ranging from the level of individual watershed $\left(>50 \mathrm{~km}^{2}\right)$ to the entire archipelago $\left(13,000 \mathrm{~km}^{2}\right)$.

Increasing mean winter temperature will influence quality and quantity of freshwater aquatic habitat available to salmonids. In particular, the volume of snowpack will decline, which will lead to a reduction in riverine discharge in summer and capacity of aquatic habitat to support spawning and rearing salmonids. Over the long-term, 50-100 years, it is likely that ocean acidification will reach a threshold that triggers substantial changes in quality of marine habitat to salmonids, particularly the availability of preferred forage fish. Cumulative effects of changes in freshwater and marine habitats will ultimately lead to substantial reductions in salmonid abundance and, in turn, the availability of salmon for subsistence, recreational, and commercial harvest. 


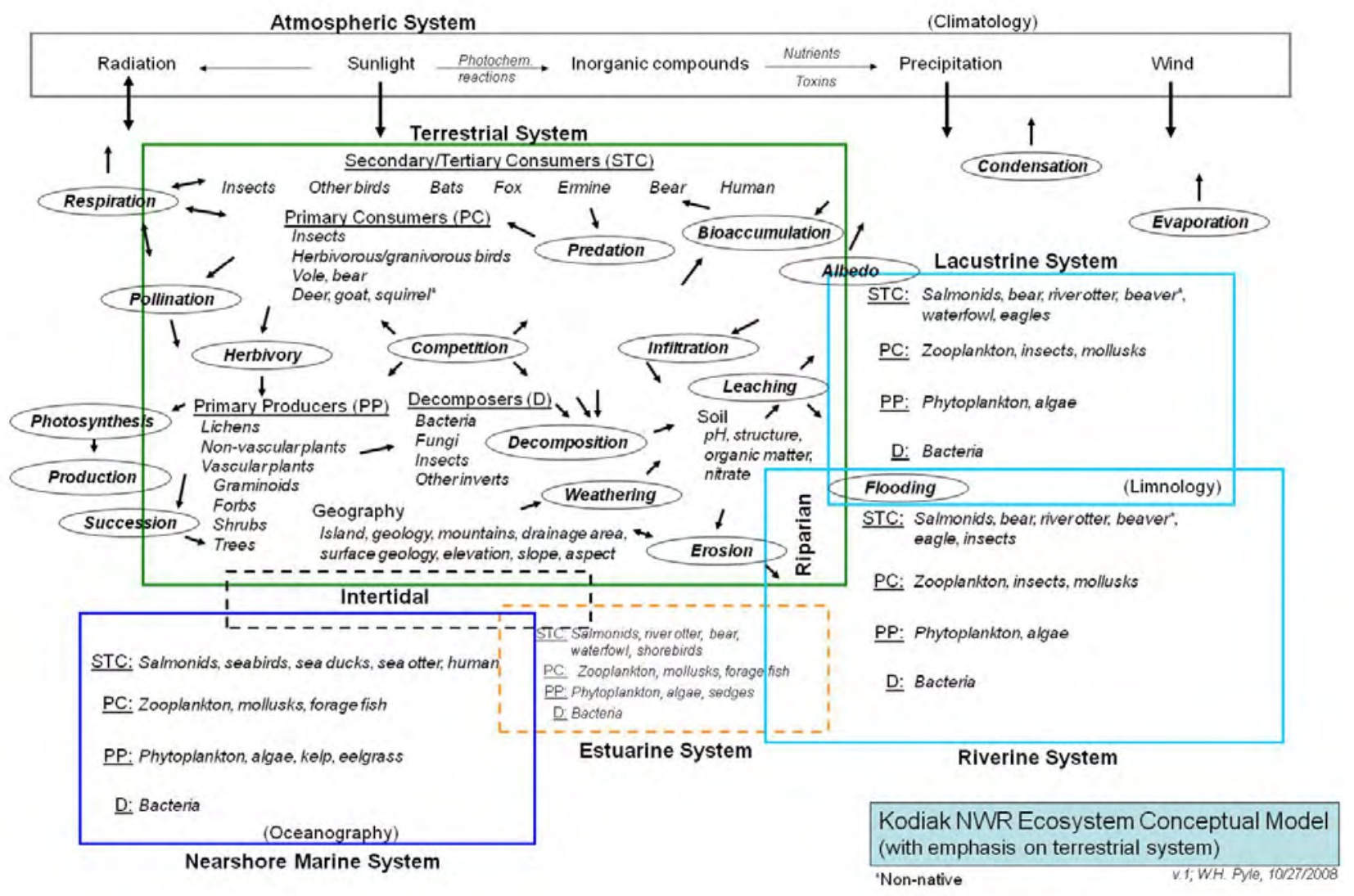

Figure A14.1. Conceptual model of Kodiak NWR. Ecosystem components and processes expected by managers to respond most dramatically to contemporary climate change are in red text or arrows; pink color represents expectation of intermediate levels of response to climate change.

Increasing mean winter temperature coupled with change in snowpack will influence vegetation composition. Specifically, composition is expected to increasingly favor species adapted to moderate temperatures and warmer soils and to disfavor species adapted to short-growing seasons and cold soils (e.g., alpine plants). Though compositional changes will likely involve all species, changes will be most apparent for species that dominate land cover and that are distributed across an elevation gradient. For example, distribution of Sitka alder (Alnus sitchensis), a common shrub species and primary cover type, is expected to expand upslope. Correspondingly, heath (Empetrum nigrum) communities are expected to contract from the current lower elevation limit and to expand into higher elevations covered currently by rock and late-lying snow. At the same time, increasingly temperate conditions will potentially favor upslope expansion of existing invasive plant species, as well as the establishment and propagation of new invasive plant species whose establishment and growth is favored by temperate climatic conditions. 
Increase in $\mathrm{CO}_{2}$ level is expected to induce many changes to abiotic processes. It seems likely that direction of change may be readily predicted for several important processes (e.g., increased air temperature, reduced ocean $\mathrm{pH}$ ), although there is great uncertainty of the potential rate and magnitude of change. In some cases, there is high uncertainty about the entire nature of change (e.g., seasonal precipitation distribution and pattern).

Potential effects of greatest concern pertain to brown bear and introduced non-native ungulates (Sitka black-tailed deer, mountain goat, and Roosevelt elk [Cervus canadensis roosevelti]). Increase in mean winter temperature will reduce the frequency of severe winter weather (e.g., deep and persistent snow, subfreezing temperatures, high winds). Although such severe weather has historically influenced seasonal distribution and abundance of all ungulates, it is apparently the primary factor that has regulated the size of Sitka black-tailed deer populations. Increased over-winter survival of deer coupled with expansion of area of winter range (formerly transition range and lower limit of summer range) will initially foster a large increase in the size of the Sitka black-tailed deer population (e.g., possibly up to one million deer on Kodiak Island). Eventually the population will exceed the carrying capacity of habitat, decline in abundance, and sustain itself at a lower level on habitat whose capacity is substantially diminished. Although the increase in Sitka black-tailed deer will provide additional food to brown bear, the net effect of the deer increase will be a significant reduction in the quality of brown bear habitat and, ultimately, the productivity of the bear population. Specifically, excessive Sitka black-tailed deer herbivory is expected to substantially reduce abundance of plant species preferred by deer. Some of these, such as red elderberry (Sambucus racemosa), also are preferred by brown bear to an extent that when the berries are ripe, animals will allocate more time to foraging on berries than to salmon. Sufficient seasonal intake of red elderberries is suspected to foster optimum physical condition of bears. Combined with other effects, such as diminished salmon abundance, the bear population will likely decline, and thus exert less influence on the ecosystem and provide fewer opportunities for wildlife observation and hunting. It is unknown whether climate change will increase the potential for inadvertent introduction of pathogens that could impair bear survival. Genetic research indicates that the bears of Kodiak are potentially very vulnerable to non-native pathogens due to exceptionally limited genetic diversity, including genes thought to contribute to immune response (Talbot and others, 2006).

\section{References}

Fleming, M. and P. Spencer. 2006. Habitat mapping of the Kodiak Archipelago. Digital data files, maps, and user’s guide. Alaska Science Center, U.S. Geological Survey, Anchorage, Alaska.

Griggs, R.F. 1915. The effect of the eruption of Katmai on land vegetation. Bulletin American Geographical Society 47:193-203.

Heglund, P.J. 2002. Recommendations and transcript [from the] Kodiak National Wildlife Refuge

Fisheries, Wildlife, and Habitat Management Workshop. Unpubl. Report. Kodiak, AK: 80pp.

Karlstrom, T. N. V., and G. E. Ball (eds.). 1969. The Kodiak Island Refugium: Its Geology, Flora,

Fauna, and History. The Boreal Institute, University of Alberta. The Reyerson Press, Toronto, Canada. 262 pp.

Mann, D.H. and Peteet, D.M. 1994. Extent and timing of the last glacial maximum in southwestern Alaska. Quarternary Research 42:136-148.

Nowacki, G., P. Spencer, T. Brock, M. Fleming, and T. Jorgenson. 2001. Ecogregions of Alaska and neighboring territories. U.S. Geol. Surv., Reston, VA.

Parker, C. L. 2006. Vascular plant inventory of the Kodiak Late Glacial Refugium, Kodiak Island, Alaska. Unpubl. report on files with Kodiak NWR, Kodiak, AK. 41pp. 
Talbot, S. S, S. L. Talbot, and W. B. Schofield. 2006. Vascular flora of Izembek National Wildlife Refuge, Westernmost Alaska Peninsula, Alaska. Rhodora 108 (935): 249-293.

Shulski, M. and G. Wendler. 2007. The Climate of Alaska. University of Alaska Press, Fairbanks. 216 pp.

USFWS. 2007. Final comprehensive conservation plan and environmental impact statement [for] Kodiak National Wildlife Refuge.U.S. Fish \& Wildlife Service, Anchorage, AK.

Wilson, F. H., Labay, K.A., Mojadjer, S., and Shew, N. 2005. Digital datasets for geologic map by Wilson, F.H.: preliminary integrated map databases for the United States: Digital data for the reconnaissance geologic map for the Kodiak Islands, Alaska: U.S. Geological Survey Open-File Report 2005-1340. 


\section{Appendix 15. Beaufort-Chukchi Seas Marine Model}

\section{Geographic Context}

Marine areas bordering the Polar Ecoregion include the Chukchi and Beaufort Seas of the Arctic Ocean. The Chukchi Sea is a small southern extension of the Arctic Ocean that spans the gap between the U.S. and Russia from Barrow to Wrangell Island and south to the Bering Strait, including Kotzebue Sound. The Beaufort Sea is the portion of the Arctic Ocean north of the Northwest and Yukon Territories of Canada, and Alaska between Barrow and Canada. This area corresponds with the Chukchi and Beaufort Seas PBCR (fig. 8) and marine ecoregions 24 through 30 of Piatt and Springer (2007; table 3). Both Seas are ice covered for most of the year with possible navigable openings August through October. Multiple rivers feed these seas, notably the MacKenzie River in Canada and the Colville and Kobuk Rivers in Alaska. The system is depicted in figure A15.1.

Arctic NWR borders the Beaufort Sea; Selawik NWR borders the Chukchi Sea in Kotzebue Sound; and the Chukchi Sea Unit of Alaska Maritime NWR borders the Chuckchi Sea near Point Hope.

\section{Climate Overview}

The Chukchi and Beaufort Seas experience Arctic weather as described for the Polar Ecoregion. In summary, it includes cold, stormy winter and cloudy but milder summers. Sea ice has a close relationship with weather (Shulski and Wendler, 2007). In particular, ice-cover on oceans greatly reduces the usual moderating influence of the maritime environment on climate. A semi-permanent high-pressure system over the pole drives counter-clockwise wind and water circulation in the Arctic Ocean.

\section{Abiotic Processes and Components}

The Beaufort Sea has a relatively narrow shelf ( $<85 \mathrm{mi}$ ), especially north of Alaska, while the Chukchi Sea is uniformly shallow, with the majority less than $50 \mathrm{~m}$ deep. Ocean circulation includes currents flowing north from the Pacific through the Bering Strait, which then continue north or curve to the east along the Alaskan Coast. Further north in the Arctic Ocean, the Beaufort Gyre circulates counter-clockwise. Most water exits the Arctic Ocean by flowing into the Atlantic Ocean.

The extent, distribution, timing and thickness of shorefast and sea ice are the foundation of the polar marine ecoregion. The amount and distribution of sea ice depends on complex relationships among air temperature, sea temperature, salinity, and ocean-circulation patterns (Carmack and MacDonald, 2002), all of which reflect global climate. Individually, each of these variables also has a complex relationship with climate. For example, salinity alone responds to river run-off from land; the balances between evaporation and precipitation over the ocean; and the influx of lower-salinity water from the Bering Strait.

Chemical and physical properties of marine water also directly affect marine organisms, thereby structuring the marine ecosystem (MacDonald and others, 1999). Specifically, ice distribution and the amount and timing of terrestrial runoff affect the stratification, turbidity, salinity and nutrient content of marine water, which affect light and nutrient resources available for primary productivity. Ice and water also affect the geomorphology of coastal and nearshore areas by determining the extent of coastal erosion, ice scour and sediment deposition and transport. These three processes are the dominate determinants of the quality of benthic and coast habitats of the Beaufort Sea (Carmack and MacDonald, 2002). 


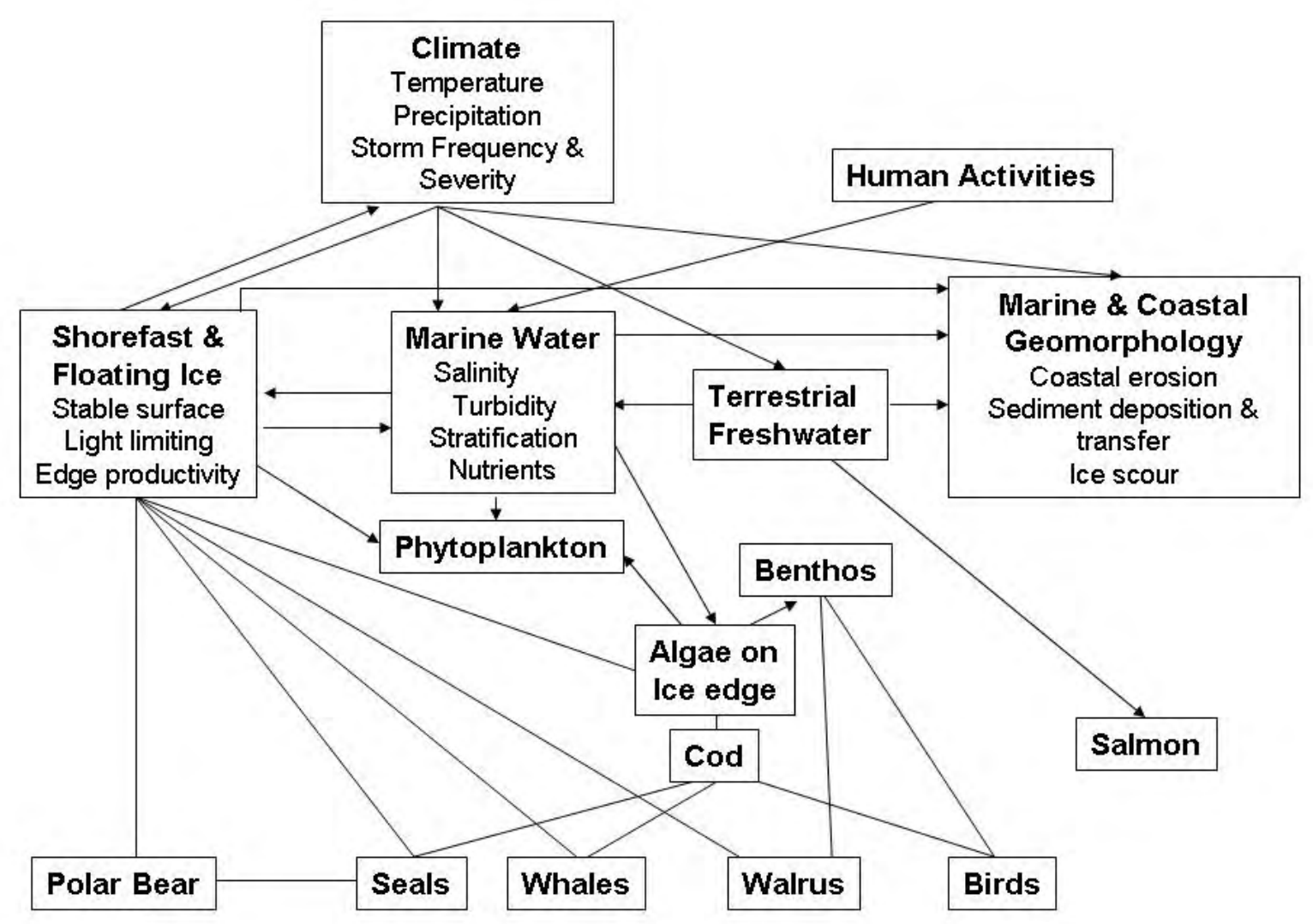

Figure A15.1. Conceptual model of the Polar Marine ecosystem illustrating relationships among system drivers, habitat properties, and selected biotic components.

\section{Biotic Processes and Components}

Shorefast and sea ice provide habitat for polar bears, seals and walruses (Tynan and DeMaster, 1997). Specific needs vary by species, life stage and time of year. For example, polar bear (Ursus maritimus) females and cubs frequent landfast ice whereas individuals of other ages and genders use sea ice for seal hunting and denning. Ringed seals (Phoca hispida) prefer landfast ice, and only for pupping and resting, whereas bearded seals (Erignathus barbatus) and walruses (Odobenus rosmarus divergens) prefer thin, shifting ice in relative shallow water, as long as the ice can support their weight (Tynan and DeMaster, 1997). Gray whales (Eschrichtius robustus) frequent areas with low ice cover, bowhead whales (Balaena mysticetus) prefer moderate ice cover, and belugas (Delphinapterus leucas) prefer moderate to high ice cover. In addition, beluga whales frequent ice edges and cracks (Moore and others, 2000). Patterns of whale distribution relative to ice reflect the linkage with prey availability. Because some of the marine mammals are migratory, the timing of ice availability and quality relative to animal movements is important (Bradstreet, 1982; Tynan and DeMaster, 1997). 
Ice cover also influences primary productivity. Phytoplankton abundance is limited in the Arctic by ice that obstructs light penetration as well as by the deficiency of nutrients in high-latitude marine waters. An important source of primary productivity is algal growth, which occurs on the underside of the edges of shorefast ice. The copepods and other organisms living in algal mats are consumed by cod, which support many marine mammal populations. Algae also fuel benthic production when they slough from the bottom of the ice as it melts. Benthic organisms, in turn, are important food sources for bird species. Algal blooms may also foster what phytoplankton growth does occur, which tends to peak six weeks after algal growth (Gosselin and others, 1985).

A large part of the production in the Chukchi Sea is actually transported there through the Bering Strait and originates on the Bering Shelf Edge. It is this massive infusion of nutrients and zooplankton carried by the Anadyr current that creates some of the highest marine primary productivity in the world (Piatt and Springer, 2003).

\section{References}

Bradstreet, M. S. W. 1982. Occurrence, habitat use, and behavior of seabirds, marine mammals, and arctic cod at the Pond Inlet ice edge. Arctic 35:28-40.

Carmack, E.C. and R. W. MacDonald. 2002. Oceanography of the Beaufort Sea: a setting for marine life. Arctic 55:29-45.

Gosselin, M. L. Legendre, S. Demers, and R. G. Ingram. 1985. Responses of sea-ice microalgae to climatic and fortnightly tidal energy inputs (Manitounuk Sound, Hudson Bay). Canadian Journal of Fisheries and Aquatic Sciences 42:999-1006.

MacDonald, R. W., E. C. Carmack, F. A. McLaughlin, K. K. Faulkner, and J. H. Swift. 1999. Connections among ice, runoff and atmospheric forcing in the Beaufort Gyre. Geophysical Research Letters 26:2223-2226.

Moore, S. E., D. P. DeMaster, and P. K. Dayton. 2000. Cetacean habitat selection in the Alaskan Arctic during summer and autumn. Arctic 53:432-447.

Piatt, J.F. and A.M. Springer. 2003. Advection, pelagic food webs, and the biogeography of seabirds in Beringia. Marine Ornithology 31:141-154.

Piatt, J.F. and A.M. Springer. 2007. Marine ecoregions of Alaska. Pp. 522-526 in: Spies, R.B. Longterm ecological change in the northern Gulf of Alaska. Elsevier B.V., Oxford, UK.

Shulski, M. and G. Wendler. 2007. The Climate of Alaska. University of Alaska Press, Fairbanks. 216 pp.

Tynan, C. T., and D. P. DeMaster. 1997. Observations and predictions of Arctic climatic change: potential effects on marine mammals. Arctic 50:308-322. 
This page left intentionally blank 


\section{Appendix 16. Bering Sea Marine Model}

\section{Geographic Context}

The Bering Coast Ecoregion is associated with the East Bering Sea, which extends from the Alaska Peninsula and Aleutian Islands to the Bering Strait. This area corresponds to marine ecoregions 21 through 24 of Piatt and Springer (2007; table 3) and is a subset of the Eastern Bering Sea PBCR (fig. 8). Freshwater input comes from the Yukon, Kuskokwim, Nushagak, and Kobuk Rivers as well as a number of smaller ones.

Yukon Delta, Togiak, Selawik NWRs and the Bering Sea Unit of Alaska Maritime NWR border or are surrounded by the eastern Bering Sea and the Aleutian Islands Unit of Alaska Maritime NWR forms the boundary between the Bering Sea and the North Pacific Ocean. Both Yukon Delta and Togiak NWRs include coastal, intertidal and off-shore areas in their boundaries. Specifically, Yukon Delta includes an approximately $25 \mathrm{~km}$ ring around Nunivak Island and Togiak includes up to $8 \mathrm{~km}$ off Capes Newnham and Peirce. These areas fall mostly in the Eastern Bering Sea-Inner Domain and slightly in the Eastern Bering Sea-Middle Domain marine ecoregions (Piatt and Springer, 2007). In these areas, the refuges have jurisdiction over bottom habitat and anything permanently attached, while the National Marine Fisheries Service is responsible for mobile organisms.

\section{Climate Overview}

Summer weather typically includes long days, high insolation and benign winds associated with a weak Aleutian Low pressure system. The Aleutian Low is stronger in the winter, resulting in strong, cold winds from the northeast and frequent storms (Overland, 1981).

\section{Abiotic Processes and Components}

Physiography, climate and water transport drive the East Bering Sea marine ecoregion (fig. A16.1). Physiographically, the eastern Bering Sea is characterized by a broad ( $>500 \mathrm{~km})$ continental shelf consisting of three domains that can be described by depth ranges (i.e., coastal, < $50 \mathrm{~m}$ deep; middle shelf, 50 to $100 \mathrm{~m}$ deep; outer shelf, 100-200 m deep) and a much deeper basin to the west (>350 m deep, Stabeno and others, 2001). However, Piatt and Springer (2007; fig. 7) divide the coastal domain into a coastal and an inner domain; the coastal part is defined by low-salinity Alaska Coastal Current water closer to shore. Water circulation is driven by northward currents, tidal flow, and vertical mixing due to wind (Stabeno and others, 1999, 2008). The interactions among these factors (including ice) determine water stratification, ice dynamics, and water temperature, which in turn drive productivity and structure of the food web (Napp and Hunt, 2001).

Ice borders the west coast of Alaska in winter, extending a greater distance from shore in the north than the south (Shulski and Wendler, 2007). Ice cover shows greater interannual variability in this region, especially in the southern area (Hunt and others, 2002), compared with the Arctic Ocean where ice is nearly perennial and the north Pacific where it does not form.

Closer to shore, freshwater delivery from inland rivers into the marine environment is important because the marine environment is very shallow (Buckley and others, 2009). Consequently, this allows freshwater lenses to reach far into the ocean where they feed into the freshwater-driven Alaska Coastal Current that originates in the Gulf of Alaska and eventually enters the Chukchi Sea. Freshwater creates stratification, water column stability, enhanced heating by sun, and therefore a band of productive, low salinity, warm water hugging the entire Bering Sea coast. 


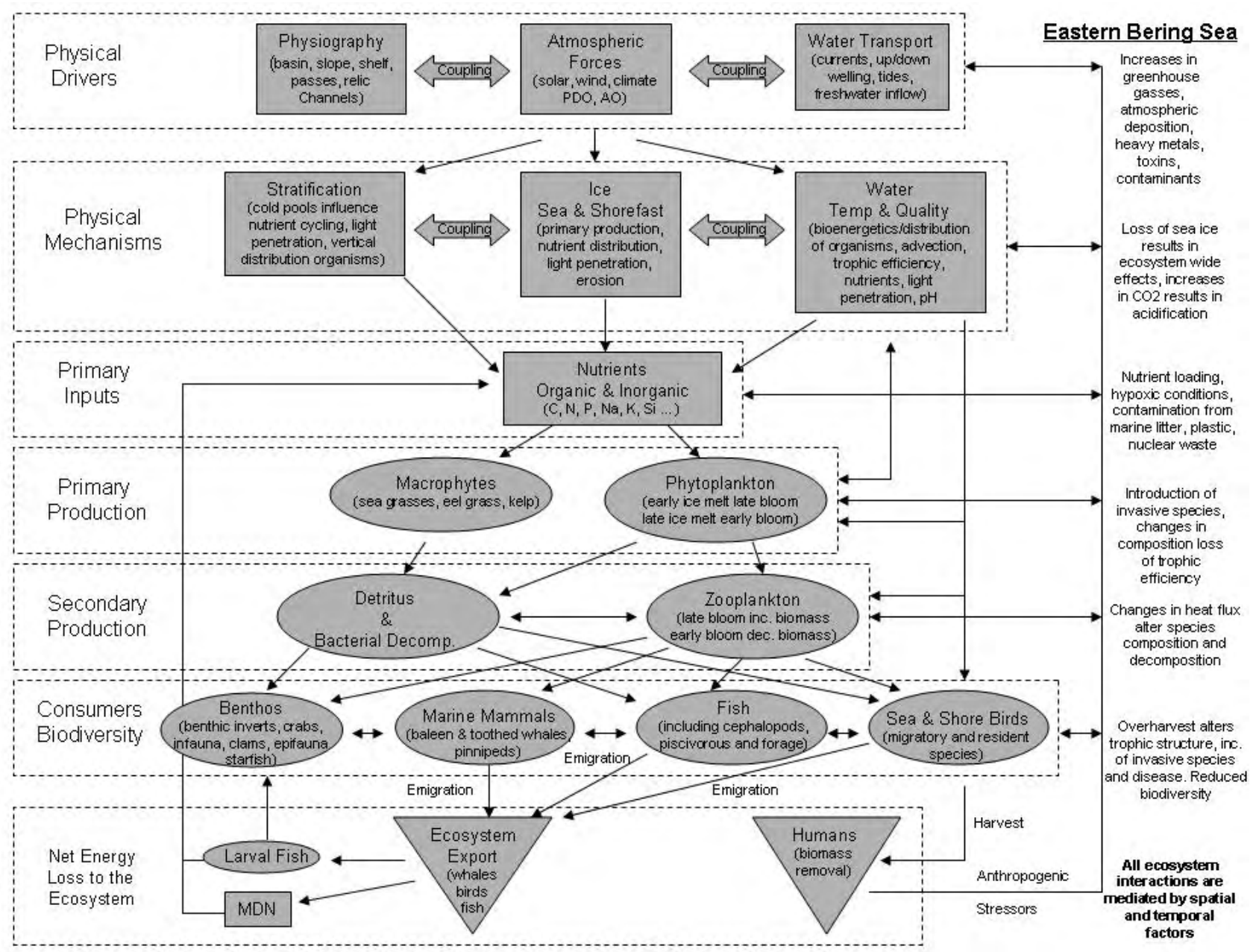

Figure A16.1. Conceptual model of East Bering Sea (provided by staff of Togiak NWR).

\section{Biotic Processes and Components}

The Bering Sea is one of the world's most productive ecosystems (Walsh and others, 1989), especially the middle shelf and outer shelf domains (Springer and others, 1996). Primary production begins each spring with a bloom of phytoplankton (Niebauer and others, 1995). Current hypotheses suggest that if there is a late ice retreat (March or later), the water will be calm and cold when there is sufficient light for growth (Hunt and others, 2002). However, zooplankton are limited by the cold water, so phytoplankton will fall to the bottom rather than be consumed (Hunt and others, 2002). In this scenario, the benthic community will be supported as will the productivity of larval and juvenile fish, and predatory fish. In theory, this may reduce the competition between piscivorous birds and marine mammals versus predatory fish, creating better conditions for the birds and mammals. On the other hand, if there is no ice or early ice retreat (before mid-March), the bloom of phytoplankton will be delayed until less wind and calmer waters prevail in May or June. In this case, water will be warmer and more favorable for zooplankton, which fuel fish populations. Under these speculative scenarios, the greater competition between predatory fish versus northern fur seals (Callorhinus ursinus), kittiwakes 
(Rissa spp.) and other birds and marine mammals for forage fish may explain the decline of piscivorous birds and mammals in the Bering Sea since warmer conditions began in the mid-1970s (National Marine Fisheries Service, 1993, 1995; Withrow and Loughlin, 1995; Hunt and Byrd, 1999). Because many species in the Bering Sea food web are important commercially or for subsistence needs, harvest must be managed with these dynamics in mind for all ecological services to be maintained.

In nearshore areas, biotas and habitats that are of particular concern to managers are eelgrass (Zostera spp.) and kelp beds. These areas provide habitat for benthos, marine mammals, migratory and resident fishes and birds, including many species important in sport and commercial fisheries (Dean and others, 2000), and are vulnerable to human disturbance (North Pacific Fishery Management Council, 2002). Eelgrass occurs in protected bays and inlets with freshwater influence, whereas kelp is more oceanic. Both are affected by freshwater lenses created by runoff from inland rivers.

\section{References}

Buckley, T. W., A. Greig, and J. L. Boldt. 2009. Describing summer pelagic habitat over the continental shelf in the eastern Bering Sea, 1982-2006. NOAA Technical Memorandum NMFS-AFSC-196. U.S. Department of Commerce.

Calif.: ESRI Press.

Dean, T.A., L. Haldorson, D.R. Laur, S.C. Jewett, and A. Blanchard. 2000. The distribution of nearshore fishes in kelp and eelgrass communities in Prince William Sound, Alaska: associations with vegetation and physical habitat characteristics. Environmental Biology Fisheries 57:271-287.

Hunt, G. L. and G. V. Byrd Jr. 1999. Marine bird populations and carrying capacity of the eastern Bering Sea. In: Loughlin, T. R., Ohtani, K. (eds.), Dynamics of the Bering Sea. University of Alaska Sea Grant, Fairbanks, Alaska.

Hunt, G. L., P. Stabeno, G. Walters, E. Sinclair, R. D. Brodeur, J. M. Napp, and N. A Bond. 2002. Climate change and control of the southeastern Bering Sea pelagic ecosystem. Deep-Sea Research II 49:5821-5853.

Napp, J. M. and G. L. Hunt. 2001. Anomalous conditions in the south-eastern Bering Sea, 1997: linkages among climate, weather, ocean and biology. Fisheries Oceanography 10:61-68.

Niebauer, H. J., V. Alexander, and S. M. Henrichs. 1995. A time-series study of the spring bloom at the Bering Sea ice edge I: physical processes, chlorophyll and nutrient chemistry. Continental Shelf Research 15:1859-1878.

National Marine Fisheries Service. 1993. Final conservation plan for the northern fur seal (Callorhinus ursinus). Prepared by the NMFS/Alaska Fisheries Science Center/National Marine Mammal Laboratory, Seattle, WA and the NMFS/Office of Protected Resources, Silver Spring, MD. 80 pp.

National Marine Fisheries Service. 1995. Status review of the United States Steller sea lion (Eumetopias jubatus) population. Prepared by the NMFS/Alaska Fisheries Science Center/National Marine Mammal Laboratory, Seattle, WA. 45 pp.

North Pacific Fisheries Management Council. 2002. Fishery management plant for ground fish of the Gulf of Alaska. North Pacific Management Council, Anchorage, Alaska.

Overland, J. E. 1981. Marine climatology of the Bering Sea. In: D. W, Hood and J. A. Calder (eds.), The Eastern Bering Sea shelf: oceanography and resources, volume one. Published by the Office of Marine Pollution Assessment, National Oceanic and Atmospheric Administration and Bureau of Land Management, pp. 15-30.

Piatt, J.F. and A.M. Springer. 2007. Marine ecoregions of Alaska. Pp. 522-526 in: Spies, R.B. Longterm ecological change in the northern Gulf of Alaska. Elsevier B.V., Oxford, UK. 
Shulski, M. and G. Wendler. 2007. The Climate of Alaska. University of Alaska Press, Fairbanks. 216 pp.

Springer, A.M., C.P. McRoy, and M.V. Flint. 1996. The Bering Sea Green Belt: shelf-edge processes and ecosystem production. Fisheries and Oceanography 5:205-223.

Stabeno, P. J., J. D. Schumacher, and K. Ohtani. 1999. The physical oceanography of the Bering Sea: a summary of physical, chemical, and biological characteristics, and a synopsis of research on the Bering Sea. In: T. R. Loughlin and K. Ohtani (eds.) Dynamics of the Bering Sea. University of Alaska Sea Grant AK-SG-99-03, Fairbanks, Alaska. PP. 631-650.

Stabeno, P. J., N. A. Bond, N. B. Kachel, S. A. Salo, and J. D. Schumacher. 2008. On the temporal variability of the physical environment over the south-eastern Bering Sea. Fisheries Oceanography 10:81-98.

Stabeno, P. J., N. A. Bond, N. B. Kachel, S. A. Salo, J. D. Schumacher. 2001. On the temporal variability of the physical environment over the southeastern Bering Sea. Fisheries Oceanography 10:81-98.

Walsh, J. J., C. P. McRoy, L. K. Coachman, J. J. Georing, J. J. Nihoul, T. E. Whitledge, T. H. Blackburn, P. L. Parker, C. D. Wirick, P. G. Shuert, J. M. Grebmeier, A. M. Springer, R. D. Tripp, D. A. Hansell, S. Djenidi, E. Deleersnijder, K. Henricksen, B. A. Lund, P. Andersen, F. E. MullerKarger, and K. Dean. 1989. Carbon and nitrogen cycling with the Bering/Chukchi Seas: source regions for organic matter affecting AOU demands of the Arctic ocean. Progress in Oceanography 22:277-259.

Withrow, D. E. and T. R. Loughlin. 1995. Abundance and distribution of harbor seals (Phoca vitulina richardsi) along the north side of the Alaska Peninsula and Bristol Bay during 1995. In: Marine Mammal Protection Act and Endangered Species Act Implementation Program, 1995, National Marine Mammal Laboratory, National Marine Fisheries Service/NOAA, Seattle, WA. 


\section{Appendix 17. North Pacific Sea Marine Model}

\section{Geographic Context}

The marine area associated with the North Pacific Ecoregion is the northern Pacific Ocean from the Gulf of Alaska in the east to the Aleutian Islands. This area includes the Gulf of Alaska and part of the East Bering Sea PBCRs (fig. 8) and corresponds to marine ecoregions 1 through 13 (Piatt and Springer, 2007; table 3). It is fed by many small rivers in addition to the Susitna and Copper Rivers and is largely ice-free, except for periods each year in protected embayments and inlets.

The Aleutian Island Unit of Alaska Maritime NWR and Izembek NWR border both the North Pacific and the Bering Sea. The Gulf of Alaska Unit of Alaska Maritime NWR and Alaska Peninsula, Bechar of, Kodiak, and Kenai NWRs border only on the North Padific.

\section{Climate Overview}

In general, the climate is strongly maritime; high annual precipitation comes during frequent fall and winter storms, and the region typically has moderate temperatures and cloudy skies. Atmospheric and water circulation are driven by the Aleutian Low, a semi-permanent low pressure system occurring just south of the Aleutian Islands. It varies in strength on a decadal scale called the Pacific North American Oscillation, whose positive phase is associated with El Nino years of the El Nino/Southern Oscillation. Besides driving winds, it is also an area where eastward moving storms are intensified (Shulski and Wendler, 2007).

\section{Abiotic Processes and Components}

The continental shelf is 85 to $250 \mathrm{~km}$ wide along the south coast of Alaska and the Aleutian Islands, with the narrowest extent along the southeast Alaskan coast. As this is a subduction zone, the shelf drops to a depth of 4000 to 10,000 $\mathrm{m}$ in the Aleutian trench. Consequently, habitat and features of the North Pacific can be divided into coastal watersheds; intertidal and shallow subtidal areas; the Alaska Coastal Current, which extends up to $50 \mathrm{~km}$ from the coast; and offshore areas covered by the Alaska Stream, which include the continental shelf break, the continental slope and the deep ocean (GEM, 2002; fig. A17.1). The ocean floor and water column of these areas provide habitat for all trophic levels, as well as transport primarily for nutrients and plankton. Important characteristics include substrate; strength and direction of currents; frontal regions; eddies; water temperature; and salinity (Piatt and Springer, 2007). These determine the spatial and temporal patchiness of concentrations of biota.

The strength and direction of water flow is driven by wind resulting from cyclonic storms associated with the Aleutian Low, and results in counter-clockwise movement of the Alaska Gyre, the Alaskan Stream and the Alaska Coastal Current (ACC), which all exhibit greater strength in winter than in summer. The location of the Aleutian Low is influenced by global weather patterns manifest as the multi-year el-Nino/Southern Oscillation and the multi-decadal Pacific Decadal Oscillation (PDO). Under the positive phase of the PDO, flow of the ACC increases as does cross-shelf transport known as Ekman transport. These conditions favor salmon and some other large fish, while some seabirds, forage fish and shellfish are disadvantaged (GEM, 2002). 


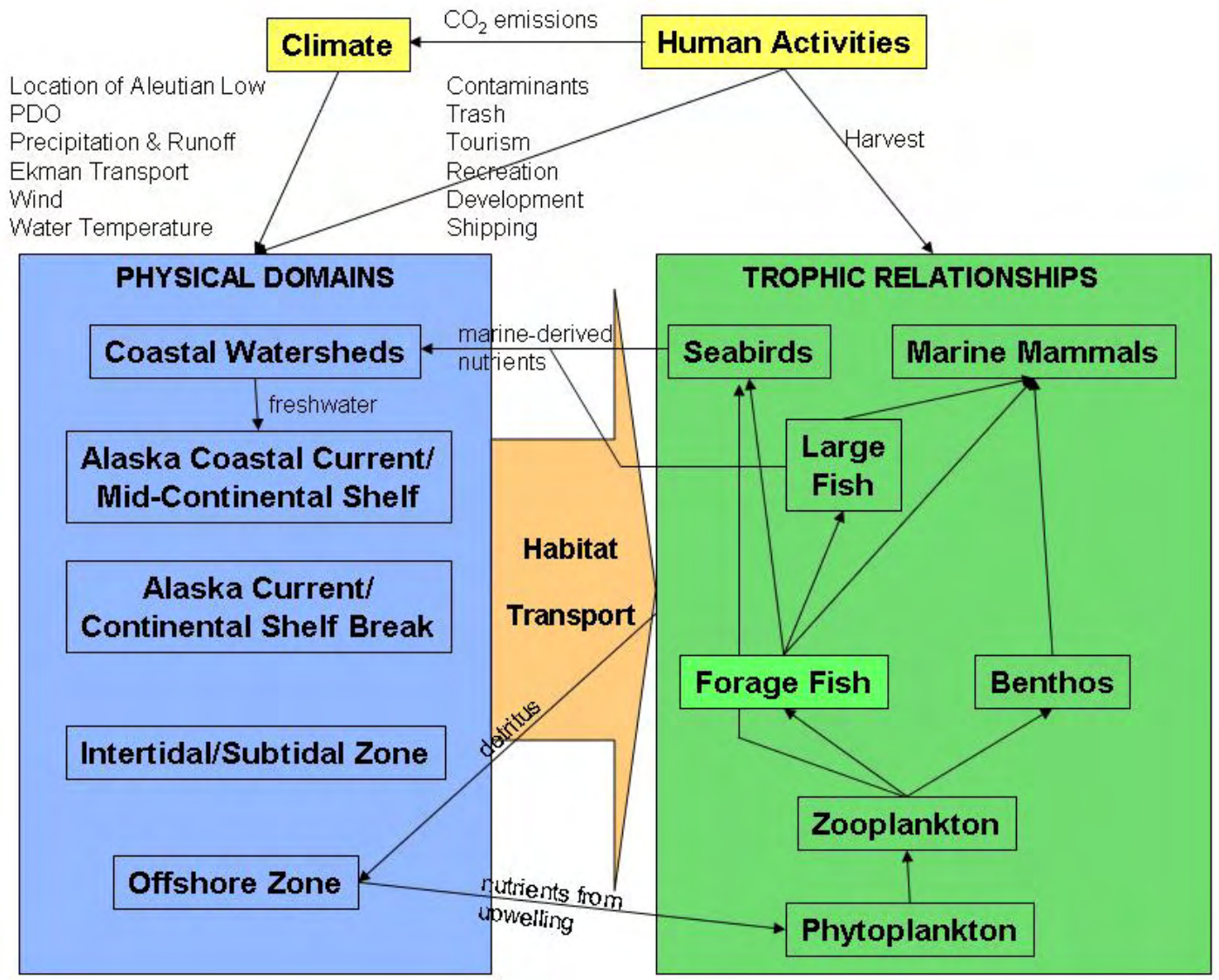

Figure A17.1. Conceptual model of the Gulf of Alaska marine ecoregion.

\section{Biotic Processes and Components}

Plankton production fuels the food web of the Gulf of Alaska, with the outcome depending on timing (Durbin and others, 1992; Pierson and others, 2005), which, in turn, depends of the phase of the PDO. During the cold phase, requirements for light, nutrients, and stable water conditions are met for a short period in the spring and early summer. Nutrients are supplied largely by upwelling of nutrients and inshore transport of plankton from offshore areas during winter storms. When storms abate in the spring, water stability increases and light is available. However, water stability due to calmer weather and freshwater flowing from coastal watersheds into the ACC restricts deeper, nutrient-carrying waters from mixing with the surface (GEM, 2002). Consequently, the plankton bloom quickly depletes available nutrients and fades, although another bloom is possible in the fall if upwelling from off-shore areas occurs when freshwater flow to the ACC slows during the late summer. This timing corresponds with larval production of shrimp, crabs and forage fish (e.g., capelin [Mallotus villosis]). These, in turn, support populations of piscivorous birds and marine mammals (Anderson and Piatt, 1999). 
During the warm phase of the PDO, warmer waters due to intensification of the Aleutian Low and consequent stronger westerly winds allows an earlier phyto- and zooplankton bloom. This timing favors recruitment of Pollock (Pollachius virens), halibut (Hippoglossus stenolepis) and other predatory fish over forage fish (Anderson and Piatt, 1999). The combination of poorer food supplies for larvae and greater predation by other fish may reduce the supply of forage fish for birds and mammals. Instead, they are forced to consume lower-quality diets such as juvenile pollock. However, the warm phase is advantageous for salmon, perhaps due to increased phyto- and zooplankton production (Anderson and Piatt, 1999).

In addition of the flow of freshwater and sediments, coastal watershed are linked to the ocean by the return of marine-derived nutrients. These are primarily carried by returning anadromous fish and enter the terrestrial system through consumption and decay of fish carcasses. Marine nutrients also are carried by seabirds and excreted in nesting area (GEM, 2002).

\section{References}

Anderson, P.J. and Piatt, J.F. 1999. Community reorganization in the Gulf of Alaska following ocean climate regime shift. Marine Ecology Progress Series 189:117-123.

Durbin, E.G., A.G. Durbin, and R.G. Campbell. 1992. Body size and egg production in the marine copepod Acartia hudsonica during a winter-spring diatom bloom in Narragansett Bay. Limnology and Oceanography 37:342-360.

Gulf of Alaska Ecosystem Monitoring and Research Program (GEM). 2002. The GEM Program Document. Exxon Valdez Oil Spill Trustee Council, Anchorage, Alaska.

Piatt, J.F. and A.M. Springer. 2007. Marine ecoregions of Alaska. Pp. 522-526 in: Spies, R.B. Longterm ecological change in the northern Gulf of Alaska. Elsevier B.V., Oxford, UK.

Pierson, J.J., C. Halsband-Lenk, and A.W. Leising. 2005. Reproductive success of Calanus pacificus during diatom blooms in Dabob Bay, Washington. Progress in Oceanography 67:314-331/

Shulski, M. and G. Wendler. 2007. The Climate of Alaska. University of Alaska Press, Fairbanks. 216 pp. 
This page left intentionally blank 
Publishing support provided by the U.S. Geological Survey Publishing Network, Tacoma Publishing Service Center

For more information concerning the research in this report, contact the Director, Alaska Science Center

U.S. Geological Survey

4210 University Dr.

Anchorage, Alaska 99508-4650

http://alaska.usgs.gov 
